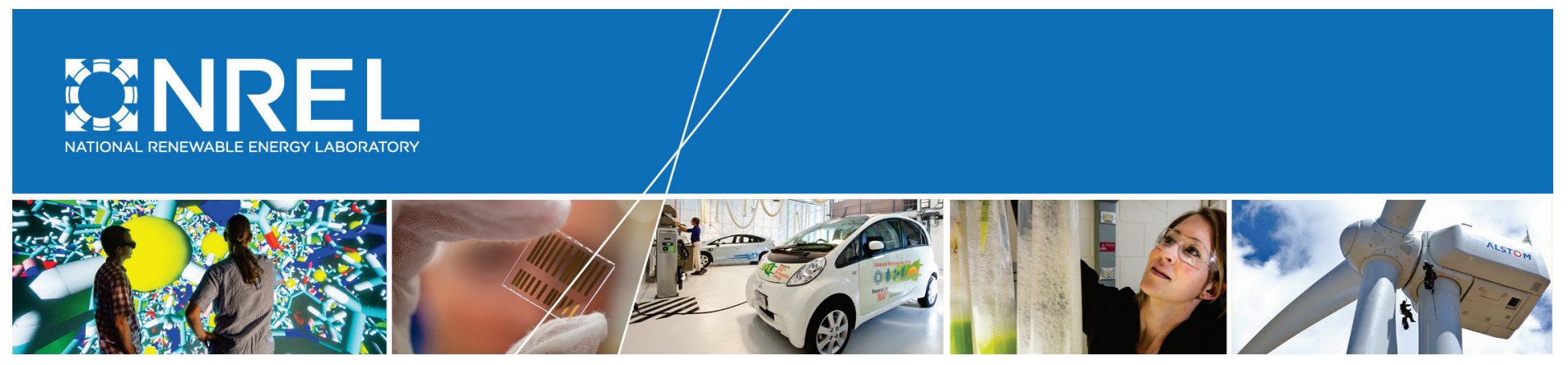

\title{
Marine Hydrokinetic Resource Assessment for Domestic Army, Air Force, and Coast Guard Facilities
}

Robi Robichaud and Michael R. Ingram National Renewable Energy Laboratory

NREL is a national laboratory of the U.S. Department of Energy Office of Energy Efficiency \& Renewable Energy Operated by the Alliance for Sustainable Energy, LLC

This report is available at no cost from the National Renewable Energy Laboratory (NREL) at www.nrel.gov/publications.

Technical Report

NREL/TP-5000-70519

April 2018 


\title{
Marine Hydrokinetic Resource Assessment for Domestic Army, Air Force, and Coast Guard Facilities
}

\author{
Robi Robichaud and Michael R. Ingram \\ National Renewable Energy Laboratory
}

\author{
Suggested Citation \\ Robichaud, Robi and M.R. Ingram. 2018. Marine Hydrokinetic Resource \\ Assessment for Domestic Army, Air Force, and Coast Guard Facilities. \\ Golden, CO: National Renewable Energy Laboratory. \\ NREL/TP-5000-70519. https://www.nrel.gov/docs/fy18osti/70519.pdf.
}

National Renewable Energy Laboratory 15013 Denver West Parkway Golden, CO 80401

303-275-3000 • www.nrel.gov
NREL is a national laboratory of the U.S. Department of Energy Office of Energy Efficiency \& Renewable Energy Operated by the Alliance for Sustainable Energy, LLC

This report is available at no cost from the National Renewable Energy Laboratory (NREL) at www.nrel.gov/publications.

\section{Technical Report}

NREL/TP-5000-70519

April 2018

Contract No. DE-AC36-08GO28308 


\section{NOTICE}

This report was prepared as an account of work sponsored by an agency of the United States government. Neither the United States government nor any agency thereof, nor any of their employees, makes any warranty, express or implied, or assumes any legal liability or responsibility for the accuracy, completeness, or usefulness of any information, apparatus, product, or process disclosed, or represents that its use would not infringe privately owned rights. Reference herein to any specific commercial product, process, or service by trade name, trademark, manufacturer, or otherwise does not necessarily constitute or imply its endorsement, recommendation, or favoring by the United States government or any agency thereof. The views and opinions of authors expressed herein do not necessarily state or reflect those of the United States government or any agency thereof.

This report is available at no cost from the National Renewable Energy Laboratory (NREL) at www.nrel.gov/publications.

Available electronically at SciTech Connect http:/www.osti.gov/scitech

Available for a processing fee to U.S. Department of Energy and its contractors, in paper, from:

U.S. Department of Energy

Office of Scientific and Technical Information

P.O. Box 62

Oak Ridge, TN 37831-0062

OSTI http://www.osti.gov

Phone: 865.576.8401

Fax: 865.576.5728

Email: reports@osti.gov

Available for sale to the public, in paper, from:

U.S. Department of Commerce

National Technical Information Service

5301 Shawnee Road

Alexandria, VA 22312

NTIS http://www.ntis.gov

Phone: 800.553 .6847 or 703.605 .6000

Fax: 703.605.6900

Email: orders@ntis.gov 


\section{Acknowledgments}

The U.S. Department of Energy (DOE) and the National Renewable Energy Laboratory (NREL) would like to thank the U.S. Coast Guard (USCG) and Sam Alvord, Chief. Office of Energy Management at USCG Headquarters; Commander Jason Biggar, Facilities Engineer, TRACEN Cape May; Kathleen Shilling, Chief, Engineering Branch, TRACEN Cape May; Ramiro Montes De Oca, Program Manager, Facility Operations at USCG; and Jesse Maestas, Verus Resource Management Inc., energy consultant to the USCG.

We would also like to thank the U.S. Army and Sarah Mandes, Renewable Energy Lead, DAIMODF; Tom Delaney, Energy Lead for the Army; John Kent, Energy Manager and Construction Coordinator, Army National Guard; Yona Baer, Master Planner, Massachusetts Army National Guard; Lieutenant Colonel David Shannon, Construction and Facility Management Officer; and Lieutenant Colonel Christopher Tatian, Army National Guard.

In addition, DOE and NREL would like to thank the U.S. Air Force and Daniel Gerdes, Energy Lead for the Air Force Civil Engineer Center, Energy Directorate Rates and Renewables Division, Tyndall Air Force Base; and Rafael Marquez, Air Force Civil Engineer Center Senior Renewable Energy Advisor.

NREL would like to thank Joel Cline and Steven DeWitt, Program Managers with DOE's Water Power Technologies Office (WPTO) for supporting this investigation and report, as well as for their participation and contributions fo the TRACEN Cape May site visit. NREL also thanks DOE's WPTO for funding this marine hydrokinetic resource and application investigation.

Michael Ingram, electrical engineer with NREL's utilities group, provided detailed analyses of the electrical interconnection potential at both the USCG's Cape May facility and the Army's Camp Edwards facility.

Jennifer Melius, NREL GIS specialist, provided the resource and data screening that were later translated into table and graphs.

Robi Robichaud, senior engineer at NREL, was the principal investigator and primary author for this report. 


\section{Nomenclature or List of Acronyms}

\begin{tabular}{|c|c|}
\hline $\mathrm{AFB}$ & Air Force Base \\
\hline AFCEC & Air Force Civil Engineer Center \\
\hline BOEM & Bureau of Ocean Energy Management \\
\hline CEC & Current Energy Conversion \\
\hline CFMO & Construction and Facility Management Officer \\
\hline COAWST & $\begin{array}{l}\text { Coupled-Ocean-Atmosphere-Wave-Sediment } \\
\text { Transport }\end{array}$ \\
\hline $\mathrm{COE}$ & Cost of Energy \\
\hline DHS & Department of Homeland Security \\
\hline DOD & United States Department of Defense \\
\hline DOE & Department of Energy \\
\hline EPRI & Electric Power Research Institute \\
\hline GIS & Geographic Information System \\
\hline GIT & Georgia Institute of Technology \\
\hline IEA & International Energy Administration \\
\hline KEF & Knowledge Encapsulation Framework \\
\hline kW & Kilowatt \\
\hline $\mathrm{kWh}$ & Kilowatt-Hour \\
\hline LCOE & Levelized Cost of Energy \\
\hline MaxTCS & Maximum Tidal Current Speed \\
\hline $\mathrm{MCBH}$ & Marine Corps Base Hawaii \\
\hline MeTCS & Mean Tidal Current Speed \\
\hline MHK & Marine Hydrokinetic \\
\hline MRE & Marine Renewable Energy \\
\hline MW & Megawatt \\
\hline MWh & Megawatt-Hour \\
\hline NAVFAC & Naval Facilities Engineering Command \\
\hline NEPA & National Environmental Policy Act \\
\hline NNREC & $\begin{array}{l}\text { Northwest National Marine Renewable Energy } \\
\text { Center }\end{array}$ \\
\hline NREL & National Renewable Energy Laboratory \\
\hline NOAA & National Oceanic and Atmospheric Administration \\
\hline NSWC & Naval Surface Warfare Center \\
\hline OES & Ocean Energy Systems \\
\hline ORNL & Oak Ridge National Laboratory \\
\hline PMEC & Pacific Marine Energy Center \\
\hline PNNL & Pacific Northwest National Laboratory \\
\hline RE & Renewable Energy \\
\hline ROMS & Regional Ocean Modeling System \\
\hline SRTM & Shuttle Radar Topography Mission \\
\hline TCS & Tidal Current Speed \\
\hline TRACEN Cape May & U.S. Coast Guard Training Center Cape May \\
\hline TWh & Terawatt-hour \\
\hline $\mathrm{TWh} / \mathrm{yr}$ & Terawatt-hour per year \\
\hline U.S. & United States \\
\hline
\end{tabular}


USAF

U.S. Coast Guard

USCG

USGS

WEC

WETS

WPD
United States Air Force

United States Coast Guard

United States Coast Guard

United States Geological Survey

Wave Energy Conversion

Wave Energy Test Site

Wave Power Density 


\section{Executive Summary}

The U.S. Department of Energy (DOE) has collaborated with the U.S. Departments of Defense (DOD) and Homeland Security (DHS) to investigate the potential for marine hydrokinetic (MHK) technologies to contribute to long-term agency renewable energy (RE), energy resiliency, and energy security goals. Both the DOD and DHS want to increase their energy resiliency and security to enhance their abilities to defend the nation and fulfill their broad-based missions. This study is intended to identify military and DHS sites with the greatest potential for MHK energy generation to serve base loads in the long term.

Presently, MHK technologies are largely considered pre-commercial in the U.S. power sector, with initial prototype technologies undergoing continued laboratory modeling, simulation, and benchtop testing augmented by extensive field testing. There are currently no commercially available MHK systems to meet base loads. For this reason, this assessment concentrates on longer-term deployment potential so that identified facilities can consider the future deployment of MHK technologies in their long-term base and energy development plans. Resources for MHK technologies include using the tide, wave, or current to generate electricity. This analysis focuses on larger-scale deployments of wave and tidal resources only.

Building on a previous MHK study completed for the U.S. Navy, Navy and Marine Corps Marine and Hydrokinetic Resource and Deployability Assessment, ${ }^{1}$ NREL researchers undertook a comparable study for DOD's Departments of the Army and Air Force, and DHS's U.S. Coast Guard (USCG). The study focused on the project development aspects of MHK technologies, overlaying the latest wave and tidal current resource data with project development considerations such as electrical infrastructure and environmental constraints to provide a comprehensive overview of MHK energy generation potential at individual bases. The intent of this study is to provide military and homeland security decision-makers with a realistic view of potential future technology options that can help meet their energy goals as MHK technologies become commercially viable.

NREL assessed on- and near-base wave and tidal resources and constraints using the methodology described in Section 4 and provided results showing locations where each type of MHK generation technology has the greatest potential, based on current data. The GIS analysis was augmented by utilizing the visual resource mapping tools of NREL's MHK Atlas ${ }^{2}$ to enhance discussions with the Army, Air Force, and Coast Guard renewable energy leads to down-select sites for further on-site investigation.

The U.S. Army National Guard's Camp Edwards in Bourne, MA, and the Coast Guard's Training Center Cape May (TRACEN Cape May) in Cape May, NJ, were down-selected for further resource analysis and on-site investigation.

The USCG conducted targeted and regional vessel traffic studies to further delineate the potential for both future MHK development as well as explore the suitability for development of a research and testing center. These studies pointed to several advantages for the potential tidal energy site near TRACEN Cape May off the southern tip of the Cape May Peninsula. Additionally, USCG

\footnotetext{
${ }^{1}$ Robichaud, R., Roberts, J., Parker, Z., Christol, C., Navy and Marine Corps Marine and Hydrokinetic Resource and Deployability Assessment, National Renewable Energy Laboratory Internal Report, 2015.

${ }^{2}$ NREL MHK Atlas, source: https://maps.nrel.gov/mhk-atlas/, accessed June 2016.
} 
considered the potential strategic benefits of enhanced energy resiliency and security to USCG operations across the mid-Atlantic region.

The selected sites were subjects of a more thorough resource modeling assessment performed by the Georgia Institute of Technology (GIT). GIT completed a site-specific numerical simulation performed with the Regional Ocean Modeling System (ROMS), embedded in the Coupled-OceanAtmosphere-Wave-Sediment Transport (COAWST) Modeling System. ${ }^{3}$ These studies resulted in high-resolution maps pointing to areas of highest tidal resource based on tidal flows and bathymetry. The analyses identified areas of specific interest, which served to greatly enhance the level of discussion topics during site visits. The Army, Coast Guard, DOE, and NREL conducted site visits in spring 2017 to better understand base operations and evaluate constraints that may affect potential MHK development/deployment opportunities.

Outcomes of the multiple levels of analyses and site visits include the USCG's interest in further exploring the potential to develop a tidal technology testing facility off the southern tip of Cape May. Another outcome is Camp Edwards' interest in incorporating the potential for MHK siting in long-range base plans as MHK technology develops with improved performance and decreased costs over time.

Overall, the uncertainty of estimating the potential deployability of a still-developing technology for time periods well into the future should be noted. Changes in any of the parameters used in the screening, such as a new electrical substation, can greatly affect the viability of a site. Similarly, a base's mission may change or undergo a significant increase or decrease in personnel and energy load.

As MHK technology develops, the cost of deploying these systems will decrease while reliability increases. Combined, these technological and economic developments may provide DOD and DHS with new ways to meet energy resiliency and security goals while increasing the overall sustainability of their operations.

\footnotetext{
${ }^{3}$ J. C. Warner, B. Armstrong, R. Y. He, and J. B. Zambon, "Development of a coupled ocean-atmosphere-wavesediment transport (COAWST) modeling system," Ocean Modelling. 35(3), 230-244 (2010).

https://doi.org/10.1016/j.ocemod.2010.07.010 .
} 


\section{Table of Contents}

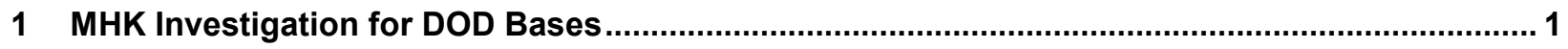

1.1 DOD Experience with MHK Technology and Testing ....................................................... 1

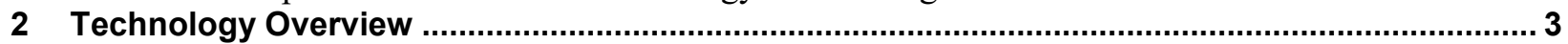

2.1 Wave Energy Converters Technology Description .............................................................. 3

2.2 Current Energy Converters Technology Description ............................................................... 4

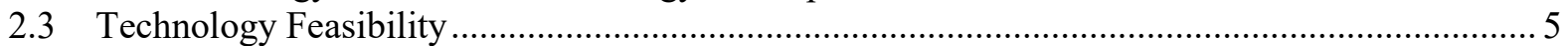

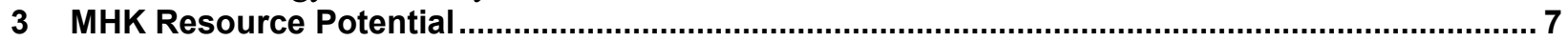

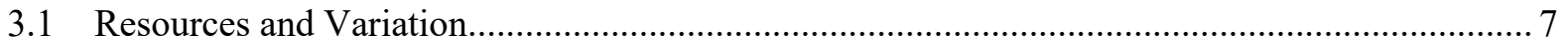

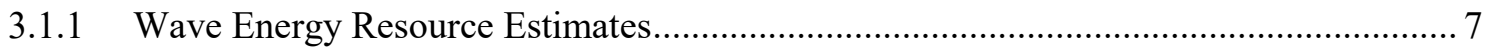

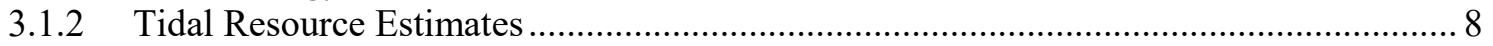

3.1.3 Ocean Current Resource Estimates ........................................................................... 9

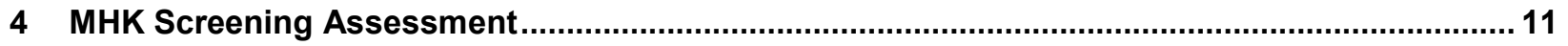

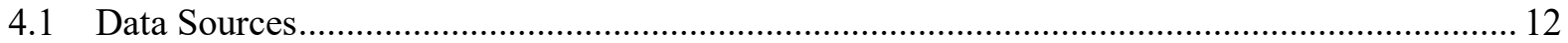

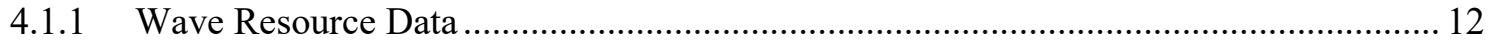

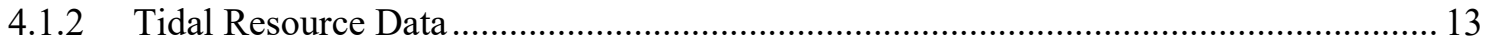

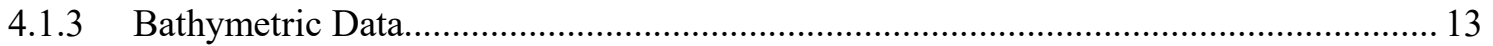

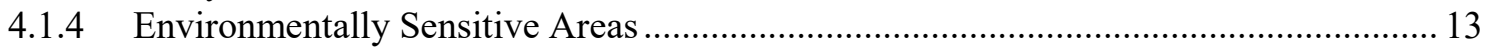

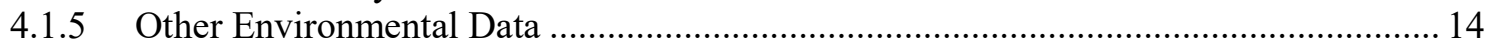

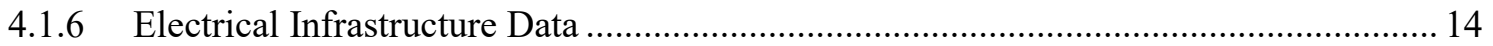

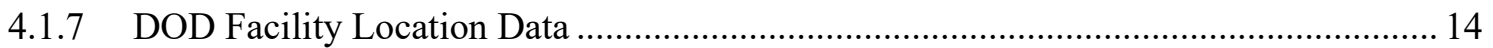

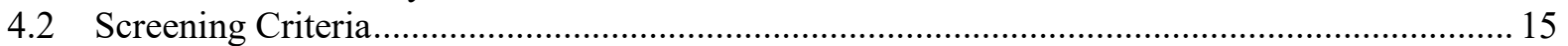

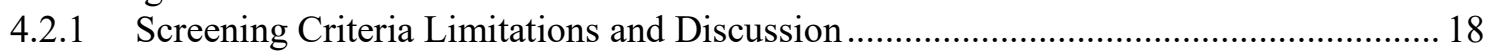

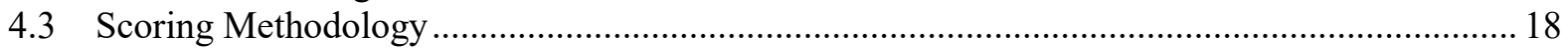

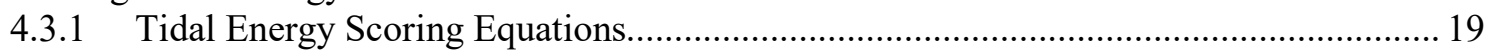

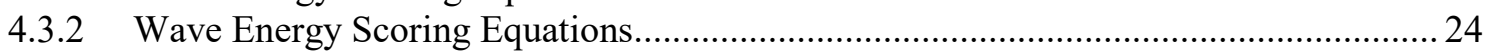

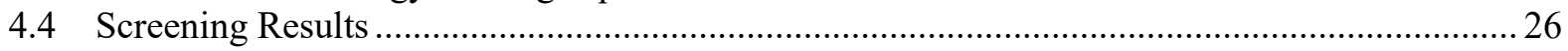

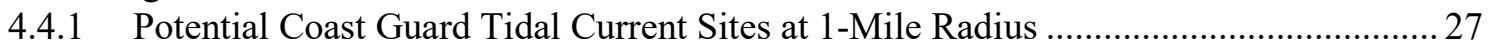

4.4.2 Potential Army Tidal Current Sites at 1-Mile Radius ................................................. 28

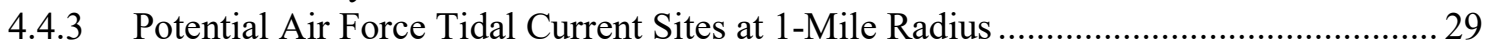

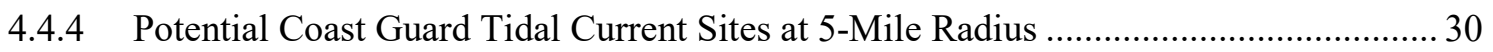

4.4.5 Potential Army Tidal Current Sites at 5-Mile Radius .................................................. 31

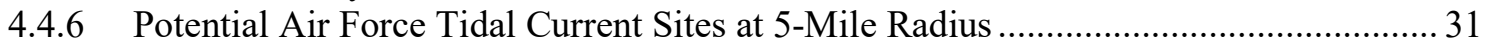

4.4.7 Potential Coast Guard Wave Energy Sites at 1-Mile Radius .......................................... 33

4.4.8 Potential Army Wave Energy Sites at 1-Mile Radius .................................................. 34

4.4.9 Potential Air Force Wave Energy Sites at 1-Mile Radius ............................................... 35

4.4.10 Potential Coast Guard Wave Energy Sites at 5-Mile Radius ........................................ 36

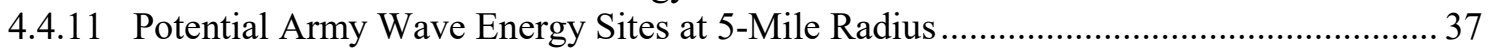

4.4.12 Potential Air Force Wave Energy Sites at 5-Mile Radius ............................................. 37

4.5 Down-Select from Screening Investigation................................................................... 39

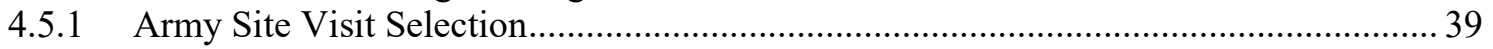

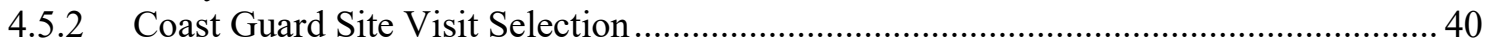

4.6 Cape May and Delaware Bay Vessel Traffic Study ….............................................................. 41

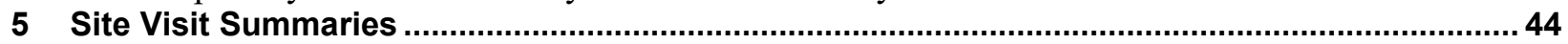

5.1 U.S. Coast Guard Training Center Cape May ..................................................................... 44

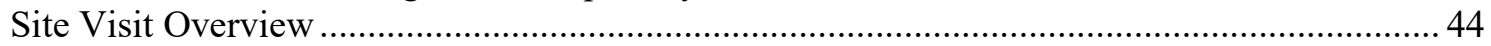

5.1.1 Cape May Electrical Infrastructure Investigation ........................................................ 45

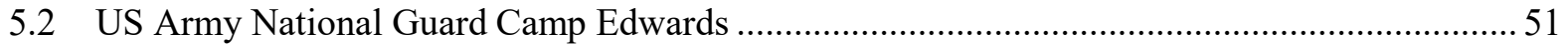

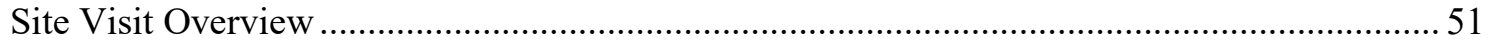

5.2.1 Camp Edwards Electrical Infrastructure Investigation................................................52 


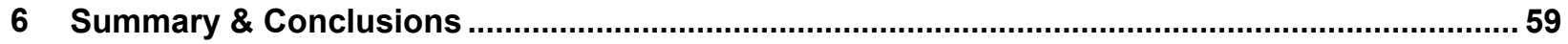

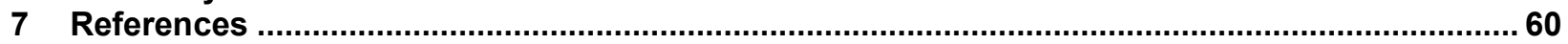

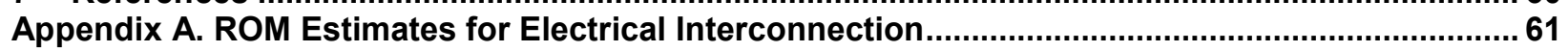

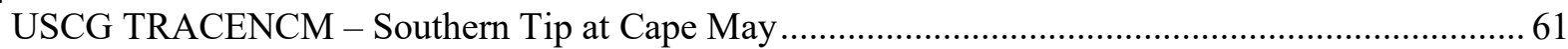

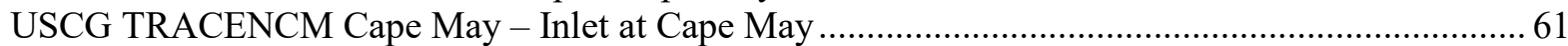

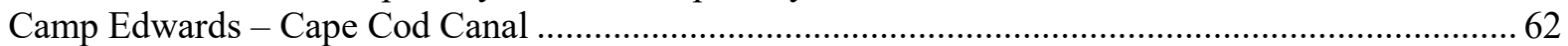

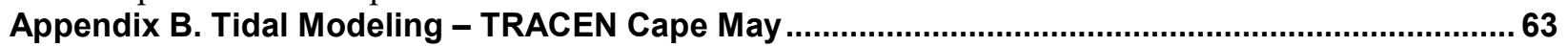

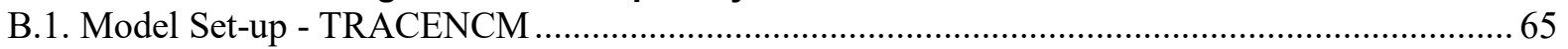

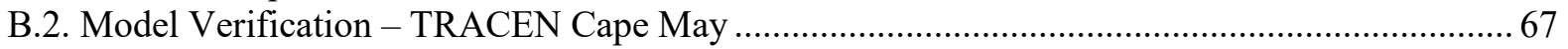

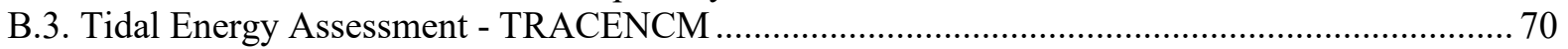

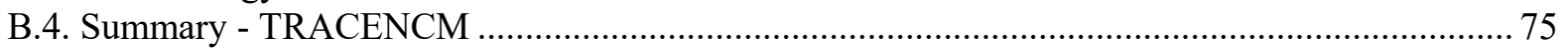

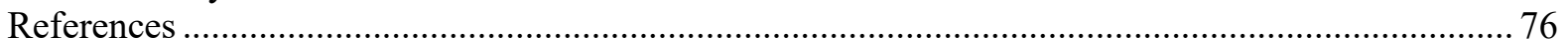

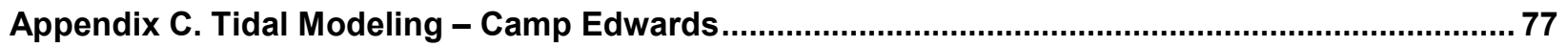

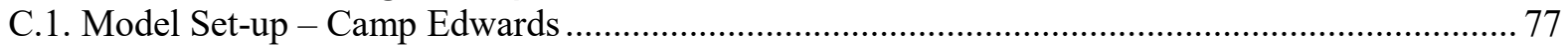

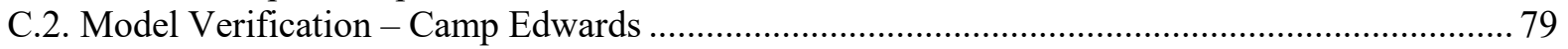

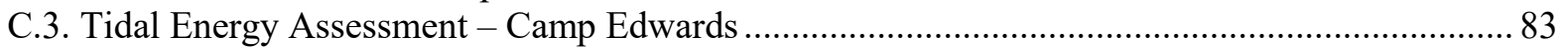

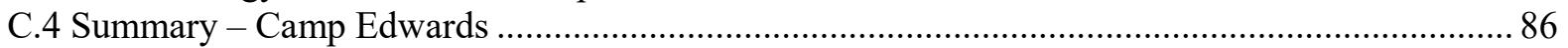

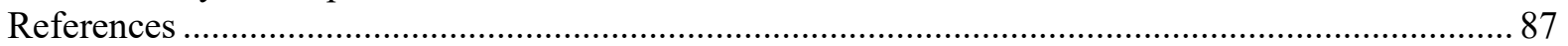

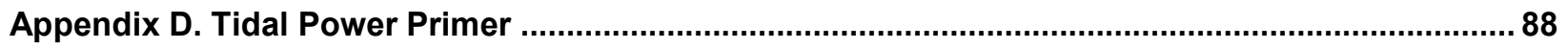

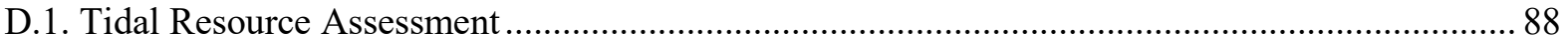

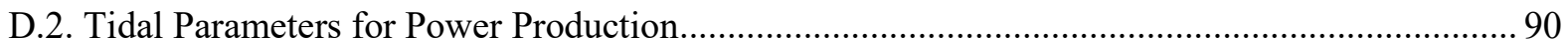

D.3. Bournedale Tidal Height and Period Assessment ................................................................. 91

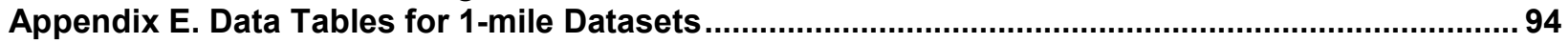




\section{List of Figures}

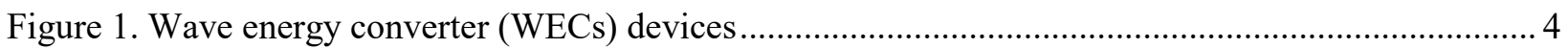

Figure 2. Vertical and horizontal tidal and ocean current turbines .................................................... 5

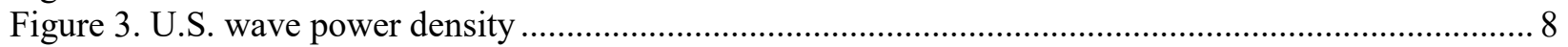

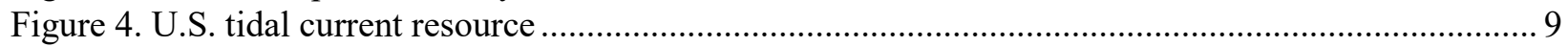

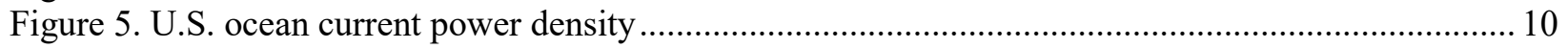

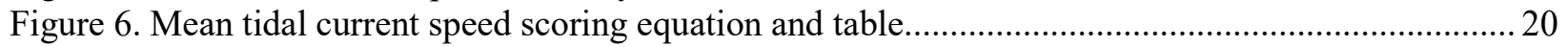

Figure 7. Ratio of maximum to mean tidal current speed scoring and table......................................... 20

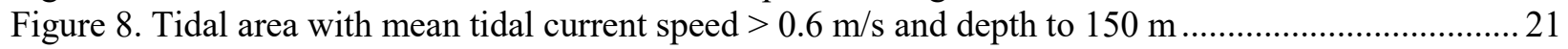

Figure 9. Distance to tidal resource scoring equation and table ......................................................... 21

Figure 10. Environmental and other exclusions scoring equation and table.......................................... 22

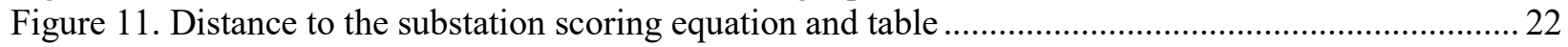

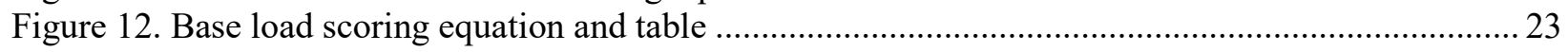

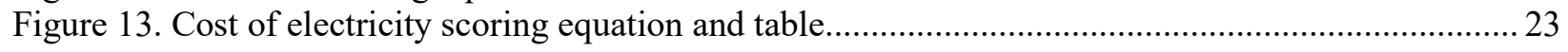

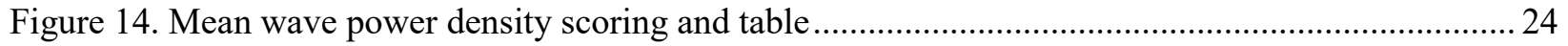

Figure 15. Ratio of maximum to mean wave power density scoring and table .......................................2

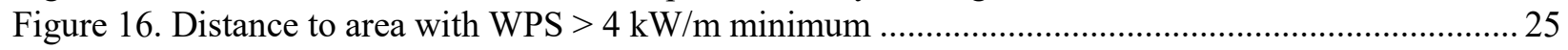

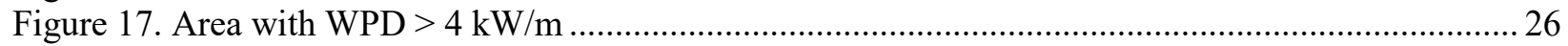

Figure 18. Annual tidal current speed in Cape Cod Canal near Camp Edwards ........................................ 39

Figure 19. Tidal current speed in the Delaware Bay and Cape May Inlet near Cape May........................ 40

Figure 20. Floating Vessel Traffic Study depicting traffic density likely in the vicinity of a potential tidal

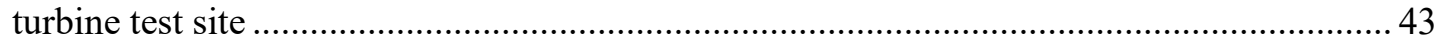

Figure 21. Regional map showing southern New Jersey, Cape May, and Delaware Bay ........................ 44

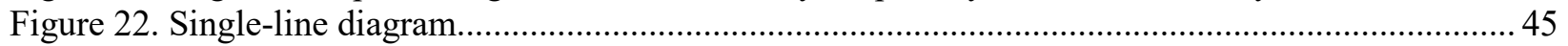

Figure 23. Typical electrical power transmission system from generator to substation transformer ......... 46

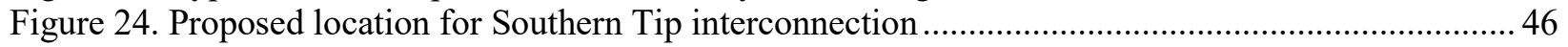

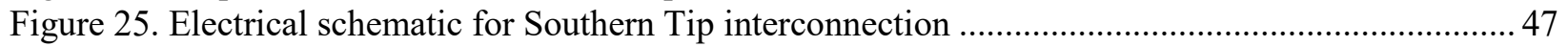

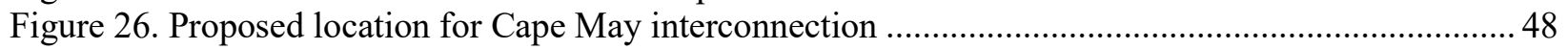

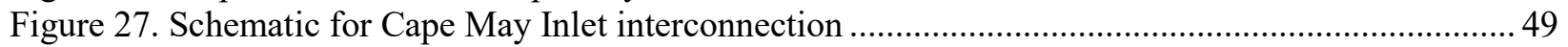

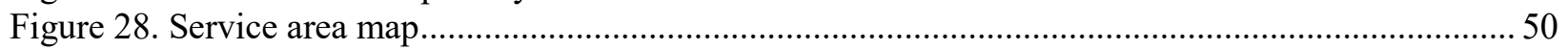

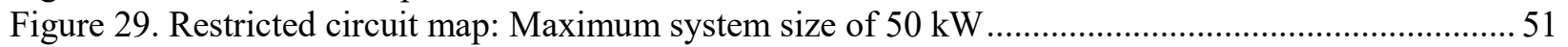

Figure 30. Overview map of Cape Cod, Joint Base Cape Cod and the surrounding waterways ............... 52

Figure 31. Single-line diagram for Camp Edwards .............................................................................. 53

Figure 32. Typical electrical power transmission system from generator to substation transformer ......... 54

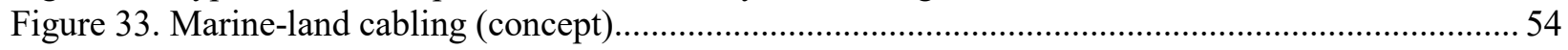

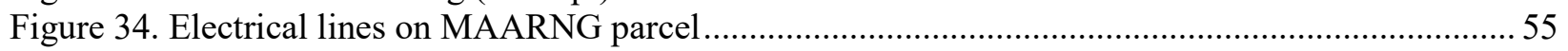

Figure 35. Proposed new circuit connecting "Area of Interest" to Camp Delivery-point.......................... 56

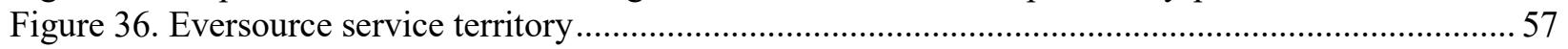

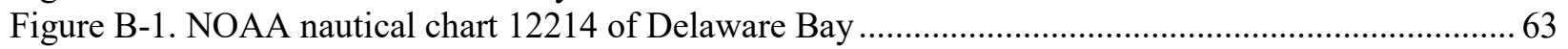

Figure B-2. Zoomed-in NOAA nautical chart 20114 for the southern tip of Cape May .......................... 64

Figure B-3. Maps of interested areas highlighted in red: (a) Delaware Bay in the scope of the U.S. east coast; (b) U.S Coast Guard Station at Cape May, New Jersey ............................................ 64

Figure B-4. Model bathymetry of the coarser (parent) grid. Red rectangle marks the region for the refined (child) grid.

Figure B-5. (a) Model bathymetry of the refined grid. Green and red rectangles outline the two regions of interest. Zoom-in bathymetry of (b) the Cape May Harbor and (c) the Southern Tip of Cape

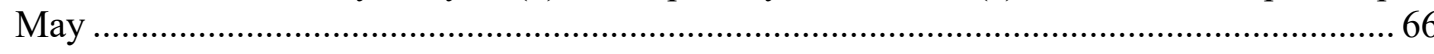

Figure B-6. Model bathymetry of the refined grid. Stars with edge color in red mark locations of tidal harmonic data. Stars with edge color in black mark locations of current stations. Zoom in view of the bathymetry helps clarify the location of the Station CAM0001. 
Figure B-7. Depth averaged current speed from the refined grid

Figure B-8. Zoom-in view of the depth averaged current speed for Cape May Harbor. Triangle marks the location for evaluating AEP density....

Figure B-9. Zoom-in view of the depth averaged current speed for the Southern Tip of Cape May.

Triangle marks the location for evaluating AEP density.

Figure B-10. Maximum depth averaged current speed from the refined grid.....

Figure B-11. Zoom-in view of the maximum depth averaged current speed for Cape May Harbor .......... 72

Figure B-12. Zoom-in view of the maximum depth averaged current speed for the Southern Tip of Cape May

Figure B-13. Histogram of depth averaged current velocity magnitudes for (a) Cape May Inlet and

(b) the southern tip of Cape May

Figure B-14. Joint PDF of velocity and direction for (a) Cape May Inlet and (b) Southern Tip of Cape May 74

Figure B-15. Exceedance curve for current speed at Cape May Inlet and southern tip......................... 75

Figure C-1. NOAA nautical chart 13229 of the Cape Cod Canal area .................................................... 77

Figure C-2. Maps of areas of interest highlighted in red: (a) Cape Cod in the scope of the U.S. east coast

(b) Camp Edwards, Massachusetts

Figure C-3. Model bathymetry of the Cape Cod Canal. Zoom-in view enlarges the region adjacent to Camp Edwards. Triangles mark the locations of water level stations used for tidal forcing in ROMS.

Figure C-4. Model bathymetry of the Cape Cod Canal. Red stars red mark locations of tidal harmonic data. Black stars mark locations of current stations.

Figure C-5. Depth-averaged current speed. Zoom-in view shows the depth-averaged current speed for the region adjacent to Camp Edwards. The blue dot marks the location of Station COD0902 for evaluating AEP density.

Figure C-6. Maximum depth-averaged current speed. Zoom-in view shows the maximum depthaveraged current speed for the region adjacent to Camp Edwards .84

Figure C-7. Histogram of depth-averaged current velocity magnitudes for Station COD0902 ................ 85

Figure C-8. Joint probability distribution of velocity and direction for Station COD0902 .......................85

Figure C-9. Exceedance curve for current speed at Station COD0902 …............................................. 86

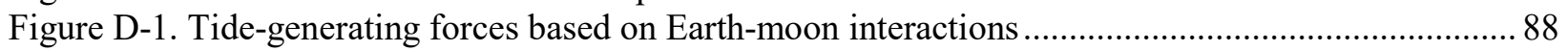

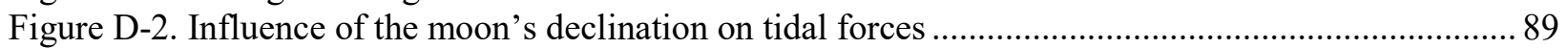

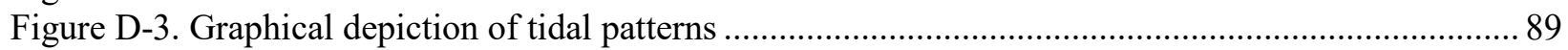

Figure D-4. Phases of the moon and resultant lunar and solar spring and neap tides .............................. 90

Figure D-5. Sample tidal current speed distribution .......................................................................... 91

Figure D-6. Sample turbine output power versus flow speed .............................................................. 91

Figure D-7. Bournedale, Cape Cod Canal tide level per mean lower low water level: seven-day profile . 92

Figure D-8. Bournedale, Cape Cod Canal tide level per mean lower low water level: 30-day profile....... 93 


\section{List of Tables}

Table 1. Total Available Wave Energy Resource............................................................................... 13

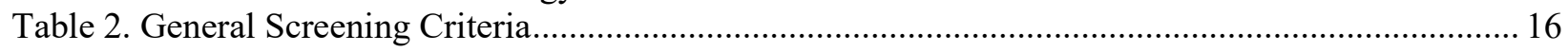

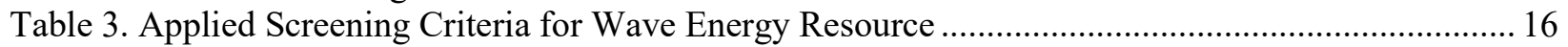

Table 4. Applied Screening Criteria for Tidal Current Resource .......................................................... 16

Table 5. 1- and 5-mile Environmental Constraints Applied in Initial Screening ..................................... 17

Table 6. 1- and 5-mile Infrastructure Constraints Applied in Initial Screening....................................... 17

Table 7. Coast Guard Sites with High Potential for Tidal Current MHK Projects at 1-Mile Radius ......... 27

Table 8. Army Sites with High Potential for Tidal Current MHK Projects at 1-Mile Radius .................... 28

Table 9. Air Force Sites with High Potential for Tidal Current MHK Projects at 1-Mile Radius ............. 29

Table 10. Coast Guard Sites with High Potential for Tidal Current MHK Projects at 5-Mile Radius ....... 30

Table 11. Army Guard Sites with High Potential for Tidal Current MHK Projects at 5-Mile Radius ....... 31

Table 12. Air Force Sites with High Potential for Tidal Current MHK Projects at 5-Mile Radius ............ 32

Table 13. Coast Guard Sites with High Potential for Wave Energy MHK Projects at 1-Mile Radius ....... 33

Table 14. Army Sites with High Potential for Wave Energy MHK Projects at 1-Mile Radius.................. 34

Table 15. Air Force Sites with High Potential for Wave Energy MHK Projects at 1-Mile Radius............ 35

Table 16. Coast Guard Sites with High Potential for Wave Energy MHK Projects at 5-Mile Radius ....... 36

Table 17. Army Sites with High Potential for Wave Energy MHK Projects at 5-Mile Radius.................. 37

Table 18. Air Force Sites with High Potential for Wave Energy MHK Projects at 5-Mile Radius............. 38

Table A-1. Rough Order of Magnitude (ROM) Estimate for Southern Tip Interconnection .................... 61

Table A-2. Rough Order of Magnitude (ROM) Estimate for Cape May Inlet Interconnection................. 61

Table A-3. Rough Order of Magnitude (ROM) Estimate for Cape Cod Canal Interconnection ................ 62

Table C-1. Verification of tidal water level harmonic constituents for Station

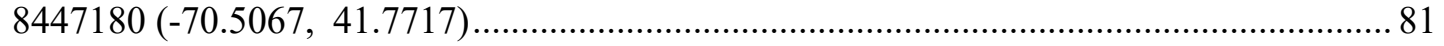

Table C-2. Verification of tidal water level harmonic constituents for Station

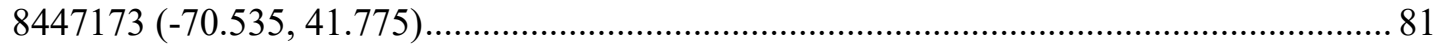

Table C-3. Verification of tidal water level harmonic constituents for Station

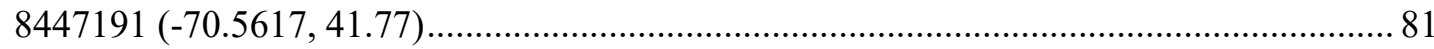

Table C-4. Verification of tidal water level harmonic constituents for Station

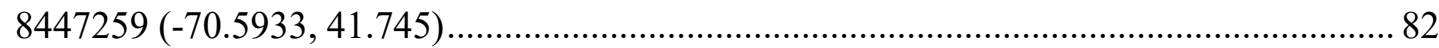

Table C-5. Verification of tidal water level harmonic constituents for Station

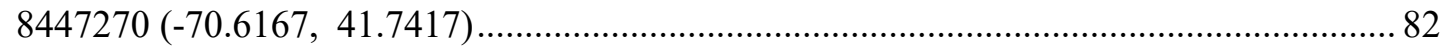

Table C-6. Verification of tidal current harmonic constituents for Station

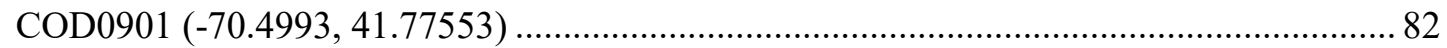

Table C-7. Verification of tidal current harmonic constituents for Station

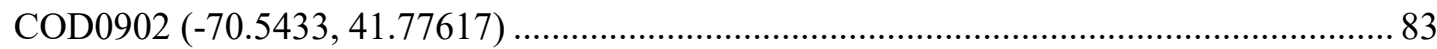

Table C-8. Verification of tidal current harmonic constituents for Station

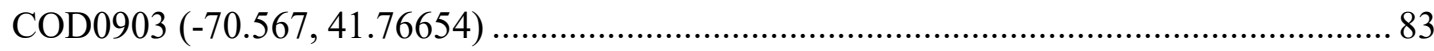

Table E-1. Coast Guard Sites with High Potential for Tidal Current MHK Projects

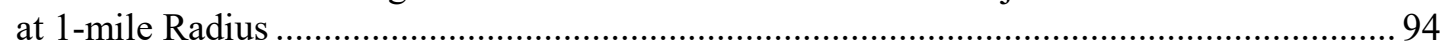

Table E-2. Scoring for Coast Guard Sites with High Potential for Tidal Current MHK Projects

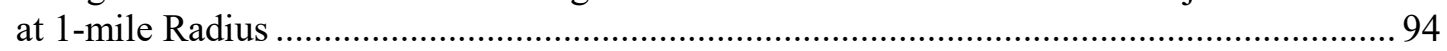

Table E-3. U.S. Army Sites with High Potential for Tidal Current MHK Projects at 1-mile Radius......... 95

Table E-4. Scoring for U.S. Army Sites with High Potential for Tidal Current MHK Projects at 1-mile Radius

Table E-5. U.S. Air Force Sites with High Potential for Tidal Current MHK Projects at 1-mile Radius

Table E-6. Scoring for U.S. Air Force Sites with High Potential for Tidal Current MHK Projects at 1-mile Radius 96 
Table E-7. U.S. Coast Guard Sites with High Potential for Wave Energy MHK Projects at 1-mile Radius

Table E-8. Scoring for U.S. Coast Guard Sites with High Potential for Wave Energy MHK Projects at 1-mile Radius 97

Table E-9. U.S. Army Sites with High Potential for Wave Energy MHK Projects at 1-mile Radius

Table E-10. Scoring for U.S. Army Sites with High Potential for Wave Energy MHK Projects at 1-mile Radius

Table E-11. U.S. Air Force Sites with High Potential for Wave Energy MHK Projects at 1-mile Radius 100

Table E-12. Scoring for U.S. Air Force Sites with High Potential for Wave Energy MHK Projects at 1-mile Radius 100 


\section{MHK Investigation for DOD Bases}

The U.S. Department of Energy (DOE) has collaborated with the U.S. Departments of Defense (DOD) and Homeland Security (DHS) to investigate the potential for marine hydrokinetic (MHK) technologies to contribute to long-term agency renewable energy (RE), energy resiliency, and energy security goals. Both the DOD and DHS want to increase their energy resiliency and security to enhance their abilities to defend the nation and fulfill their broad-based missions. This study is intended to identify military and DHS sites with the greatest potential for energy generation to serve base loads from MHK in the long term.

The National Renewable Energy Laboratory (NREL) completed an MHK assessment study, Navy and Marine Corps Marine and Hydrokinetic Resource and Deployability Assessment, ${ }^{4}$ for Naval Facilities Engineering Command (NAVFAC) in Fiscal Year 2015 that examined the full suite of domestic Navy and Marine bases and their nearby wave, tidal, and ocean current resources. Extensive screening by NAVFAC and NREL, enhanced by a scoring algorithm developed by NREL, served to narrow the field to seven bases for on-the-ground site visits. Two bases were down-selected for in-depth bathymetric and resource modeling studies conducted by the Georgia Institute of Technology (GIT).

The DOE, in partnership with the DOD and DHS, extended the parameters of the Navy MHK study to include the Departments of the Army, Air Force, and DHS's U.S. Coast Guard (USCG) in a new study, documented in this report. The study aimed to improve scoring algorithms and mechanisms to provide an initial framework for site comparison as MHK technologies continue to evolve and progress toward commercially viable RE generation devices.

\subsection{DOD Experience with MHK Technology and Testing}

DOD has been involved with MHK technology testing in several capacities. Several of these activities are ongoing. A brief synopsis includes the following:

- U.S. Navy Wave Energy Test Site (WETS) located at Marine Corps Base Hawaii at Kaneohe (MCBH). The facility has three-point moorings at 30-m, 60-m, and 80-m depths; power cables; extensive wave resource characterization; and data cables. ${ }^{5}$ WETS has partnered with DOE, University of Hawaii, and others to develop a multi-function test site that has tested both point-absorber and oscillating water-column MHK devices.

- Camp Rilea MHK (wave) Testing Facility at the training center for armed forces located on the northwest coast of Oregon. The Oregon National Guard has been pursuing MHK technology as a means of furthering its net-zero energy initiative, a plan for becoming energy independent. The Northwest National Marine Renewable Energy Center (NNMREC) has partnered with Camp Rilea to support MHK testing. ${ }^{6}$ Oregon State University signed a memorandum of understanding (MOU) with the Oregon Military Department as a formal demonstration of NNMREC partnering to support wave energy converter (WEC) testing at the Camp Rilea facility. Camp Rilea provides an ideal testing

\footnotetext{
${ }^{4}$ Robichaud, R., Roberts, J., Parker, Z., Christol, C., Navy and Marine Corps Marine and Hydrokinetic Resource and Deployability Assessment, National Renewable Energy Laboratory Internal Report, 2015.

${ }^{5}$ Vega, L., University of Hawaii, US Navy Wave Energy Test Site Kaneohe, HI. Web source: http://hinmrec.hnei.hawaii.edu/wp-content/uploads/2009/12/WETS_Sep-2014.pdf. Accessed May 2017.

${ }^{6}$ Web source: http://nnmrec.oregonstate.edu/announcement/nnmrec-partners-support-testing-camp-rilea. Accessed May 2017.
} 
location for shallow- and mid-depth WECs and is a great complement to the Pacific Marine Energy Center (PMEC) testing sites.

- Naval Surface Warfare Center (NSWC) Carderock Division ${ }^{7}$ (facilities located across the United States) is the Navy's state-of-the-art research, engineering, modeling, and test center for ships and ship systems. It is the largest, most comprehensive establishment of its kind in the world, serving a dual role in support of both our U.S. naval forces and the maritime industry. Within its Power and Energy division, the Navy investigates Alternative Energy and Power Sources Research and Development with the intent of developing advanced platforms and systems, enhancing naval performance, reducing operating costs and addressing the Navy's evolving mission.

${ }^{7}$ Web source: http://www.navsea.navy.mil/Home/Warfare-Centers/NSWC-Carderock/. Accessed Mays 2017 


\section{Technology Overview}

Presently, MHK technologies are largely considered pre-commercial in the U.S. power sector, with creative prototype technologies undergoing extensive design modelling and initial field testing. For this reason, this assessment concentrates on longer-term deployment potential so that identified facilities can consider the future deployment of MHK technologies in their long-term base and energy development plans. Resources for MHK technologies include using the tide, wave, or ocean current to generate electricity. This analysis focuses on larger-scale deployments of wave and tidal energy converting devices only as these are viewed as having the necessary long-term potential within proximity of DOD bases. As wave and tidal energy technologies become more cost effective and reliable, it is envisioned that both will play a significant role in on-site energy generation for large DOD bases.

Marine hydrokinetic technologies considered in this report are separated into two categories: wave energy converters (WECs) and current energy converters (CECs). These technologies capture and convert energy available from ocean waves, ocean current, and ocean tides with very different energy-capture features and electrical generation architectures.

\subsection{Wave Energy Converters Technology Description}

WECs extract energy contained within ocean surface waves or from pressure fluctuations below the surface. The primary categories of WECs are point absorbers, terminators, attenuators, overtopping devices, and oscillating water columns (Figure 1). The figure shows representations of the types of devices, although individual manufacturers exhibit considerable variation within WEC prototype designs. The DOE has sponsored the Wave Energy Prize Competition (two phases in FY17 and FY18-19) to encourage innovative thinking and creative design enhancements to foster prototype development with a goal to double WEC's energy capture thereby reducing the cost of energy and increasing competitiveness with other generating technologies.

Point absorbers extract energy through heaving and pitching motions and are small with respect to the wavelength of the oncoming waves. Terminators are oriented with their dominant dimension perpendicular to incoming waves and can theoretically absorb $100 \%$ of the incoming wave energy. Attenuators are oriented with their dominant dimension parallel to incoming waves and captures energy along its length from the length of the incoming wave. Overtopping devices, which operate as terminators, gather water in a reservoir higher than the mean water surface and use the pressure difference to drive a turbine. Oscillating water-column devices use an air turbine that is driven by water levels moving air into and out of a pressurized chamber. The sketches in Figure 1 below illustrate common configurations of these technology approaches. 

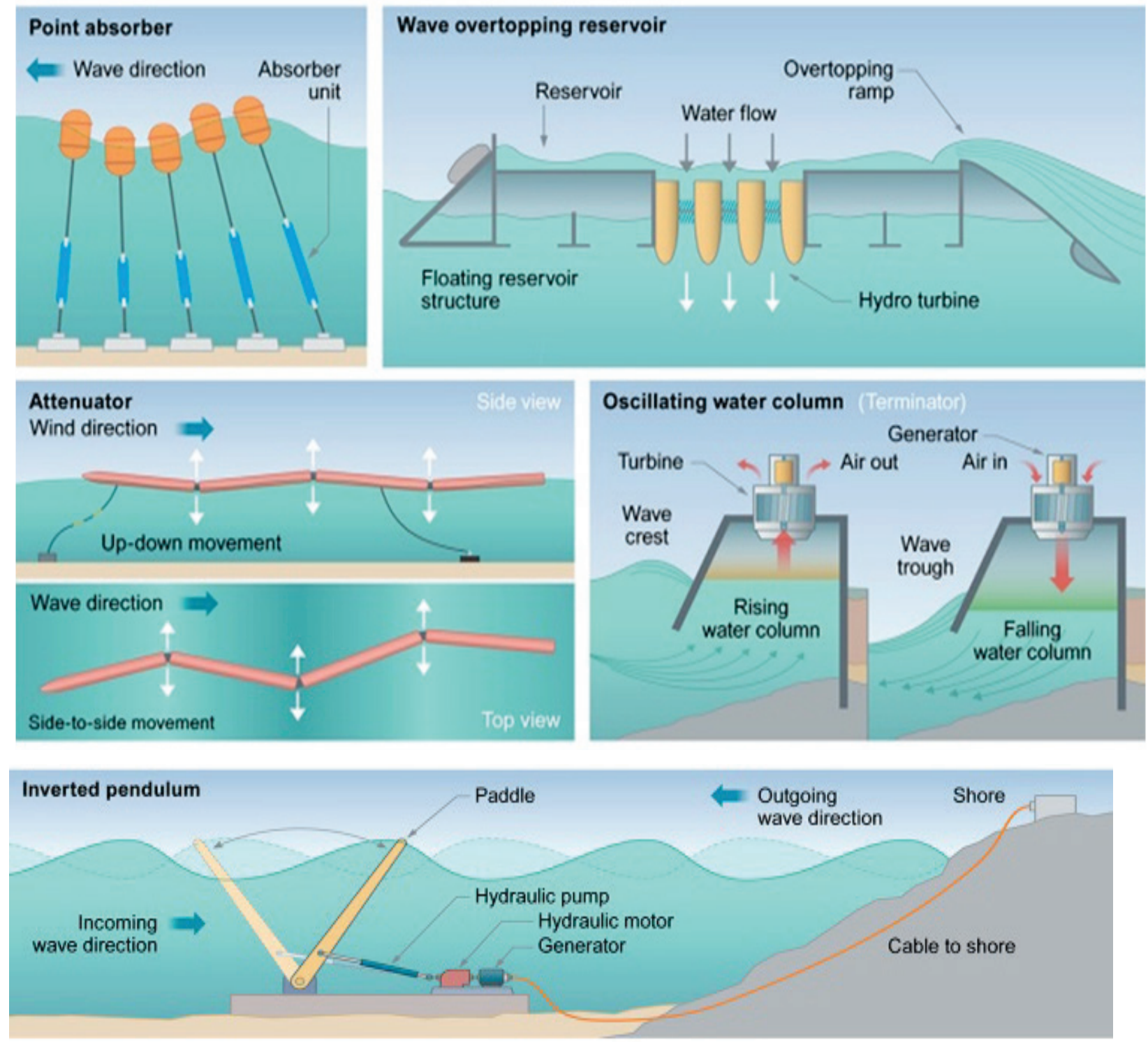

Figure 1. Wave energy converter (WECs) devices

Source: Augustine et al. 2012

\subsection{Current Energy Converters Technology Description}

CECs extract energy from ocean, tidal, and river currents. These devices are significantly more advanced than WECs as some resemble wind turbines adapted to the marine environment and draw on decades of research and development experience from the wind energy industry (upper left drawing in Figure 2). There are currently CECs available in the marketplace as a commercial, though more expensive, electric generation technology. In some countries, CECs are beginning to bridge the gap from prototype testing to more commercial-type applications. Like wind turbines, CECs can be deployed in arrays to maximize energy capture. Some of the more common technology approaches are illustrated in Figure 2 below. 

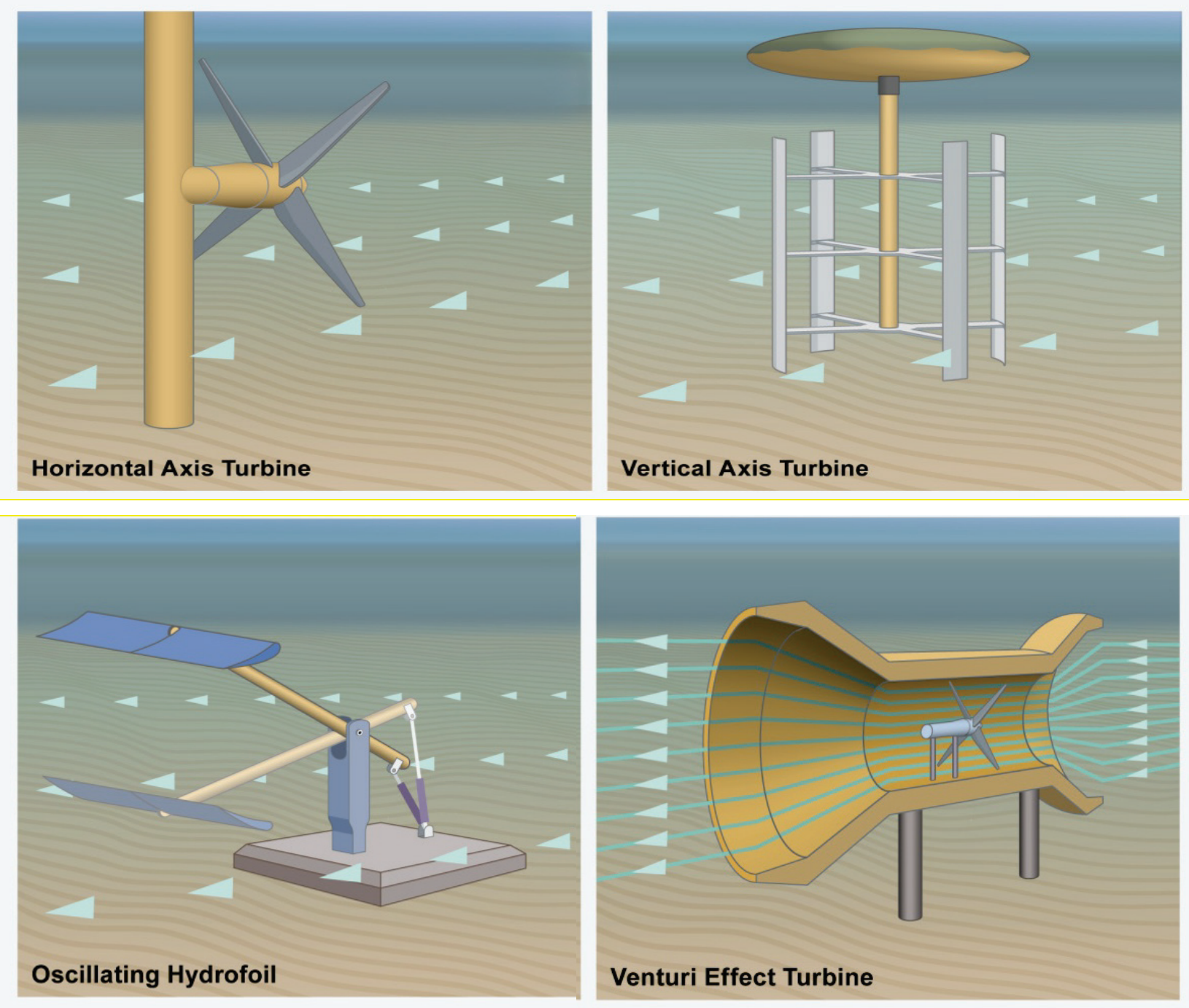

Figure 2. Vertical and horizontal tidal and ocean current turbines ${ }^{8}$

\subsection{Technology Feasibility}

WECs require unique configurations that do not resemble other existing commercial energy generation technologies. As such, WECs are still a developing technology and not yet economically viable or commercially deployed. Various device concepts and prototypes have been deployed in test scenarios in ongoing efforts to develop a commercially viable technology. The report Levelized Cost of Energy Analysis of Marine and Hydrokinetic Reference Models ${ }^{9}$ estimates the levelized cost of energy (LCOE) for early arrays at \$0.69-1.06/kWh at a 100 -unit scale.

\footnotetext{
${ }^{8}$ Hand, M.M.; Baldwin, S.; DeMeo, E.; Reilly, J.M.; Mai, T.; Arent, D.; Porro, G.; Meshek, M.; Sandor, D. eds. 4 vols. Renewable Electricity Futures Study. (2012). NREL/TP-6A20-52409. Golden, CO: National Renewable Energy Laboratory. http://www.nrel.gov/analysis/re futures/.

${ }^{9}$ Jenne, D.S., Yu, Y.-H., Neary, V. Third Marine Energy Technology Symposium conference paper, Washington D.C. April 2015.
} 
Commercial-scale CECs have been successfully deployed in the United States. Recent estimates indicate that the current generation of CEC devices has a LCOE of $\$ 0.15-0.35 / \mathrm{kWh}^{10}$ at a 100 -unit scale. As more commercial devices and arrays are installed and operated, industry learning and innovation are expected to drive cost improvements and yield a reduction in LCOE. The Carbon Trust estimates that if $100 \mathrm{MW}$ of CEC capacity is installed globally, industry experience will result in a $39 \%$ reduction in LCOE. ${ }^{11}$

For tidal energy devices, the MayGen project in Pentland Firth off the coast of Scotland has recently been initiated as a commercial venture with a strike price of $£ 305 / \mathrm{MWh}^{12}$ (British pounds;

$\$ 495 / \mathrm{MWh}$ equivalent). Other tidal energy research, by Ocean Energy Systems, ${ }^{13}$ estimates early array costs for tidal energy devices at $\$ 0.13-0.28 / \mathrm{kWh}$ at a 3-90 MW scale.

With all these MHK technologies, there is widespread agreement that the technologies are not yet near the bottom of the cost curve at this time and that costs will continue to decrease as designs improve, more durable and less costly materials are developed, and efficiencies increase.

\footnotetext{
${ }^{10}$ Jenne et al, ibid.

${ }^{11}$ Carbon Trust, “Accelerating Marine Energy,” Carbon Trust, July 2011.

${ }^{12}$ Carbon Trust, “Accelerating Marine Energy," Carbon Trust, July 2011.

${ }^{13}$ Ocean Energy Systems, "International Levelised Cost of Energy for Ocean Energy Technologies," May 2015.
} 


\section{MHK Resource Potential}

Historical records of environmental parameters are used to characterize the available energy resource for MHK technologies. WECs require an historical time series of wave height. CECs rely on a velocity-field time series. The measured parameters are used to determine the potential kinetic energy available in kilowatt-hours per year $(\mathrm{kWh} / \mathrm{yr})$ or the kinetic power density in kilowatts per square meter $\left(\mathrm{kW} / \mathrm{m}^{2}\right)$ at a given location. For large areas involving the sum or average of many locations, a more convenient scale for kinetic energy availability is terawatt-hours per year (TWh/yr). The technically recoverable energy shares the same units and depends on the efficiency and size of MHK devices themselves, as well as the definition of areas that are excluded from development due to environmental considerations and usage constraints.

\subsection{Resources and Variation}

The total available resource illustrates the potential for MHK technology deployment in U.S. waters. Each of the types of resources — wave, tidal, and ocean current — vary considerably by geographic location, magnitude and range of resource, optimal depths for resource use, and seasonal and diurnal variation.

When MHK technologies get to the commercial full-scale deployment stage, it is expected that detailed resource assessments would be undertaken as part of a comprehensive energy supply and use strategy accounting for diurnal and seasonal resource fluctuations and integrating those with other on-site energy sources, storage, and the grid.

For purposes of this report, annual mean values of the tidal or wave resource are sufficient.

\subsubsection{Wave Energy Resource Estimates}

The Mapping and Assessment of the United States Ocean Wave Energy Resource ${ }^{14}$ report, created by the Electric Power Research Institute (EPRI), assesses ocean wave energy potential along the U.S. coasts. The report finds that the technically recoverable resource for electric generation from waves is about 1,170 TWh/year, which is almost one third of the 4,000 TWh of electricity used in the United States each year. Developing just a small fraction of the available wave energy resource could allow for millions of American homes to be powered with this clean, reliable form of energy. For context, about 85,000 homes can be powered by $1 \mathrm{TWh} /$ year.

The wave power density graphic shown below in Figure 3 illustrates the greater strength of this resource on the West Coast relative to the East Coast, with extremely high-power densities along many Alaskan islands in the Aleutian Chain and along southeast Alaska.

\footnotetext{
${ }^{14}$ Mapping and Assessment of the United States Ocean Wave Energy Resource, Electric Power Research Institute, December 2011.
} 


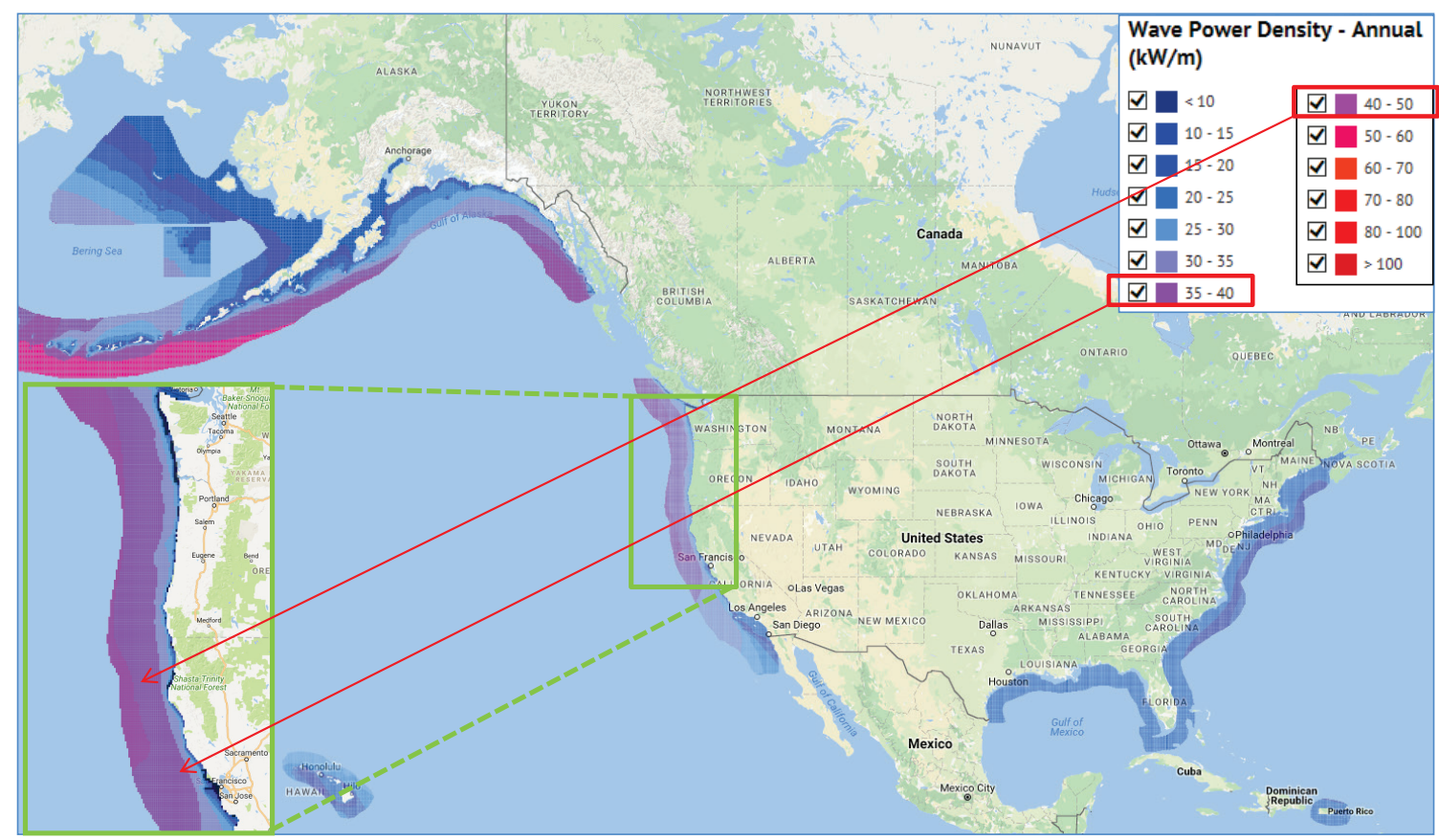

Figure 3. U.S. wave power density ${ }^{15}$

\subsubsection{Tidal Resource Estimates}

The Assessment of the Energy Production Potential from Tidal Streams in the United States ${ }^{16}$ report, created by the Georgia Tech Research Corporation, assesses the theoretically available energy in the nation's tidal streams. Based on DOE analysis of the data contained in the final report, the technical resource potential for tidal generation is estimated to be $250 \mathrm{TWh} /$ year. Alaska contains the largest number of locations with high kinetic power density, followed by Maine, Washington, Oregon, California, New Hampshire, Massachusetts, New York, New Jersey, North and South Carolina, Georgia, and Florida. The average tidal stream power density at a number of these locations exceeds 8,000 watts per square meter, which provides strong signals to tidal energy developers looking to test and deploy their devices.

\footnotetext{
${ }^{15}$ NREL MHK Atlas (beta release). Web source: maps.nrel.gov/mhk-atlas

${ }^{16}$ Assessment of the Energy Production Potential from Tidal Streams in the United States, Georgia Tech Research Corporation, DOE-funded report: DE-FG36-08GO18174, June 2011.
} 


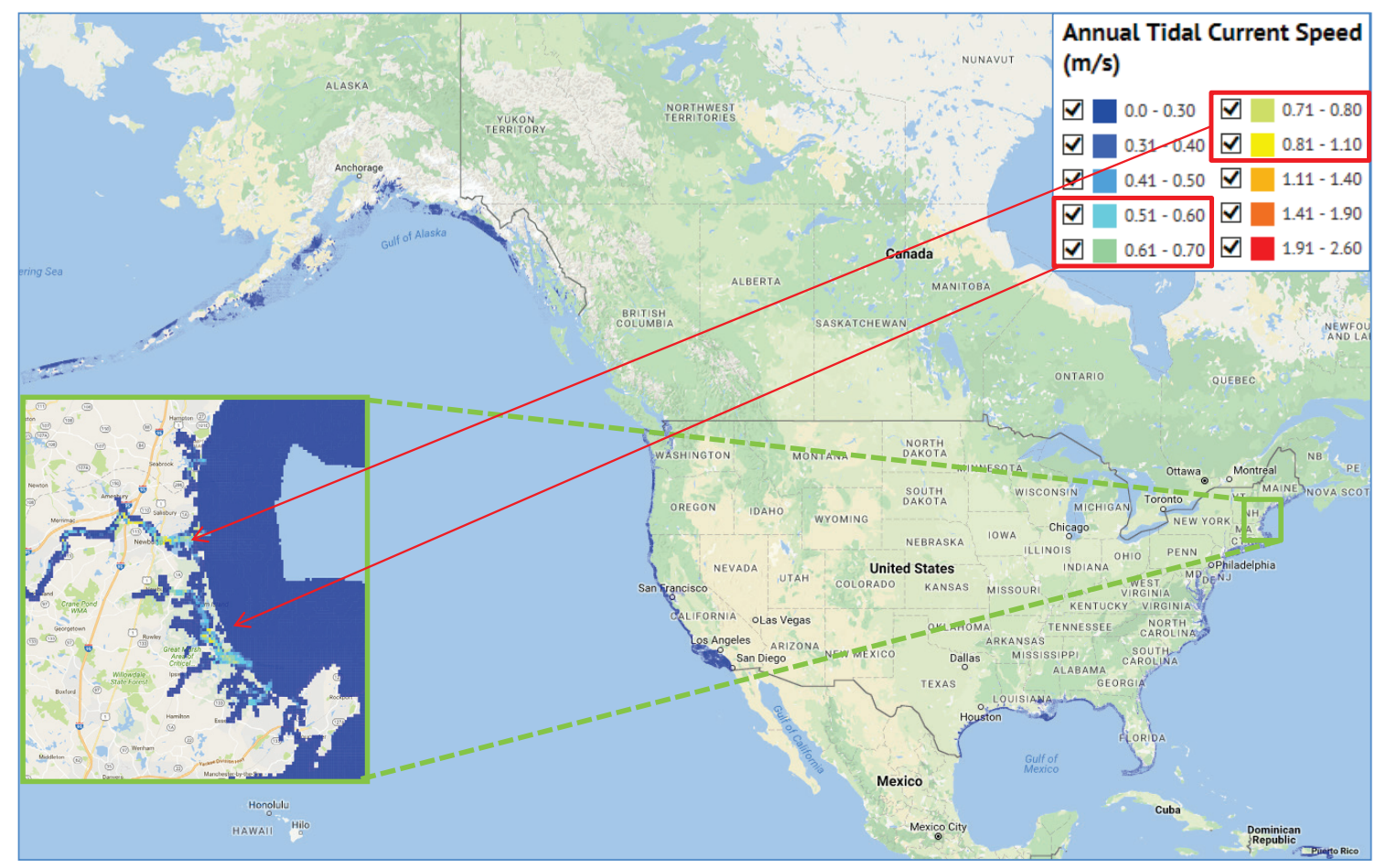

Figure 4. U.S. tidal current resource

\subsubsection{Ocean Current Resource Estimates}

A study, Assessment of Energy Production Potential from Ocean Currents along the United States Coastline,${ }^{17}$ conducted by the Georgia Tech Research Corporation, assesses the maximum theoretical power resource contained in the ocean currents. The technical resource potential for generation is estimated to range between 45 and $163 \mathrm{TWh} / \mathrm{yr}$. The potential power available for extraction in the Florida Current region of the Gulf Stream is about $5.1 \mathrm{GW}$ (corresponding to about $45 \mathrm{TWh} / \mathrm{yr}$ of generation). Considering a larger region of the Gulf Stream - within 200 miles of the U.S. coastline from Florida to North Carolina - the potential power available for extraction is about $18.6 \mathrm{GW}$ (or roughly $163 \mathrm{TWh} /$ year of energy). This ocean current resource can be seen graphically in Figure 5.

\footnotetext{
${ }^{17}$ Assessment of Energy Production Potential from Ocean Currents along the United States Coastline, Georgia Tech Research Corporation, DOE-funded report: DE-EE0002661, September 2013.
} 


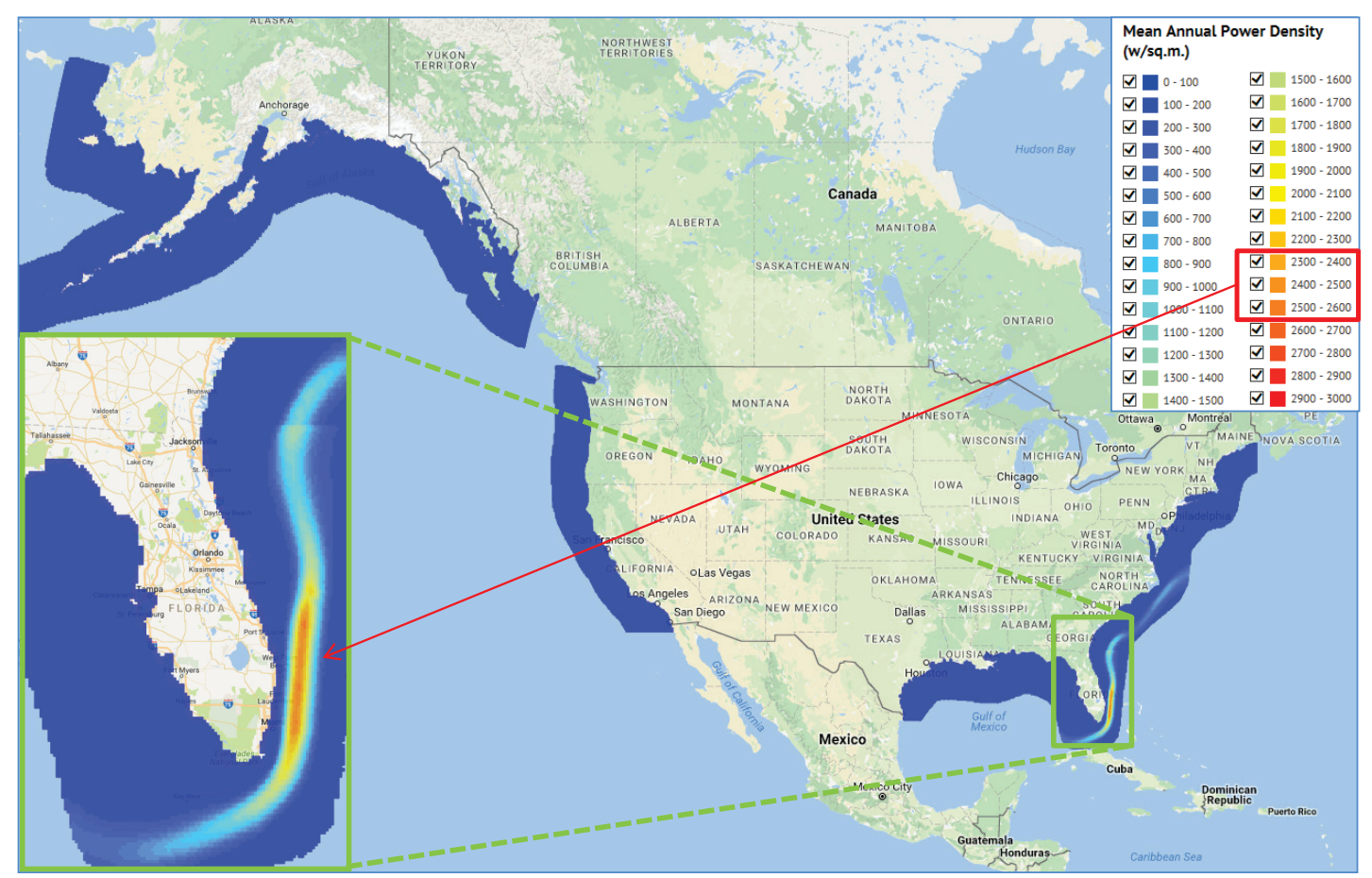

Figure 5. U.S. ocean current power density

The mean annual power density in the Florida Current within close proximity to the southeastern coast of Florida is in the 2,300-2,600 W/ $\mathrm{m}^{2}$ range. Continued development of more efficient and cost-effective ocean current energy harvesting devices will drive the eventual deployment of these devices in large arrays in this portion of the Gulf Stream that will deliver electricity to southern Florida. Development of these ocean current resources and delivering electricity on-shore will largely be done completely independent of military operations at coastal DOD facilities. Although there may be impacts to DOD operations in the ocean, it is expected that there will not be any significant impact of operations at DOD bases themselves, with an electricity transmission cable landing at an appropriate location on base being the largest potential impact.

Consequently, the ocean current resource and its potential to power coastal DOD bases in Florida was excluded from this study because little forward planning at the facility level is needed to accommodate or use this particular MHK technology when it becomes commercially viable as there would simply be a large electric cable brought to shore and tied to the substation on base 


\section{MHK Screening Assessment}

NREL identified DOD facilities for potential MHK development across the 50 states by using geographic information system (GIS) data, as well as key filtering and siting consideration assumptions described below. This study provides a coarse overview of domestic opportunities for MHK development on and near military or Department of Homeland Security (DHS) facilities. This report does not provide specific information required for siting MHK projects in specific locations, but it does offer perspectives on the magnitude and general location of promising areas. Estimates of potential MHK development are based on existing sources of wave and tidal resource data, bathymetric data, environmentally sensitive areas, and basic filtering criteria.

Through the process of screening and efforts to determine the tidal and wave resources for all of the coastal bases and facilities within DOD, a counterintuitive, but common, siting characteristic of these bases became more apparent. Using the U.S. Coast Guard as probably the most pronounced example, it is logical that their facilities would be on the coasts of the ocean, bays, and tributaries so that they can be in close proximity to provide the best service to their various constituents. And, the coastal areas of the ocean, bays, and tributaries would be in close proximity to the better wave and tidal resources.

Coast Guard personnel serve many functions, but critical to both their operation and the safety of the populations they serve is their ability to respond to environmental emergencies such as hurricanes, tidal waves, tornadoes, and extreme winter storms. If their bases were sited right on the coast at these locations, their boats, docks, and other equipment would probably be damaged or destroyed by the extreme weather event and they would be less likely to be able to provide the emergency services needed. It seems apparent that years ago, Coast Guard facility planners took those extreme weather events into account when siting bases so that their bases, boats, docks, and equipment would be outside the extreme impact zone - thus ensuring that they would be able to more effectively provide emergency services as needed for the impacted communities.

In regard to MHK resources, this prudent base-siting approach results in many of the Coast Guard facilities being well away from the best MHK resources because they are located in sheltered coves or inlets. Of course, as technology develops and the resultant LCOE comes down, simply extending the transmission distance from where the resources are best to the Coast Guard facilities may be an effective solution.

The Army and Air Force bases may have had different strategic priorities in base planning and siting, but the end result in terms of proximity to the better MHK resources are often similar.

The resource assessment for wave and tidal power examined the available resource at 1- and 5-mile radii from the base. The analysis for this initial screening focused on areas where the cost of deployment is expected to be low due to the level of resource and its proximity to the base. The mean 1-mile values were selected for wave and tidal resource to develop a more well-defined site comparison methodology. Other datasets for electrical transmission and more than 70 types of environmental and technical considerations were used to preliminarily rank sites by strongest resource and fewest technical and environmental issues. Sites were ranked by number of exclusions, strength of resource, proximity to the resource, size of the available resource, size of the facility electric load, and estimated cost of energy. Further detail regarding the screening process can be found in the Screening Criteria section of this report.

The preliminary results of the GIS screening, as seen in Table 7, Table 8, and Table 9 were then used by the DOD and NREL to down-select to two facilities to be visited by NREL and DOD for further 
investigation into the deployability potential of MHK devices at DOD bases. The Army, Coast Guard, and Air Force RE leads, with input from base personnel, provided site-specific informationsuch as cost of electricity, potential mission conflicts for MHK development, and ongoing renewable energy projects for each of the screened sites - that was used to identify the DOD installations to be visited.

The following sites were selected for site visits that were completed in Q2 and Q3 of FY17:

- U.S. Coast Guard Training Center Cape May (TRACENCM), Cape May, New Jersey

- U.S. Army National Guard Camp Edwards in Barnstable County, Massachusetts. Camp Edwards is the largest of five co-located bases at Joint Base Cape Cod.

\subsection{Data Sources}

The Department of Homeland Security maintains a database of the location and extent of nearly all DOD-owned facilities. This includes sites used by Army, Navy, Coast Guard, Marines, Air Force, and National Guard. The resulting database of nearly 6,200 DOD-owned sites was screened against wave, tidal, and ocean current resource data, as well as more than 70 state and national environmental and bathymetric datasets to determine which sites had the highest potential for the deployment of MHK technologies. For this report, the Navy and Marine bases were excluded because they had been specifically screened in the previous MHK study.

\subsubsection{Wave Resource Data}

Wave resource data ${ }^{18}$ created by Virginia Tech, EPRI, and NREL were used in the screening process. The study used a 51-month Wavewatch III hindcast dataset that was developed specifically for the study by the National Oceanographic and Atmospheric Administration's (NOAA's) National Centers for Environmental Prediction. Wave power density, in terms of kilowatts per meter, is aggregated across a unit-diameter circle when estimating total resource. This approach is consistent with accepted practice, which includes the resource from the lateral transfer of wave energy along crests.

The total available energy resource along the U.S. continental shelf edge, based on accumulating unit-circle wave power densities, is estimated to be $2,640 \mathrm{TWh} / \mathrm{yr}$, broken down in Table 1 . This estimate will most likely change as both measurement and energy-converting devices evolve and technical constraints such as mooring depth and site suitability are considered.

Table 1 shows a total recoverable resource along the coasts, considering the total renewable wave energy resource, as constrained by an array capacity packing density of 15 megawatts per kilometer of coastline, with a 100-fold operating range between thresholds and maximum operating conditions in terms of input wave power density available to such arrays.

\footnotetext{
${ }^{18}$ http://maps.nrel.gov/mhk atlas
} 
Table 1. Total Available Wave Energy Resource

\begin{tabular}{lcc}
\hline Region / Location & $\begin{array}{c}\text { Total Available } \\
\text { Wave Energy } \\
\text { Resource }\end{array}$ & $\begin{array}{c}\text { Total Recoverable } \\
\text { Wave Energy } \\
\text { Resource }\end{array}$ \\
\hline (TWh/yr) & (TWh/yr) \\
\hline West Coast & 590 & 250 \\
East Coast & 240 & 160 \\
Gulf of Mexico & 80 & 60 \\
Alaska & 1570 & 620 \\
Hawaii & 130 & 80 \\
Puerto Rico & 30 & 20 \\
\hline \hline Total U.S. Available Energy & & \\
Resource (2014 estimate) & $\mathbf{2 , 6 4 0}$ & $\mathbf{1 , 1 9 0}$ \\
\hline
\end{tabular}

\subsubsection{Tidal Resource Data}

Tidal resource data ${ }^{19}$ from a U.S. DOE-funded regional assessment effort ${ }^{20}$ by GA Tech and ORNL was used by NREL for screening sites with tidal current potential. The regional assessment highlighted areas with $500 \mathrm{~W} / \mathrm{m}^{2}$ average kinetic power density and higher, surface area larger than $0.5 \mathrm{~km}^{2}$, and depth greater than $5 \mathrm{~m}$. The locations that meet or exceed these criteria are in Alaska (AK), Maine (ME), Washington (WA), Oregon (OR), California (CA), New Hampshire (NH), Massachusetts (MA), New York (NY), New Jersey (NJ), North and South Carolina (NC, SC), Georgia (GA), and Florida (FL). Some locations were found to have surface areas of hundreds of square kilometers. See Appendix B for a more detailed description of tidal modeling methods.

\subsubsection{Bathymetric Data}

Bathymetric data were taken from the publicly available NOAA Geophysical Data Center, ${ }^{21}$ which is a compilation of the U.S. National Ocean Service Hydrographic Database, ${ }^{22}$ U.S. Geological Survey (USGS), Monterey Bay Aquarium Research Institute, U.S. Army Corps of Engineers, and various other academic institutions. Topographic data are from the USGS and the Shuttle Radar Topography Mission (SRTM).

\subsubsection{Environmentally Sensitive Areas}

NREL contracted with Black and Veatch in 2009-2010 to identify marine areas of the 50 U.S. states that could potentially be excluded from energy development. This study compiled state and federal databases including exclusion areas such as undersea pipelines and platforms, as well as environmentally sensitive areas such as Marine Protected Areas. Roughly 150 different types of Federal exclusions or environmentally sensitive areas were identified, along with more than 400 different state criteria. This dataset is extremely complex and represents overlapping constraints and regulatory jurisdictions. For this reason, site-specific analyses beyond dataset compilation are necessary to fully characterize the suitability of a particular site for MHK energy development.

\footnotetext{
19 http://www.tidalstreampower.gatech.edu/

20 http://www.tidalstreampower.gatech.edu/Final_Report tidal_v2.pdf

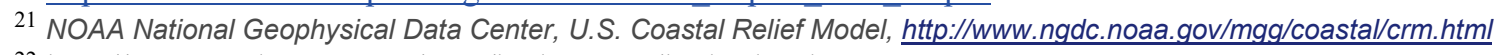

${ }^{22}$ http://www.ngdc.noaa.gov/mgg/bathymetry/hydro.html
} 
Technical exclusions based on resource, supporting technologies such as undersea cable limitations, depth constraints for navigable waterways, and other exclusions can be found in Table 2 . These exclusions limit the areas that can be developed and represent a higher possibility of long-term deployability for any given site. Further refinement of this effort should include additional technical exclusions such as sea bottom type, seismic risk, and other criteria that affect the deployability of any technology.

\subsubsection{Other Environmental Data}

Understanding the environmental impacts of deploying MHK technologies at scale is a vast area of research and knowledge that continues to grow and evolve with the technologies themselves. The DOE has partnered with and supported the Pacific Northwest National Laboratory (PNNL) to develop the Tethys database resource that is intended to:

- Facilitate the exchange of information and data on the environmental effects of marine renewable (and wind) energy technologies; and

- Serve as a commons for marine renewable (and wind) energy practitioners and therefore enhance the connectedness of the renewable energy community as a whole.

This collaborative resource is a "smart" database integrating the Knowledge Encapsulation Framework (KEF) software developed at PNNL that enhances data organization and search functions. Tethys is intended to foster communication and increased understanding between MHK stakeholders such as project developers; regulatory agency staff; industry, environmental and local stakeholders; and researchers. More detailed information can be found at https://tethys.pnnl.gov/map-viewer-marine-energy.

Although the Tethys database was not used in the base screening in this report, it is an important environmental information source whose educational resources and relevance are continually increasing and should be used by DOD in any future MHK investigations.

Additionally, the DOE has joined with the International Energy Administration (IEA) Ocean Energy Systems (OES) collaborative international group, Annex IV, which was formed in 2010 to share knowledge and expertise on the environmental effects of marine renewable energy (MRE) development. The DOE has partnered with the U.S. Bureau of Ocean Energy Management (BOEM) and NOAA to contribute to this expanding body of knowledge as the industry grows and gains experience. PNNL manages this internationally oriented platform within the Tethys database website. (For more information, see https://tethys.pnnl.gov/about-annex-iv). Again, this is included for its educational value for any future MHK projects at DOD facilities.

\subsubsection{Electrical Infrastructure Data}

For initial DOD facility screening, the transmission line locations and voltages, along with substation locations and voltages, were taken from Ventyx Energy Velocity Suite (C2013, which is a purchased dataset produced by a private entity.

For more detailed screening among bases with identifiable wave and tidal resources, the DOD RE leads and base energy managers provided more accurate information regarding individual facility loads and electrical infrastructure.

\subsubsection{DOD Facility Location Data}

DOD facility locations were compiled through the Homeland Infrastructure Foundation-Level Data Working group, which includes more than 5,000 participating partners with the four leading agencies 
being the DHS, DOD, National Geospatial-Intelligence Agency, and USGS. Specifically, the Homeland Security Infrastructure Program (HSIP) Gold dataset ${ }^{23,24}$ was used to locate all DODowned facilities used in the initial screening.

The initial screening was greatly enhanced by direct conversations with the RE leads within the Army, Coast Guard, and Air Force, where high-ranking sites were discussed for MHK potential with more qualified perspectives on potential "developability" at various DOD facilities based on personal knowledge of the site itself, type and extent of operations, size of load, future base expansion or contractions plans or potential, and insight into potential conflicts with operations that are not contained in any publicly available database.

\subsection{Screening Criteria}

Because MHK technologies are currently not commercial, this study highlights DOD facilities that have the highest potential for future MHK deployments. Thus, bases with strong wave or tidal resources or with large areas suitable for MHK technology deployment are reported here. Table 2 shows the criteria used to help identify and screen the sites with the highest potential for deployment. Additionally, high cost of electricity (COE) is an important consideration in screening for long-term potential, although $\mathrm{COE}$ figures were not always available for every base. In these instances, statewide average price for industrial electricity were used as an estimate for the base.

It should be noted that with any new energy technology, the sites with the highest resource and/or highest market cost of electricity will likely be among the first developed. Using wind energy in the United States as an example, ${ }^{25}$ as the industry has matured over the past two decades, the level of wind resource required to be cost competitive with other forms of electrical generation has fallen. Based on this experience, we can reasonably expect the commercially viable threshold of the wave or tidal resource to fall over time as MHK technologies become more widely deployed and lessons are learned from mechanical efficiency, manufacturing cost reductions, deployment economies of scale, and more from these deployments. Thus, the resource thresholds in Table 2 are very low when compared to the sites in which MHK device manufacturers are currently deploying devices. The goal in using very low resource thresholds is to prevent excluding DOD sites that may have other advantages for the future deployment of MHK devices as economic and efficiency factors improve. This study's outlook is 5-20 years in the future, by which time deployment of MHK devices may be cost effective even at these lower threshold values. Other criteria, such as technical limitations for maximum undersea cable depth, minimum depths for tidal turbines, and maximum mooring depth for wave devices were used to further screen sites for technical feasibility.

NREL performed GIS proximity screenings by applying the screening criteria shown in Table 2 . The resulting information includes: proximity to transmission including distance to substations and interconnection voltage; number of environmental layers or constraints present; proximity to the DoD facility; resource magnitude; and depth limitations due to the type of MHK resource.

\footnotetext{
${ }^{23}$ http://www.dhs.gov/infrastructure-information-partnerships\#2

${ }^{24}$ HSIP Gold, C2012; For Official Use Only

${ }^{25}$ P.46 Wiser, R.; Bollinger, M. 2012 Wind Technologies Market Report. Washington, DC: Department of Energy,

2012. Accessed 2014: https://www1.eere.energy.gov/wind/pdfs/2012_wind technologies_market report.pdf
} 
Table 2. General Screening Criteria

Criterion Wave Tidal

\begin{tabular}{|c|c|c|}
\hline \multicolumn{3}{|c|}{ Physical/Environmental Characteristics } \\
\hline Electrical Infrastructure & \multicolumn{2}{|c|}{ Proximity to a Substation for Voltage Step-down } \\
\hline Environmental Layers Present & \multicolumn{2}{|c|}{ Minimize Relative to Other Sites per Same Technology } \\
\hline \multicolumn{3}{|l|}{ Resource Characteristics } \\
\hline Proximity to DOD Facility & $<1$ or $<5$ miles & $<1$ or $<5$ miles \\
\hline Magnitude of Mean Resource & $>4 \mathrm{~kW} / \mathrm{m}$ & $>0.6 \mathrm{~m} / \mathrm{s}$ \\
\hline Depth of Resource Limitation & $<150 \mathrm{~m}$ & $<150 \mathrm{~m}$ \\
\hline
\end{tabular}

Within the general categories displayed in Table 2, more detailed screening factors were applied. An example of the specific screens applied to the wave resource data can be seen in Table 3 below. As shown, multiple criteria are overlain so that the resultant resource figure represents an area that meets multiple criteria (i.e., depth, minimum resource, etc.) simultaneously. These screens were limited to $150 \mathrm{~m}$, although there is no established standard for what depth limits should be or may resolve to be with continued technology development. The screen was also applied for a 5-mile radius from base or facility.

Table 3. Applied Screening Criteria for Wave Energy Resource

\section{Criteria Name}

Mean01_150
Max01_150
Area01_150

Distance01_150

\section{Criteria Definition}

Area-weighted annual average wave power density, 1 mile, minimum $4 \mathrm{~kW} / \mathrm{m}^{2}$, maximum depth $150 \mathrm{~m}$

maximum annual average wave resource $\left(\mathrm{kw} / \mathrm{m}^{2}\right), 1$ mile, maximum depth $150 \mathrm{~m}$

Area (square meters) of area-weighted annual average, 1 mile, minimum $4 \mathrm{~kW} / \mathrm{m}^{2}$, maximum depth $150 \mathrm{~m}$

Distance from edge of base/station to usable resource of area, within 1 mile, minimum $4 \mathrm{~kW} / \mathrm{m}^{2}$, maximum depth 150 meters

A comparable multi-criteria screen was applied to tidal current and the articulated definition can be seen in Table 4.

Table 4. Applied Screening Criteria for Tidal Current Resource

Criteria Name Criteria Definition

Mean01_150 Area-weighted annual average, 1 mile, minimum $0.6 \mathrm{~m} / \mathrm{s}$, maximum depth 150 meters

Max01_150 Maximum annual average, 1 mile, minimum $0.6 \mathrm{~m} / \mathrm{s}$, maximum depth 150 meters

Area01_150

Area (square meters) of area-weighted annual average, 1 mile, minimum $0.6 \mathrm{~m} / \mathrm{s}$, maximum depth 150 meters

Distance01_150

Distance from edge of base/station to usable resource of area, within 1 mile, minimum $0.6 \mathrm{~m} / \mathrm{s}$, maximum depth 150 meters

To help identify and establish potential project development barriers before extensive resource analyses were undertaken, a series of environmental and marine infrastructure constraints were applied at 1- and 5-mile radii. The environmental constraints applied are listed in Table 5. 
Table 5. 1- and 5-mile Environmental Constraints Applied in Initial Screening

\begin{tabular}{|l|l|}
\hline Coastal migratory pelagics & Estuaries \\
\hline Coral, coral reef, live or hard bottom & Rocky reef \\
\hline Proposed deepwater lophelia coral & Seagrass \\
\hline Dolphin and wahoo & Crab spawning sanctuaries \\
\hline Shrimp & Sea turtle sanctuary \\
\hline Snapper grouper & Significant natural heritage areas \\
\hline Spiny lobster & Conservation focus areas \\
\hline Oculina & Habitat restoration sites \\
\hline Official sanctuary protection areas & Refuges \\
\hline Cordell Banks closed areas & Audobon sanctuaries \\
\hline Oregon marine managed areas & National marine sanctuary \\
\hline Oregon Island National Wildlife Refuge & State coastal preserves \\
\hline Marine protected areas & National wildlife refuges \\
\hline National marine sanctuaries & Crab sanctuary \\
\hline Coastal national wildlife refuges & Nearshore coastal parks or national preserves \\
\hline Aquatic preserve boundaries & Striped bass sanctuary \\
\hline Canopy kelp & Threatened/endangered species waters \\
\hline
\end{tabular}

State parks and natural preserve boundaries

The same approach was taken with various infrastructure factors. The infrastructure constraints applied in the screening are listed in Table 6 below.

Table 6. 1- and 5-mile Infrastructure Constraints Applied in Initial Screening

\begin{tabular}{|l|}
\hline Shipping routes \\
\hline Ferry routes \\
\hline Navy and Marine infrastructure - shipping lanes \\
\hline Grid of wind siting map -exclusions and avoids \\
\hline Ocean dredged material disposal sites \\
\hline Dredged material disposal and placement sites \\
\hline Navy and Marine infrastructure - fairways \\
\hline Navy and Marine infrastructure - pipelines \\
\hline Navy and Marine infrastructure - drilling platforms \\
\hline Underwater cables \\
\hline Offshore oil and gas pipelines \\
\hline Offshore oil and gas drilling platforms \\
\hline NWIOOS - ship tow lanes \\
\hline Hazardous material sites \\
\hline Excluded water use types \\
\hline Pipelines and miscellaneous easements \\
\hline Gulf intracoastal waterway/ship channels \\
\hline Shipping safety fairways \\
\hline Security areas
\end{tabular}




\subsubsection{Screening Criteria Limitations and Discussion}

Some of these criteria are slightly more qualitative than others. The initial screening net was probably cast too wide and included several smaller military installations that do not qualify as bases and whose small loads may not be suitable to early MHK market entry; however, they may have potential as pilot project test facilities if a number of other project factors were strong. The need to filter out the smaller bases became more apparent through discussion with the RE leads for each branch.

In general, environmental siting considerations vary widely in their potential impact on a possible MHK project. For example, a marine-protected sanctuary may pose a larger hurdle than a known bed of seagrass to a potential MHK project, although both were weighted equally in this analysis. And both might show up in a 1-mile radius screen and be weighted equally, although one may be in the middle of a potential deployment site whereas another is 0.8 of a mile away and of little environmental impact. Another complicating factor is that many of the different environmental data layers come from both national- and state-level jurisdictions that vary widely in their intent, how the species-protection guidelines are articulated, and the potential added cost to MHK project development. However, generally speaking, a site with fewer environmental siting considerations may have a lower probability of having one of the siting considerations considerably increase the cost and time of development and deployment. Other variables - such as type of MHK technology, water depth, and proximity to known sensitive marine habitat - may also impact the feasibility of a MHK project.

Other criteria, such as distance to a substation, assumed that the power from an MHK project would be brought to shore for distribution to the base, rather than for injection onto the utility grid.

Currently, sites may only be interested in test devices or very small-scale deployments of MHK devices that would not require a high-voltage interconnection. In the future, much larger deployments of MHK devices may be advantageous due to the economies of scale of larger systems, at which point relatively high voltage and closer interconnection proximity may enhance project viability. Again, even when considering very large potential project sizes of $100 \mathrm{MW}$ or more, the required interconnection voltage may vary wildly depending on factors such as specific line capacity, location of interconnection, and seasonal and diurnal resource or load variations. Another possibility would be a site that intends to offset its own electrical demand, which may require minimal transmission availability if the base's interconnection has sufficient capacity. Thus, these qualitative criteria require site-specific consideration depending on project size, specific MHK technology, and more. The expectation is that as MHK technology continues to evolve, project suitability for offsetting on-base DOD loads vs. supplying power to the utility grid will be better understood, and interconnection issues will have greater commonality of successful approaches.

\subsection{Scoring Methodology}

For pre-commercial technologies such as MHK, it is challenging to attempt to forecast the critical project development factors 5-20 years into the future. Obviously, the level of MHK resource will be important. Because commercial MHK farms have not been deployed in the United States, it is largely speculation as to what non-resource project factors will ultimately carry the most weight—whether positively or negatively - in impacting which projects get built. What may appear to be a barrier today may be readily resolved in 10 years. Energy conversion efficiencies may evolve such that there will be an optimized tidal current speed range or a maximum wave power density to avoid because it shortens the effective life of the WECs. 
Despite the uncertainty, efforts were made to establish a scoring methodology based on practical consideration of known project factors today with a simplified weighting mechanism integrated into the scoring. As technology develops and real projects are built, actual project data will be collected that will determine what project factors should be scored in deciding whether or not to move forward with a potential MHK project; the relative importance or weighting of those factors will also be more readily understood.

The following series of scoring equations are meant to make transparent the methodology employed in this analysis. The intent is improvements being made to these equations, eliminating some while adding others, to more accurately reflect and weight relevant MHK project factors. Several tidal current equations and their rationale will be presented as examples, followed by several wave equations. The scoring is also visually weighted - that is, darker green is associated with a better score and lighter green or white is a less beneficial score.

\subsubsection{Tidal Energy Scoring Equations}

The following series of equations were used to differentiate the potential for tidal energy development at DOD bases and Coast Guard stations. In all cases, a higher score is better. 


\subsubsection{Mean Tidal Current Speed}

Scoring logic applied:

Area-weighted mean tidal current speed (TCS) $<0.6 \mathrm{~m} / \mathrm{s}$ is not suitable for current devices. Above $2.0 \mathrm{~m} / \mathrm{s}$ would enable multiple devices to reap effective tidal energy. In between, the approximate line reflects the increasing value of higher mean tidal current speeds.

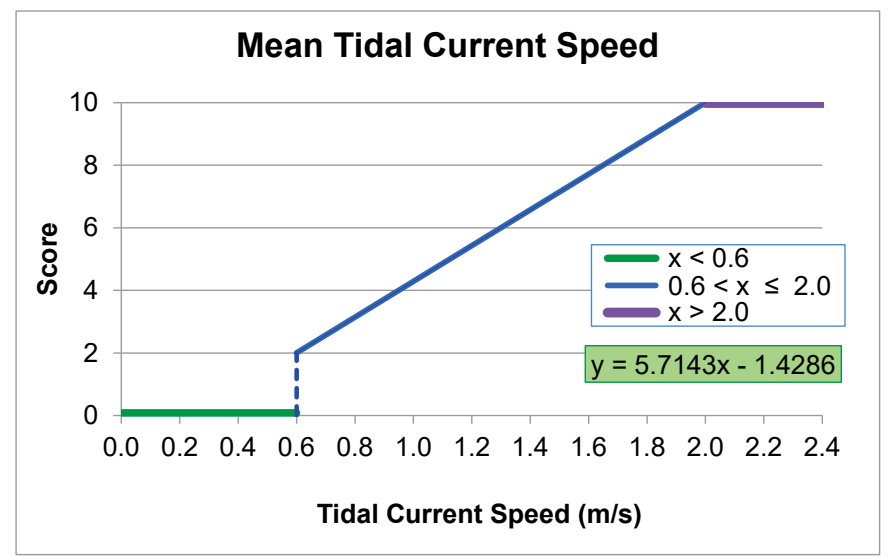

\begin{tabular}{|l|c|}
\hline $\operatorname{TCS}(\mathrm{m} / \mathbf{s})$ & Score \\
\hline $0-0.6$ & 0 \\
\hline $0.6-2.0$ & $5.7143 x-1.4286$ \\
\hline $2.0+$ & 10 \\
\hline
\end{tabular}

Figure 6. Mean tidal current speed scoring equation and table

\subsubsection{Maximum Tidal Current Speed}

Scoring logic applied:

Periodic intervals with the available maximum TCS (MaxTCS) being above the mean TCS (MeTCS) provide opportunities for increased annual energy production, sometimes significantly, at a site. The actual benefit will be location-specific, and the advantage may oscillate diurnally, seasonally, with spring tides, or more randomly. With more detailed information regarding the MaxTCS characteristics, the added annual energy production benefit may influence the selection of one site over another. This tidal-speed characteristic was scored as a ratio of maximum to mean (shown in the table below) on a five-point, rather than ten-point, basis to minimize the double-counting effect associated with a location that has a good tidal resource while providing differentiation associated with increasing annual energy production.

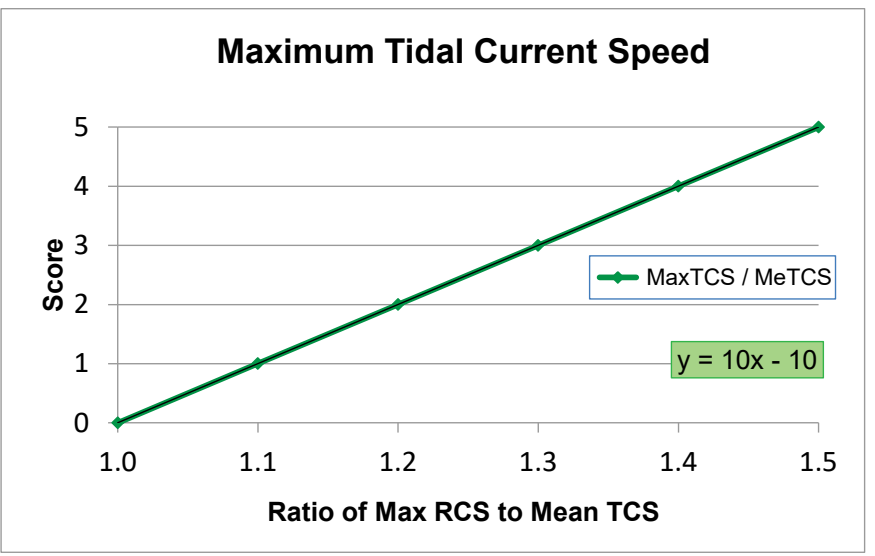

\begin{tabular}{|c|c|}
\hline Max TCS / Mean TCS & Score \\
\hline MxTCS $^{*}=$ MeTCS $^{* *}$ & 0 \\
\hline $1<$ MxTCS/MeTCS $<1.1$ & 1 \\
\hline $1.1<$ MxTCS/MeTCS $<1.2$ & 2 \\
\hline $1.2<$ MxTCS/MeTCS $<1.3$ & 3 \\
\hline $1.3<$ MxTCS/TCS $<1.4$ & 4 \\
\hline $\begin{array}{c}1.4<\text { MxTCS/MeTCS } \\
{ }^{*} \text { MxTCS }=\text { Max TCS; } \\
{ }^{* *} \text { MeTCS }=\text { Mean TCS }\end{array}$ & 5 \\
\hline
\end{tabular}

Figure 7. Ratio of maximum to mean tidal current speed scoring and table 


\subsubsection{Tidal Area with TCS $>0.6 \mathrm{~m} / \mathrm{s}$}

Scoring logic applied:

Available area with a base amount of tidal resource is an important factor. The discrete function is an "estimate" made more easily useable with a "curve fit" equation. The difference in scoring points between the discrete, piecewise equation and the logarithmic function is minimal.

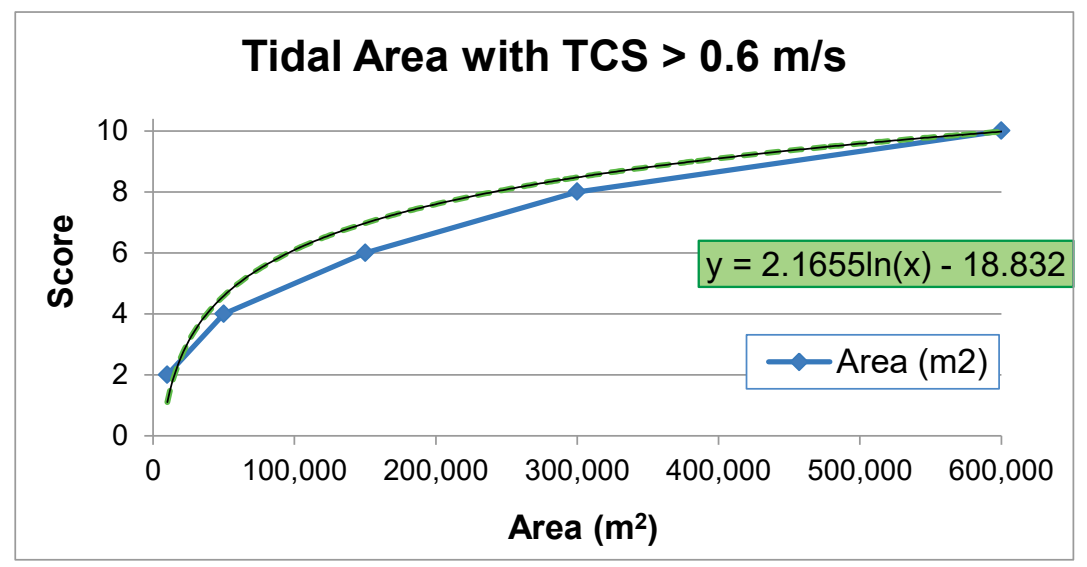

\begin{tabular}{|l|c|}
\hline \multicolumn{1}{|c|}{ Area $\left(\mathbf{m}^{2}\right)$} & Score \\
\hline $0-10,000$ & 0 \\
\hline $10,000-50,000$ & 2 \\
\hline $50,000-150,000$ & 4 \\
\hline $150,000-300,000$ & 6 \\
\hline $300,000-600,000$ & 8 \\
\hline$>600,000$ & 10 \\
\hline
\end{tabular}

Figure 8. Tidal area with mean tidal current speed $>0.6 \mathrm{~m} / \mathrm{s}$ and depth to $150 \mathrm{~m}$

\subsubsection{Distance to Tidal Resource}

Scoring logic applied:

The closer the base/station is to the tidal resource, the better. A maximum distance is not known, but this screen has a maximum radius of 1 mile $(\sim 1,600 \mathrm{~m})$, so the closer the base is to the resource, the better the score.

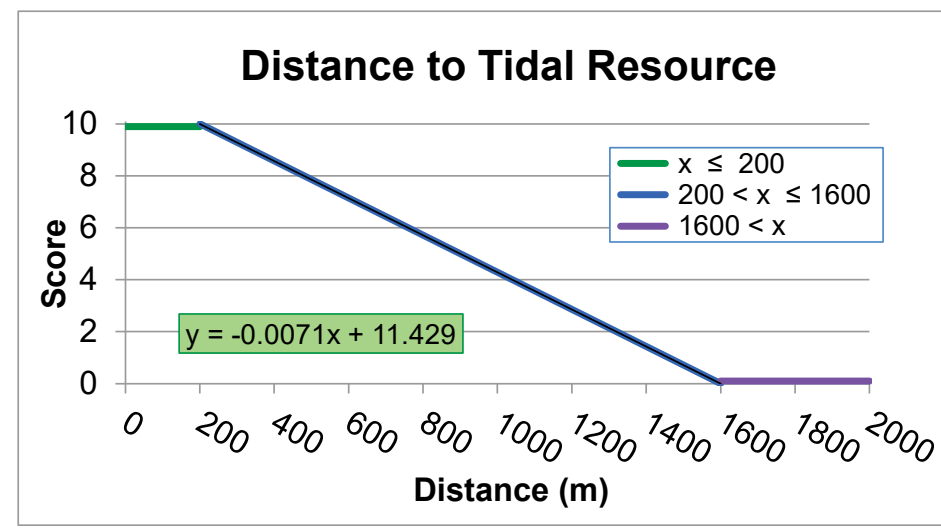

\begin{tabular}{|l|c|}
\hline Distance $(\mathbf{m})$ & Score \\
\hline $0-200$ & 10 \\
\hline $200-1600$ & $-0.0071 x+11.429$ \\
\hline
\end{tabular}

Figure 9. Distance to tidal resource scoring equation and table 


\subsubsection{Environmental and Other Exclusions}

Scoring logic applied:

Exclusions are not fully accounted for within the resource data. So, they are specifically counted here with the logic that each exclusion restricts the available area for MHK device deployment and adds more cost to the general environmental permit or to the operational costs mitigating the environmental issue.

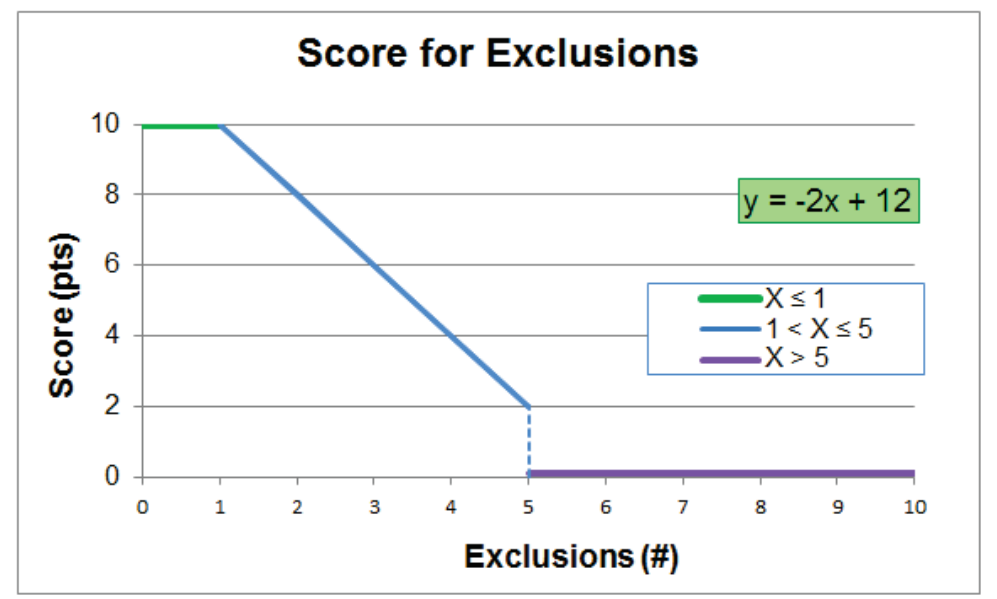

\begin{tabular}{|c|c|}
\hline Exclusions (\#) & Score \\
\hline$\geq 6$ & 0 \\
\hline 5 & 2 \\
\hline 4 & 4 \\
\hline 3 & 6 \\
\hline 2 & 8 \\
\hline $0-1$ & 10 \\
\hline
\end{tabular}

Figure 10. Environmental and other exclusions scoring equation and table

\subsubsection{Distance to Substation}

Scoring logic applied:

Once the power is brought to shore, then the closer the substation is-whether on or off base - the lower the cost of getting the power to the substation. A maximum distance is not known, but $\sim 1$ mile $(1,600 \mathrm{~m})$ was used as the maximum distance for this analysis.

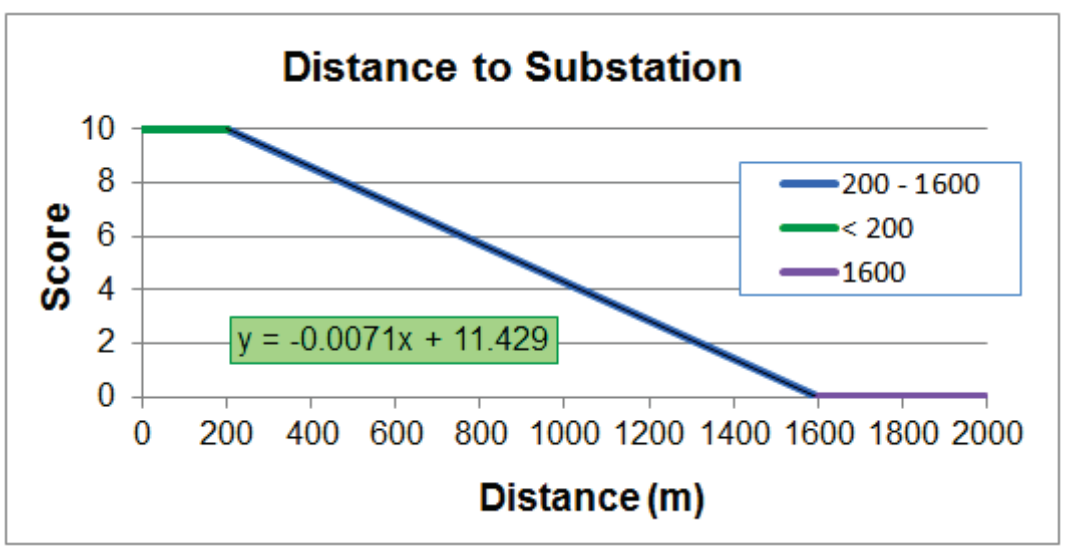

\begin{tabular}{|l|c|}
\hline Distance (m) & Score \\
\hline$<200$ & 10 \\
\hline $200-1600$ & $-0.0071 x+11.429$ \\
\hline$>160$ & 0 \\
\hline
\end{tabular}

Figure 11. Distance to the substation scoring equation and table 


\subsubsection{Base Demand}

Scoring logic applied:

In early stages of market development, MHK costs are expected to be high. It was assumed that after moving out of the prototype phase, large-scale deployments of MHK technology would offer a better chance at cost-effective deployments than what would be possible with small projects at small bases. So, a scoring premium was placed on base demand loads above $3,000 \mathrm{~kW}$ ( $3 \mathrm{MW}$ ), seen as being large enough to facilitate economies of scale in deployment.

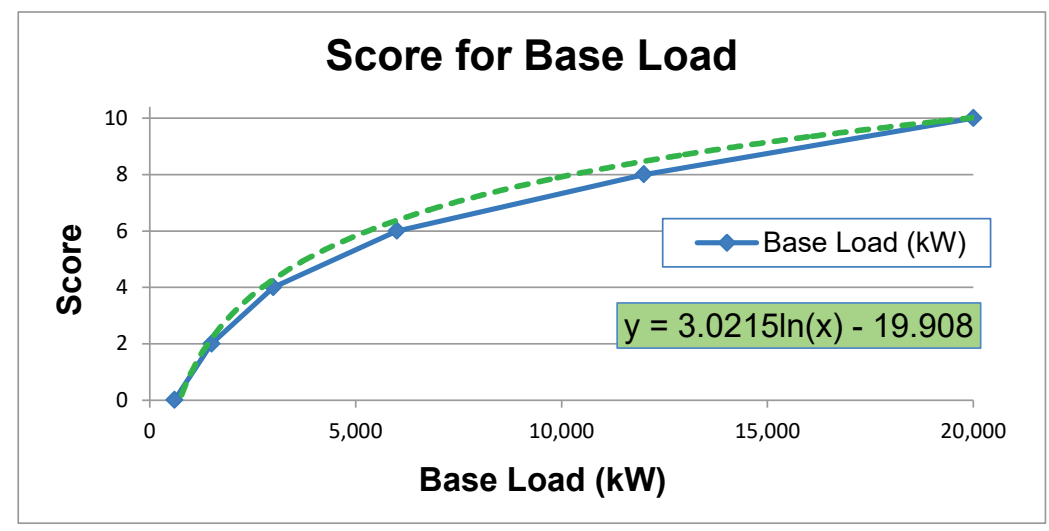

\begin{tabular}{|l|c|}
\hline Base Load (kW) & Score \\
\hline $0-100$ & 0 \\
\hline $100-500$ & 2 \\
\hline $500-1,000$ & 4 \\
\hline $1,000-3,000$ & 6 \\
\hline $3,000-8,000$ & 8 \\
\hline$>8,000$ & 10 \\
\hline
\end{tabular}

Figure 12. Base load scoring equation and table

\subsubsection{Cost of Electricity}

Scoring logic applied:

In early stages of market development, MHK costs are expected to be high. It was assumed that the better places would be at locations that already have a very high cost of electricity. DOD bases and Coast Guard stations on islands and remote places in Alaska are high-cost electricity markets that may develop into early adopters.

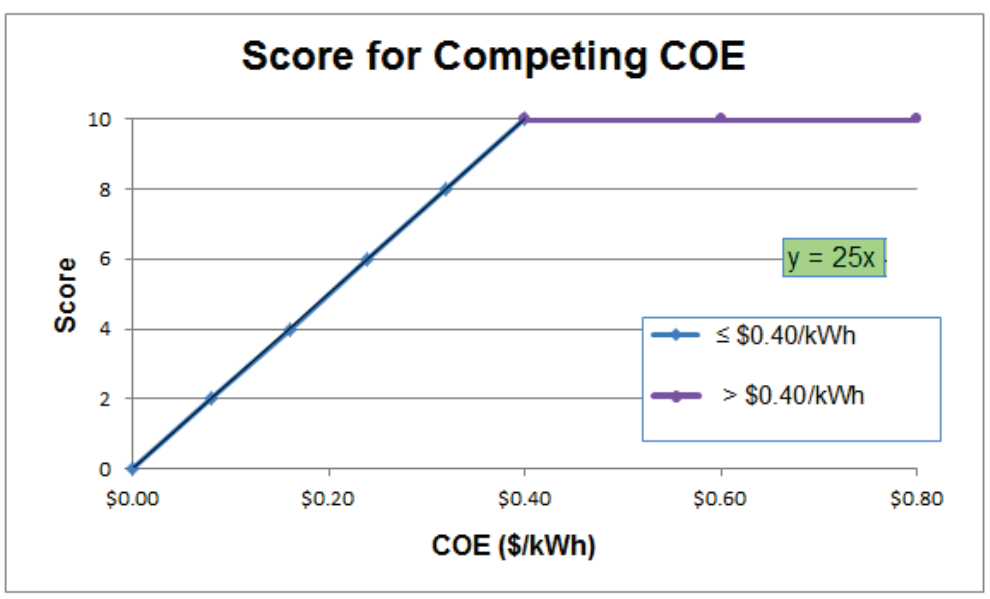

\begin{tabular}{|c|c|}
\hline COE (\$/kWh) & Score \\
\hline$\$ 0.00$ & 0 \\
\hline$\$ 0.08$ & 2 \\
\hline$\$ 0.16$ & 4 \\
\hline$\$ 0.24$ & 6 \\
\hline$\$ 0.32$ & 8 \\
\hline$\$ 0.40$ & 10 \\
\hline
\end{tabular}

Figure 13. Cost of electricity scoring equation and table 


\subsubsection{Wave Energy Scoring Equations}

The following series of equations were used to differentiate the potential for wave energy development at DOD bases.

\subsubsection{Mean Wave Power Density}

Scoring logic applied:

Area-weighted mean wave power density (WPD) is the driving force, although ideal power density depends on conversion device. A resource level below $4 \mathrm{~kW} / \mathrm{m}$ may not be enough power for viable extraction. A linear relationship is assumed. Overall, this may be a low threshold, but DOD sites are "where they are." During the past 10 years, the wind industry has ably demonstrated how early technological thresholds can be overcome with the introduction and development of low-windspeed turbines. Locations that were uneconomic for wind 20-30 years ago are now cost competitive with many other sources of electricity. It is too early in the technological development process for WECs to rule out what today may appear to be a low-resource location.

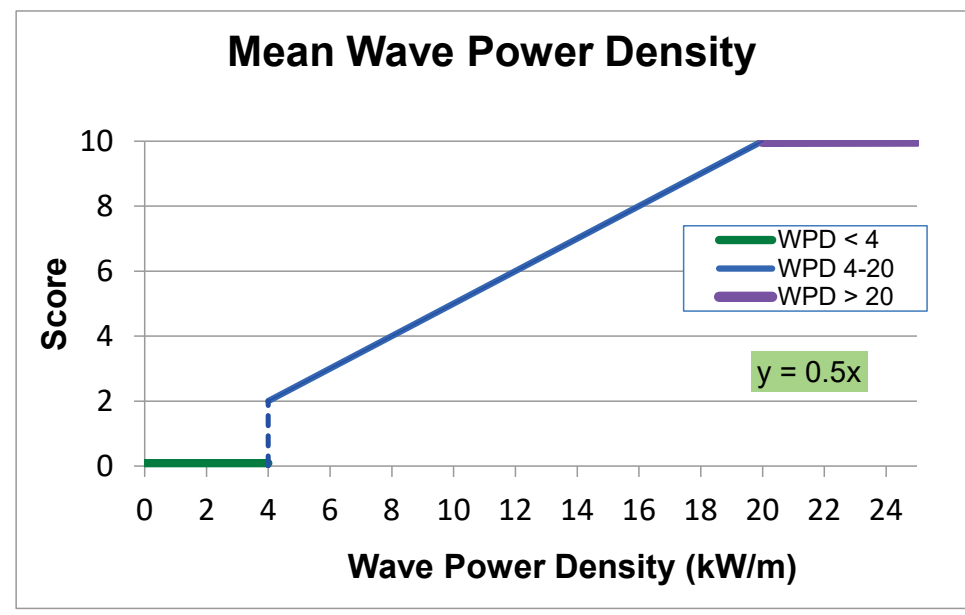

\begin{tabular}{|c|c|}
\hline TCS $(\mathbf{m} / \mathbf{s})$ & Score \\
\hline WPD $<4$ & 0 \\
\hline WPD 4-20 & $0.5 x$ \\
\hline$W P D>20$ & 10 \\
\hline
\end{tabular}

Figure 14. Mean wave power density scoring and table

\subsubsection{Maximum Wave Power Density}

Scoring logic applied:

Periodic intervals with the available maximum WPD (MaxWPD) being above the mean WPD (MeWPD) provide opportunities for increased annual energy production, sometimes significantly, at a site. The actual benefit will be location-specific, and the advantage may oscillate diurnally, seasonally or more randomly. With more detailed information regarding the MaxWPD characteristics, the added annual energy production benefit may influence the selection of one site over another. This wave characteristic was scored as a ratio of maximum to mean (shown in the table below) on a five-point, rather than ten-point, basis to minimize the double-counting effect associated with a location that has a good wave resource, while providing differentiation associated with increasing annual energy production. 


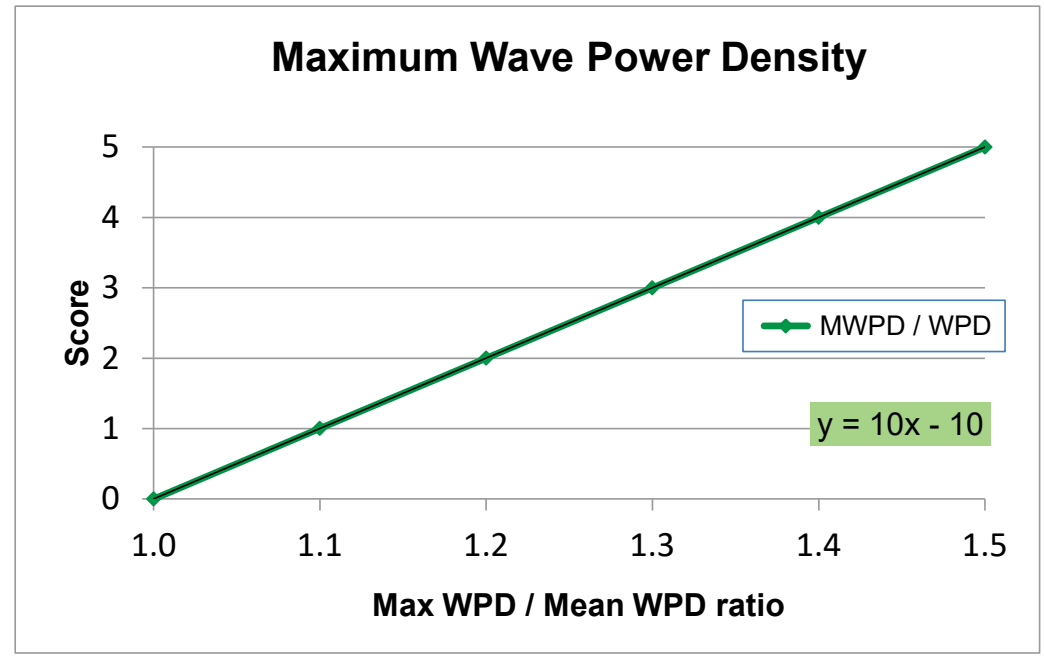

\begin{tabular}{|c|c|}
\hline Max WPD / Mean WPD & Score \\
\hline MxWPD* = MeWPD** & 0 \\
\hline $1<$ MxWPD/MeWPD $<1.1$ & 1 \\
\hline $1.1<$ MxWPD/MeWPD $<1.2$ & 2 \\
\hline $1.2<$ MxWPD/MeWPD $<1.3$ & 3 \\
\hline $1.3<$ MxWPD/WPD $<1.4$ & 4 \\
\hline $1.4<$ MxWPD/MeWPD & 5 \\
\hline $\begin{array}{l}{ }^{*} \mathrm{M} \text { MWPD }=\text { Max WPD; } \\
{ }^{* *} \mathrm{MeWPD}=\mathrm{Mean} \text { WPD }\end{array}$ & \\
\hline
\end{tabular}

Figure 15. Ratio of maximum to mean wave power density scoring and table

\subsubsection{Distance to Wave Resource}

Scoring logic applied:

The closer the DOD base is to the wave resource, the better. Within $500 \mathrm{~m}$ was scored at the maximum, with the score decreasing linearly to 2 miles $(3,200 \mathrm{~m})$ as an estimate of the maximum distance for early adopters. These distances are further than for tidal, with the expectation of larger areas with resource further out to sea leading to larger power generation stations.

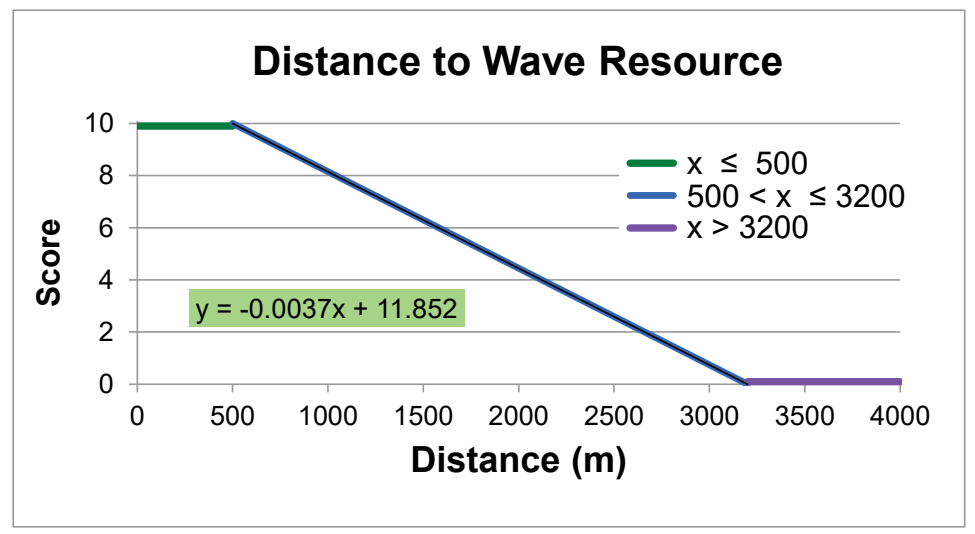

\begin{tabular}{|c|c|}
\hline Distance $(\mathbf{m})$ & Score \\
\hline $0-500$ & 10 \\
\hline $500-3200$ & $-0.0037 x+11.852$ \\
\hline$>3200$ & 0 \\
\hline
\end{tabular}

Figure 16. Distance to area with WPS $>4 \mathrm{~kW} / \mathrm{m}$ minimum 


\subsubsection{Area with WPD $>4 \mathrm{~kW} / \mathrm{m}$}

Scoring logic applied:

Available area with a base amount of wave resource is an important factor, especially for larger bases and MHK systems. The discrete function is an "estimate" made more easily useable with a "curve fit" equation. The difference in scoring points between the discrete, piecewise equation and the logarithmic function is minimal.

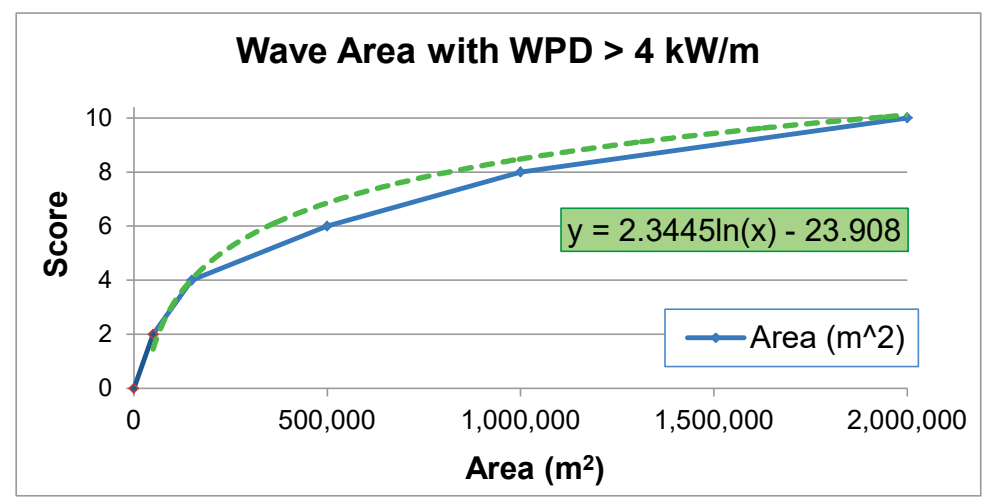

\begin{tabular}{|l|c|}
\hline \multicolumn{1}{|c|}{ Area $\left(\mathbf{m}^{2}\right)$} & Score \\
\hline $0-50,000$ & 0 \\
\hline $50,000-150,000$ & 2 \\
\hline $150,000-500,000$ & 4 \\
\hline $500,000-1,000,000$ & 6 \\
\hline $1,000,000-2,000,000$ & 8 \\
\hline$>2,000,000$ & 10 \\
\hline
\end{tabular}

Figure 17. Area with WPD $>4 \mathrm{~kW} / \mathrm{m}$

The environmental, distance to the substation, base load and cost of electricity scoring equations were the same as used in the tidal energy scoring and are not repeated here.

\subsection{Screening Results}

After the screening criteria were applied and the list of viable sites considerably narrowed, a more manual qualitative filter was applied to compensate for some of the unintended impractical results. For example, a site may have been selected due to the resource's proximity to the facility (e.g., 3 miles); however, closer examination reveals that the site is actually a recruiting office located 3 miles inland from shore. Realistically, this does not appear to be a viable candidate even though it met the initial screening criteria of being with a 5-mile radius of the base to the resource. In other cases, the opposite occurred-where the "center" of the base or a particular building is used to determine the distance to the resource even though a portion of the base is geographically much closer to the resource. The database was not designed for these types of queries, and manual filtering was applied as needed.

The preliminary results of the GIS screening were sites that met the screening criteria within each type of MHK resource. These site lists were provided to the Army, Coast Guard, and Air Force to help down-select to two facilities to be visited by NREL and the DOD RE leads for further investigation into the deployability of MHK devices at DOD bases. The tables in sections 4.4.1 and 4.4.6 show the scoring results, applying the equations in sections 4.3.1 and 4.3.2. 


\subsubsection{Potential Coast Guard Tidal Current Sites at 1-Mile Radius}

Table 7 shows the preliminary list of Coast Guard bases with the highest potential based on the screening criteria applied for deployable projects using tidal current MHK technology. Note that the Coast Guard stations are generally much smaller than military bases, so the electric loads will show fairly low scores for all Coast Guard facilities relative to the Army and Air Force.

Table 7. Coast Guard Sites with High Potential for Tidal Current MHK Projects at 1-Mile Radius

\begin{tabular}{|c|c|c|c|c|c|c|c|c|c|c|c|}
\hline Base Name & State & DOD Branch & $\begin{array}{c}\text { Area-weighted } \\
\text { Mean TCS }>0.6 \\
\mathrm{~m} / \mathrm{s} \text { to } 150 \mathrm{~m} \\
\text { Depth }\end{array}$ & $\begin{array}{l}\text { Maximum } \\
\text { TCS }>0.6 \mathrm{~m} / \mathrm{s} \\
\text { to } 150 \mathrm{~m} \\
\text { Depth }\end{array}$ & $\begin{array}{c}\text { Area with } \\
\text { TCS }>0.6 \mathrm{~m} / \mathrm{s} \\
\text { to } 150 \mathrm{~m} \\
\text { Depth }\end{array}$ & $\begin{array}{c}\text { Distance to } \\
\text { Area } w / \text { TCS } \\
>0.6 \mathrm{~m} / \mathrm{s} \text { to } \\
150 \mathrm{~m}\end{array}$ & $\begin{array}{l}\text { Distance } \\
\text { to Sub- } \\
\text { station }\end{array}$ & $\begin{array}{c}\text { Total } \\
\text { Exclu- } \\
\text { sions }\end{array}$ & $\begin{array}{c}\text { Electric } \\
\text { Load }\end{array}$ & $\begin{array}{l}\text { Cost of } \\
\text { Elec- } \\
\text { tricity }\end{array}$ & $\begin{array}{l}\text { Total } \\
\text { Points }\end{array}$ \\
\hline Name & ST & DOD & (pts) & (pts) & (pts) & (pts) & (pts) & (pts) & (pts) & (pts) & (pts) \\
\hline USCG Station Portsmouth Harbor & $\mathrm{NH}$ & Coast Guard & 3.6 & 5.0 & 9.0 & 10.0 & 9.1 & 10.0 & 1.2 & 3.0 & 50.9 \\
\hline Coast Guard, United States & MA & Coast Guard & 3.3 & 5.0 & 10.0 & 8.8 & 1.6 & 10.0 & 4.4 & 3.2 & 46.2 \\
\hline US Coast Guard Station Jones Beach & NY & Coast Guard & 3.4 & 3.0 & 9.0 & 6.2 & 0.0 & 10.0 & 3.2 & 3.1 & 37.9 \\
\hline US Coast Guard Station Sandy Hook & NJ & Coast Guard & 2.1 & 1.0 & 7.3 & 7.8 & 4.0 & 8.0 & 4.4 & 2.6 & 37.2 \\
\hline US Coast Guard Station Fire Island & NY & Coast Guard & 2.2 & 1.0 & 8.3 & 9.3 & 0.0 & 8.0 & 3.2 & 3.1 & 35.2 \\
\hline USCG Sector Sf-Yerba Buena Island & CA & Coast Guard & 2.0 & 1.0 & 7.8 & 8.6 & 0.0 & 6.0 & 3.2 & 3.1 & 31.8 \\
\hline
\end{tabular}




\subsubsection{Potential Army Tidal Current Sites at 1-Mile Radius}

Table 8 shows the preliminary list of Army bases with the highest potential based on the screening criteria applied for deployable projects using tidal current MHK technology.

Table 8. Army Sites with High Potential for Tidal Current MHK Projects at 1-Mile Radius

\begin{tabular}{|c|c|c|c|c|c|c|c|c|c|c|c|}
\hline Base Name & State & DOD Branch & $\begin{array}{c}\text { Area-weighted } \\
\text { Mean TCS >0.6 } \\
\text { m/s to } 150 \mathrm{~m} \\
\text { Depth }\end{array}$ & $\begin{array}{c}\text { Maximum } \\
\text { TCS }>0.6 \mathrm{~m} / \mathrm{s} \\
\text { to } 150 \mathrm{~m} \\
\text { Depth }\end{array}$ & $\begin{array}{c}\text { Area with } \\
\text { TCS }>0.6 \mathrm{~m} / \mathrm{s} \\
\text { to } 150 \mathrm{~m} \\
\text { Depth }\end{array}$ & $\begin{array}{c}\text { Distance to } \\
\text { Area w/ TCS } \\
>0.6 \mathrm{~m} / \mathrm{s} \text { to } \\
150 \mathrm{~m}\end{array}$ & $\begin{array}{l}\text { Distance } \\
\text { to Sub- } \\
\text { station }\end{array}$ & $\begin{array}{c}\text { Total } \\
\text { Exclu- } \\
\text { sions }\end{array}$ & $\begin{array}{c}\text { Electric } \\
\text { Load }\end{array}$ & $\begin{array}{l}\text { Cost of } \\
\text { Elec- } \\
\text { tricity }\end{array}$ & $\begin{array}{l}\text { Total } \\
\text { Points }\end{array}$ \\
\hline Name & ST & DOD & (pts) & (pts) & (pts) & (pts) & (pts) & (pts) & (pts) & (pts) & (pts) \\
\hline NG Dillingham Armory & AK & Army Guard & 4.2 & 4.0 & 10.0 & 7.6 & 5.2 & 10.0 & 3.2 & 3.5 & 47.7 \\
\hline MTA Camp Edwards & MA & Army Guard & 2.9 & 1.0 & 9.2 & 10.0 & 2.1 & 8.0 & 7.9 & 4.0 & 45.1 \\
\hline NG Buzzards Bay & MA & Army Guard & 2.9 & 1.0 & 7.6 & 6.6 & 9.9 & 10.0 & 3.2 & 3.2 & 44.5 \\
\hline Whittier Anchorage Pipeline & AK & Army Active & 2.9 & 4.0 & 10.0 & 9.7 & 2.7 & 10.0 & 1.2 & 3.5 & 44.0 \\
\hline NG Anacortes & WA & Army Guard & 2.7 & 5.0 & 5.9 & 4.7 & 10.0 & 6.0 & 4.4 & 1.6 & 40.5 \\
\hline NG Wrangell Armory & AK & Army Guard & 2.5 & 1.0 & 6.6 & 4.0 & 8.1 & 10.0 & 3.2 & 3.5 & 38.9 \\
\hline NG Portsmouth Readiness Center & $\mathrm{NH}$ & Army Guard & 4.1 & 5.0 & 9.5 & 3.7 & 0.0 & 10.0 & 3.2 & 3.0 & 38.5 \\
\hline NG Petersburg Armory & AK & Army Guard & 9.2 & 1.0 & 8.5 & 3.0 & 0.0 & 10.0 & 3.2 & 3.5 & 38.4 \\
\hline Haines Terminal & AK & Army Active & 5.0 & 1.0 & 7.5 & 3.3 & 0.7 & 10.0 & 5.9 & 3.5 & 37.0 \\
\hline NG Juneau AAOF & AK & Army Guard & 2.3 & 1.0 & 7.2 & 2.1 & 6.4 & 10.0 & 4.4 & 3.5 & 36.9 \\
\hline NG St Augustine, St Francis Barracks & $\mathrm{FL}$ & Army Guard & 2.2 & 1.0 & 9.1 & 10.0 & 5.6 & 2.0 & 4.4 & 1.9 & 36.2 \\
\hline NG Newport Armory & OR & Army Guard & 2.3 & 1.0 & 9.5 & 4.5 & 7.9 & 6.0 & 3.2 & 1.8 & 36.2 \\
\hline NG Bronx Readiness Center & NY & Army Guard & 3.5 & 1.0 & 3.2 & 1.5 & 10.0 & 10.0 & 3.2 & 3.1 & 35.5 \\
\hline Fort Worden Cemetery & WA & Army Active & 2.7 & 2.0 & 10.0 & 9.6 & 0.0 & 4.0 & 3.2 & 1.6 & 33.2 \\
\hline NG Gov Bacon Health Ctr & $\overline{D L}$ & Army Guard & 2.0 & 1.0 & 8.2 & 2.7 & 3.9 & 10.0 & 3.2 & 2.1 & 33.1 \\
\hline NG Park Ave Readiness Center & NY & Army Guard & 2.9 & 1.0 & 8.0 & 4.3 & 0.0 & 10.0 & 3.2 & 3.1 & 32.4 \\
\hline NG St Augustine, USP\&FO & $\mathrm{FL}$ & Army Guard & 2.2 & 1.0 & 9.1 & 10.0 & 0.0 & 2.0 & 4.4 & 1.9 & 30.7 \\
\hline AFRC Daytona Beach & $\mathrm{FL}$ & Army Guard & 2.2 & 1.0 & 7.6 & 10.0 & 0.0 & 2.0 & 3.2 & 1.9 & 28.0 \\
\hline Sp Forces Site Key West & $\mathrm{FL}$ & Army Active & 2.5 & 2.0 & 9.8 & 5.4 & 0.0 & 0.0 & 5.9 & 1.9 & 27.5 \\
\hline
\end{tabular}




\subsubsection{Potential Air Force Tidal Current Sites at 1-Mile Radius}

Table 9 shows the preliminary list of Air Force bases with the highest potential based on the screening criteria applied for deployable projects using tidal current MHK technology.

Table 9. Air Force Sites with High Potential for Tidal Current MHK Projects at 1-Mile Radius

\begin{tabular}{|c|c|c|c|c|c|c|c|c|c|c|c|}
\hline Base Name & State & DOD Branch & \begin{tabular}{|c|} 
Area-weighted \\
Mean TCS >0.6 \\
$\mathrm{m} / \mathrm{s}$ to $150 \mathrm{~m}$ \\
Depth
\end{tabular} & $\begin{array}{c}\text { Maximum } \\
\text { TCS }>0.6 \mathrm{~m} / \mathrm{s} \\
\text { to } 150 \mathrm{~m} \\
\text { Depth }\end{array}$ & $\begin{array}{c}\text { Area with } \\
\text { TCS }>0.6 \mathrm{~m} / \mathrm{s} \\
\text { to } 150 \mathrm{~m} \\
\text { Depth }\end{array}$ & \begin{tabular}{|c|} 
Distance to \\
Area w/ TCS \\
$>0.6 \mathrm{~m} / \mathrm{s}$ to \\
$150 \mathrm{~m}$
\end{tabular} & $\begin{array}{l}\text { Distance } \\
\text { to Sub- } \\
\text { station }\end{array}$ & $\begin{array}{c}\text { Total } \\
\text { Exclu- } \\
\text { sions }\end{array}$ & $\begin{array}{c}\text { Electric } \\
\text { Load }\end{array}$ & $\begin{array}{l}\text { Cost of } \\
\text { Elec- } \\
\text { tricity }\end{array}$ & $\begin{array}{c}\text { Total } \\
\text { Points }\end{array}$ \\
\hline Name & ST & DOD & (pts) & (pts) & (pts) & (pts) & (pts) & (pts) & (pts) & (pts) & (pts) \\
\hline Fort Richardson & AK & AF Active & 3.3 & 4.0 & 10.0 & 10.0 & 9.8 & 10.0 & 10.0 & 3.5 & 60.5 \\
\hline Elmendorf AFB & AK & AF Active & 3.2 & 5.0 & 10.0 & 10.0 & 0.8 & 10.0 & 10.0 & 3.5 & 52.4 \\
\hline Newington Defense Fuel Support Point & $\mathrm{NH}$ & AF Active & 3.8 & 5.0 & 10.0 & 10.0 & 0.0 & 10.0 & 3.2 & 3.0 & 45.0 \\
\hline Ipswich Antenna Farm Annex & MA & AF Active & 2.7 & 4.0 & 10.0 & 9.9 & 3.5 & 8.0 & 3.2 & 3.2 & 44.5 \\
\hline Eglin AFB & $\mathrm{FL}$ & AF Active & 2.6 & 3.0 & 10.0 & 10.0 & 0.1 & 6.0 & 10.0 & 1.9 & 43.6 \\
\hline Cape Cod AS & MA & AF Active & 2.9 & 1.0 & 8.0 & 7.0 & 0.0 & 10.0 & 7.9 & 3.2 & 39.9 \\
\hline Cape Canaveral AFS & $\mathrm{FL}$ & AF Active & 2.1 & 1.0 & 7.6 & 9.8 & 1.9 & 0.0 & 10.0 & 1.9 & 34.2 \\
\hline Ship Shoal Island & $\mathrm{VA}$ & AF Active & 2.5 & 1.0 & 7.7 & 2.6 & 3.8 & 10.0 & 3.2 & 1.6 & 32.5 \\
\hline Cudjoe Key AFS & $\mathrm{FL}$ & AF Active & 2.6 & 1.0 & 8.2 & 2.8 & 8.0 & 0.0 & 3.2 & 1.9 & 27.7 \\
\hline
\end{tabular}

The primary applied screen — the distance from the base — was increased from a 1-mile to a 5-mile radius to cast a wider net on future potential. By doing so, more sites are included that meet the minimum tidal resource threshold and the resource potential expanded considerably in many cases, as did distances and number of exclusions. The case could readily be made that the scoring equations or the weighting should be adjusted because of the altered criteria. The same equations and weighting were used in these analyses to better highlight the difference in relative scoring by simply increasing the search space for area of the resource and area of the exclusions. The results can be seen in the following three tables. 


\subsubsection{Potential Coast Guard Tidal Current Sites at 5-Mile Radius}

Table 10 shows the preliminary list of Coast Guard bases with the highest potential based on the screening criteria applied for deployable projects using tidal current MHK technology. Note that the Coast Guard stations are generally much smaller than military bases, so the electric loads will show fairly low scores for all Coast Guard facilities relative to the Army and Air Force.

Table 10. Coast Guard Sites with High Potential for Tidal Current MHK Projects at 5-Mile Radius

\begin{tabular}{|c|c|c|c|c|c|c|c|c|c|c|c|}
\hline Base Name & State & DOD Branch & $\begin{array}{c}\text { Area-weighted } \\
\text { Mean TCS >0.6 } \\
\mathrm{m} / \mathrm{s} \text { to } 150 \mathrm{~m} \\
\text { Depth }\end{array}$ & \begin{tabular}{|} 
Maximum \\
TCS $>0.6 \mathrm{~m} / \mathrm{s}$ \\
to $150 \mathrm{~m}$ \\
Depth
\end{tabular} & $\begin{array}{c}\text { Area with } \\
\text { TCS }>0.6 \mathrm{~m} / \mathrm{s} \\
\text { to } 150 \mathrm{~m} \\
\text { Depth }\end{array}$ & $\begin{array}{c}\text { Distance to Area } \\
\text { w/ TCS }>0.6 \mathrm{~m} / \mathrm{s} \\
\text { to } 150 \mathrm{~m}\end{array}$ & $\begin{array}{c}\text { Distance } \\
\text { to Sub- } \\
\text { station }\end{array}$ & $\begin{array}{l}\text { Total } \\
\text { Exclu- } \\
\text { sions }\end{array}$ & $\begin{array}{c}\text { Electric } \\
\text { Load }\end{array}$ & $\begin{array}{l}\text { Cost of } \\
\text { Elec- } \\
\text { tricity }\end{array}$ & $\begin{array}{l}\text { Total } \\
\text { Points }\end{array}$ \\
\hline Name & ST & DOD & (pts) & (pts) & (pts) & (pts) & (pts) & (pts) & (pts) & (pts) & (pts) \\
\hline USCG Station Portsmouth Harbor & $\mathrm{NH}$ & Coast Guard & 4.1 & 5.0 & 10.0 & 10.0 & 9.1 & 10.0 & 1.2 & 3.0 & 52.4 \\
\hline US Coast Guard, Ocean City & $\mathrm{MD}$ & Coast Guard & 3.2 & 5.0 & 10.0 & 8.8 & 1.6 & 10.0 & 5.3 & 3.2 & 47.0 \\
\hline US Coast Guard Station Sandy Hook & NJ & Coast Guard & 2.9 & 3.0 & 10.0 & 7.8 & 4.0 & 8.0 & 4.4 & 2.6 & 42.7 \\
\hline US Coast Guard Training Center Cape May & NJ & Coast Guard & 2.6 & 5.0 & 10.0 & 0.0 & 7.1 & 6.0 & 7.3 & 2.6 & 40.6 \\
\hline USCGSector Sf-Yerba Buena Island & CA & Coast Guard & 2.2 & 2.0 & 10.0 & 8.6 & 0.0 & 10.0 & 3.2 & 3.1 & 39.2 \\
\hline US Coast Guard Station Fire Island & NY & Coast Guard & 3.0 & 4.0 & 10.0 & 9.3 & 0.0 & 4.0 & 3.2 & 3.1 & 36.6 \\
\hline US Coast Guard Station Jones Beach & NY & Coast Guard & 3.1 & 4.0 & 10.0 & 6.2 & 0.0 & 4.0 & 3.2 & 3.1 & 33.6 \\
\hline US Coast Guard, Martha's Vineyard & MA & Coast Guard & 2.3 & 4.0 & 10.0 & 0.0 & 0.3 & 10.0 & 4.4 & 1.7 & 32.8 \\
\hline US Coast Guard Station Shinnecock & NY & Coast Guard & 4.1 & 2.0 & 7.2 & 0.0 & 0.0 & 10.0 & 3.2 & 3.1 & 29.7 \\
\hline US Coast Guard Reservation & NJ & Coast Guard & 2.5 & 5.0 & 10.0 & 0.0 & 0.0 & 6.0 & 3.2 & 2.6 & 29.3 \\
\hline US Coast Guard Stn Islamorada & $\mathrm{FL}$ & Coast Guard & 3.4 & 3.0 & 10.0 & 0.0 & 4.0 & 0.0 & 3.2 & 1.9 & 25.5 \\
\hline
\end{tabular}




\subsubsection{Potential Army Tidal Current Sites at 5-Mile Radius}

Table 11 shows the preliminary list of Army bases with the highest potential based on the screening criteria applied for deployable projects using tidal current MHK technology.

Table 11. Army Guard Sites with High Potential for Tidal Current MHK Projects at 5-Mile Radius

\begin{tabular}{|c|c|c|c|c|c|c|c|c|c|c|c|}
\hline Base Name & State & DOD Branch & $\begin{array}{c}\text { Area-weighted } \\
\text { Mean TCS >0.6 } \\
\text { m/s to } 150 \mathrm{~m} \\
\text { Depth }\end{array}$ & $\begin{array}{c}\text { Maximum } \\
\text { TCS }>0.6 \mathrm{~m} / \mathrm{s} \\
\text { to } 150 \mathrm{~m} \\
\text { Depth }\end{array}$ & $\begin{array}{c}\text { Area with } \\
\text { TCS }>0.6 \mathrm{~m} / \mathrm{s} \\
\text { to } 150 \mathrm{~m} \\
\text { Depth }\end{array}$ & $\begin{array}{l}\text { Distance to } \\
\text { Area w/ TCS } \\
>0.6 \mathrm{~m} / \mathrm{s} \text { to } \\
150 \mathrm{~m}\end{array}$ & \begin{tabular}{|c} 
Distance \\
to Sub- \\
station
\end{tabular} & $\begin{array}{l}\text { Total } \\
\text { Exclu- } \\
\text { sions }\end{array}$ & $\begin{array}{c}\text { Electric } \\
\text { Load }\end{array}$ & $\begin{array}{c}\text { Cost of } \\
\text { Elec- } \\
\text { tricity }\end{array}$ & $\begin{array}{c}\text { Total } \\
\text { Points }\end{array}$ \\
\hline Name & ST & DOD & (pts) & (pts) & (pts) & (pts) & (pts) & (pts) & (pts) & (pts) & (pts) \\
\hline NG St Augustine, St Francis Barracks & $\mathrm{FL}$ & Army Guard & 2.8 & 4.0 & 10.0 & 10.0 & 5.6 & 10.0 & 3.2 & 1.9 & 47.5 \\
\hline NG Dillingham Armory & AK & Army Guard & 4.0 & 5.0 & 10.0 & 7.6 & 5.2 & 8.0 & 3.2 & 3.5 & 46.5 \\
\hline NG Lexington Ave Readiness Ctr & NY & Army Guard & 3.2 & 5.0 & 10.0 & 0.0 & 9.0 & 10.0 & 1.2 & 3.1 & 41.5 \\
\hline NG Petersburg Armory & AK & Army Guard & 9.2 & 1.0 & 10.0 & 3.0 & 0.0 & 10.0 & 3.2 & 3.5 & 39.9 \\
\hline NG Juneau Armory and FMS & $\mathrm{AK}$ & Army Guard & 2.2 & 2.0 & 10.0 & 0.0 & 7.5 & 10.0 & 3.2 & 3.5 & 38.4 \\
\hline NG Anacortes & WA & Army Guard & 3.6 & 5.0 & 10.0 & 4.7 & 10.0 & 0.0 & 3.2 & 1.6 & 38.2 \\
\hline MTA Camp Edwards & MA & Army Guard & 2.7 & 4.0 & 10.0 & 10.0 & 2.1 & 0.0 & 5.3 & 4.0 & 38.1 \\
\hline NG Jewel Lake Armory & AK & Army Guard & 3.2 & 2.0 & 10.0 & 0.0 & 5.8 & 10.0 & 3.2 & 3.5 & 37.8 \\
\hline NG Buzzards Bay & MA & Army Guard & 2.7 & 2.0 & 10.0 & 6.6 & 9.9 & 0.0 & 3.2 & 3.2 & 37.6 \\
\hline Fort Monmouth Main Post & NJ & Army Active & 2.5 & 5.0 & 9.8 & 0.0 & 3.8 & 8.0 & 5.9 & 2.6 & 37.6 \\
\hline Sp Forces Site Key West & $\mathrm{FL}$ & Army Active & 2.8 & 4.0 & 10.0 & 5.4 & 0.0 & 10.0 & 3.2 & 1.9 & 37.4 \\
\hline NG Cape May & $\mathrm{NJ}$ & Army Guard & 2.7 & 2.0 & 10.0 & 0.0 & 9.6 & 6.0 & 4.4 & 2.6 & 37.3 \\
\hline NG Barnstable & MA & Army Guard & 2.3 & 1.0 & 10.0 & 0.0 & 9.3 & 8.0 & 3.2 & 3.2 & 37.0 \\
\hline Fort Lewis & WA & Army Active & 2.2 & 1.0 & 10.0 & 0.0 & 10.0 & 2.0 & 10.0 & 1.6 & 36.9 \\
\hline NG Atlantic City & NJ & Army Guard & 3.5 & 5.0 & 9.8 & 0.0 & 5.6 & 6.0 & 4.4 & 2.6 & 36.9 \\
\hline NG River Road Training Site & $\mathrm{DL}$ & Army Guard & 2.1 & 1.0 & 10.0 & 0.0 & 10.0 & 8.0 & 3.2 & 2.1 & 36.3 \\
\hline NG Wrangell Armory & AK & Army Guard & 3.3 & 4.0 & 10.0 & 4.0 & 8.1 & 0.0 & 3.2 & 3.5 & 36.1 \\
\hline NG Bremerton & WA & Army Guard & 3.2 & 3.0 & 10.0 & 0.0 & 7.4 & 6.0 & 4.4 & 1.6 & 35.6 \\
\hline NG Falmouth & MA & Army Guard & 3.3 & 5.0 & 10.0 & 0.0 & 4.7 & 6.0 & 3.2 & 3.2 & 35.4 \\
\hline NG Calais Armory & $\mathrm{ME}$ & Army Guard & 6.5 & 5.0 & 10.0 & 0.0 & 0.0 & 10.0 & 1.2 & 2.5 & 35.2 \\
\hline AFRC Daytona Beach & $\mathrm{FL}$ & Army Guard & 2.2 & 1.0 & 7.6 & 10.0 & 0.0 & 8.0 & 4.4 & 1.9 & 35.1 \\
\hline NG Portsmouth Readiness Center & $\mathrm{NH}$ & Army Guard & 3.8 & 5.0 & 10.0 & 3.7 & 0.0 & 6.0 & 3.2 & 3.0 & 34.8 \\
\hline NG Juneau AAOF & AK & Army Guard & 2.2 & 2.0 & 10.0 & 2.1 & 6.4 & 4.0 & 4.4 & 3.5 & 34.6 \\
\hline NG Coos Bay Armory & $\mathrm{OR}$ & Army Guard & 4.1 & 4.0 & 10.0 & 0.0 & 7.1 & 4.0 & 3.2 & 1.8 & 34.2 \\
\hline NG Jersey City & NJ & Army Guard & 2.7 & 4.0 & 10.0 & 0.0 & 0.0 & 10.0 & 4.4 & 2.6 & 33.7 \\
\hline NG Newport Armory & $\mathrm{OR}$ & Army Guard & 2.3 & 1.0 & 9.5 & 4.5 & 7.9 & 2.0 & 3.2 & 1.8 & 32.2 \\
\hline NG Tacoma & WA & Army Guard & 5.0 & 5.0 & 10.0 & 0.0 & 0.0 & 6.0 & 4.4 & 1.6 & 32.1 \\
\hline NG Port Orchard & WA & Army Guard & 3.7 & 4.0 & 10.0 & 0.0 & 4.7 & 4.0 & 3.2 & 1.6 & 31.3 \\
\hline NG Kenai Armory & AK & Army Guard & 2.4 & 2.0 & 10.0 & 0.0 & 0.0 & 10.0 & 3.2 & 3.5 & 31.1 \\
\hline NG Eureka & CA & Army Guard & 3.0 & 3.0 & 10.0 & 0.0 & 3.3 & 4.0 & 4.4 & 3.1 & 30.9 \\
\hline NG Newburyport & MA & Army Guard & 2.8 & 5.0 & 10.0 & 0.0 & 0.0 & 6.0 & 3.2 & 3.2 & 30.2 \\
\hline Haines Terminal & AK & Army Active & 5.0 & 1.0 & 10.0 & 3.3 & 0.7 & 0.0 & 5.9 & 3.5 & 29.4 \\
\hline
\end{tabular}




\subsubsection{Potential Air Force Tidal Current Sites at 5-Mile Radius}

Table 12 shows the preliminary list of Air Force bases with the highest potential based on the screening criteria applied for deployable projects using tidal current MHK technology.

Table 12. Air Force Sites with High Potential for Tidal Current MHK Projects at 5-Mile Radius

\begin{tabular}{|c|c|c|c|c|c|c|c|c|c|c|c|}
\hline Base Name & State & DOD Branch & $\begin{array}{l}\text { Area-weighted } \\
\text { Mean TCS >0.6 } \\
\text { m/s to } 150 \mathrm{~m} \\
\text { Depth }\end{array}$ & \begin{tabular}{|c|} 
Maximum \\
TCS $>0.6 \mathrm{~m} / \mathrm{s}$ \\
to $150 \mathrm{~m}$ \\
Depth
\end{tabular} & \begin{tabular}{|c|} 
Area with \\
TCS $>0.6 \mathrm{~m} / \mathrm{s}$ \\
to $150 \mathrm{~m}$ \\
Depth
\end{tabular} & $\begin{array}{c}\text { Distance to } \\
\text { Area w/ TCS } \\
>0.6 \mathrm{~m} / \mathrm{s} \text { to } \\
150 \mathrm{~m}\end{array}$ & $\begin{array}{l}\text { Distance } \\
\text { to Sub- } \\
\text { station }\end{array}$ & $\begin{array}{c}\text { Total } \\
\text { Exclu- } \\
\text { sions }\end{array}$ & $\begin{array}{c}\text { Electric } \\
\text { Load }\end{array}$ & $\begin{array}{l}\text { Cost of } \\
\text { Elec- } \\
\text { tricity }\end{array}$ & $\begin{array}{l}\text { Total } \\
\text { Points }\end{array}$ \\
\hline Name & ST & DOD & (pts) & (pts) & (pts) & (pts) & (pts) & (pts) & (pts) & (pts) & (pts) \\
\hline Fort Richardson & AK & AF Active & 3.5 & 5.0 & 10.0 & 10.0 & 9.8 & 0.0 & 10.0 & 4.4 & 52.6 \\
\hline Eglin AFB & $\mathrm{FL}$ & AF Active & 2.6 & 3.0 & 10.0 & 10.0 & 0.1 & 10.0 & 10.0 & 1.9 & 47.6 \\
\hline Cape Cod AS & MA & AF Active & 2.8 & 4.0 & 10.0 & 7.0 & 0.0 & 10.0 & 7.9 & 3.2 & 44.8 \\
\hline Ipswich Antenna Farm Annex & MA & AF Active & 2.6 & 4.0 & 10.0 & 9.9 & 3.5 & 8.0 & 3.2 & 3.2 & 44.4 \\
\hline Elmendorf AFB & AK & AF Active & 3.5 & 5.0 & 10.0 & 10.0 & 0.8 & 0.0 & 10.0 & 3.5 & 42.7 \\
\hline Cudjoe Key AFS & $\mathrm{FL}$ & AF Active & 2.6 & 4.0 & 10.0 & 2.8 & 8.0 & 8.0 & 3.2 & 1.9 & 40.4 \\
\hline Cape Newenham Long Range Radar Site & AK & AF Active & 3.5 & 5.0 & 10.0 & 0.0 & 0.0 & 10.0 & 5.9 & 3.5 & 37.9 \\
\hline Newington Defense Fuel Support Point & $\mathrm{NH}$ & AF Active & 3.9 & 5.0 & 10.0 & 10.0 & 0.0 & 0.0 & 3.2 & 3.0 & 35.2 \\
\hline MacDill AFB & $\mathrm{FL}$ & AF Active & 2.0 & 1.0 & 7.0 & 0.0 & 6.9 & 6.0 & 10.0 & 1.9 & 34.8 \\
\hline Cape Canaveral AFS & $\mathrm{FL}$ & AF Active & 2.1 & 1.0 & 7.6 & 9.8 & 1.9 & 0.0 & 10.0 & 1.9 & 34.2 \\
\hline Naknek Recreation Annex \#2 & AK & AF Active & 2.6 & 4.0 & 10.0 & 0.0 & 0.0 & 10.0 & 3.2 & 3.5 & 33.3 \\
\hline Ship Shoal Island & VA & AF Active & 2.3 & 3.0 & 10.0 & 2.6 & 3.8 & 6.0 & 3.2 & 1.6 & 32.6 \\
\hline LWTC, NFAC Site \#1 & CA & AF Active & 2.6 & 1.0 & 7.1 & 0.0 & 8.3 & 6.0 & 4.4 & 3.1 & 32.5 \\
\hline Port Heiden Radio Relay Site & AK & AF Active & 3.0 & 4.0 & 10.0 & 0.0 & 0.8 & 8.0 & 3.2 & 3.5 & 32.5 \\
\hline Hurlburt Field & $\mathrm{FL}$ & AF Active & 2.3 & 1.0 & 3.9 & 0.0 & 10.0 & 8.0 & 5.3 & 1.9 & 32.4 \\
\hline Sagamore Hill Electronics Research Annex & MA & AF Active & 2.4 & 2.0 & 10.0 & 0.0 & 0.0 & 10.0 & 3.2 & 3.2 & 30.8 \\
\hline Clausen Missile Tracking Annex & $\mathrm{FL}$ & AF Active & 2.6 & 3.0 & 10.0 & 0.0 & 0.0 & 8.0 & 3.2 & 1.9 & 28.7 \\
\hline Onizuka AFB & CA & AF Active & 2.6 & 1.0 & 7.1 & 0.0 & 0.0 & 6.0 & 3.2 & 3.1 & 23.0 \\
\hline Port Canaveral Cable Terminal Annex & $\mathrm{FL}$ & AF Active & 2.1 & 1.0 & 7.6 & 4.9 & 0.0 & 0.0 & 3.2 & 1.9 & 20.7 \\
\hline
\end{tabular}




\subsubsection{Potential Coast Guard Wave Energy Sites at 1-Mile Radius}

Table 13 shows the preliminary list of Coast Guard bases with the highest potential based on the screening criteria applied for deployable projects using wave energy MHK technology.

Table 13. Coast Guard Sites with High Potential for Wave Energy MHK Projects at 1-Mile Radius

\begin{tabular}{|c|c|c|c|c|c|c|c|c|c|c|c|}
\hline Base Name & State & DOD Branch & $\begin{array}{c}\text { Mean WPD > } \\
4 \mathrm{~kW} / \mathrm{m} \text { to } \\
150 \mathrm{~m} \text { Depth }\end{array}$ & $\begin{array}{l}\text { Max WPD / } \\
\text { Mean WPD } \\
\text { Ratio }\end{array}$ & $\begin{array}{c}\text { Area with } \\
\text { WPD }>4 \\
\mathrm{~kW} / \mathrm{m} 150 \mathrm{~m} \\
\text { Depth }\end{array}$ & \begin{tabular}{|c|} 
Distance to \\
Area with WPD \\
$>4 \mathrm{~kW} / \mathrm{m}$ to \\
$150 \mathrm{~m}$
\end{tabular} & $\begin{array}{l}\text { Distance } \\
\text { to Sub- } \\
\text { station }\end{array}$ & $\begin{array}{l}\text { Total } \\
\text { Exclu- } \\
\text { sions }\end{array}$ & $\begin{array}{l}\text { Electric } \\
\text { Load }\end{array}$ & $\begin{array}{c}\text { Cost of } \\
\text { Elec- } \\
\text { tricity }\end{array}$ & $\begin{array}{l}\text { Total } \\
\text { Points }\end{array}$ \\
\hline Name & ST & DOD & (pts) & (pts) & (pts) & (pts) & (pts) & (pts) & (pts) & (pts) & (pts) \\
\hline US Coast Guard Reservation, Kaho'Olawe & $\mathrm{HI}$ & Coast Guard & 2.4 & 1.0 & 10.0 & 10.0 & 9.6 & 10.0 & 4.3 & 6.7 & 54.0 \\
\hline Upolu Point Coast Guard Reserve & $\mathrm{HI}$ & Coast Guard & 3.4 & 1.0 & 10.0 & 10.0 & 7.2 & 10.0 & 1.0 & 6.7 & 49.2 \\
\hline
\end{tabular}




\subsubsection{Potential Army Wave Energy Sites at 1-Mile Radius}

Table 14 shows the preliminary list of Army bases with the highest potential based on the screening criteria applied for deployable projects utilizing wave energy MHK technology.

Table 14. Army Sites with High Potential for Wave Energy MHK Projects at 1-Mile Radius

\begin{tabular}{|c|c|c|c|c|c|c|c|c|c|c|c|}
\hline Base Name & State & DOD Branch & $\begin{array}{c}\text { Mean WPD > } \\
4 \mathrm{~kW} / \mathrm{m} \text { to } \\
150 \mathrm{~m} \text { Depth }\end{array}$ & $\begin{array}{l}\text { Max WPD / } \\
\text { Mean WPD } \\
\text { Ratio }\end{array}$ & $\begin{array}{c}\text { Area with } \\
\text { WPD >4 } \\
k W / \mathrm{m} \mathrm{150m} \\
\text { Depth }\end{array}$ & $\begin{array}{c}\text { Distance to } \\
\text { Area with WPD } \\
>4 \mathrm{~kW} / \mathrm{m} \text { to } \\
150 \mathrm{~m}\end{array}$ & $\begin{array}{l}\text { Distance } \\
\text { to Sub- } \\
\text { station }\end{array}$ & $\begin{array}{l}\text { Total } \\
\text { Exclu- } \\
\text { sions }\end{array}$ & $\begin{array}{l}\text { Electric } \\
\text { Load }\end{array}$ & $\begin{array}{l}\text { Cost of } \\
\text { Elec- } \\
\text { tricity }\end{array}$ & $\begin{array}{l}\text { Total } \\
\text { Points }\end{array}$ \\
\hline Name & ST & DOD & (pts) & (pts) & (pts) & (pts) & (pts) & (pts) & (pts) & (pts) & (pts) \\
\hline Fort Ord & CA & Army Active & 7.9 & 1.0 & 10.0 & 10.0 & 7.3 & 10.0 & 3.1 & 3.9 & 53.1 \\
\hline NG Hanapepe & $\mathrm{HI}$ & Army Guard & 2.6 & 1.0 & 10.0 & 9.3 & 10.0 & 10.0 & 1.0 & 6.7 & 50.6 \\
\hline NG Newport Airport Property & OR & Army Guard & 10.0 & 1.0 & 10.0 & 10.0 & 4.3 & 10.0 & 3.1 & 2.2 & 50.5 \\
\hline Dillingham Mil Res & $\mathrm{HI}$ & Army Active & 5.0 & 1.0 & 10.0 & 10.0 & 4.7 & 10.0 & 3.1 & 6.7 & 50.4 \\
\hline NG Newport Armory & $\mathrm{OR}$ & Army Guard & 10.0 & 1.0 & 10.0 & 10.0 & 3.6 & 10.0 & 3.1 & 2.2 & 49.9 \\
\hline MTA Camp Rilea & $\mathrm{OR}$ & Army Guard & 9.3 & 1.0 & 10.0 & 10.0 & 0.0 & 10.0 & 6.4 & 2.2 & 48.9 \\
\hline Wailuku USARC & $\mathrm{HI}$ & Army Reserve & 3.0 & 1.0 & 6.7 & 7.9 & 9.2 & 10.0 & 3.1 & 6.7 & 47.6 \\
\hline NG San Jose Malech & $\mathrm{CA}$ & Army Guard & 5.7 & 1.0 & 6.3 & 7.0 & 10.0 & 10.0 & 3.1 & 3.9 & 47.0 \\
\hline Mokuleia Army Beach & $\mathrm{HI}$ & Army Active & 5.9 & 1.0 & 10.0 & 10.0 & 0.0 & 10.0 & 1.0 & 6.7 & 44.6 \\
\hline Kahuku Training Area & $\mathrm{HI}$ & Army Active & 8.1 & 4.0 & 10.0 & 10.0 & 0.0 & 4.0 & 1.0 & 6.7 & 43.8 \\
\hline NG San Francisco & CA & Army Guard & 5.7 & 1.0 & 10.0 & 10.0 & 0.0 & 10.0 & 3.1 & 3.9 & 43.7 \\
\hline Makua Mil Reserve & $\mathrm{HI}$ & Army Active & 3.8 & 1.0 & 10.0 & 10.0 & 0.0 & 10.0 & 1.0 & 6.7 & 42.5 \\
\hline Moss Landing LTA & CA & Army Reserve & 3.6 & 1.0 & 10.0 & 10.0 & 0.0 & 10.0 & 3.1 & 3.9 & 41.5 \\
\hline Fort Buchanan & $\mathrm{PR}$ & Army Reserve & 2.3 & 2.0 & 10.0 & 9.3 & 0.0 & 10.0 & 5.8 & 4.5 & 43.9 \\
\hline NG Hangar 21 Readiness Center & PR & Army Guard & 2.5 & 1.0 & 10.0 & 10.0 & 0.0 & 10.0 & 3.1 & 4.5 & 41.1 \\
\hline NG Army Aviation Support Facility & $\mathrm{PR}$ & Army Guard & 2.3 & 1.0 & 10.0 & 10.0 & 0.0 & 10.0 & 3.1 & 4.5 & 40.9 \\
\hline Ramey USARC/Aquadilla & $\mathrm{PR}$ & Army Reserve & 2.8 & 2.0 & 10.0 & 10.0 & 0.0 & 10.0 & 1.0 & 4.5 & 40.3 \\
\hline NG TS Kekaha WETS LTA & $\mathrm{HI}$ & Army Guard & 4.6 & 4.0 & 9.8 & 7.9 & 0.0 & 6.0 & 1.0 & 6.7 & 40.0 \\
\hline Kawailoa Training Area & $\mathrm{HI}$ & Army Active & 7.0 & 2.0 & 5.5 & 7.5 & 0.0 & 10.0 & 1.0 & 6.7 & 39.7 \\
\hline Waianae-Kai Military Reservation & $\mathrm{HI}$ & Army Active & 2.0 & 1.0 & 7.0 & 7.3 & 1.8 & 10.0 & 1.0 & 6.7 & 36.7 \\
\hline NG Regional Training Institute & $\mathrm{HI}$ & Army Guard & 4.2 & 1.0 & 0.4 & 6.1 & 0.3 & 10.0 & 3.1 & 6.7 & 31.7 \\
\hline NG Aguadilla Readiness Center & PR & Army Guard & 3.1 & 1.0 & 2.9 & 6.3 & 0.0 & 10.0 & 3.1 & 4.5 & 30.9 \\
\hline
\end{tabular}




\subsubsection{Potential Air Force Wave Energy Sites at 1-Mile Radius}

Table 15 shows the preliminary list of Air Force bases with the highest potential based on the screening criteria applied for deployable projects using wave energy MHK.

Table 15. Air Force Sites with High Potential for Wave Energy MHK Projects at 1-Mile Radius

\begin{tabular}{|c|c|c|c|c|c|c|c|c|c|c|c|}
\hline Base Name & State & DOD Branch & $\begin{array}{c}\text { Mean WPD > } \\
4 \mathrm{~kW} / \mathrm{m} \text { to } \\
150 \mathrm{~m} \text { Depth }\end{array}$ & $\begin{array}{c}\text { Max WPD / } \\
\text { Mean WPD } \\
\text { Ratio }\end{array}$ & $\begin{array}{c}\text { Area with } \\
\text { WPD }>4 \\
k W / m 150 m \\
\text { Depth }\end{array}$ & \begin{tabular}{|c|} 
Distance to \\
Area with WPD \\
$>4 \mathrm{~kW} / \mathrm{m}$ to \\
$150 \mathrm{~m}$
\end{tabular} & $\begin{array}{c}\text { Distance } \\
\text { to Sub- } \\
\text { station }\end{array}$ & $\begin{array}{c}\text { Total } \\
\text { Exclu- } \\
\text { sions }\end{array}$ & $\begin{array}{c}\text { Electric } \\
\text { Load }\end{array}$ & $\begin{array}{l}\text { Cost of } \\
\text { Elec- } \\
\text { tricity }\end{array}$ & $\begin{array}{l}\text { Total } \\
\text { Points }\end{array}$ \\
\hline Name & ST & DOD & (pts) & (pts) & (pts) & (pts) & (pts) & (pts) & (pts) & (pts) & (pts) \\
\hline Punamano AFS & $\mathrm{HI}$ & AF Active & 10.0 & 1.0 & 8.8 & 8.2 & 7.4 & 10.0 & 3.1 & 6.7 & 55.1 \\
\hline Vandenberg AFB & CA & AF Active & 9.4 & 4.0 & 10.0 & 10.0 & 10.0 & 2.0 & 10.0 & 3.9 & 59.3 \\
\hline Pillar Point AFS & CA & AF Active & 7.3 & 2.0 & 10.0 & 10.0 & 7.5 & 10.0 & 3.1 & 3.9 & 53.8 \\
\hline Vandenberg Pt Arguello MTKO3 & CA & AF Active & 10.0 & 1.0 & 10.0 & 10.0 & 2.7 & 10.0 & 5.8 & 3.9 & 53.4 \\
\hline Eareckson AS & AK & AF Active & 10.0 & 5.0 & 10.0 & 10.0 & 0.0 & 8.0 & 9.9 & 4.4 & 57.2 \\
\hline Ramey AF Solar Observatory Research Site & $\mathrm{PR}$ & AF Active & 3.1 & 1.0 & 10.0 & 10.0 & 10.0 & 10.0 & 3.1 & 4.5 & 51.7 \\
\hline Bellows AFS & $\mathrm{HI}$ & AF Active & 5.1 & 3.0 & 10.0 & 10.0 & 6.3 & 6.0 & 3.1 & 6.7 & 50.1 \\
\hline Punta Salinas Radar Site & $\mathrm{PR}$ & AF Guard & 2.3 & 1.0 & 10.0 & 10.0 & 8.5 & 10.0 & 3.1 & 4.5 & 49.4 \\
\hline Luis Munoz Marin IAP & $P R$ & AF Guard & 2.7 & 1.0 & 10.0 & 10.0 & 10.0 & 8.0 & 3.1 & 4.5 & 49.3 \\
\hline Kaena Point Satellite Tracking Station & $\mathrm{HI}$ & AF Active & 5.3 & 3.0 & 10.0 & 10.0 & 0.0 & 10.0 & 1.0 & 6.7 & 46.0 \\
\hline Attu Research Site & $\mathrm{AK}$ & AF Active & 5.0 & 2.0 & 10.0 & 10.0 & 0.0 & 10.0 & 4.3 & 4.4 & 45.7 \\
\hline Kahului Communications Station & $\mathrm{HI}$ & AF Guard & 3.2 & 1.0 & 10.0 & 10.0 & 0.0 & 10.0 & 3.1 & 6.7 & 44.0 \\
\hline Nikolski Radio Relay Site & $\mathrm{AK}$ & AF Active & 4.8 & 1.0 & 10.0 & 10.0 & 0.0 & 10.0 & 3.1 & 4.4 & 43.2 \\
\hline Mill Valley BCN & CA & AF Active & 3.5 & 1.0 & 8.6 & 8.1 & 1.1 & 10.0 & 3.1 & 3.9 & 39.3 \\
\hline
\end{tabular}




\subsubsection{Potential Coast Guard Wave Energy Sites at 5-Mile Radius}

Table 16 shows the preliminary list of Coast Guard bases with the highest potential based on the screening criteria applied for deployable projects using wave energy MHK technology.

Table 16. Coast Guard Sites with High Potential for Wave Energy MHK Projects at 5-Mile Radius

\begin{tabular}{|c|c|c|c|c|c|c|c|c|c|c|c|}
\hline Base Name & State & DOD Branch & $\begin{array}{c}\text { Mean WPD > } \\
4 \mathrm{~kW} / \mathrm{m} \text { to } \\
150 \mathrm{~m} \text { Depth }\end{array}$ & $\begin{array}{l}\text { Max WPD / } \\
\text { Mean WPD } \\
\text { Ratio }\end{array}$ & $\begin{array}{c}\text { Area with } \\
\text { WPD }>4 \\
k W / m 150 m \\
\text { Depth }\end{array}$ & \begin{tabular}{|c|} 
Distance to \\
Area with \\
WPD $>4 \mathrm{~kW} / \mathrm{m}$ \\
to $150 \mathrm{~m}$
\end{tabular} & $\begin{array}{l}\text { Distance } \\
\text { to Sub- } \\
\text { station }\end{array}$ & $\begin{array}{l}\text { Total } \\
\text { Exclu- } \\
\text { sions }\end{array}$ & $\begin{array}{l}\text { Electric } \\
\text { Load }\end{array}$ & $\begin{array}{l}\text { Cost of } \\
\text { Elec- } \\
\text { tricity }\end{array}$ & $\begin{array}{l}\text { Total } \\
\text { Points }\end{array}$ \\
\hline Name & ST & DOD & (pts) & (pts) & (pts) & (pts) & (pts) & (pts) & (pts) & (pts) & (pts) \\
\hline Upolu Point Coast Guard Reserve & $\mathrm{HI}$ & Coast Guard & 3.6 & 5.0 & 10.0 & 10.0 & 7.2 & 10.0 & 3.1 & 6.7 & 55.6 \\
\hline US Coast Guard Reservation, Kaho'Olawe & $\mathrm{HI}$ & Coast Guard & 2.4 & 2.0 & 10.0 & 10.0 & 9.6 & 10.0 & 3.1 & 6.7 & 53.8 \\
\hline Coast Guard Exchange System, Astoria & $\mathrm{OR}$ & Coast Guard & 9.3 & 4.0 & 10.0 & 0.0 & 8.5 & 6.0 & 3.1 & 2.2 & 43.1 \\
\hline Coast Guard Reservation & $\mathrm{CA}$ & Coast Guard & 7.4 & 5.0 & 10.0 & 5.8 & 0.0 & 4.0 & 3.1 & 3.9 & 39.2 \\
\hline US Coast Guard, Westhampton & NY & Coast Guard & 2.0 & 1.0 & 10.0 & 0.0 & 8.8 & 10.0 & 3.1 & 3.8 & 38.7 \\
\hline US Coast Guard Station Shinnecock & NY & Coast Guard & 2.2 & 1.0 & 10.0 & 5.9 & 0.0 & 10.0 & 3.1 & 3.8 & 35.9 \\
\hline US Coast Guard, Martha's Vineyard & MA & Coast Guard & 2.3 & 1.0 & 10.0 & 0.0 & 0.0 & 10.0 & 6.4 & 3.9 & 33.7 \\
\hline Block Island Coast Guard Station & $\mathrm{RI}$ & Coast Guard & 2.2 & 1.0 & 10.0 & 1.0 & 4.8 & 2.0 & 3.1 & 3.9 & 28.0 \\
\hline
\end{tabular}

\subsubsection{Potential Army Wave Energy Sites at 5-Mile Radius}

Table 17 shows the preliminary list of Army bases with the highest potential based on the screening criteria applied for deployable projects using wave energy MHK technology. 
Table 17. Army Sites with High Potential for Wave Energy MHK Projects at 5-Mile Radius

\begin{tabular}{|c|c|c|c|c|c|c|c|c|c|c|c|}
\hline Base Name & State & DOD Branch & $\begin{array}{c}\text { Mean WPD > } \\
4 \mathrm{~kW} / \mathrm{m} \text { to } \\
150 \mathrm{~m} \text { Depth }\end{array}$ & $\begin{array}{c}\text { Max WPD / } \\
\text { Mean WPD } \\
\text { Ratio }\end{array}$ & \begin{tabular}{|c|} 
Area with \\
WPD $>4$ \\
$k W / m$ 150m \\
Depth
\end{tabular} & \begin{tabular}{|c|} 
Distance to \\
Area with \\
WPD $>4 \mathrm{~kW} / \mathrm{m}$ \\
to $150 \mathrm{~m}$
\end{tabular} & $\begin{array}{c}\text { Distance } \\
\text { to Sub- } \\
\text { station }\end{array}$ & $\begin{array}{l}\text { Total } \\
\text { Exclu- } \\
\text { sions }\end{array}$ & $\begin{array}{l}\text { Electric } \\
\text { Load }\end{array}$ & $\begin{array}{l}\text { Cost of } \\
\text { Elec- } \\
\text { tricity }\end{array}$ & $\begin{array}{l}\text { Total } \\
\text { Points }\end{array}$ \\
\hline Name & ST & DOD & (pts) & (pts) & (pts) & (pts) & (pts) & (pts) & (pts) & (pts) & (pts) \\
\hline NG Hanapepe & $\mathrm{HI}$ & Army Guard & 2.6 & 5.0 & 10.0 & 9.3 & 10.0 & 10.0 & 3.1 & 6.7 & 56.8 \\
\hline Dillingham Mil Res & $\mathrm{HI}$ & Army Active & 5.5 & 5.0 & 10.0 & 10.0 & 4.7 & 8.0 & 4.3 & 6.7 & 54.2 \\
\hline NG Kapaa & $\mathrm{HI}$ & Army Guard & 7.3 & 2.0 & 10.0 & 4.6 & 10.0 & 10.0 & 3.1 & 6.7 & 53.7 \\
\hline Wailuku USARC & $\mathrm{HI}$ & Army Reserve & 3.0 & 2.0 & 10.0 & 7.9 & 9.2 & 10.0 & 3.1 & 6.7 & 51.9 \\
\hline NG Newport Armory & $\mathrm{OR}$ & Army Guard & 10.0 & 3.0 & 10.0 & 10.0 & 3.6 & 10.0 & 3.1 & 2.2 & 51.9 \\
\hline Fort Ord & CA & Army Active & 8.1 & 3.0 & 10.0 & 10.0 & 7.3 & 6.0 & 3.1 & 3.9 & 51.3 \\
\hline NG San Jose Malech & $\mathrm{CA}$ & Army Guard & 5.8 & 4.0 & 10.0 & 7.0 & 10.0 & 6.0 & 4.3 & 3.9 & 51.0 \\
\hline Kawailoa Training Area & $\mathrm{HI}$ & Army Active & 7.6 & 5.0 & 10.0 & 7.5 & 0.0 & 8.0 & 5.8 & 6.7 & 50.7 \\
\hline NG Newport Airport Property & OR & Army Guard & 10.0 & 3.0 & 10.0 & 10.0 & 4.3 & 8.0 & 3.1 & 2.2 & 50.5 \\
\hline NG Hilo AASF 2 & $\mathrm{HI}$ & Army Guard & 5.6 & 4.0 & 10.0 & 3.3 & 7.3 & 10.0 & 3.1 & 6.7 & 50.0 \\
\hline MTA Camp Rilea & $\mathrm{OR}$ & Army Guard & 10.0 & 4.0 & 10.0 & 10.0 & 0.0 & 10.0 & 3.1 & 2.2 & 49.3 \\
\hline Kawaihae Mil Reserve & $\mathrm{HI}$ & Army Active & 3.4 & 5.0 & 10.0 & 0.0 & 9.8 & 10.0 & 3.1 & 6.7 & 48.0 \\
\hline Presidio Of Monterey & $\mathrm{CA}$ & Army Active & 10.0 & 2.0 & 10.0 & 1.5 & 10.0 & 2.0 & 7.9 & 3.9 & 47.4 \\
\hline Fort Hunter Liggett & $\mathrm{CA}$ & Army Reserve & 8.0 & 5.0 & 10.0 & 0.0 & 10.0 & 6.0 & 4.3 & 3.9 & 47.2 \\
\hline Fort Buchanan & $P R$ & Army Reserve & 2.5 & 5.0 & 10.0 & 9.3 & 0.0 & 10.0 & 5.8 & 4.5 & 47.1 \\
\hline Waianae-Kai Military Reservation & $\mathrm{HI}$ & Army Active & 2.9 & 5.0 & 10.0 & 7.3 & 1.8 & 10.0 & 3.1 & 6.7 & 46.8 \\
\hline Mokuleia Army Beach & $\mathrm{HI}$ & Army Active & 5.8 & 5.0 & 10.0 & 10.0 & 0.0 & 6.0 & 3.1 & 6.7 & 46.6 \\
\hline Moss Landing LTA & $\mathrm{CA}$ & Army Reserve & 4.3 & 5.0 & 10.0 & 10.0 & 0.0 & 10.0 & 3.1 & 3.9 & 46.3 \\
\hline NG TS Keaukaha Mil Res & $\mathrm{HI}$ & Army Guard & 5.9 & 4.0 & 10.0 & 10.0 & 0.0 & 8.0 & 1.0 & 6.7 & 45.6 \\
\hline NG San Juan Readiness Center & PR & Army Guard & 2.9 & 5.0 & 10.0 & 10.0 & 0.0 & 10.0 & 3.1 & 4.5 & 45.5 \\
\hline Kahuku Training Area & $\mathrm{HI}$ & Army Active & 9.3 & 4.0 & 10.0 & 10.0 & 0.0 & 2.0 & 3.1 & 6.7 & 45.1 \\
\hline NG San Francisco & $\mathrm{CA}$ & Army Guard & 5.9 & 4.0 & 10.0 & 10.0 & 0.0 & 6.0 & 4.3 & 3.9 & 44.1 \\
\hline Makua Mil Reserve & $\mathrm{HI}$ & Army Active & 5.1 & 5.0 & 10.0 & 10.0 & 0.0 & 4.0 & 3.1 & 6.7 & 43.9 \\
\hline NG Army Aviation Support Facility & $P R$ & Army Guard & 2.7 & 5.0 & 10.0 & 10.0 & 0.0 & 8.0 & 3.1 & 4.5 & 43.3 \\
\hline SFC Minoru Kunieda USARC & $\mathrm{HI}$ & Army Reserve & 5.2 & 1.0 & 10.0 & 0.0 & 6.0 & 10.0 & 4.3 & 6.7 & 43.3 \\
\hline NG Watsonville & CA & Army Guard & 2.9 & 1.0 & 10.0 & 0.0 & 10.0 & 10.0 & 3.1 & 3.9 & 40.8 \\
\hline NG Eureka & CA & Army Guard & 10.0 & 1.0 & 10.0 & 0.0 & 7.8 & 4.0 & 3.1 & 3.9 & 39.7 \\
\hline NG Seaside & CA & Army Guard & 7.8 & 1.0 & 10.0 & 0.3 & 9.7 & 4.0 & 3.1 & 3.9 & 39.7 \\
\hline NG Toa Baja Readiness Center & PR & Army Guard & 3.4 & 3.0 & 10.0 & 4.9 & 0.0 & 10.0 & 3.1 & 4.5 & 38.9 \\
\hline Fort De Russy & $\mathrm{HI}$ & Army Active & 2.3 & 1.0 & 10.0 & 0.0 & 8.3 & 6.0 & 4.3 & 6.7 & 38.5 \\
\hline NG Bayamon Readiness Center & PR & Army Guard & 2.3 & 2.0 & 10.0 & 0.5 & 5.8 & 10.0 & 3.1 & 4.5 & 38.3 \\
\hline NG JF-HQS VI National Guard & $\mathrm{VI}$ & Army Guard & 2.2 & 1.0 & 10.0 & 0.0 & 7.0 & 6.0 & 3.1 & 8.1 & 37.3 \\
\hline NG Hato Rey Readiness Center & PR & Army Guard & 2.6 & 1.0 & 10.0 & 6.0 & 0.0 & 10.0 & 3.1 & 4.5 & 37.2 \\
\hline NG Regional Training Institute & $\mathrm{HI}$ & Army Guard & 4.8 & 4.0 & 10.0 & 6.1 & 0.3 & 2.0 & 3.1 & 6.7 & 37.0 \\
\hline NG Aguadilla Readiness Center & $\mathrm{PR}$ & Army Guard & 2.7 & 2.0 & 10.0 & 6.3 & 0.0 & 8.0 & 3.1 & 4.5 & 36.7 \\
\hline ITC Camp San Luis Obisbo & $\mathrm{CA}$ & Army Guard & 5.1 & 1.0 & 10.0 & 0.0 & 9.4 & 6.0 & 1.0 & 3.9 & 36.4 \\
\hline NG TS Kekaha WETS LTA & $\mathrm{HI}$ & Army Guard & 5.3 & 5.0 & 10.0 & 7.9 & 0.0 & 0.0 & 1.0 & 6.7 & 35.8 \\
\hline NG Kalaeloa & $\mathrm{HI}$ & Army Guard & 2.9 & 1.0 & 10.0 & 0.0 & 3.6 & 8.0 & 3.1 & 6.7 & 35.2 \\
\hline NG Fort Ruger & $\mathrm{HI}$ & Army Guard & 2.4 & 2.0 & 10.0 & 2.3 & 2.1 & 6.0 & 3.1 & 6.7 & 34.5 \\
\hline Ord Military Community & CA & Army Active & 7.9 & 1.0 & 10.0 & 0.0 & 1.9 & 8.0 & 1.0 & 3.9 & 33.7 \\
\hline Ramey USARC/Aquadilla & $P R$ & Army Reserve & 2.9 & 5.0 & 10.0 & 10.0 & 0.0 & 0.0 & 1.0 & 4.5 & 33.4 \\
\hline NG Vega Baja Readiness Center & $\mathrm{PR}$ & Army Guard & 3.8 & 1.0 & 10.0 & 0.0 & 0.4 & 10.0 & 3.1 & 4.5 & 32.8 \\
\hline NG Coos Bay Armory & OR & Army Guard & 10.0 & 1.0 & 10.0 & 0.1 & 3.4 & 4.0 & 1.0 & 2.2 & 31.7 \\
\hline NG Santa Cruz & $\mathrm{CA}$ & Army Guard & 3.3 & 2.0 & 10.0 & 1.7 & 5.2 & 2.0 & 3.1 & 3.9 & 31.2 \\
\hline
\end{tabular}




\subsubsection{Potential Air Force Wave Energy Sites at 5-Mile Radius}

Table 18 shows the preliminary list of Air Force bases with the highest potential based on the screening criteria applied for deployable projects using wave energy MHK technology.

Table 18. Air Force Sites with High Potential for Wave Energy MHK Projects at 5-Mile Radius

\begin{tabular}{|c|c|c|c|c|c|c|c|c|c|c|c|}
\hline Base Name & State & DOD Branch & $\begin{array}{c}\text { Mean WPD > } \\
4 \mathrm{~kW} / \mathrm{m} \text { to } \\
150 \mathrm{~m} \text { Depth }\end{array}$ & $\begin{array}{l}\text { Max WPD / } \\
\text { Mean WPD } \\
\text { Ratio }\end{array}$ & $\begin{array}{c}\text { Area with } \\
\text { WPD >4 } \\
\mathrm{kW} / \mathrm{m} 150 \mathrm{~m} \\
\text { Depth }\end{array}$ & $\begin{array}{c}\text { Distance to } \\
\text { Area with } \\
\text { WPD }>4 \mathrm{~kW} / \mathrm{m} \\
\text { to } 150 \mathrm{~m}\end{array}$ & $\begin{array}{l}\text { Distance } \\
\text { to Sub- } \\
\text { station }\end{array}$ & $\begin{array}{l}\text { Total } \\
\text { Exclu- } \\
\text { sions }\end{array}$ & $\begin{array}{l}\text { Electric } \\
\text { Load }\end{array}$ & $\begin{array}{l}\text { Cost of } \\
\text { Elec- } \\
\text { tricity }\end{array}$ & $\begin{array}{l}\text { Total } \\
\text { Points }\end{array}$ \\
\hline Name & ST & DOD & (pts) & (pts) & (pts) & (pts) & (pts) & (pts) & (pts) & (pts) & (pts) \\
\hline Vandenberg AFB & CA & AF Active & 10.0 & 5.0 & 10.0 & 10.0 & 10.0 & 0.0 & 10.0 & 3.9 & 58.9 \\
\hline Punamano AFS & $\mathrm{HI}$ & AF Active & 9.7 & 2.0 & 10.0 & 8.2 & 7.4 & 10.0 & 3.1 & 6.7 & 57.1 \\
\hline Pillar Point AFS & CA & AF Active & 7.7 & 3.0 & 10.0 & 10.0 & 7.5 & 10.0 & 3.1 & 3.9 & 55.2 \\
\hline Eareckson AS & AK & AF Active & 10.0 & 4.0 & 10.0 & 10.0 & 0.0 & 4.0 & 9.9 & 4.4 & 52.2 \\
\hline Punta Salinas Radar Site & PR & AF Guard & 2.9 & 5.0 & 10.0 & 10.0 & 8.5 & 10.0 & 1.0 & 4.5 & 51.9 \\
\hline Vandenberg Pt Arguello MTK03 & CA & AF Active & 10.0 & 4.0 & 10.0 & 10.0 & 2.7 & 6.0 & 3.1 & 3.9 & 49.7 \\
\hline Molokai Station & $\mathrm{HI}$ & AF Active & 6.4 & 5.0 & 10.0 & 10.0 & 0.0 & 10.0 & 1.0 & 6.7 & 49.1 \\
\hline Kaena Point Satellite Tracking Station & $\mathrm{HI}$ & AF Active & 6.0 & 5.0 & 10.0 & 10.0 & 0.0 & 10.0 & 1.0 & 6.7 & 48.7 \\
\hline Keaukaha Military Reservation & $\mathrm{HI}$ & AF Guard & 5.6 & 4.0 & 10.0 & 2.1 & 7.2 & 10.0 & 3.1 & 6.7 & 48.7 \\
\hline Bellows AFS & $\mathrm{HI}$ & AF Active & 5.3 & 5.0 & 10.0 & 10.0 & 6.3 & 0.0 & 4.3 & 6.7 & 47.6 \\
\hline Driftwood Bay Radio Relay Site & AK & AF Active & 7.4 & 2.0 & 10.0 & 10.0 & 0.0 & 10.0 & 3.1 & 4.4 & 46.9 \\
\hline Nikolski Radio Relay Site & AK & AF Active & 5.8 & 5.0 & 10.0 & 10.0 & 0.0 & 10.0 & 1.0 & 4.4 & 46.1 \\
\hline Kokee AFS & $\mathrm{HI}$ & AF Active & 7.9 & 2.0 & 10.0 & 4.7 & 0.0 & 10.0 & 4.3 & 6.7 & 45.6 \\
\hline Kahului Communications Station & $\mathrm{HI}$ & AF Guard & 3.3 & 5.0 & 10.0 & 10.0 & 0.0 & 8.0 & 1.0 & 6.7 & 44.0 \\
\hline Attu Research Site & AK & AF Active & 5.6 & 5.0 & 10.0 & 10.0 & 0.0 & 6.0 & 3.1 & 4.4 & 44.0 \\
\hline Mill Valley BCN & CA & AF Active & 3.8 & 4.0 & 10.0 & 8.1 & 1.1 & 10.0 & 3.1 & 3.9 & 44.0 \\
\hline Point Arena Communication Facility Ann & CA & AF Active & 9.7 & 1.0 & 10.0 & 0.0 & 5.6 & 10.0 & 3.1 & 3.9 & 43.3 \\
\hline Luis Munoz Marin IAP & PR & AF Guard & 2.7 & 5.0 & 10.0 & 10.0 & 10.0 & 0.0 & 1.0 & 4.5 & 43.2 \\
\hline Vandenberg Anderson Pk MTK02 & CA & AF Active & 6.5 & 5.0 & 10.0 & 6.2 & 0.0 & 8.0 & 3.1 & 3.9 & 42.7 \\
\hline Point Arena AFS & CA & AF Active & 9.3 & 1.0 & 10.0 & 0.0 & 2.6 & 10.0 & 1.0 & 3.9 & 37.8 \\
\hline Kaala AFS & $\mathrm{HI}$ & AF Active & 5.1 & 2.0 & 10.0 & 0.0 & 0.0 & 10.0 & 3.1 & 6.7 & 36.9 \\
\hline Isabela N00207-AB & PR & AF Active & 3.2 & 2.0 & 10.0 & 0.0 & 3.1 & 10.0 & 1.0 & 4.5 & 33.7 \\
\hline Francis S. Gabreski Airport & NY & AF Guard & 2.0 & 1.0 & 6.2 & 0.0 & 7.0 & 10.0 & 3.1 & 3.8 & 33.1 \\
\hline Cape Newenham Long Range Radar Site & AK & AF Active & 2.2 & 2.0 & 10.0 & 0.7 & 0.0 & 10.0 & 3.1 & 4.4 & 32.3 \\
\hline Punta Borinquen Radar Site & PR & AF Guard & 2.2 & 5.0 & 10.0 & 0.0 & 0.0 & 8.0 & 1.0 & 4.5 & 30.7 \\
\hline
\end{tabular}




\subsection{Down-Select from Screening Investigation}

The detailed screening data, combined with discussions with DOD RE Leads, contributed to narrowing down the sites with the best potential for future MHK projects. All of the sites presented above meet the technical requirements used in the screening process, indicating a potentially developable resource for each DOD branch. There were additional site factors that were not represented in the scoring scheme that came to bear in final site selection. It is expected that this will always be the case because each DOD facility is unique. Although the overall mission may be the same, considerable variance exists in how operations are carried out from facility to facility based on its specific mission(s) and a multitude of local factors.

\subsubsection{Army Site Visit Selection}

The Army RE Lead and NREL discussed the results of the screening and scoring in narrowing down the potential sites for a site visit. To enhance the discussions, NREL used the MHK Atlas. The results can be seen visually in Figure 18 for one of the Army sites.

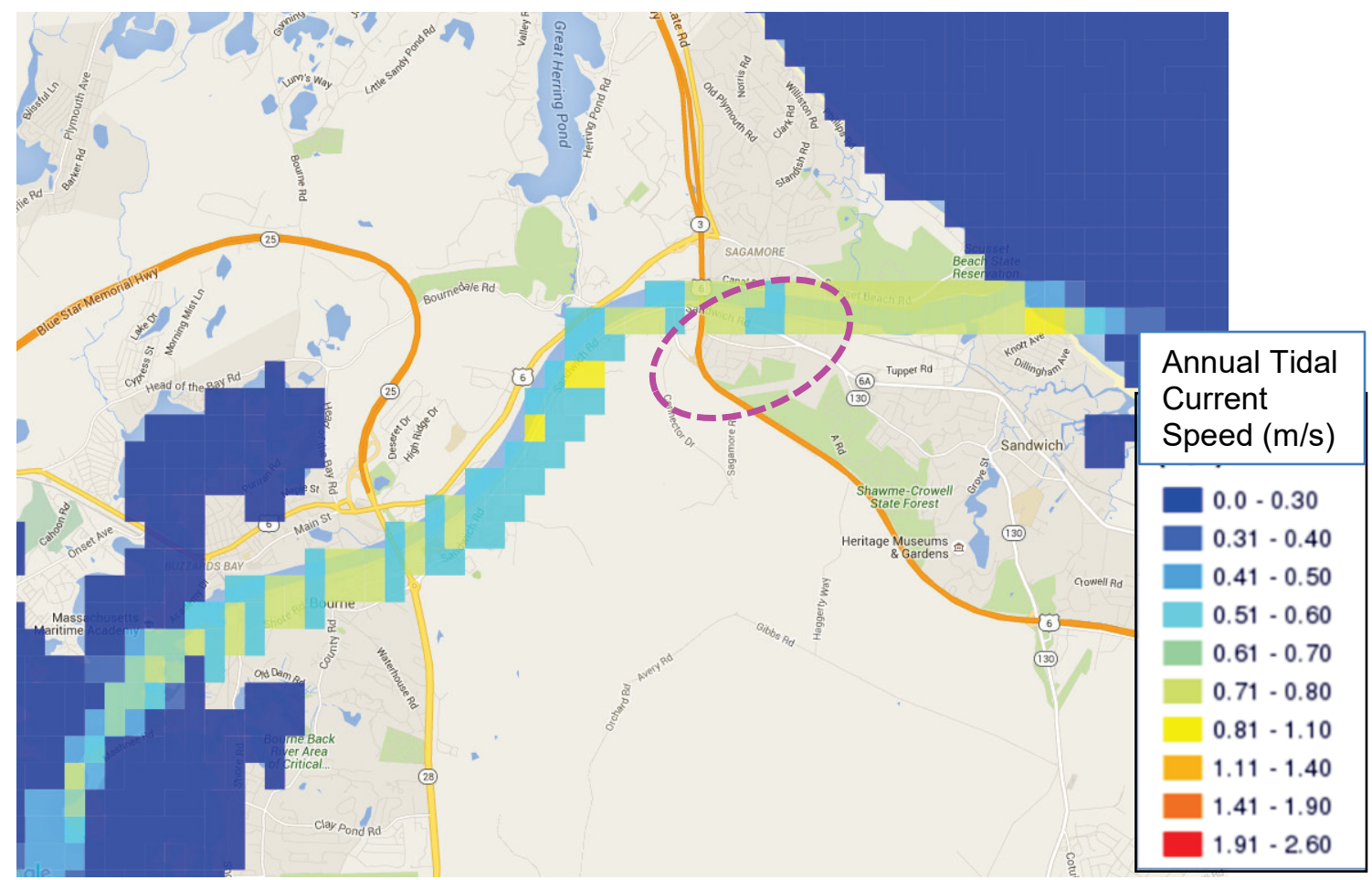

Figure 18. Annual tidal current speed in Cape Cod Canal near Camp Edwards

In consultation with the National Guard Bureau, the Army indicated that Camp Edwards, Bourne, MA, was a suitable site because it is one of the larger training areas and includes a significant number of buildings and full-time staff.

Many of the National Guard armories have smaller staff during the work week, although they often become very busy and heavily staffed one or two weekends per month during training exercises. The Army noted that the National Guard site at Camp Edwards was an exception-it was full during the week and periodically on drill weekends. 


\subsubsection{Coast Guard Site Visit Selection}

The Coast Guard RE Lead and NREL discussed the results of the screening and scoring in narrowing down the potential sites for a site visit. Investigative efforts beyond the initial project factor screening involved detailed discussions with USCG on 20 top sites. Two facilities emerged as having greater potential for tidal energy suitable for further investigation:

- USCG Station at Portsmouth Harbor, NH

- U.S. Coast Guard Training Center Cape May (TRACEN Cape May), NJ.

To enhance the discussions, NREL used the MHK Atlas. The results for TRACEN Cape May can be seen visually in Figure 19.

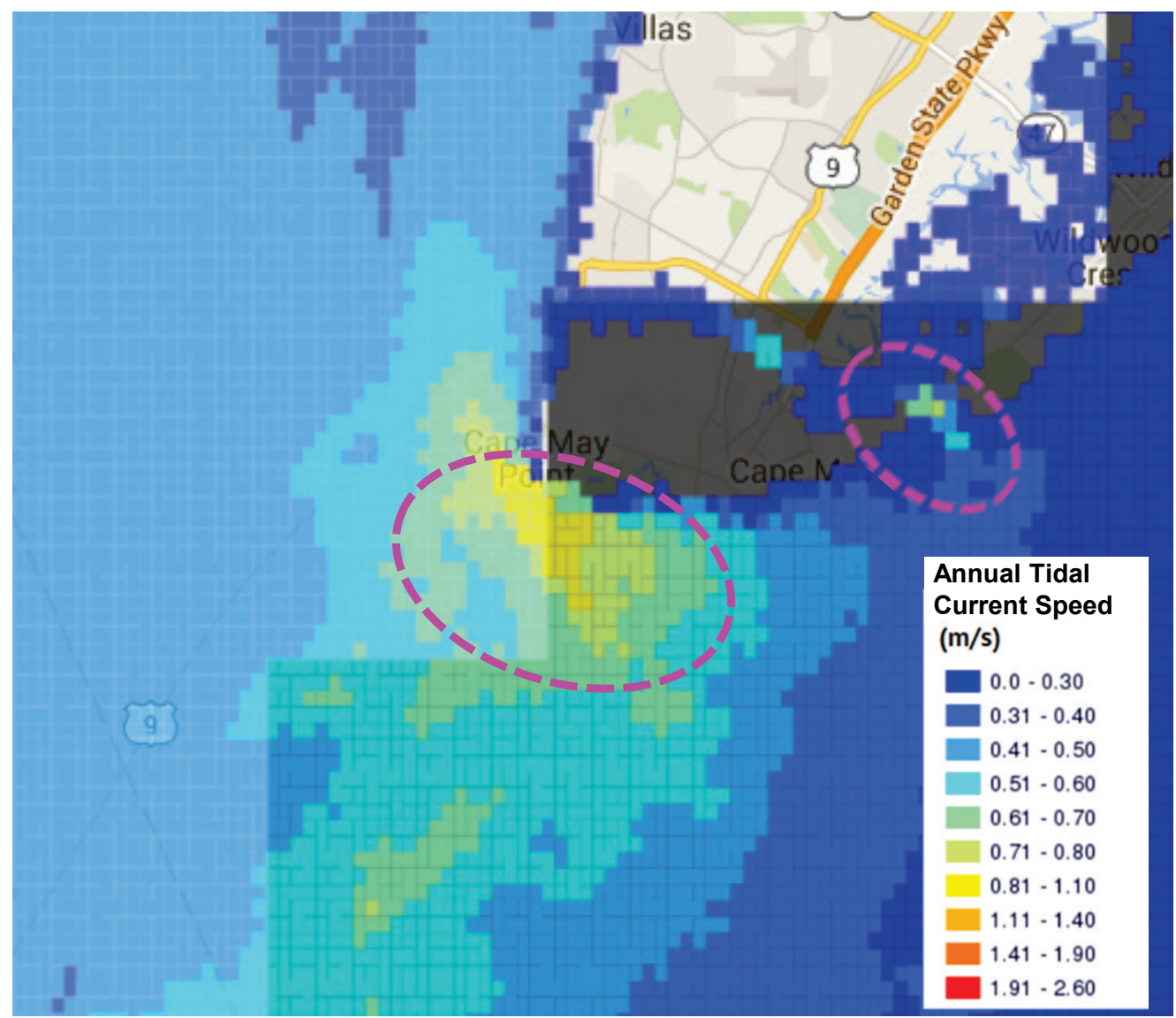

Figure 19. Tidal current speed in the Delaware Bay and Cape May Inlet near Cape May

Other information provided additional impetus, beyond the scoring criteria, in identifying positive potential project factors. This information included site-specific electrical utility infrastructure condition, strategic base master planning to add supplementary energy sources, potential active mission variability, broader Coast Guard financial stewardship goals, and ongoing renewable energy projects for each of the screened sites. 
Additionally, there were some unique attributes associated with TRACEN Cape May that included:

- The strategic location, and the associated vulnerability of TRACEN Cape May within the series of USCG facilities along the East Coast and its potential to increase the resiliency and security of USCG operations across the mid-Atlantic region;

- Enhancing continuity of operations for tenant commands co-located on the base, tenant federal agencies co-located on the Base (Veterans Affairs), and the substantial benefit to dependent families in adjacent Coast Guard owned housing;

- The geographic size of the tidal resource in the vicinity of Cape May and its unique characteristics being different from most of the other tidal resources available at Coast Guard bases;

- The potential of using the available tidal resources to establish a tidal technology testing facility; and

- The number and percentage of Coast Guard personnel who come through TRACEN Cape May for training. Exposure to MHK technology will be beneficial to the USCG.

USCG conducted targeted and regional vessel traffic studies to further delineate the potential for both future MHK development and potential suitability for developing a research and testing center. These studies pointed to several advantages for the potential tidal energy site near TRACEN Cape May off the southern tip of Cape May. Several annotated graphics from the study visually highlight positive aspects of siting a tidal testing in an area of accelerated tidal flow identified by the Georgia Tech analysis.

\subsection{Cape May and Delaware Bay Vessel Traffic Study}

The following text and graphics (Figures 20 and 21) are excerpts from the broad-based vessel traffic study with the graphics having labels added to enhance clarity.

Assessments are largely based on historical shipping data from 2013 for fishing vessels, pleasure craft and sailing vessels, tugs and towing vessels, and tankers; however, other factors such as open-source information and historical trends were also taken into consideration in this assessment.

The datasets for the accompanying graphics were drawn from Automatic Identification Systems (AIS) reports. AIS is a navigation safety device that transmits and monitors the location and characteristics of vessels in U.S. and international waters in real-time. This dataset represents the density of all vessel traffic identified as Fishing Vessels, Pleasure Craft and Sailing Vessels, Tugs and Towing Vessels, and Tankers in 2013 for Cape May, NJ, and Portsmouth, NH. These data are derived from vessels with AIS transponders in 100-meter grid cells. The dataset is interpreted using a high to low density scale and does not represent actual vessel counts. The BOEM and NOAA have worked jointly to repurpose and make available some of the most important records from the U.S. Coast Guard's national network website of AIS receivers. 
Key findings for Cape May include:

- CGI assesses that the area directly southwest of Cape May Point likely experiences negligible amounts of marine traffic whereas much of the waters directly to the east and west of Cape May experience moderate levels of routine vessel traffic, with shipping lanes further offshore experiencing higher volumes of vessel traffic on a regular basis. We have high confidence in this assessment based on AIS data.

- The area southwest of Cape May Point is generally devoid of fishing vessel traffic. Most fishing vessels dock in Cape May Harbor and then depart the area.

- Pleasure craft and sailing vessels do congregate near Cape May Point; however, they are centered 2 to 5 miles directly south of that point. Although many large pleasure craft and sailing vessels do use AIS, many small vessels do not. It is likely that there are small vessels in the area surrounding Cape May that are not accounted for in the accompanying graphics. It is also important to note that in the summer months Cape May is a popular tourist destination and there may be large number of small pleasure vessels, including jet skis, that operate around Cape May, including near the beach.

- The area southwest of Cape May Point is generally devoid of tug and towing vessels; however, these vessels regularly transit close to shore as a shortcut between normal shipping lanes.

- Tanker traffic in the depicted area around Cape May is negligible; therefore, a graphic depicting tanker traffic was not included. However, there are very active shipping lanes a short distance beyond the depicted area with very high volumes of large tanker vessels. 


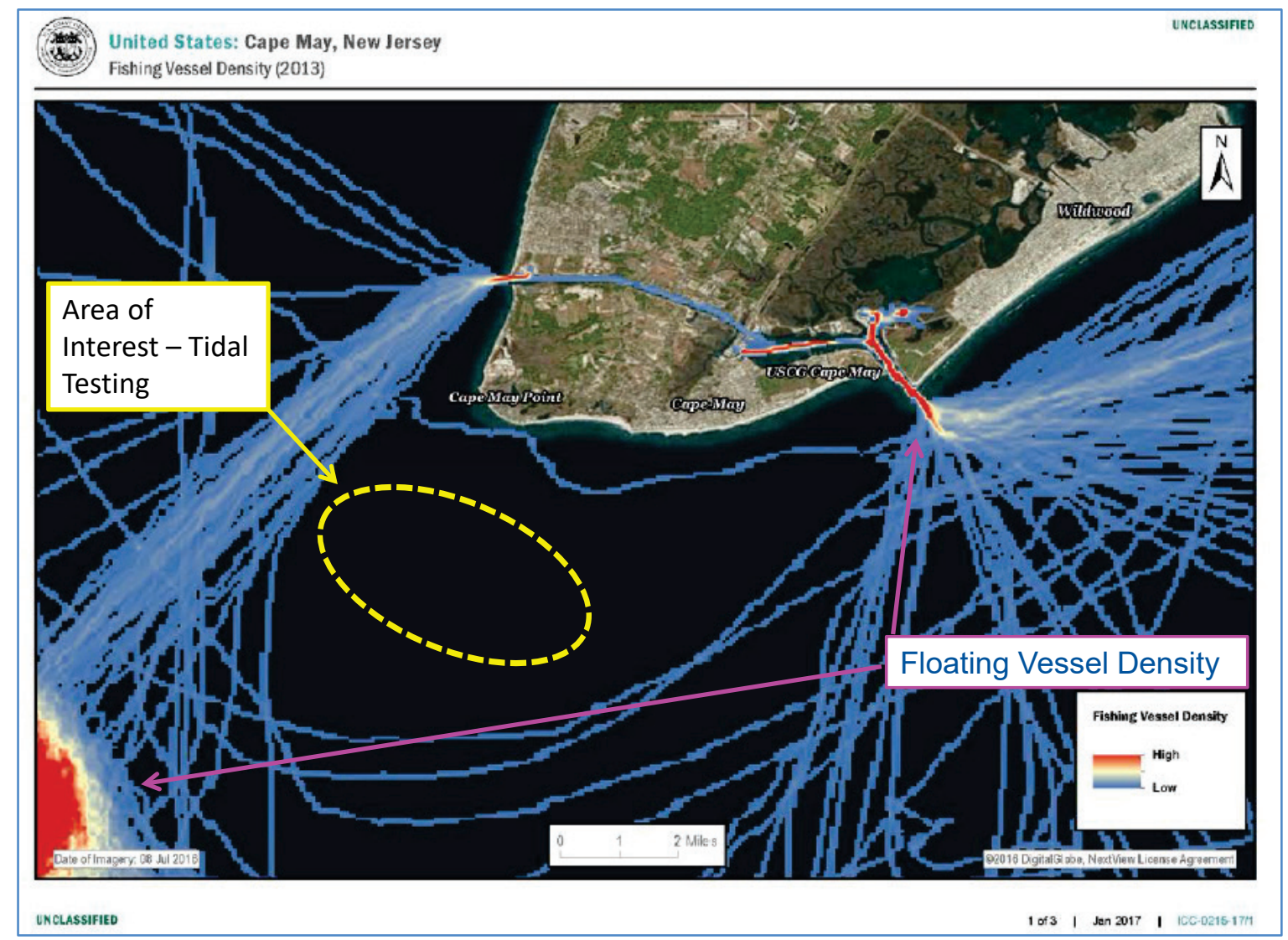

Figure 20. Floating Vessel Traffic Study depicting traffic density likely in the vicinity of a potential tidal turbine test site 


\section{Site Visit Summaries}

Findings of individual site investigations are detailed in the sections that follow.

\subsection{U.S. Coast Guard Training Center Cape May Site Visit Overview}

The TRACEN Cape May facility is located at Sewell Point, about 2.5 miles $(4 \mathrm{~km})$ in length entirely within the City of Cape May, along the Atlantic Ocean coast of eastern New Jersey (Figure 21). It is the southernmost barrier island in New Jersey separating Delaware Bay from the Atlantic Ocean.

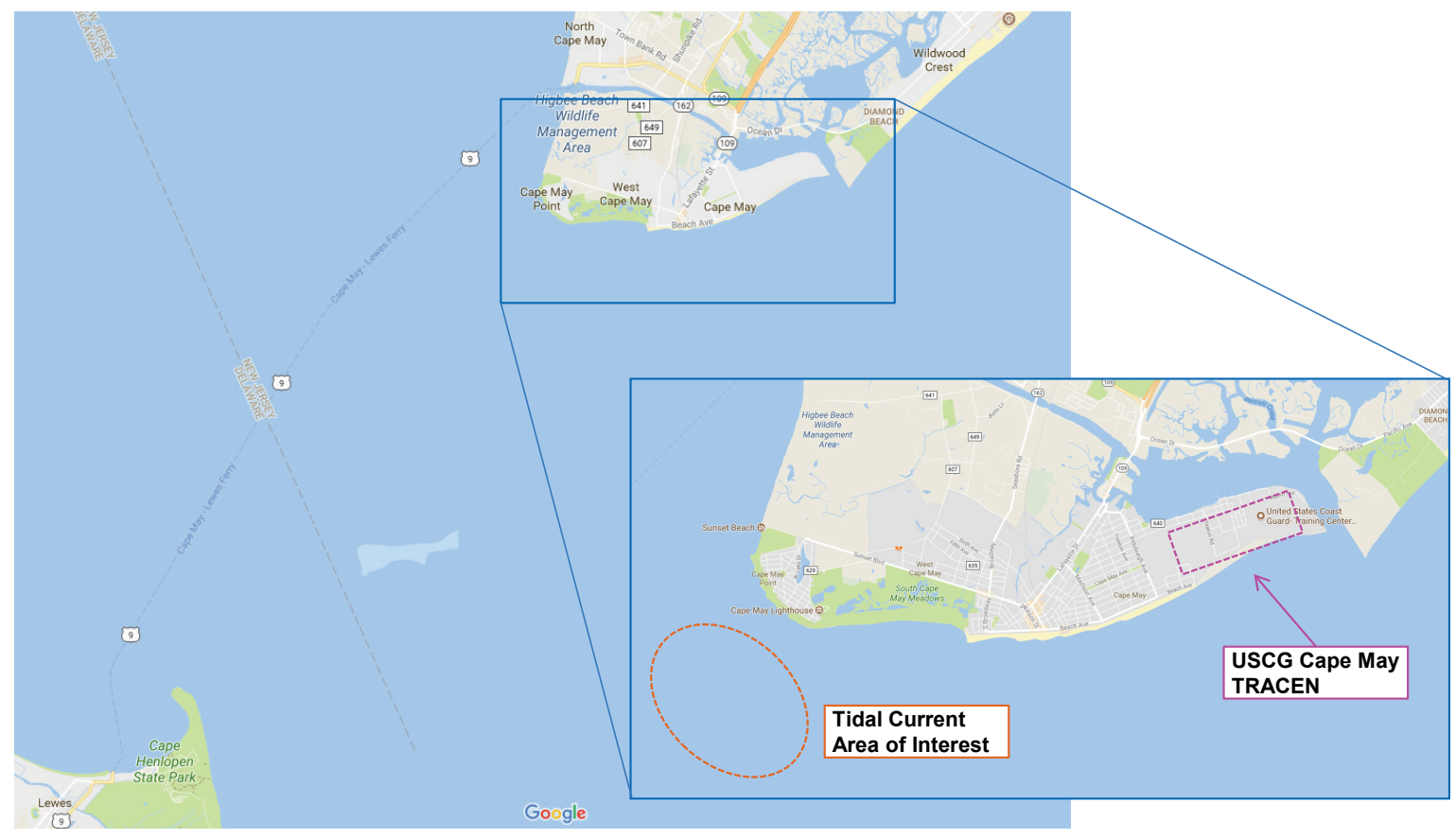

Figure 21. Regional map showing southern New Jersey, Cape May, and Delaware Bay

The visit to the U.S. Coast Guard Training Center Cape May (TRACEN Cape May) site took place on March 23, 2017. Representatives from Coast Guard Headquarters Office of Energy Management and Office of Civil Engineering, DOE, and NREL met with Facilities, Site, Engineering, Utility, and Energy managers.

During the site visit, Coast Guard HQ and NREL briefly presented an overview of the factors that contributed to Cape May being selected for the site visit and some of the work that had been completed:

- MHK study parameters for the Coast Guard

- The tidal resource in the vicinity of Cape May and its unique characteristics

- The current state of the tidal current technology and potential future cost and technology development scenarios.

The group engaged in active discussion of the potential benefits and challenges of siting a tidal testing facility off the southern tip of Cape May. The USCG Lead cited several energy security benefits and strategic operations advantages that this site would have. It would provide the Coast Guard with one more East Coast resiliency capability that would enhance existing facilities at Charleston, SC; Elizabeth City, NC; and Yorktown, VA. 


\subsubsection{Cape May Electrical Infrastructure Investigation}

The Electrical Engineering Department at TRACENCM provided a set of electrical infrastructure drawings and diagrams that contributed to a better understanding of the existing infrastructure and how different-sized MHK systems could be integrated into the existing system.

\subsubsection{General Electrical Design Concept}

The general electrical design concept was put together integrating major systems and subsystems that will be required to bring electrical power from the potential testing station to the distribution grid at Cape May. The following sections outline these components.

\subsubsection{Power Conversion}

The electrical power conversion in this type of generation is very similar to the generating system of wind power generation. It consists of major components: a rectifier (variable AC-to-DC converter) and an inverter (DC-to-AC 60-Hz converter). Depending on the generator type, the rectifier can either be passive or active.

The major conversion processes are as follows:

- Hydrokinetic energy is converted into variable AC power;

- Variable AC (three-phase) voltage is converted (rectified) into variable DC voltage;

- Variable DC output voltage of the diode bridge is connected to a DC-DC converter, to provide constant DC;

- Constant DC voltage is converted into three-phase $\mathrm{AC}$ at $60 \mathrm{~Hz}$; and

- $\mathrm{AC}$ voltage is transformed for interconnection.

The following single-line diagram (Figure 22) describes this system.

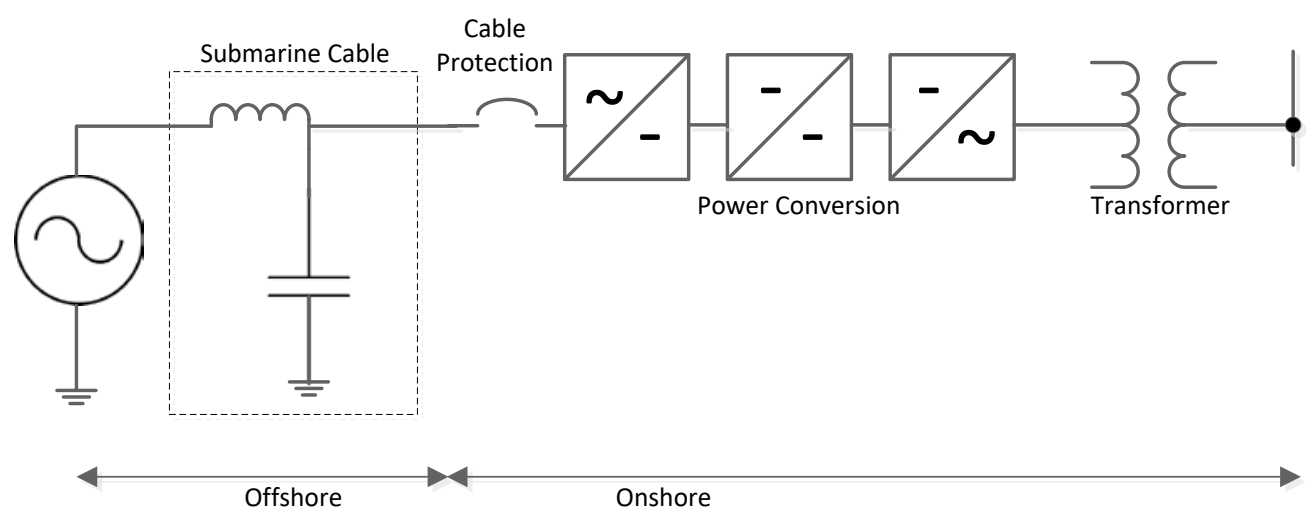

Figure 22. Single-line diagram

\subsubsection{Transmission}

The power transmission system from the generator to the substation transformer of a tidal or river generator is illustrated in Figure 23. 


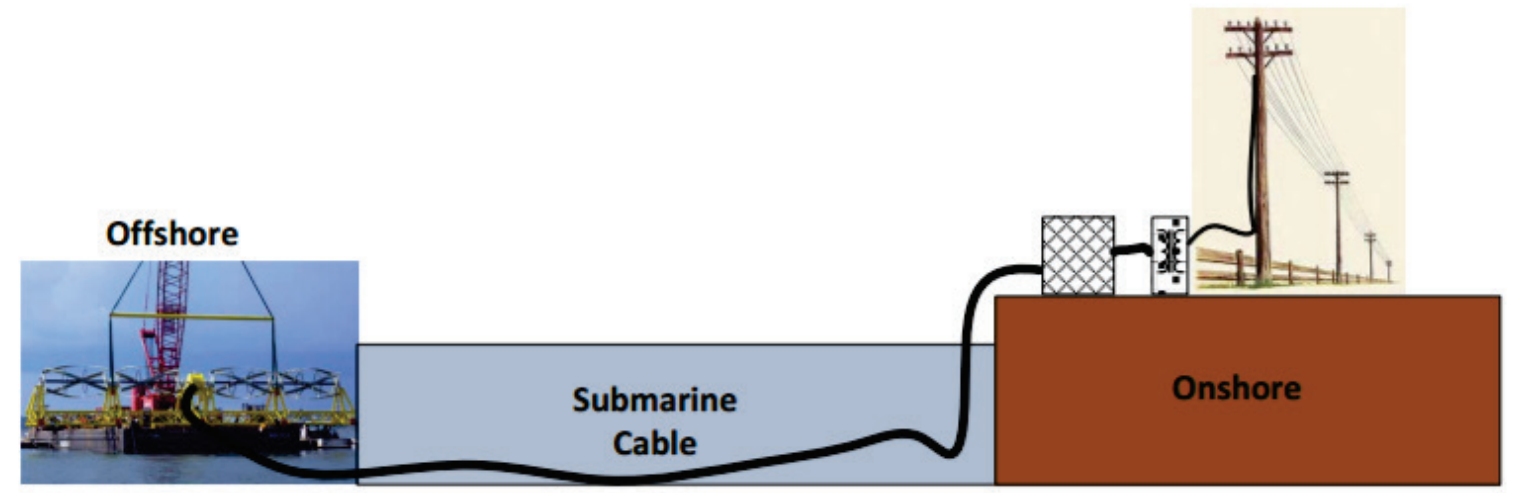

Figure 23. Typical electrical power transmission system from generator to substation transformer

\subsubsection{Balance of Plant}

As shown in the single-line diagram (Figure 22) and the previous illustration (Figure 23), electrical transmission operates in two main environments - offshore and onshore. Furthermore, for purposes of this concept, the balance of electrical plant consists of the following categories of equipment: marine cable, protection systems, power conversion systems, switchgear, and transformer.

Electrical infrastructure costs are influenced by the type of cables and the distance from shore. Estimated cable runs will be considered in the following sections, with respect to each of the areas of interest.

\subsubsection{Southern Tip of Cape May Interconnection}

The TRACEN Site Plan suggests the following location (Figure 24) for the Southern Tip interconnection. The area south of Building 293 provides ample space and vehicular access (Fraser Avenue) for construction and maintenance.

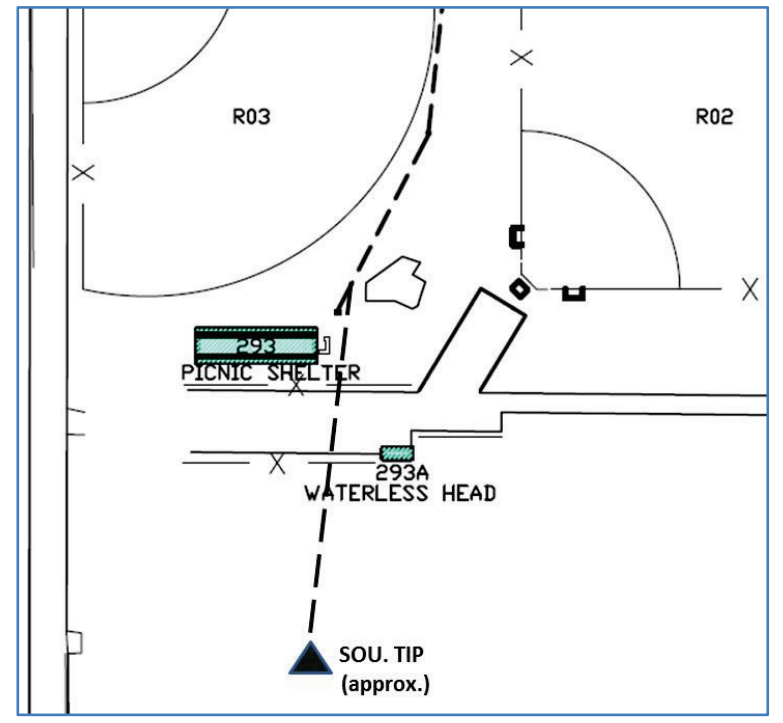

Figure 24. Proposed location for Southern Tip interconnection

Figure 25 provides a general schematic of the interconnection, with the dotted-oval enclosing the revision. 


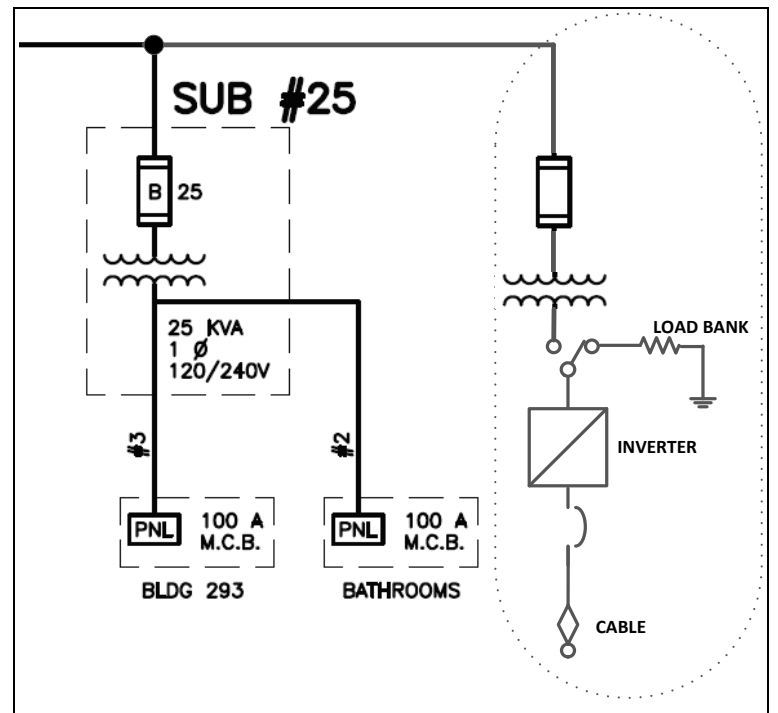

Figure 25. Electrical schematic for Southern Tip interconnection 


\subsubsection{Cape May Inlet}

The TRACENCM Site Plan suggests the following location (Figure 26) for the Cape May Inlet interconnection. The area west of Property 202 provides ample space and vehicular access (Arcus Road) for construction and maintenance. The dredging disposal area (outlined in blue, Figure 26) impedes a more direct interconnection, possibly near Buildings 302 and 194, but this should be evaluated.

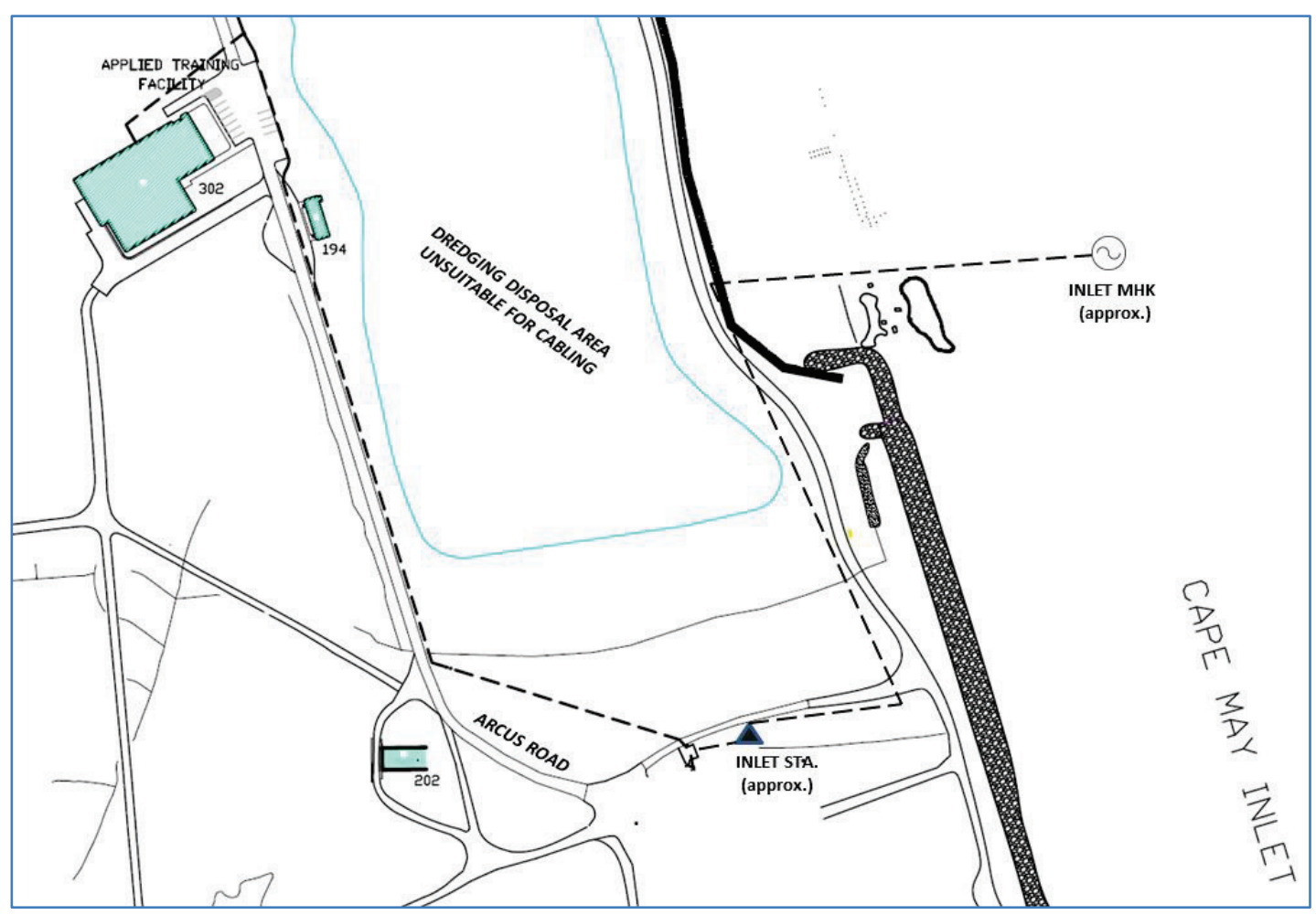

Figure 26. Proposed location for Cape May interconnection 
Figure 27 provides a general schematic of the interconnection, with the dotted-oval enclosing the revision.

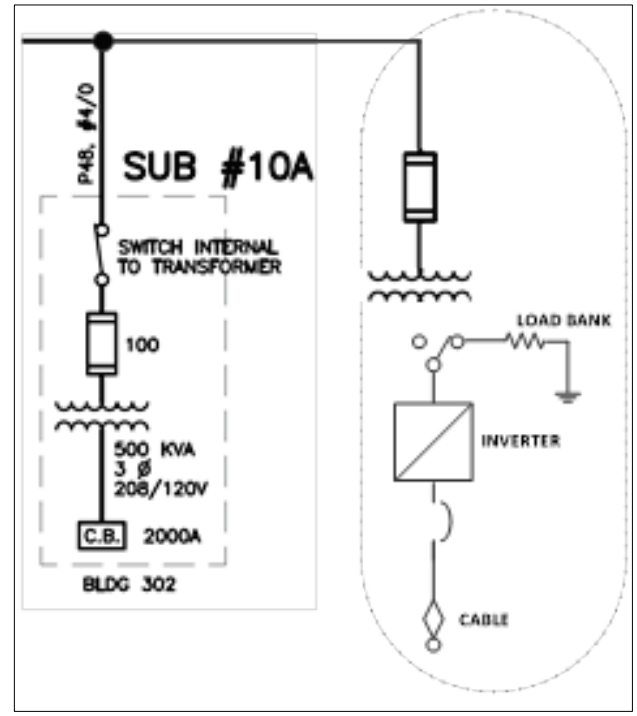

Figure 27. Schematic for Cape May Inlet interconnection

\subsubsection{Other Considerations - Licensing}

The Federal Energy Regulatory Commission (FERC) has governance authority over the licensing of projects that generate electricity from waves or directly from the flow of water in ocean currents, tides, or inland waterways. Federal agencies with congressional authorization are the exception. Otherwise, a FERC license is required to operate a hydrokinetic project on the Outer Continental Shelf (OCS).

In 2013, the USCG and FERC signed an agreement to coordinate development of MHK projects. The purpose of the Memorandum of Understanding (MOU $)^{26}$ is to advance interagency cooperation in protecting navigation safety, maritime security, and environmental resources when considering license proposals for MHK energy development. Specifically, the MOU sets forth the ability of the agencies to:

- Establish a joint timetable,

- Identify critical issues early,

- Acquire and share information efficiently, and

- Collaborate on analysis.

\subsubsection{Utility Interconnection}

Cape May station is served electric power by Atlantic City Electric (ACE), a subsidiary of the Exelon Corporation and has an interest in the interconnection of generation to safeguard electric reliability and public safety.

\footnotetext{
26 "Memorandum of Understanding between the Federal Energy Regulatory Commission and the United States Coast Guard for Hydrokinetic Projects.” Effective March 6, 2013. Accessed at https://www.ferc.gov/legal $/ \mathrm{mou} / \mathrm{mou}-\mathrm{uscg}-03-$ 2013.pdf
} 


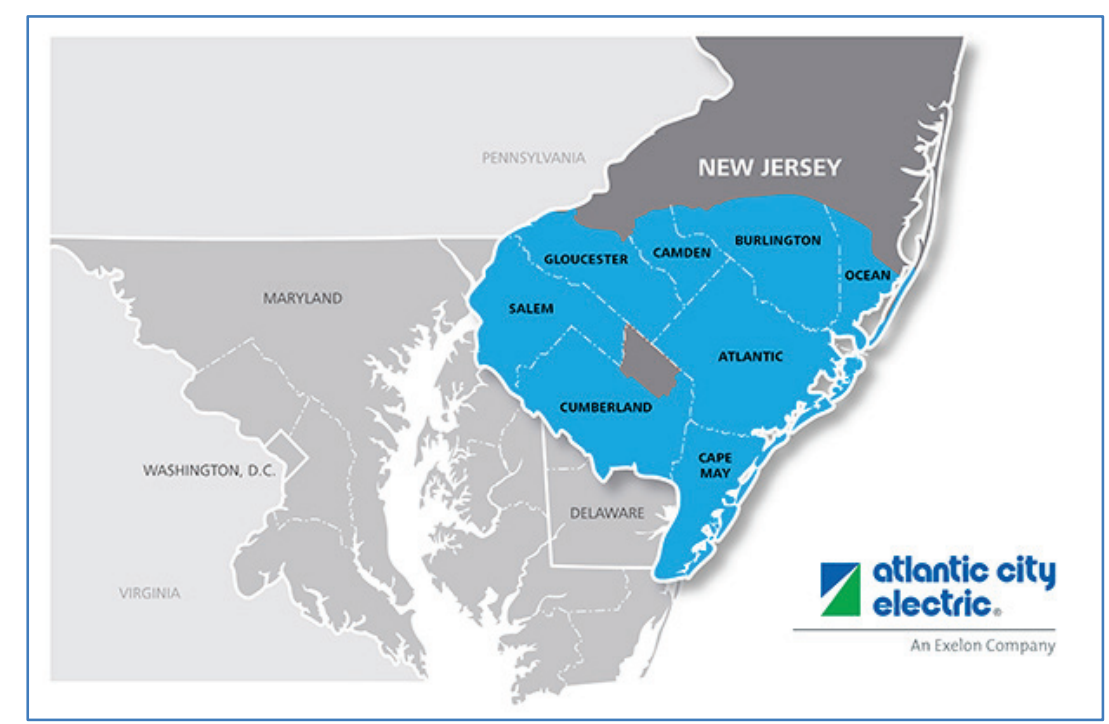

Figure 28. Service area map ${ }^{27}$

The State of New Jersey Board of Public Utilities is the authority for the New Jersey Administrative Code (N.J.A.C.) 14:8, which defines the interconnection application processes that ACE follows. Small-generator technologies that qualify for interconnection in New Jersey include solar (photovoltaic or "PV"), wind, fuel cells, geothermal, wave or tidal action, methane gas, or biomass. Accordingly, generating systems can be sized to meet up to $100 \%$ of an applicant's energy needs over an historical 12-month period. ${ }^{28}$

In some regions, ACE may not have an open circuit, making additional interconnections unavailable. The map in Figure 29 shows general areas where circuits are restricted at the time of this report. Considerations that apply to interconnection of distributed energy resources are complex and constantly evolving. Consequently, the accuracy of the information found on this map cannot be guaranteed and is presented for information-purposes only.

\footnotetext{
${ }^{27}$ Publicly available service area map, accessed at http://www.atlanticcityelectric.com/connect-with-us/doing-businesswith-us/builders-and-inspectors/resources/service-area-map/

${ }^{28}$ New Jersey Administrative Code (N.J.A.C.): § 14:8-4.1
} 


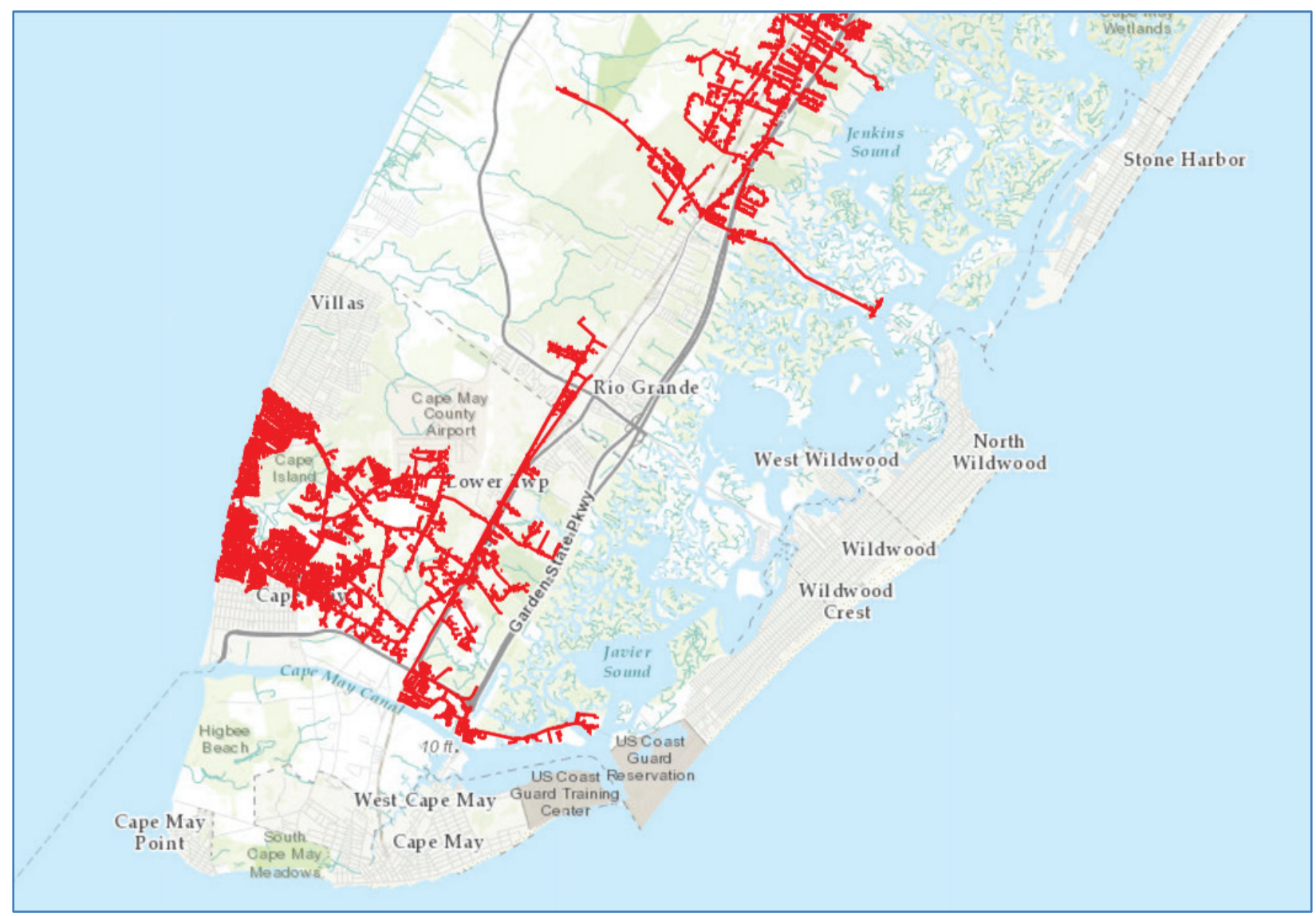

Figure 29. Restricted circuit map: Maximum system size of $50 \mathbf{k W}^{29}$

\subsection{US Army National Guard Camp Edwards}

\section{Site Visit Overview}

The visit to the U.S. Army National Guard Camp Edwards (Camp Edwards) site (Figure 30) took place on May 18, 2017. NREL met with the Energy Manager and the Master Planner for Massachusetts Army National Guard.

29 "Restricted Circuit Map" accessed through link provided at http://www.atlanticcityelectric.com/Restricted-CircuitMap.aspx 


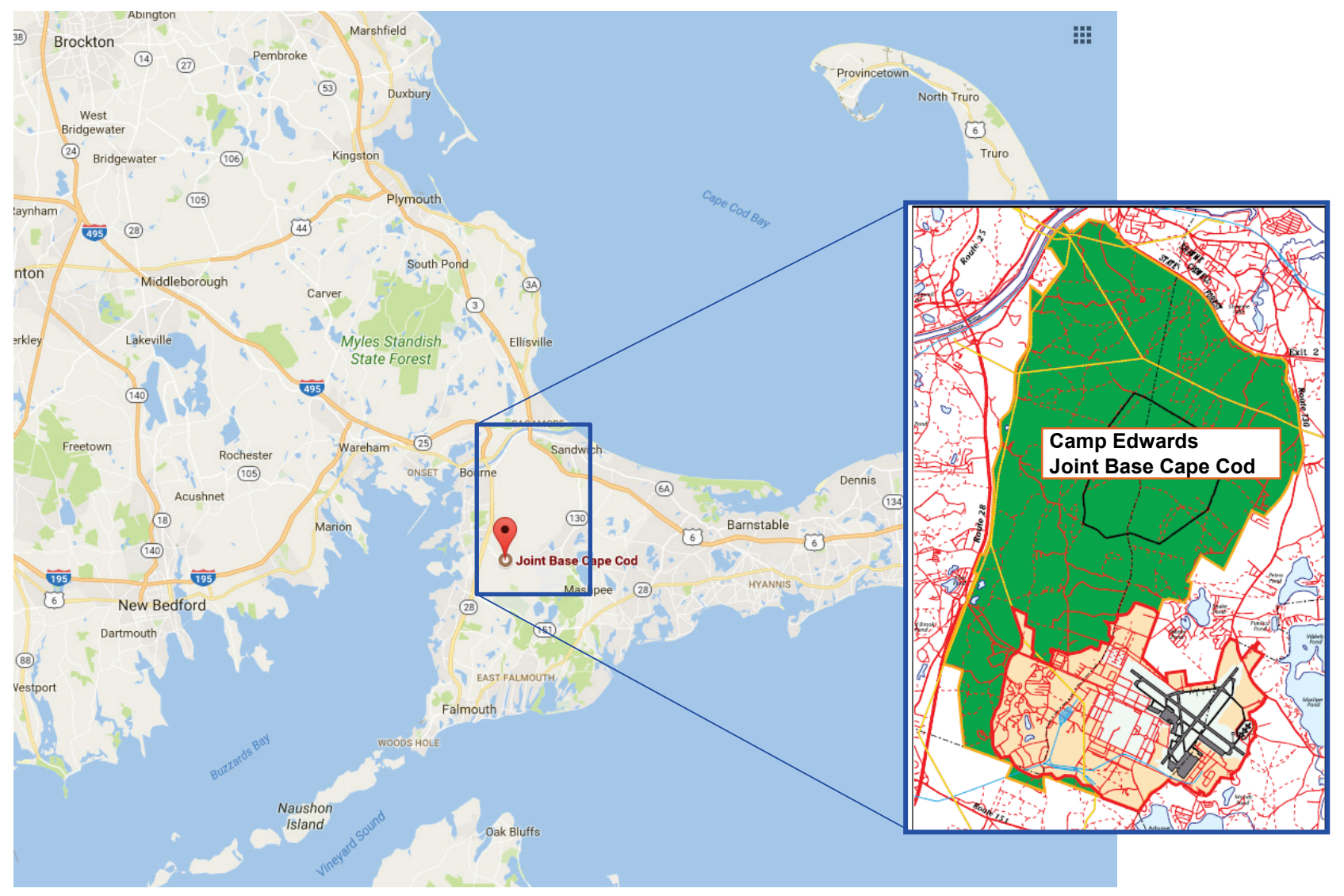

Figure 30. Overview map of Cape Cod, Joint Base Cape Cod and the surrounding waterways

During the site visit, NREL briefly presented an overview of the factors that contributed to Camp Edwards being selected for the site visit and some of the work that had been completed:

- MHK study parameters for the Army

- The tidal resource in the vicinity of Camp Edwards along the Cape Cod Canal and its unique characteristics

- The current state of the tidal current technology and potential future cost and technology development scenarios.

The group engaged in active discussion of the potential benefits and challenges of siting a tidal energy project in the Cape Cod Canal and bringing the power to the substation at the north end of the base. The Master Planner expressed interest, as the LCOE of tidal energy comes down over time, to include potential MHK sites in the 5- and 10-year site development plans. With improved reliability and decreased costs, the potential for increasing the energy resilience of Camp Edwards and Joint Base Cape Cod with this technology will become more apparent. Engaging with other Cape Cod Canal stakeholders would be a logical course of action at some point in the future as the LCOE of tidal turbines become more cost competitive.

\subsubsection{Camp Edwards Electrical Infrastructure Investigation}

The Energy Manager at Camp Edwards provided a set of electrical infrastructure drawings and diagrams from the Electrical Engineering Department that contributed to a better understanding of the existing infrastructure and how different-sized MHK systems could be integrated into the existing system. 


\subsubsection{General Electrical Design Concept}

The general electrical design concept was put together integrating major systems and subsystems that will be required to bring electrical power from the potential testing station to the distribution grid at Camp Edwards. The following sections outline these components.

\subsubsection{Power Conversion}

The electrical power conversion in this type of generation is very similar to the generating system of wind power generation. It consists of major components: a rectifier (variable AC-to-DC converter) and an inverter (DC-to-AC 60-Hz converter). Depending on the generator type, the rectifier can be either passive or active.

The major conversion processes are as follows:

- Hydrokinetic energy is converted into variable AC power;

- Variable AC (three-phase) voltage is converted (rectified) into variable DC voltage;

- Variable DC output voltage of the diode bridge is connected to a DC-DC converter, to provide constant DC;

- Constant DC voltage is converted into three-phase $\mathrm{AC}$ at $60 \mathrm{~Hz}$; and

- AC voltage is transformed for interconnection or transmission.

The following single-line diagram describes this system (Figure 31).

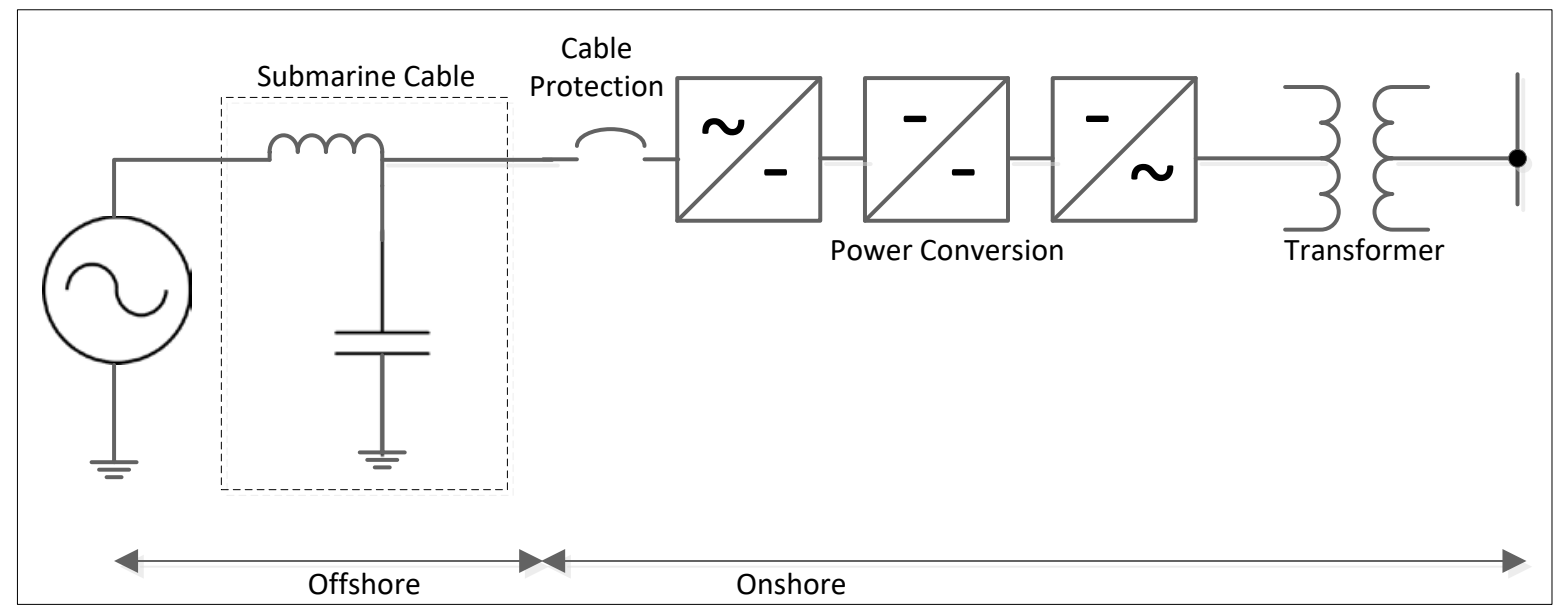

Figure 31. Single-line diagram for Camp Edwards

\subsubsection{Transmission}

The power transmission system from the generator to the shore-side transformer of a tidal or river generator is illustrated in Figure 32. 


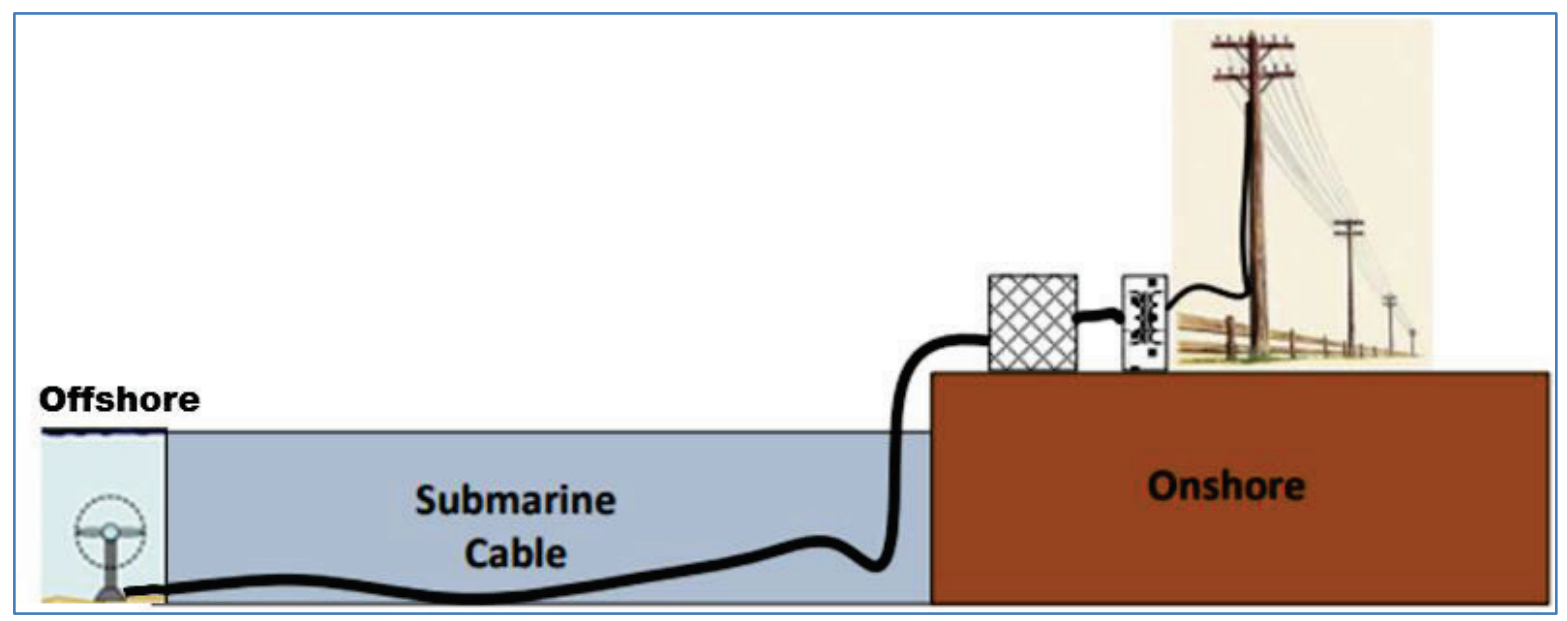

Figure 32. Typical electrical power transmission system from generator to substation transformer

The underwater cable connection from the MHK generator installed on the floor of the Cape Cod Canal to shore-side is illustrated in Figure 33. Using Google Earth, the estimated length of the cable is about 2,000 meters.

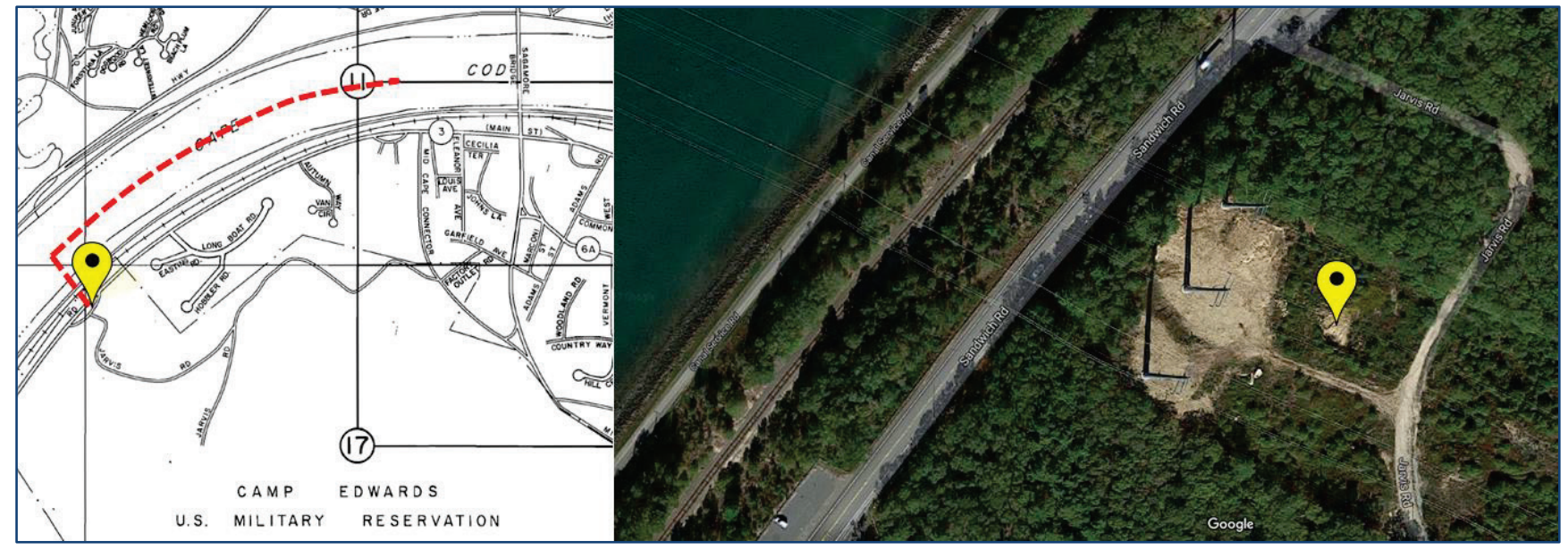

Figure 33. Marine-land cabling (concept) ${ }^{30}$

\subsubsection{Feeder Connection - Onshore to Camp Edwards}

The electrical transmission and distribution circuits crisscrossing the Camp Edwards boundaries are illustrated in Figure 34. Based on analysis and review of available information, two critical substations are noted in the figure: NSTAR SUB $(115 \mathrm{kV} / 345 \mathrm{kV})$ and the Otis primary delivery point, which is estimated to be at 15,000 VAC $(15 \mathrm{kV})$. Because Camp Edwards does not take service at the NSTAR substation $(115 \mathrm{kV} / 345 \mathrm{kV})$, it is recommended that a new distribution service (dashed line in Figure 34), at delivery voltage, be built to the Otis primary delivery point substation.

\footnotetext{
${ }^{30}$ Property Map, Town of Bourne Massachusetts, Sheet Index 1, Revised 1995.
} 


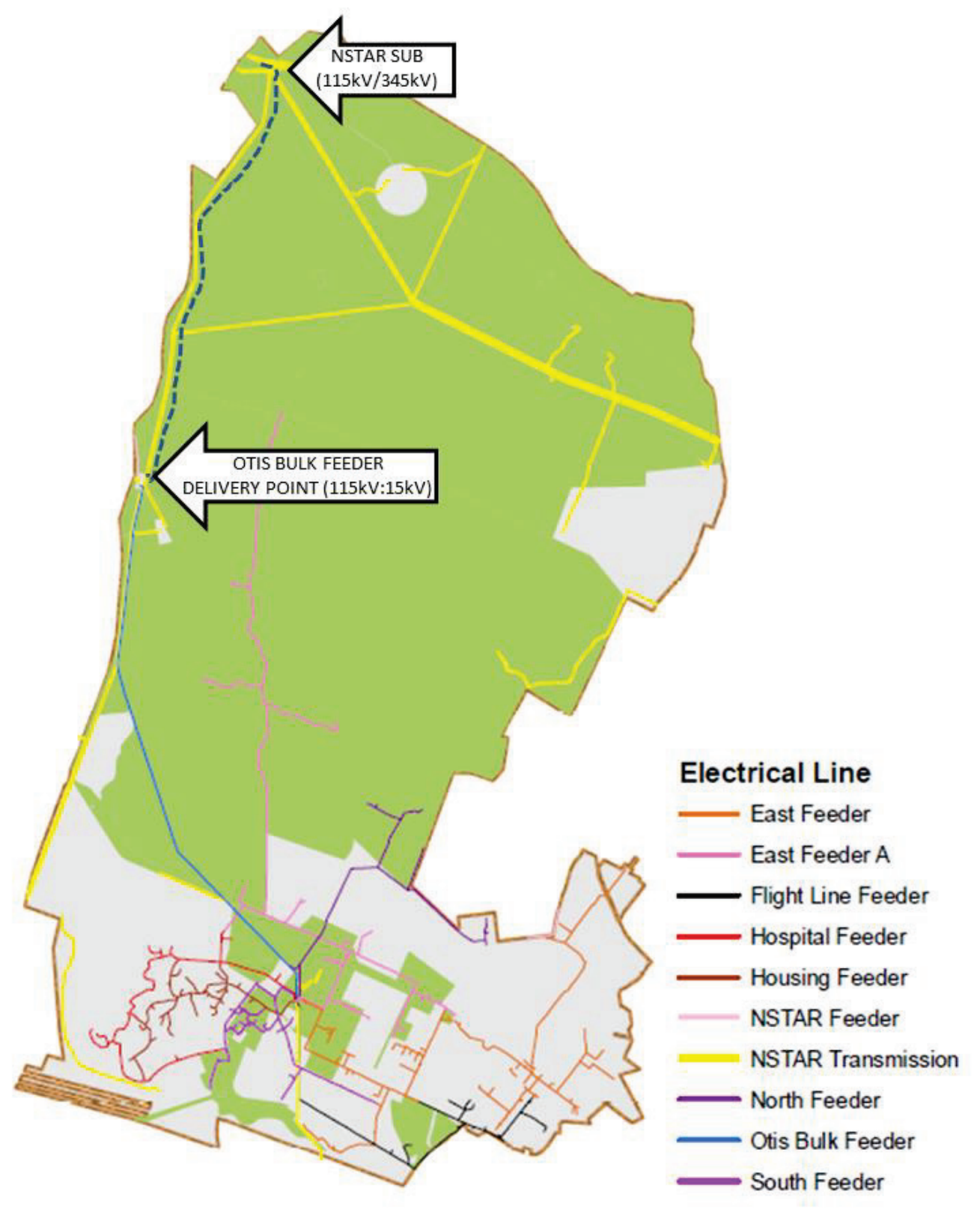

Figure 34. Electrical lines on MAARNG parcel ${ }^{31}$

Conceptually, Eversource (NSTAR) would develop, design, and construct this distribution feeder connection (Figure 35) - either as an under-build to the existing 115-kV line serving Otis substation $(15 \mathrm{kV} / 115 \mathrm{kV})$ or as an overhead distribution circuit sharing the existing transmission line right-ofway (ROW). ${ }^{32}$ The distance from the NSTAR substation to the Otis-delivery-point substation is about 4 miles.

\footnotetext{
31 "CAMP EDWARDS - 25175, Lines on MAARNG Parcel," 6 July 2011. (MAARNG: Massachusetts Army National Guard).

32 The Otis Bulk Feeder shares the 115-kV ROW for about 2,400 meters (1.5 miles) south (before traveling southsoutheast to the central Camp Edwards campus). Sharing the existing ROW seems technically feasible on a new northern circuit.
} 

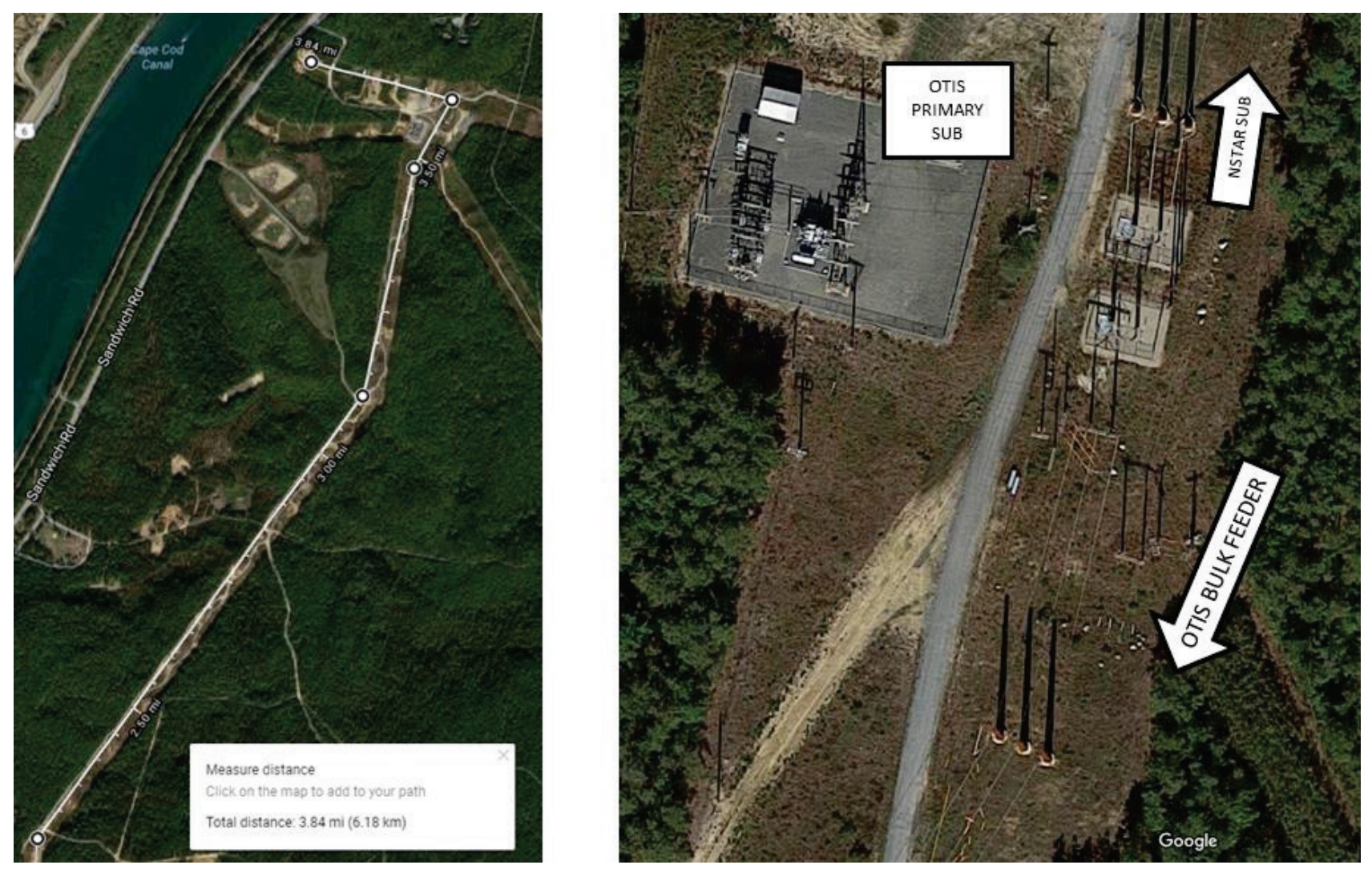

Figure 35. Proposed new circuit connecting "Area of Interest" to Camp Delivery-point

Consideration for the electrical connection at the Otis-delivery-point substation is also required. Generally, the requirements for this connection will be specified by the utility (Eversource/NSTAR). This connection will most likely be considered the point of common coupling (PCC) with respect to Massachusetts small-generator interconnection requirements (discussed later in this report, "Utility Interconnection").

\subsubsection{Balance of Plant}

As shown in the single-line diagram (Figure 31) and the illustration (Figure 32), electrical transmission operates in two main environments - offshore and onshore. Furthermore, for purposes of this concept, the balance of electrical plant consists of the following categories of equipment: marine cable, protection systems, power conversion systems, switchgear, and transformer. Electrical infrastructure costs are influenced by the type of cables and the distance from canal bank. Estimated cable runs will be considered in the following sections, with respect to the area of interest.

\subsubsection{Utility Interconnection}

Camp Edwards is served electric power by Eversource Energy (formerly known as Northeast Utilities, NU) ${ }^{33}$ headquartered in Boston, MA, and Hartford, CT (Figure 36). Eversource Energy (ES) offers retail electricity and natural gas service to more than 3.6 million customers in Connecticut, Massachusetts and New Hampshire. The ES asset base includes more than 4,270 circuit-miles of electric transmission lines, and 72,000 pole-miles of distribution lines in New England.

\footnotetext{
${ }^{33}$ Boston-based NSTAR merged with Northeast Utilities (NU) in 2012. Many documents and site plans still refer to the power company as NSTAR. In 2015, NU and all its subsidiaries rebranded themselves as "Eversource Energy."
} 


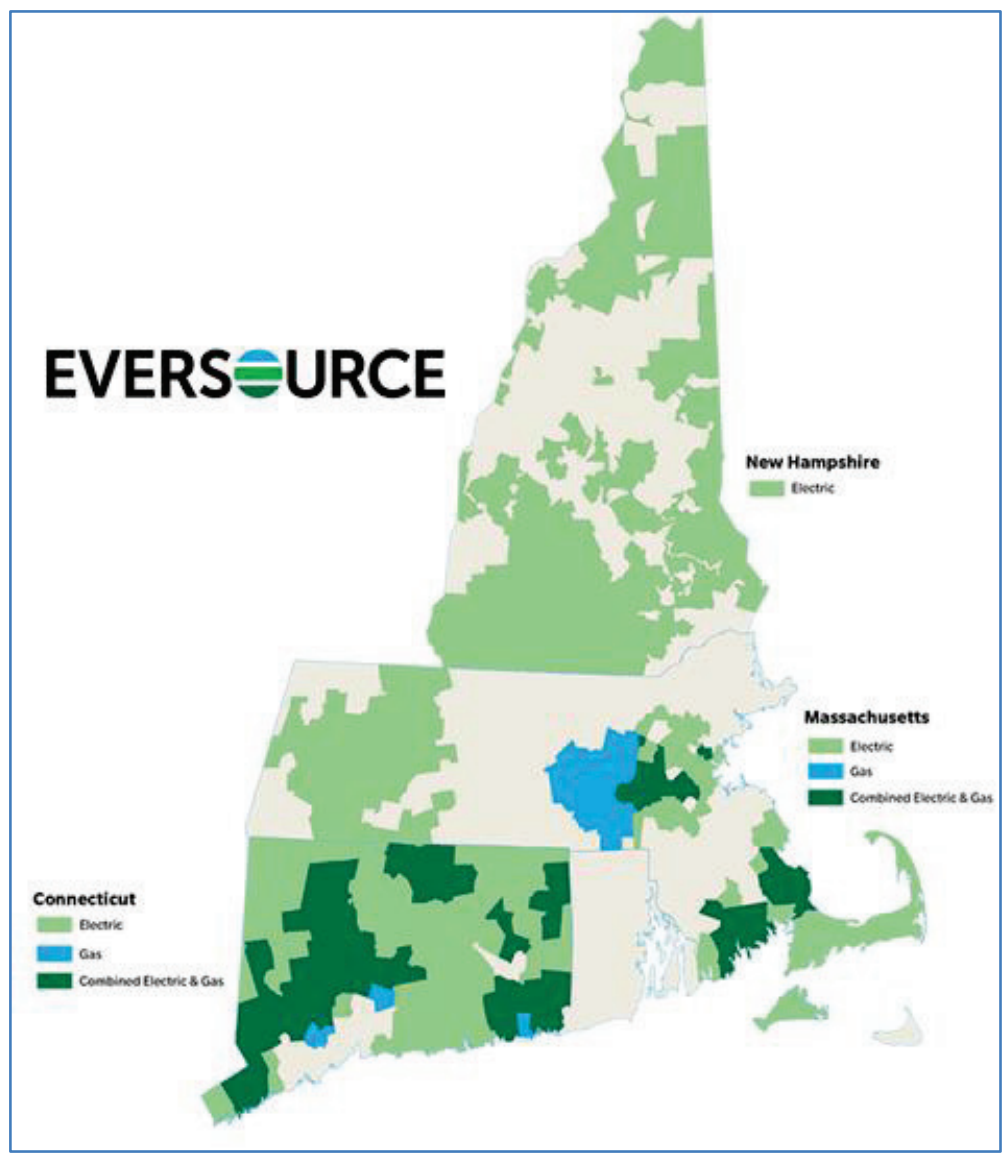

Figure 36. Eversource service territory ${ }^{34}$

Should Camp Edwards pursue a demonstration of MHK technology in the Cape Cod Canal, NREL recommends contacting the Eversource Account Manager to discuss both the options for transmitting the energy from the MHK unit (this concept design) as well as the interconnection requirements for "distributed generation."

The Massachusetts Clean Energy Center (MassCEC), a publicly funded agency dedicated to accelerating the success of clean-energy technologies, has published an "Interconnection Guide for Distributed Generation" 35 that may be helpful for reference. This guide explains the basics of distributed generation and provides detailed information on the Massachusetts interconnection process.

\subsubsection{Other Considerations - Licensing}

In general, the Federal Energy Regulatory Commission (FERC) has governance authority over the licensing of projects that generate electricity from waves or directly from the flow of water in ocean currents, tides, or inland waterways. A FERC license is required to operate a hydrokinetic project on navigable water of the United States. Federal agencies with congressional authorization are the exception.

\footnotetext{
${ }^{34}$ Publicly available service area map, accessed at https://www.eversource.com/Content/ema-c/about/abouteversource/service-territory

35 "Interconnection Guide for Distributed Generation," 2010. Accessed at http://files.masscec.com/uploads/attachments/InterconnectionGuideforDistributedGeneration.pdf
} 
The U.S. Army Corp of Engineers (USACE) bears governance responsibilities for 75 hydro projects and is the largest owner/operator of hydroelectric power plants in the United States. USACE is signatory with FERC on an MOU on Hydro Development (2016). ${ }^{36}$ NREL recommends that Camp Edwards work with USACE to meet all licensing requirements.

\footnotetext{
36 "Memorandum of Understanding between the United States Corps of Engineers and the Federal Energy Regulatory Commission on Non-Federal Hydropower Projects." Effective July 20, 2016. Accessed at https://www.ferc.gov/legal/mou/2016/07-21-16.pdf
} 


\section{Summary \& Conclusions}

This study, conducted through collaboration between the DOE, DOD, and DHS, has identified numerous site where the developing MHK technologies may be able to contribute to long-term agency renewable energy, energy resiliency, and energy security goals.

NREL researchers undertook this study for DOD's Departments of the Army and Air Force, and DHS's U.S. Coast Guard. The study focused on the project development aspects of MHK technologies, overlaying the latest wave and tidal resource data with project development considerations such as electrical infrastructure and environmental constraints, to provide a comprehensive overview of MHK energy generation potential at individual bases. The intent of this study is to provide military and homeland security decision-makers with a realistic view of potential future technology options that can help meet their energy goals, as MHK technologies become commercially viable.

NREL assessed on- and near-base wave and tidal resources and constraints using the methodology described in Section 4 and discussed the findings with the Army, Air Force, and Coast Guard to prioritize sites for further investigation. The Army National Guard's Camp Edwards and the Coast Guard's TRACEN Cape May were down-selected for further resource analysis and on-site investigation.

The USCG conducted targeted and regional vessel traffic studies to further delineate the potential for both future MHK development and potential suitability for developing a research and testing center. These studies pointed to several advantages for the potential tidal energy site near TRACEN Cape May off the southern tip of Cape May. Additionally, USCG considered the potential strategic benefits of enhanced energy resiliency and security to USCG operations across the mid-Atlantic region.

The selected sites were subjects of a more thorough resource modeling assessment performed by the GIT. GIT completed a site-specific numerical simulation performed with the Regional Ocean Modeling System (ROMS), embedded in the Coupled-Ocean-Atmosphere-Wave-Sediment Transport (COAWST) Modeling System. These studies, reported in full in Appendices B and C, resulted in high-resolution maps pointing to areas of highest tidal resource based on tidal flows and bathymetry. The analyses identified areas of specific interest, which served to greatly enhance the level of discussion topics during site visits. The Army, Coast Guard, DOE, and NREL conducted site visits in the spring of 2017 to better understand base operations and to evaluate constraints that might affect potential MHK development/deployment opportunities.

Outcomes of the multiple levels of analyses and site visits include the USCG's interest in further exploring the potential to develop a tidal technology testing facility off the southern tip of Cape May. Also, Camp Edwards has interest in including the potential for MHK siting in long-range base plans as MHK technology develops with improved performance and decreased costs over time.

Overall, there is considerable uncertainty associated with estimating the potential deployability of a still-developing technology at a specific site decades in the future. Changes in any of the parameters used in the screening, such as a new electrical substation, can greatly affect the viability of a site. Similarly, the mission of a base may change, or it may undergo a significant increase or decrease in personnel and energy load.

As MHK technology develops, the cost of deploying these systems will go down and reliability will increase. These combined technological and economic developments may provide DOD and DHS with new ways to meet energy resiliency and security goals while increasing the overall sustainability of their operations. 


\section{References}

Source: Augustine et al. 2012. Renewable Electricity Futures Study: Volume 2 of 4 Renewable Electricity Generation and Storage Technologies. NREL/TP-6A20-52409-2. National Renewable Energy

Laboratory (NREL), Golden, CO (US). http://www.nrel.gov/docs/fy12osti/52409-2.pdf. 


\section{Appendix A. ROM Estimates for Electrical Interconnection}

\section{USCG TRACENCM - Southern Tip at Cape May}

The costs provide here (Table A-1) are for planning purposes, only. These numbers do not include the cost of any marine structure(s) or test-bay, or the cost of the MHK turbine-generator.

Table A-1. Rough Order of Magnitude (ROM) Estimate for Southern Tip Interconnection

\begin{tabular}{|l|r|}
\hline \multicolumn{1}{|c|}{ Description } & ROM Cost \\
\hline Cable, splicing, and installation & $\$ 5,000,000$ \\
\hline Site clearing/preparation, switch pad and land-side site work & $\$ 65,000$ \\
\hline Transformer, switching, load bank and protective equipment & $\$ 250,000$ \\
\hline Power conversion, controller & $\$ 300,000$ \\
\hline A/E Design, Interconnect Study, Permitting & $\$ 125,000$ \\
\hline Testing/commissioning and general conditions & $\$ 70,000$ \\
\hline Estimated Cost & $\$ 5,810,000$ \\
\hline
\end{tabular}

\section{USCG TRACENCM Cape May - Inlet at Cape May}

The costs provide here (Table A-2) are for planning purposes, only. These numbers do not include the cost of any marine structure(s) or test-bay, or the cost of the MHK turbine-generator.

Table A-2. Rough Order of Magnitude (ROM) Estimate for Cape May Inlet Interconnection

\begin{tabular}{|l|r|}
\hline \multicolumn{1}{|c|}{ Description } & ROM Cost \\
\hline Cable, splicing, cable protection and installation & $\$ 450,000$ \\
\hline Site clearing/preparation, switch pad and land-side site work & $\$ 65,000$ \\
\hline Transformer, switching, load bank and protective equipment & $\$ 250,000$ \\
\hline Power conversion and controller & $\$ 300,000$ \\
\hline A/E Design, Interconnect Study, Permitting & $\$ 125,000$ \\
\hline Testing/commissioning and general conditions & $\$ 70,000$ \\
\hline Estimated Total Cost for Inlet Interconnection & $\$ 1,260,000$ \\
\hline
\end{tabular}




\section{Camp Edwards - Cape Cod Canal}

Guidance provided by site personnel and NREL review of available site plans suggest the previously described interconnection. The area east of the Cape Cod Canal, near Jarvis Road, and within the Eversource/NSTAR right-of-way provides ample space and vehicular access for construction and maintenance of controllers (shore-side "balance of plant" equipment).

The costs provided here (Table A-3) are for planning purposes, only. These numbers do not include the cost of any marine structure(s) or test-bay, or the cost of the MHK turbine-generator.

Table A-3. Rough Order of Magnitude (ROM) Estimate for Cape Cod Canal Interconnection

\begin{tabular}{|l|c|}
\hline \multicolumn{1}{|c|}{ Description } & ROM Cost \\
\hline Cable, splicing, and installation & $\$ 1,000,000$ \\
\hline Site clearing/preparation, switch pad and land-side site work & $\$ 65,000$ \\
\hline Transformer, switching, load bank and protective equipment & $\$ 250,000$ \\
\hline Power conversion, controller & $\$ 300,000$ \\
\hline A/E Design, Interconnect Study, Permitting & $\$ 125,000$ \\
\hline Testing/commissioning and general conditions & $\$ 70,000$ \\
\hline \multicolumn{2}{|c|}{ UNIT-TO-SHORESIDE - SUB-TOTAL } \\
\hline Feeder Connection- Onshore to Otis Bulk Feeder Sub. (4-mi.) & $\$ 1,810,000$ \\
\hline $\begin{array}{l}\text { Bay-module, complete with 1200A circuit breaker, air-insulated } \\
\text { disconnects, and protection }\end{array}$ & $\$ 720,000$ \\
\hline SHORESIDE-TO-OTIS FEEDER SUBSTATION-SUB-TOTAL & $\$ 75,000$ \\
\hline & $\$ 795,000$ \\
\hline & $\$ 650,000$ \\
\hline Estimated Cost & $\$ 3,255,000$ \\
\hline
\end{tabular}




\section{Appendix B. Tidal Modeling - TRACEN Cape May}

The NOAA nautical chart below frames the discussion, modeling efforts, and resultant maps in the waters surrounding Cape May.

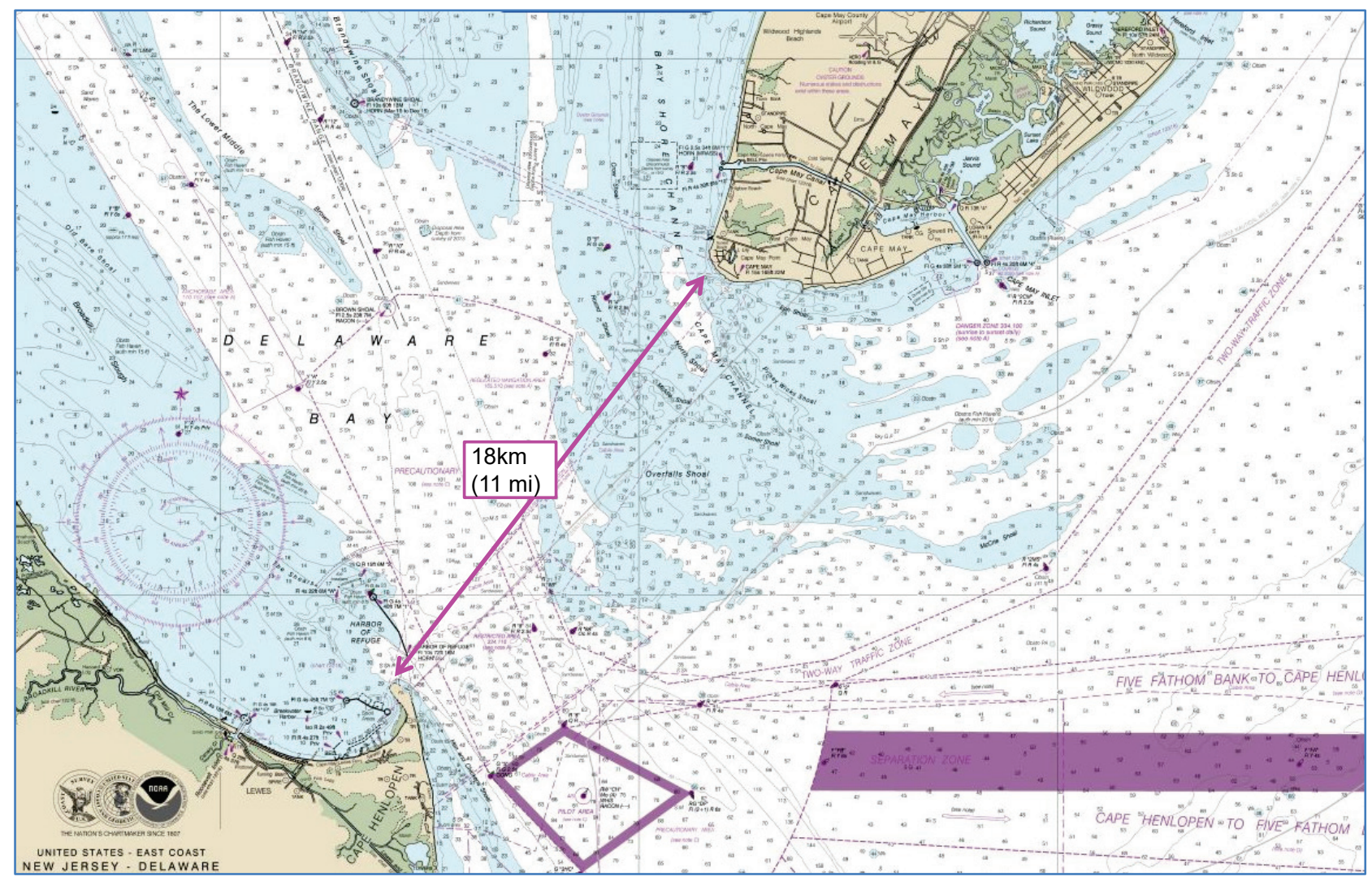

Figure B-1. NOAA nautical chart $12214^{37}$ of Delaware Bay

The same chart zoomed in to the southern tip of Cape May in shown in Figure below.

${ }^{37}$ Office of Coast Survey, National Oceanographic and Atmospheric Administration, Web source:

http://www.charts.noaa.gov/OnLineViewer/12214.shtml 


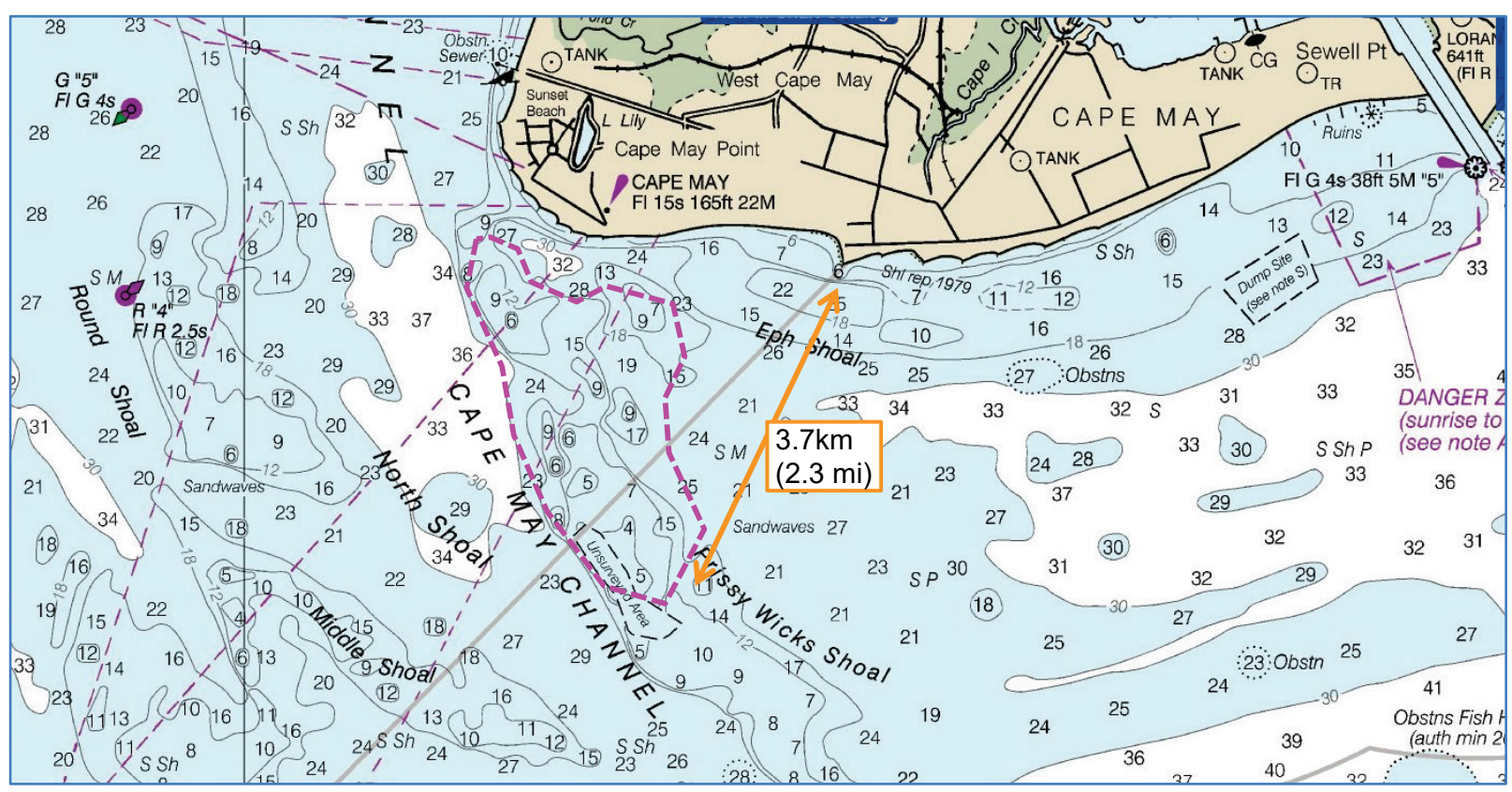

Figure B-2. Zoomed-in NOAA nautical chart 20114 for the southern tip of Cape May

The following section, pp. 66-79, was authored by Tongtong Xu and Kevin A. Haas of Georgia Institute of Technology and produced under contract for this resource assessment effort for NREL and DOD.

A U.S. Coast Guard Station is located at Cape May, New Jersey, a peninsula separating Delaware Bay from the Atlantic Ocean (Figure B-3 (a) and (b)). Tidal currents are potentially significant near the southern tip of the peninsula and within the Cape May Harbor. However, the existing national tidal energy assessment at http://www.tidalstreampower.gatech.edu/ is insufficient in model resolution to detail the tidal currents in the vicinity of the Coast Guard Station, especially the Cape May Harbor and the canal that connects the harbor with Delaware Bay. Therefore, this study uses a numerical model with much higher resolution to better evaluate the tidal flows in the vicinity of the Coast Guard Station.

(a)

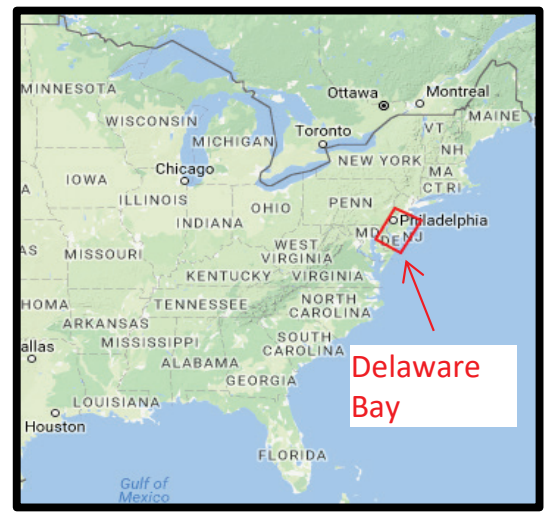

(b)

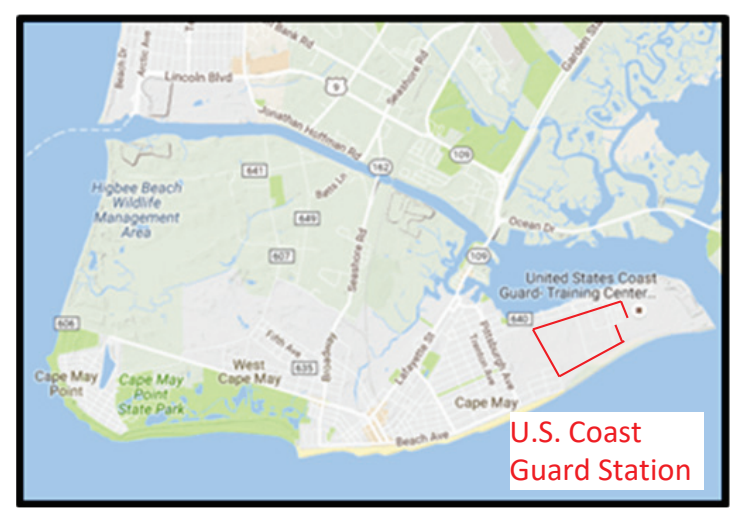

Figure B-3. Maps of interested areas highlighted in red: (a) Delaware Bay in the scope of the U.S. east coast; (b) U.S Coast Guard Station at Cape May, New Jersey 


\section{B.1. Model Set-up - TRACENCM}

The numerical simulation is performed with the Regional Ocean Modeling System (ROMS), embedded in the Coupled-Ocean-Atmosphere-Wave-Sediment Transport (COAWST) Modeling System $^{1}$. COAWST provides a model system that can, as indicated by its name, exchange data fields between the ocean model ROMS, the atmosphere model WRF (Weather Research and Forecasting model), the wave model SWAN (Simulating WAves Nearshore) and the community sediment transport model. In this study, the ocean component ROMS was configured to be standalone in computation, since the objective is to resolve tidal driven currents. ROMS is a member of a general class of three-dimensional, free surface, terrain following numerical models that solve three dimensional Reynolds-averaged Navier-Stokes equations using the hydrostatic and Boussinesq assumptions.

The bathymetry data used in simulation consist of two parts. Bathymetry was extracted and interpolated from the Coastal Relief Model$^{2}$, which is accessible at National Centers for Environmental Information. Topography within the intertidal regions corresponding to wetlands were extracted from The National Map ${ }^{3}$ managed by National Geospatial Program in the U.S. Geological Survey. The wetland bathymetry data are generally referenced to North American Vertical Datum of 1988 (NAVD 88) while the Coastal Relief Model uses mean sea level (MSL), the same as defined by ROMS. Thus, a conversion from NAVD 88 to MSL was performed by Vertical Datum Transformation Software ${ }^{4}$ (VDatum) available from the National Oceanic and Atmospheric Administration (NOAA).

The wetland boundaries are available at the National Wetlands Inventory ${ }^{5}$ of the U.S. Fish and Wildlife Service. Wetland boundaries help to identify grid points that are permanently dry in the mask applied in ROMS. The wetting and drying scheme ${ }^{6}$ which allows for the inundation of the wetlands is activated to determine whether a point is wet or dry in order to achieve a dynamic coastline during the simulation.

The ROMS tidal forcing is generated by interpolating the TPXO8-ATLAS tidal database $\operatorname{model}^{7}$ at the open boundary nodes of the ROMS grid for 13 harmonic constituents, including M2, S2, N2, K2, $\mathrm{K} 1, \mathrm{O} 1, \mathrm{P} 1, \mathrm{Q} 1, \mathrm{M} 4, \mathrm{MS} 4, \mathrm{MN} 4, \mathrm{MM}$ and MF. ROMS is configured to simulate the tidal flows for 32 days, encompassing an entire lunar cycle. Simulation results for the first 2 days are neglected to eliminate the spin up effect of the model.

With the grid refinement techniques, this study applies two grids, a coarser grid covering the entire region of Delaware Bay (Figure B-4) and a finer grid zooming into Cape May (Figure B-5 (a)). The coarser grid is obtained from the model grid which was previously established by the project of Assessment of Energy Production Potential from Tidal Streams in the U.S. ${ }^{8}$ The spatial resolution of each grid point for the coarser grid is approximately $335 \mathrm{~m}$, whereas the resolution of the refined grid is increased by a factor of 5 resulting in a resolution of nearly $65 \mathrm{~m}$. 


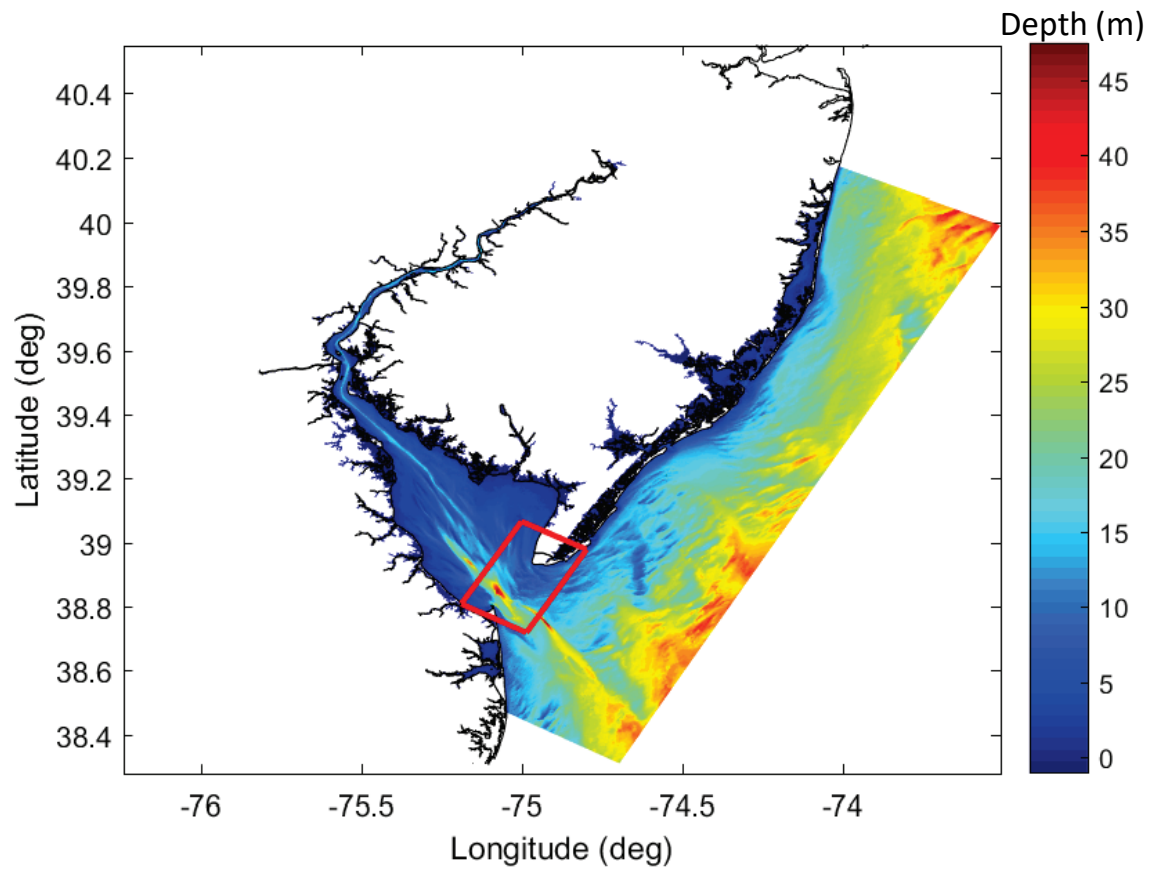

Figure B-4. Model bathymetry of the coarser (parent) grid. Red rectangle marks the region for the refined (child) grid

(a)

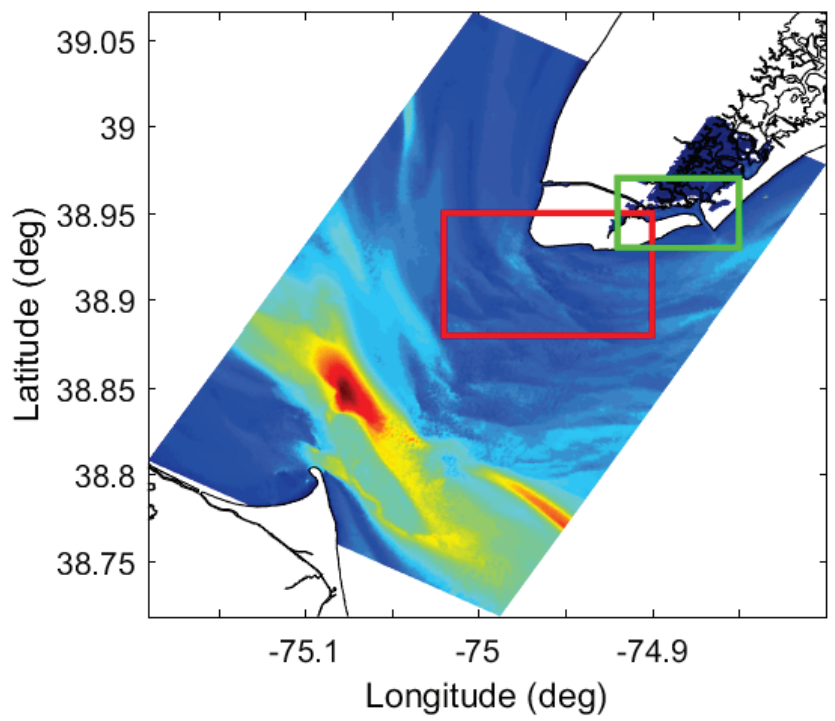

(b)

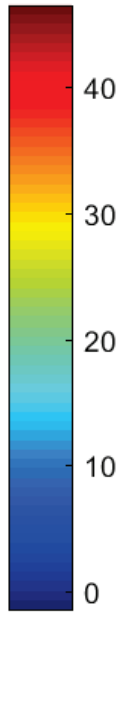

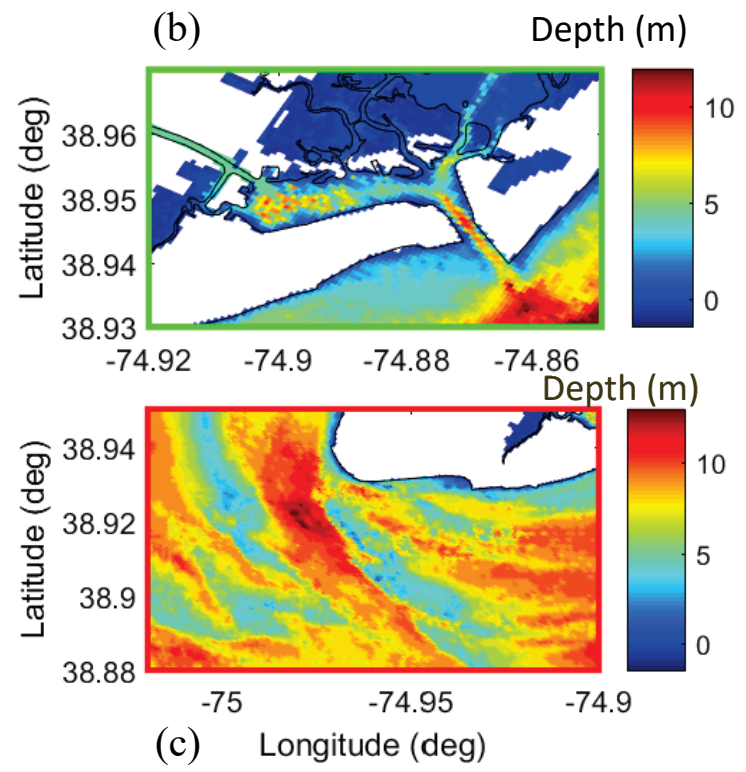

Figure B-5. (a) Model bathymetry of the refined grid. Green and red rectangles outline the two regions of interest. Zoom-in bathymetry of (b) the Cape May Harbor and (c) the Southern Tip of Cape May

Two areas of interest (Figure B-3 (b, c)) are enlarged and shown with their depth variations. The Cape May Canal is too narrow for the bathymetry to be captured by the Coastal Relief Model. Thus, supplementary data are obtained from Electronic Navigational Charts ${ }^{9}$ by Office of Coast Survey and bathymetry within the canal is modified accordingly in both grids. 


\section{B.2. Model Verification - TRACEN Cape May}

Simulation results are validated by extracting tidal constituents with harmonic analysis and comparing tidal components with records from current stations and water level stations obtained from NOAA Tides and Currents ${ }^{10}$. In the refined grid, there are 2 current stations, Station CAM0001 and Station DEB0002, as well as 3 water level stations available, Station 8536110, Station 8535835 and Station 8557380. Locations of each station are mapped in Figure 4. Station CAM0001 is located close to a coastline boundary point within the Cape May Inlet, causing the tidal constituents of simulation results directly from that location unobtainable, thus, the tidal constituents for comparison with Station CAM0001 are extracted from a model grid point at $(-74.872,38.947)$, which is adjacent to the actual location.

Following the method of Defne et al (2012), parameters are calculated to estimate the extent of model over-prediction or under-prediction of the tidal harmonic constituents, including amplitude difference (amd), percentage of amplitude difference (amdp) and phase difference (phd), defined as,

$$
\begin{gathered}
a m d_{k}=\left(a m p_{m}\right)_{k}-\left(a m p_{o}\right)_{k} \\
a m d p_{k}=\frac{\left(a m p_{m}\right)_{k}-\left(a m p_{o}\right)_{k}}{\left(a m p_{o}\right)_{k}} \times 100, \\
p h d_{k}=\left(p h a_{m}\right)_{k}-\left(p h a_{o}\right)_{k}
\end{gathered}
$$

Depth (m)

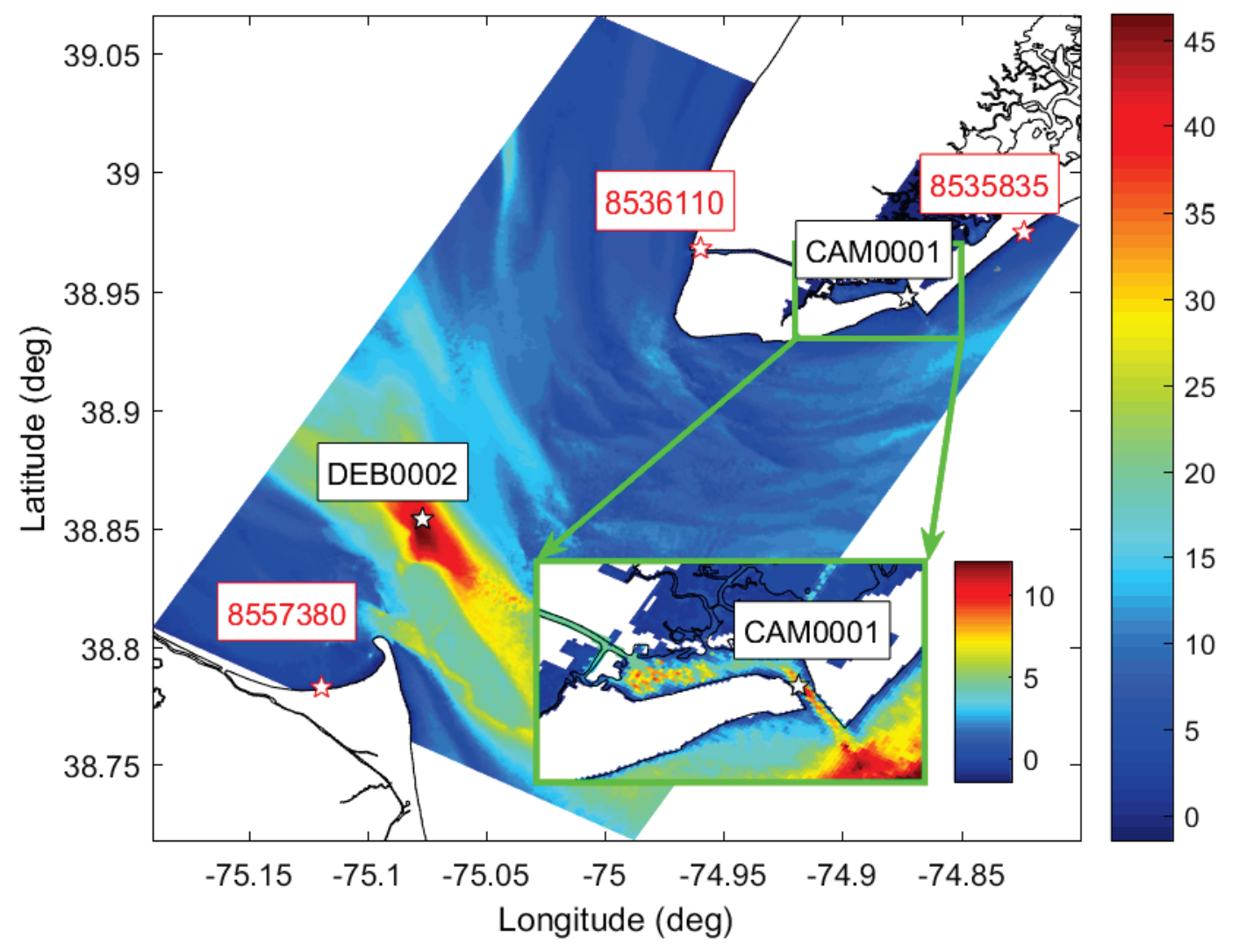

Figure B-6. Model bathymetry of the refined grid. Stars with edge color in red mark locations of tidal harmonic data. Stars with edge color in black mark locations of current stations. Zoom in view of the bathymetry helps clarify the location of the Station CAM0001. 
in which $(a m p)_{k}$ and $(p h a)_{k}$ mean the amplitude and the phase of the $k$ th harmonic constituent, respectively. Subscript $m$ and $o$ represent calculation from model output and the observation data, respectively. For current stations, $(a m p)_{k}$ is calculated as,

$$
(a m p)_{k}=\sqrt{\left(a_{m a j}^{2}\right)_{k}+\left(a_{m i n}^{2}\right)_{k}}
$$

where $a_{m a j}$ and $a_{\min }$ are the major and the minor axis amplitudes of the tidal ellipse. Also, another parameter called tidal ellipse inclination difference (incd) is calculated between the current stations and the same locations of model output, defined as,

$$
\operatorname{incd}_{k}=\left(i n c_{m}\right)_{k}-\left(i n c_{o}\right)_{k},
$$

in which $(i n c)_{k}$ is the orientation of the tidal ellipse of the $k$ th harmonic constituent (measured in degrees, anti-clockwise from East to the semi-major axis of a tidal ellipse).

Verifications for each water level and tidal currents stations are listed from Table B-1 to B-5. In general, the model simulation results are consistent with the observation records with errors for the major constituents well under $10 \%$.

Table B-1. Verification of tidal current harmonic constituents for Station CAM0001 (-74.8727, 38.9475)

\begin{tabular}{|c|c|c|c|c|c|c|c|c|}
\hline Constituent & Period & amp & amd & amdp & inc & incd & pha & phd \\
\hline & (hrs) & $(\mathrm{m} / \mathrm{s})$ & $(\mathrm{m} / \mathrm{s})$ & $(\%)$ & (deg) & (deg) & (min) & $(\min )$ \\
\hline M2 & 12.4206 & 0.79 & 0.00 & 0 & 127 & -2 & 295 & -5 \\
\hline S2 & 12 & 0.17 & -0.05 & -30 & 128 & -1 & 318 & 23 \\
\hline N2 & 12.6583 & 0.15 & 0.01 & 3 & 127 & -2 & 277 & 3 \\
\hline M4 & 6.2103 & 0.06 & 0.10 & 178 & 126 & 7 & 5 & 335 \\
\hline K1 & 23.9345 & 0.06 & 0.01 & 12 & 127 & -1 & 98 & 14 \\
\hline 01 & 25.8193 & 0.05 & 0.00 & -6 & 127 & -1 & 89 & 12 \\
\hline M6 & 4.1402 & 0.04 & 0.04 & 119 & 126 & 5 & 349 & -6 \\
\hline Q1 & 26.8684 & 0.01 & 0.00 & -21 & 126 & -5 & 84 & 8 \\
\hline
\end{tabular}
CAM0001 (-74.8727, 38.9475)

Table B-2. Verification of tidal current harmonic constituents for Station DEB0002 (-75.077, 38.85362) DEB0002 (-75.077, 38.85362)

\begin{tabular}{|c|c|c|c|c|c|c|c|c|}
\hline Constituent & $\begin{array}{c}\text { Period } \\
\text { (hrs) }\end{array}$ & $\begin{array}{c}\text { amp } \\
(\mathrm{m} / \mathrm{s})\end{array}$ & $\begin{array}{c}\text { amd } \\
(\mathrm{m} / \mathrm{s})\end{array}$ & $\begin{array}{c}\text { amdp } \\
(\%)\end{array}$ & $\begin{array}{c}\text { inc } \\
(\mathrm{deg})\end{array}$ & $\begin{array}{c}\text { incd } \\
(\mathrm{deg})\end{array}$ & $\begin{array}{c}\text { pha } \\
(\mathrm{min})\end{array}$ & $\begin{array}{c}\text { phd } \\
(\mathrm{min})\end{array}$ \\
\hline $\mathbf{M} 2$ & 12.4206 & 0.74 & -0.10 & -13 & 118 & 3 & 349 & -7 \\
\hline $\mathbf{N 2}$ & 12.6583 & 0.17 & -0.03 & -20 & 116 & 5 & 312 & 18 \\
\hline $\mathbf{S 2}$ & 12 & 0.09 & 0.01 & 10 & 120 & 1 & 25 & 8 \\
\hline $\mathbf{K 1}$ & 23.9345 & 0.09 & -0.02 & -22 & 114 & 7 & 151 & -2 \\
\hline $\mathbf{M} 4$ & 6.2103 & 0.06 & -0.05 & -77 & 78 & 29 & 338 & -119 \\
\hline $\mathbf{M} 1$ & 25.8193 & 0.05 & -0.01 & -25 & 117 & 4 & 133 & 8 \\
\hline $\mathbf{Q 1}$ & 4.1402 & 0.03 & -0.03 & -85 & 82 & 63 & 326 & -13 \\
\hline
\end{tabular}


Table B-3. Verification of tidal water level harmonic constituents for Station $8536110(-74.9599,38.96784)$ 8536110 (-74.9599, 38.96784)

\begin{tabular}{|c|c|c|c|c|c|}
\hline Constituent & Period & amp & amd & amdp & phd \\
\hline & $(\mathrm{hrs})$ & $(\mathrm{m})$ & $(\mathrm{m})$ & $(\%)$ & (min) \\
\hline M2 & 12.4206 & 0.714 & 0.04 & 5 & -3 \\
\hline N2 & 12.65835 & 0.159 & -0.01 & -4 & 2 \\
\hline S2 & 12 & 0.125 & -0.02 & -14 & 19 \\
\hline O1 & 23.93447 & 0.105 & 0.01 & 10 & -2 \\
\hline Q1 & 25.81934 & 0.084 & -0.02 & -23 & 4 \\
\hline M4 & 26.86836 & 0.013 & 0.00 & -5 & -2 \\
\hline M6 & 6.2103 & 0.01 & 0.01 & 67 & 62 \\
\hline
\end{tabular}

Table B-4. Verification of tidal water level harmonic constituents for Station $8535835(-74.8233,38.975)$ 8535835 (-74.8233, 38.975)

\begin{tabular}{|c|c|c|c|c|c|}
\hline Constituent & Period & amp & amd & amdp & phd \\
\hline & (hrs) & $(\mathrm{m})$ & $(\mathrm{m})$ & $(\%)$ & (min) \\
\hline M2 & 12.4206 & 0.626 & -0.01 & -1 & 1 \\
\hline N2 & 12.65835 & 0.148 & -0.01 & -9 & 4 \\
\hline K1 & 12 & 0.127 & -0.03 & -26 & 23 \\
\hline O1 & 23.93447 & 0.114 & -0.01 & -4 & 4 \\
\hline Q1 & 25.81934 & 0.084 & -0.02 & -27 & 11 \\
\hline M4 & 26.86836 & 0.016 & 0.00 & -24 & 8 \\
\hline M6 & 6.2103 & 0.008 & 0.01 & 146 & 10 \\
\hline
\end{tabular}

Table B-5. Verification of tidal water level harmonic constituents for Station $8557380(-75.1192,38.78278)$ 8557380 (-75.1192, 38.78278)

\begin{tabular}{|c|c|c|c|c|c|}
\hline Constituent & Period & amp & amd & amdp & phd \\
\hline & $(\mathrm{hrs})$ & $(\mathbf{m})$ & $(\mathrm{m})$ & $(\%)$ & (min) \\
\hline M2 & 12.4206 & 0.616 & 0.02 & 3 & -1 \\
\hline N2 & 12.65835 & 0.134 & 0.00 & -1 & 4 \\
\hline K2 & 12 & 0.108 & -0.02 & -14 & 20 \\
\hline O1 & 23.93447 & 0.103 & 0.01 & 9 & 0 \\
\hline M4 & 25.81934 & 0.083 & -0.02 & -24 & 5 \\
\hline Q1 & 26.2103 & 0.013 & 0.01 & 39 & 13 \\
\hline M6 & 4.140836 & 0.013 & 0.00 & -7 & 1 \\
\hline
\end{tabular}




\section{B.3. Tidal Energy Assessment - TRACENCM}

For the resource assessment based on the model simulation data, we follow the guidelines from the International Electrotechnical Commission (IEC) Technical Specification for tidal energy resource assessments. ${ }^{11}$

The spatial variation of the depth averaged current speed from the refined grid is shown in Figure B-7. The enlarged views of the depth averaged current speed are shown for Cape May Harbor in Figure B-8 and for the Southern Tip of Cape May in Figure B-9 with the same geographic range as Figure B-5 (b) and (c), respectively. A similar set of figures is shown in Figure B-10, B-11, B-12 for the maximum depth averaged current speed. As shown in Figure B-6, the depth averaged currents rapidly accelerate when approaching and passing through the Cape May Harbor. Currents move faster in the narrow channel to satisfy mass conservation. The water storage in wetlands increase the volume of flooded region and enhance the current speed near the Cape May Harbor inlet. The maximum depth averaged currents in Figure B-11 show a similar pattern but with almost a double magnitude compared with the mean depth averaged currents in Figure B-8.

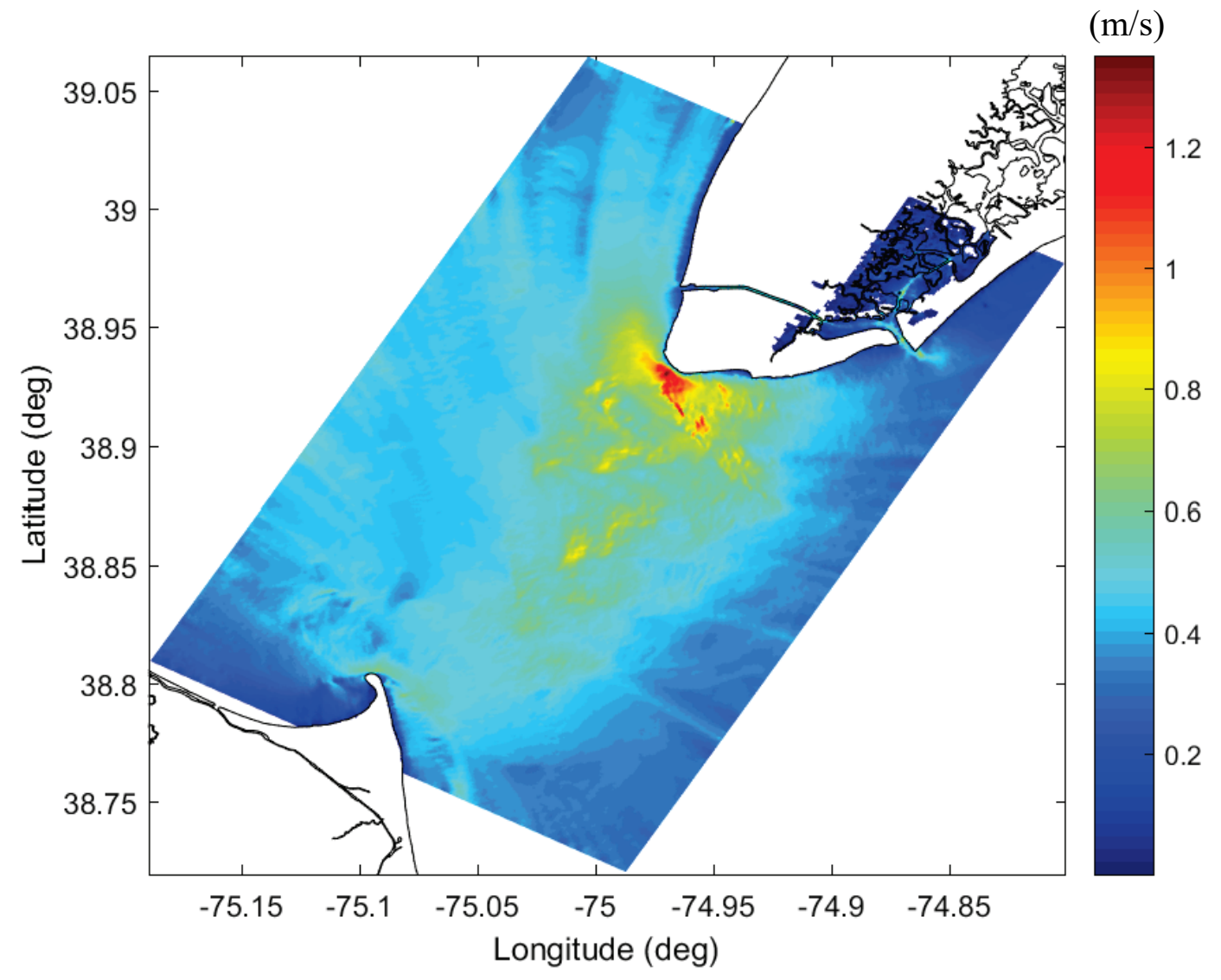

Figure B-7. Depth averaged current speed from the refined grid 
$(\mathrm{m} / \mathrm{s})$

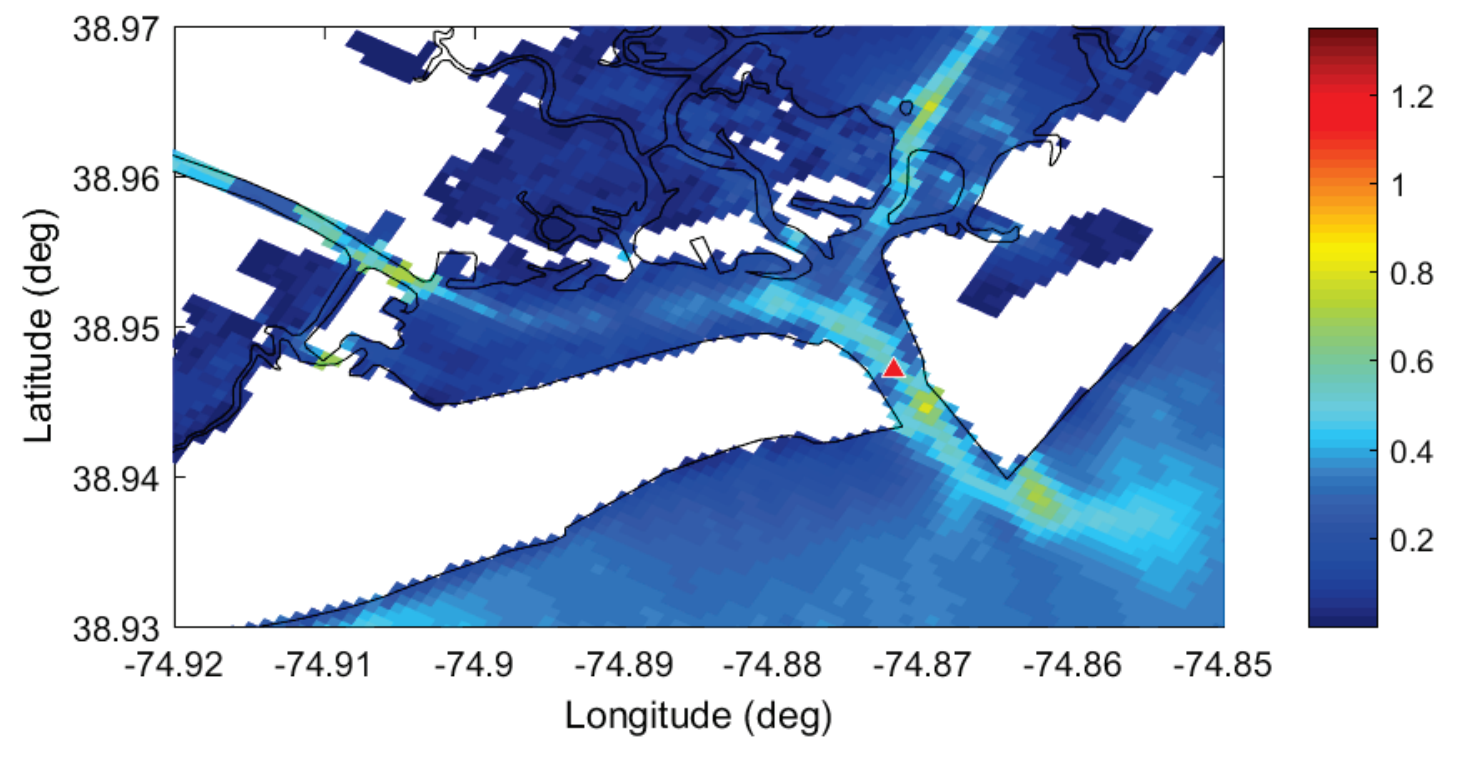

Figure B-8. Zoom-in view of the depth averaged current speed for Cape May Harbor. Triangle marks the location for evaluating AEP density.

$$
(\mathrm{m} / \mathrm{s})
$$

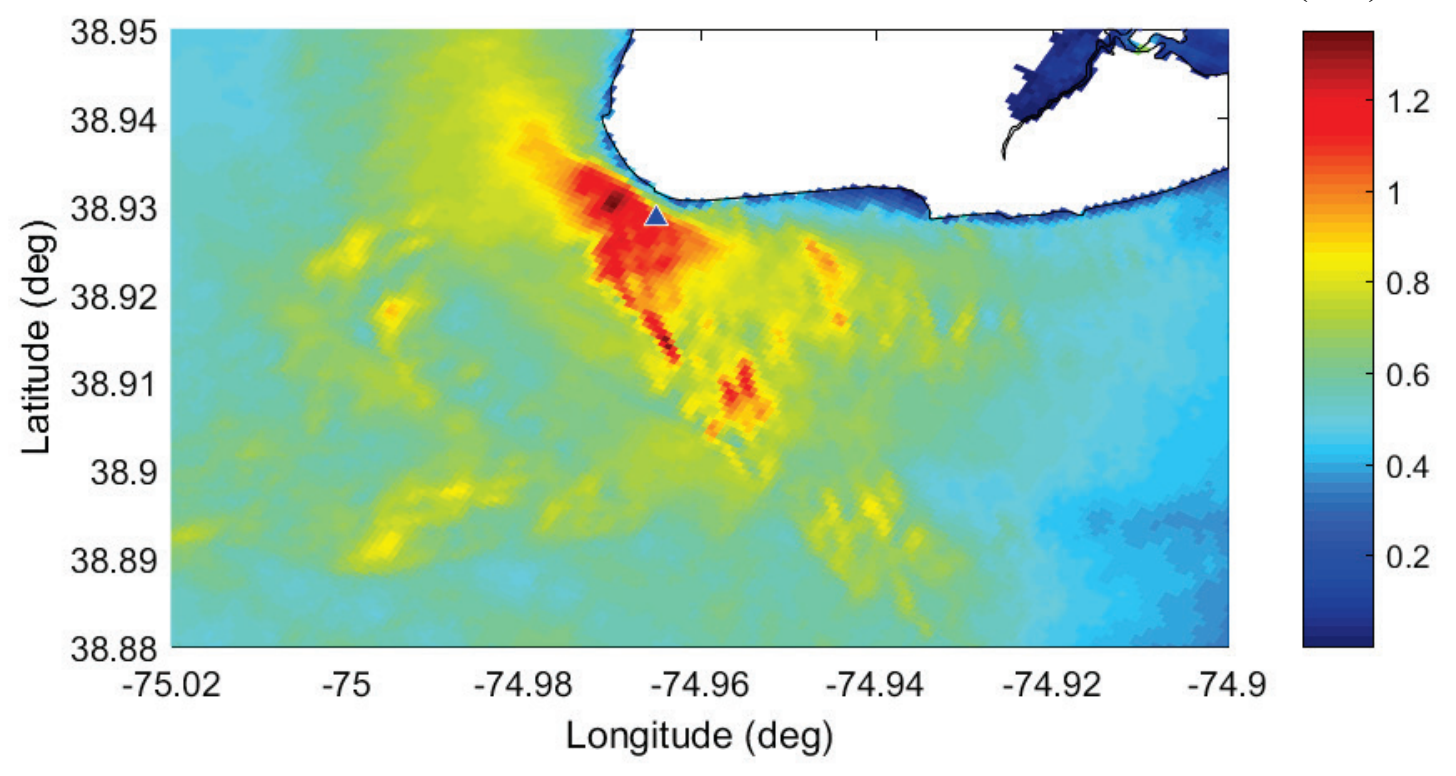

Figure B-9. Zoom-in view of the depth averaged current speed for the Southern Tip of Cape May. Triangle marks the location for evaluating AEP density. 
$(\mathrm{m} / \mathrm{s})$

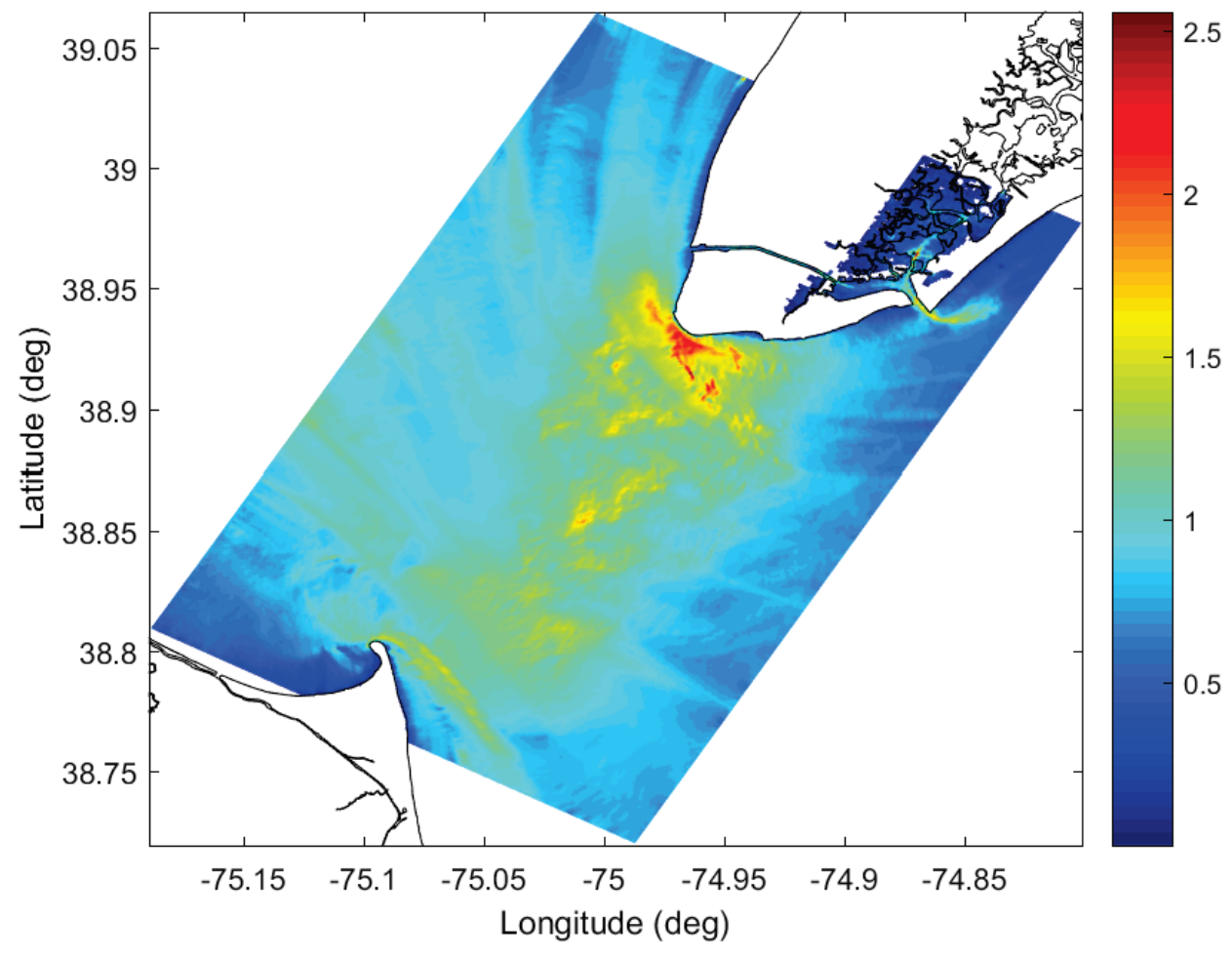

Figure B-10. Maximum depth averaged current speed from the refined grid

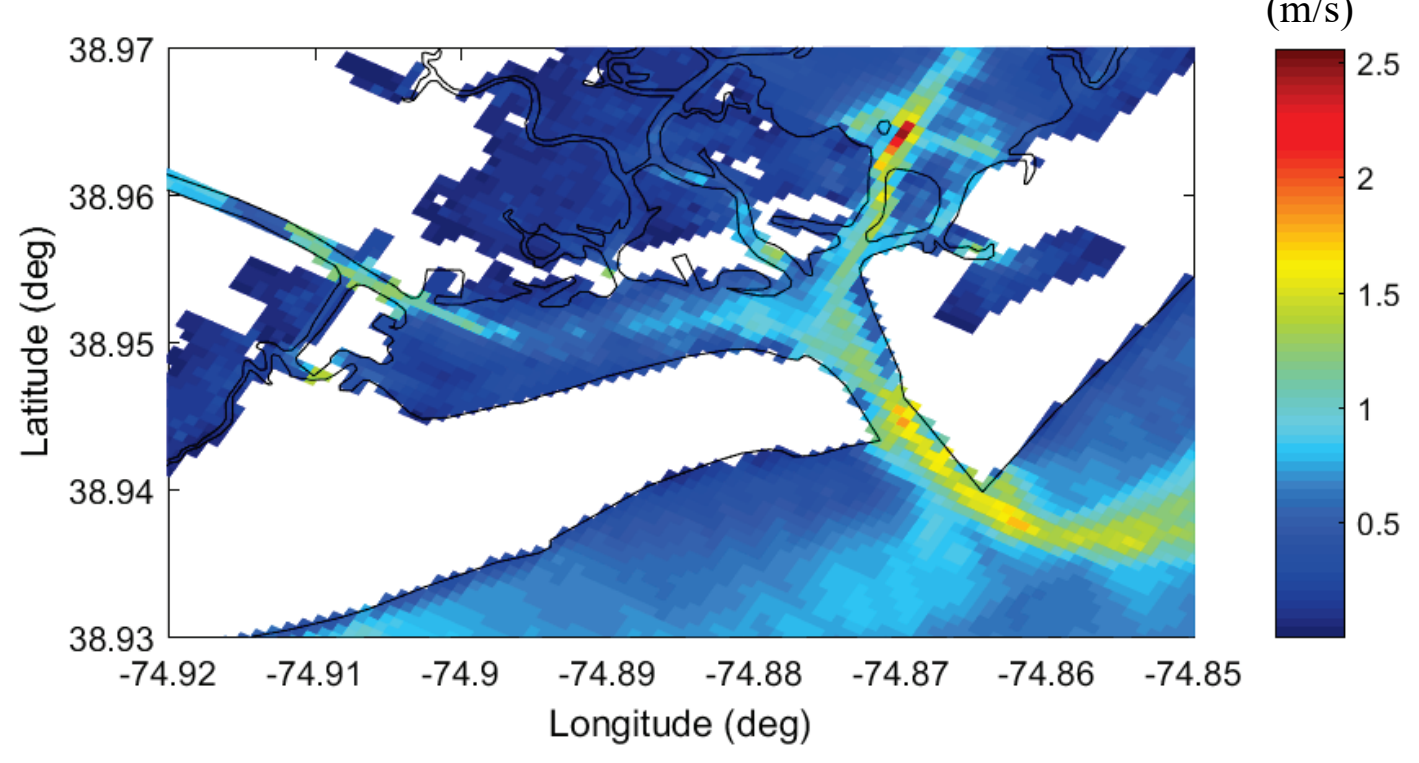

Figure B-11. Zoom-in view of the maximum depth averaged current speed for Cape May Harbor

As shown in Figure B-9, the depth averaged current speed is significantly increased near the southernmost point of Cape May, producing the strongest currents in the refined grid. Due to the existence of the Cape May peninsula, currents are forced to flow along the coastline, resulting in a flow acceleration to maintain the water movement across the southernmost point. The maximum depth averaged currents in Figure B-12 again show a double magnitude of the mean depth averaged currents in Figure B-9. 


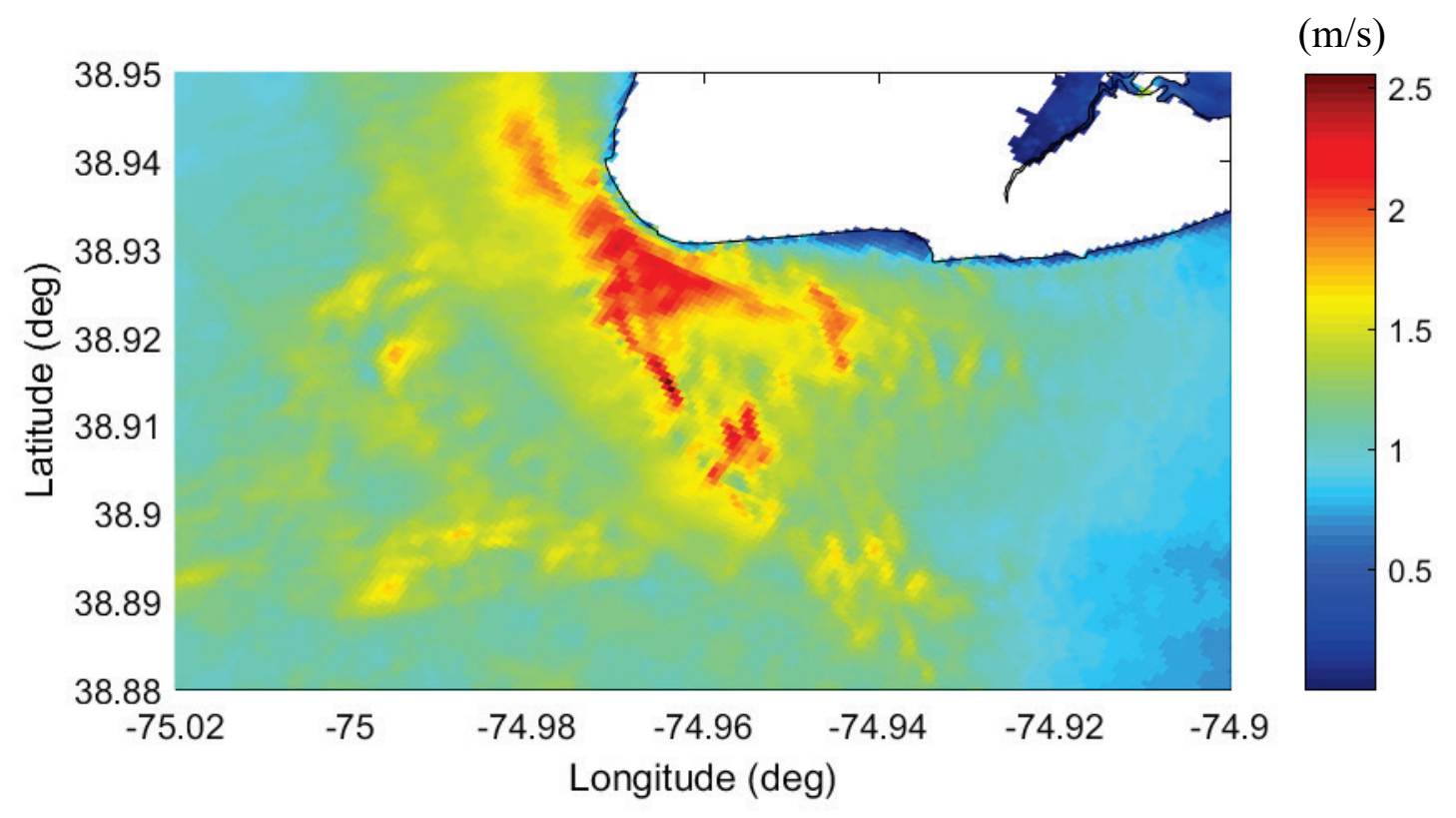

Figure B-12. Zoom-in view of the maximum depth averaged current speed for the Southern Tip of Cape May

The tidal constituents are computed from the month-long model simulation velocity data, and these constituents are used to compute a full year time series of the velocity with 10-minute temporal resolution. This new time series data is used to develop the probability distribution of the velocity based on the method of bins (10 cm/s bins). ${ }^{11}$ As marked in Figure B-8, B-9, two locations with relatively large currents are selected for assessing power density and AEP density, one in Cape May Inlet and one near the southern tip of Cape May. Histograms of depth averaged current velocity magnitudes are included for these two locations in Figure B-13, showing that the current magnitude is higher at southern tip of Cape May.

From joint direction and magnitude probability distributions shown in Figure B-14 (a), it is seen that the major current direction is from northwest and southeast at Cape May Inlet, which is consistent with the inlet orientation. In other words, due to the constraint by the inlet geometry, currents passed by are guided to flow in either northwest or southeast directions. The major currents at the southern tip of Cape May (Figure B-14 (b)) are approached from directions closer to the east and west direction, although flood and ebb are not symmetric. The exceedance curves for the two locations are shown in Figure B-15. Based on the minimum cut-in speed associated with a particular turbine, the exceedance curve identifies the proportion of time that turbine could operate.

The available tidal energy density (energy per unit cross-sectional area) is computed for each velocity bin from the probability distribution as,

$$
P_{k}=\frac{1}{2} \rho\left|V_{k}\right|^{3}
$$

in which $\rho$ is the seawater density take as a constant at $15^{\circ} \mathrm{C}$ and 35 PPT salinity $(\rho=$ $\left.1025 \mathrm{~kg} / \mathrm{m}^{3}\right) . V_{k}$ is the depth averaged current speed for bin $\mathrm{k}$.

The IEC guidelines provide a methodology for computing the Annual Energy Production (AEP) using the velocity distribution together with a power curve for the turbine. Here, because we are 
not using a particular turbine, we use the same methodology to calculate the Annual Available Energy (AAE) density, which quantifies how much energy in the flow field is available per unit cross-sectional area,

$$
A A E=N_{h} \cdot \sum_{k=1}^{N_{B}} P_{k} \cdot f_{k}
$$

in which $N_{h}$ is the number of hours in the simulated year. $f_{k}$ is the probability density function (PDF) from the method of bins to group the depth-averaged current speed. $N_{B}$ is the total number of bins. AAE density at Cape May Inlet is equal to $1.0995 \mathrm{MWh}$ per $\mathrm{m}^{2}$; AAE density at southern tip of Cape May is 9.4017 MWh per $\mathrm{m}^{2}$.

(a)

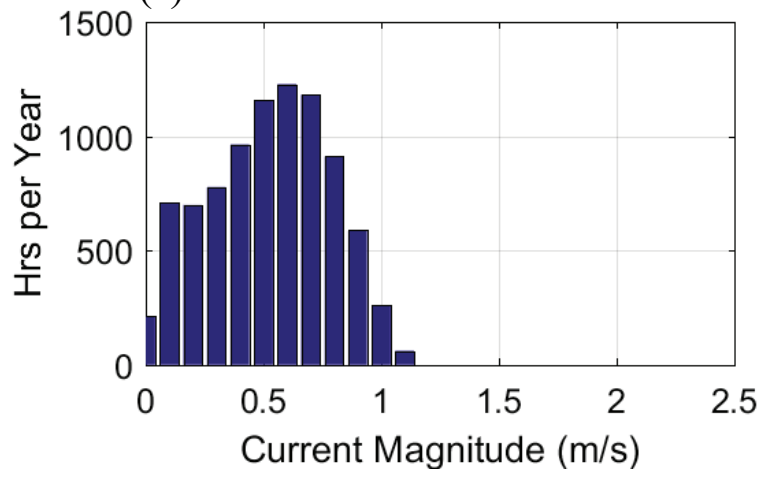

(b)

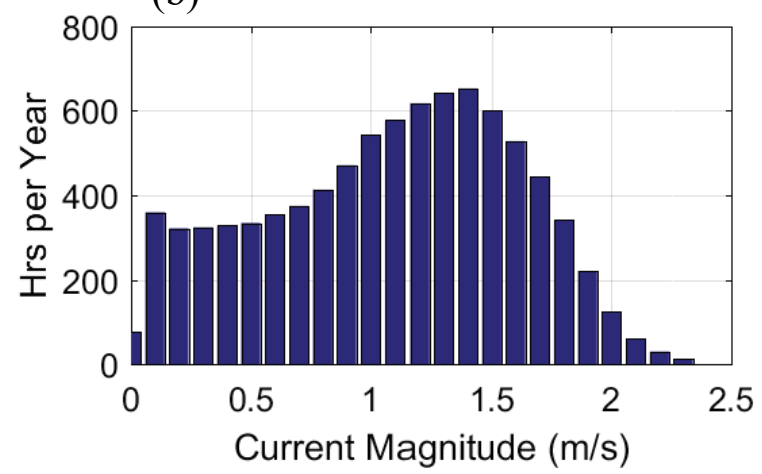

Figure B-13. Histogram of depth averaged current velocity magnitudes for (a) Cape May Inlet and (b) the southern tip of Cape May
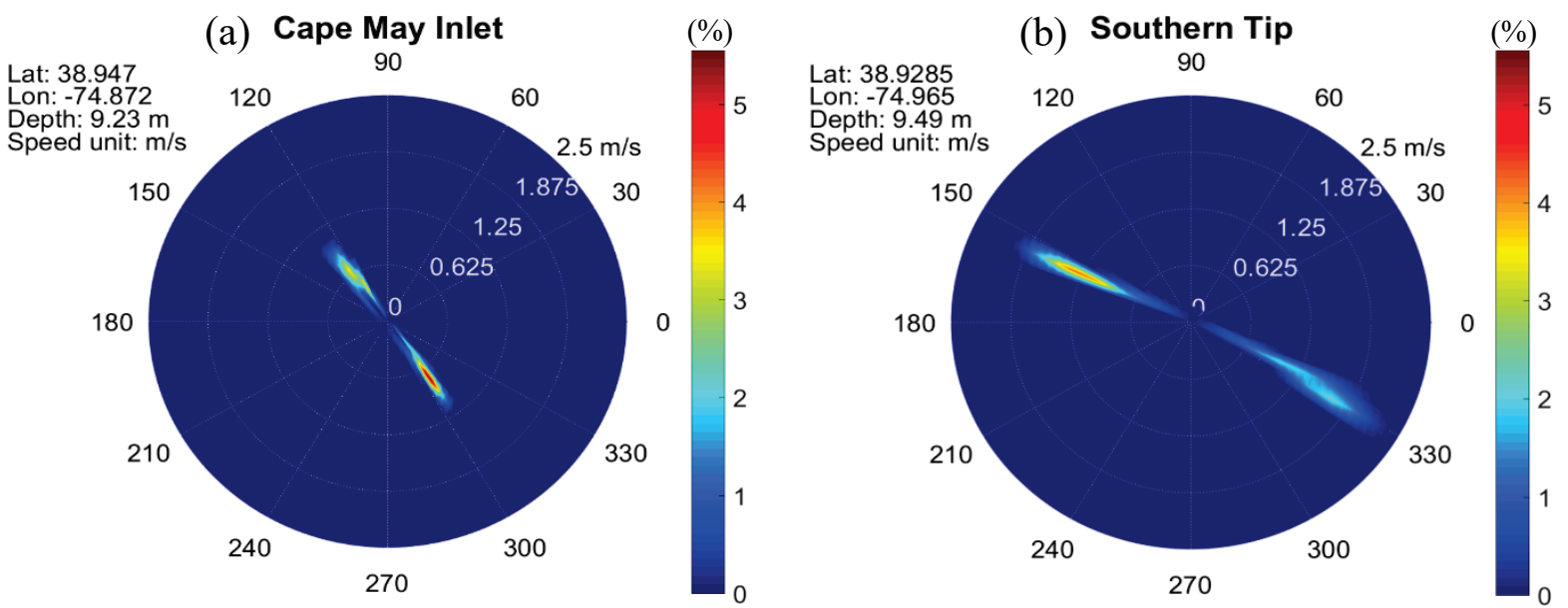

Figure B-14. Joint PDF of velocity and direction for (a) Cape May Inlet and (b) Southern Tip of Cape May 


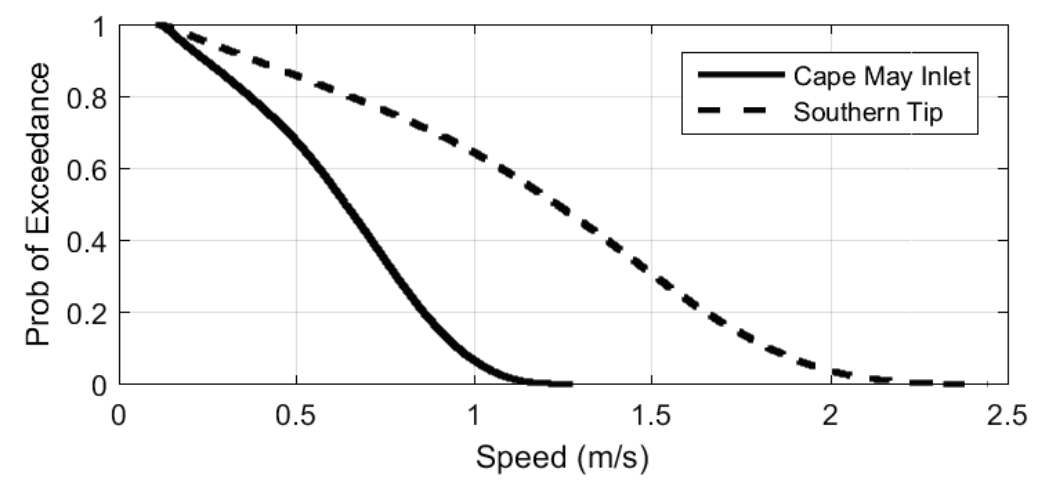

Figure B-15. Exceedance curve for current speed at Cape May Inlet and southern tip

\section{B.4. Summary - TRACENCM}

This study investigates the flow details of tidal currents and the tidal energy availability near a U.S. Coast Guard Station at Cape May, New Jersey. The assessment is accomplished through the COAWST modeling system ${ }^{1}$ using the grid refinement techniques. A new and finer grid combined with a previously established coarser grid $^{8}$ is generated to simulate tidal flows for 32 days, encompassing an entire lunar cycle. The wetting and drying scheme ${ }^{6}$ is activated to account for water storage in wetland intertidal regions. Simulation results are validated by extracting tidal constituents with harmonic analysis and comparing with NOAA observations ${ }^{10}$. Depth averaged currents are strong near the Cape May Inlet and the Southern Tip of Cape May, demonstrating the need for assessing tidal flows near the Coast Guard Station of Cape May. Following the guidelines from IEC Technical Specification for tidal energy resource assessment, tidal constituents from the month-long model simulation are used to compute a full year time series of current velocities. The velocity probability distributions and the AAE density is determined to be $1.0964 \mathrm{MWh}^{2} \mathrm{~m}^{2}$ at the Cape May Inlet and $9.4017 \mathrm{MWh}$ per $\mathrm{m}^{2}$ at the southern tip of Cape May. This represents the amount of energy that is available for conversion to electricity at two particular locations and can be converted to the available energy for a particular device by multiplying it by the device rotor swept area. However, it is important to note that the actual electricity generated (AEP) would be some fraction of this amount once the turbine and transmission efficiencies are taken into account. In addition, if a relatively large number of devices are to be deployed, then the model simulations would need to be redone including the extra dissipation due to energy extraction. 


\section{References}

${ }^{1}$ J. C. Warner, B. Armstrong, R. Y. He, and J. B. Zambon, "Development of a coupled oceanatmosphere-wave-sediment transport (COAWST) modeling system," Ocean Modelling. 35(3), 230-244 (2010).

${ }^{2}$ Coastal Relief Model. National Centers for Environmental Information.

http://maps.ngdc.noaa.gov/vie- wers/wcs-client/ [accessed 2016].

${ }^{3}$ The National Map Download. U.S. Geological Survey. https://viewer.nationalmap.gov/basic/ [accessed 2016].

${ }^{4}$ Vertical Datum Transformation Software. National Oceanic and Atmospheric Administration. http://vdatum.noaa.gov/ [accessed 2016].

${ }^{5}$ National Wetlands Inventory. U.S. Fish and Wildlife Service. https://www.fws.gov/wetlands/data/map-per.html [accessed 2016].

${ }^{6}$ J. C. Warner, Z. Defne, K. A. Haas, and H. G. Arango, "A wetting and drying scheme for ROMS," Computers and Geosciences. 58, 54-61 (2013).

${ }^{7}$ TPXO8-atlas. The OSU TOPEX/Poseidon Global Inverse Solution TPXO. http://volkov.oce.orst.edu/tides-/tpxo8_atlas.html [accessed 2016].

${ }^{8}$ Z. Defne, K. A. Haas, H. M. Fritz, L. Jiang, S. P. French, X. Shi, B. T. Smith, V. S. Neary and K. M. Stewart "National geodatabase of tidal stream power resource in USA," Renewable and Sustainable Energy Reviews. 16, 3326-3338 (2012).

${ }^{9}$ Electronic Navigational Charts. Office of Coast Survey. http://www.charts.noaa.gov/InteractiveCatalog-/nrnc.shtml\#mapTabs-2 [accessed 2016].

${ }^{10}$ Tides and Currents Products. National Oceanic and Atmospheric Administration. https://tidesandcurr-ents.noaa.gov/products.html [accessed 2016].

${ }^{11}$ Marine energy-Wave tidal and other water current converters-Part 201: Tidal energy resource assessment and characterization. International Electrotechnical Commission Technical Specification (2015). 


\section{Appendix C. Tidlal Modeling - Camp Edwards}

The NOAA nautical chart below frames the discussion, modeling efforts, and resultant maps in the water of interest in Cape Cod Canal adjacent to Camp Edwards.

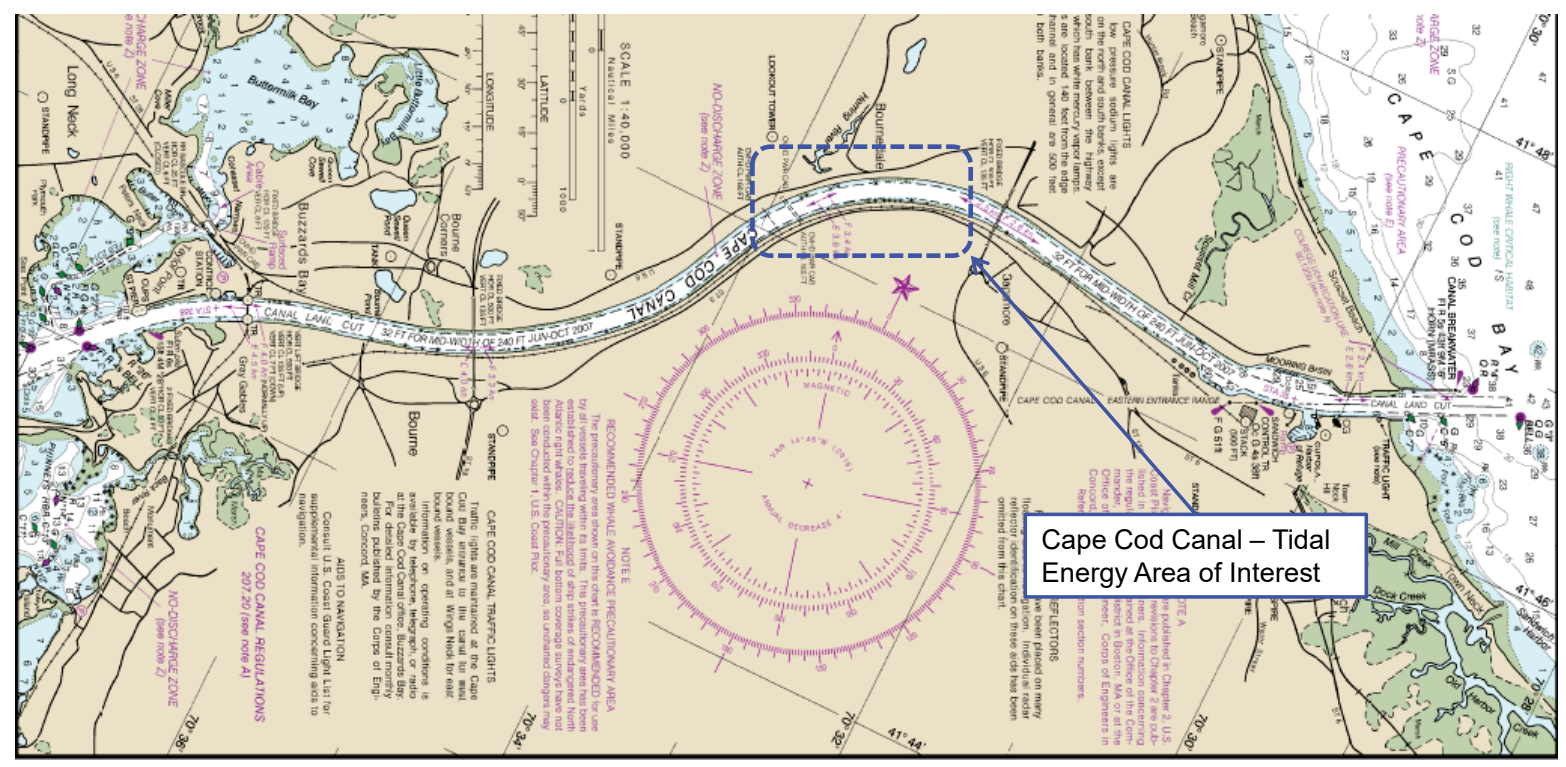

Figure C-1. NOAA nautical chart 13229 of the Cape Cod Canal area

The following section, pp. 80-90, was authored by Tongtong Xu and Kevin A. Haas of Georgia Institute of Technology and was produced under contract for this resource assessment effort for NREL and the DOD.

The Joint Base Cape Cod is a comprehensive military training center located at the western portion of Cape Cod, Massachusetts, adjacent to Cape Cod Canal, an artificial waterway separating Cape Cod from the state's mainland (Figure C-2). Camp Edwards, with a base border within close proximity of the canal, is the primary location of interest with the joint base. As the canal connects Cape Cod Bay in the northeast and Buzzards Bay in the southwest, tidal currents through the canal could be significant if the water level within these two bays are modulated with a relative time lag. The abundance of historical data from tidal current and water level stations within the canal enables the computationally efficient option to create a small yet high resolution computational domain containing only the canal and directly input the water level on either side as a boundary condition. Therefore, this study uses a numerical model with a single, high-resolution grid forced by water level variations derived from tidal constituents based on historical records to simulate tidal flows through the canal in the vicinity of the Joint Base Cape Cod.

\section{C.1. Model Set-up - Camp Edwards}

The numerical simulation is performed with the Regional Ocean Modeling System (ROMS), embedded in the Coupled-Ocean-Atmosphere-Wave-Sediment Transport (COAWST) Modeling System. ${ }^{1}$. COAWST provides a model system that can, as indicated by its name, exchange data fields between the ocean model ROMS, the atmosphere model WRF (Weather Research and Forecasting model), the wave model SWAN (Simulating WAves Nearshore) and the community sediment transport model. In this study, the ocean component ROMS was configured to be standalone in computation, since the objective is to resolve tidal driven currents. ROMS is a member of a general class of three-dimensional, free surface, terrain following numerical models that solve 
three dimensional Reynolds-averaged Navier-Stokes equations using the hydrostatic and Boussinesq assumptions.

The bathymetry of the Cape Cod Canal was obtained from the Army Corps of Engineers and is shown in Figure C-3. The datum of original bathymetry is referenced to mean lower low water (MLLW) while ROMS uses mean sea level (MSL). Thus, bathymetric depths are modified by accounting for the difference between MLLW to MSL. The datum information is obtained from the National Oceanic and Atmospheric Administration (NOAA) Tides and Currents ${ }^{2}$. The difference between MLLW to MSL is $1.43 \mathrm{~m}$ for the outlet to the Cape Cod Bay and $0.55 \mathrm{~m}$ for the outlet to the Buzzards Bay. Thus, a linear variation from $0.55 \mathrm{~m}$ to $1.43 \mathrm{~m}$ along the canal is applied to the bathymetry.

The east and the west boundaries of the numerical grid are intentionally selected to be close to the water level stations. Harmonic constituents from these two stations are extracted from the NOAA Tides and Currents ${ }^{2}$ and applied to the corresponding boundary of the grid as the ROMS tidal forcing. Tidal components include M2, S2, N2, K2, K1, O1, Q1, M4 and M6. Due to the lack of tidal current station close to the west boundary, there is no applicable tidal current harmonics in the ROMS tidal forcing. Overall, ROMS is configured to simulate the tidal flows for 32 days, encompassing an entire lunar cycle. Simulation results for the first 2 days are neglected to eliminate the spin up effect of the model. The resolution of the numerical grid is approximately $15 \mathrm{~m}$. 


\section{C.2. Model Verification - Camp Edwards}

The simulation results are validated by computing the tidal constituents using harmonic analysis and comparing these with the records from current stations and water level stations obtained from NOAA Tides and Currents ${ }^{2}$. In the modeling region, there are 3 current stations, Station COD0901, Station COD0902 and Station COD0903 as well as 5 water level stations available, Station 8447180, Station 8447173, Station 8447191, Station 8447259 and Station 8447270. Locations of each station are mapped in Figure C-4.

a)

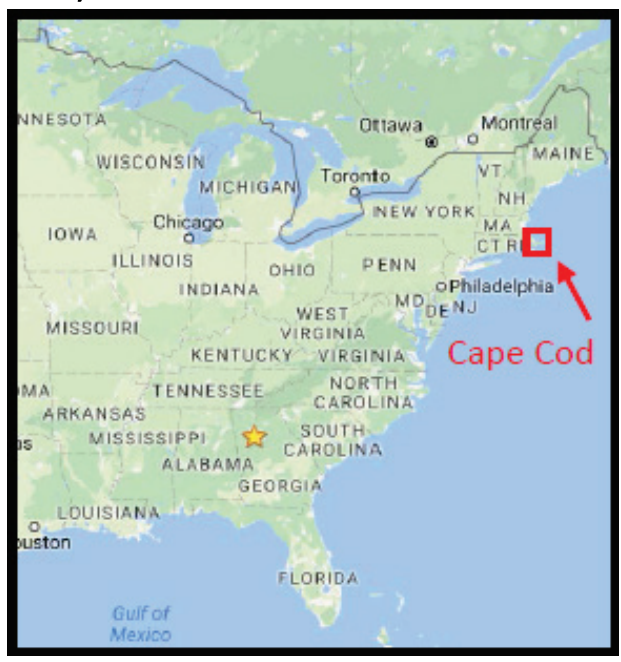

b)

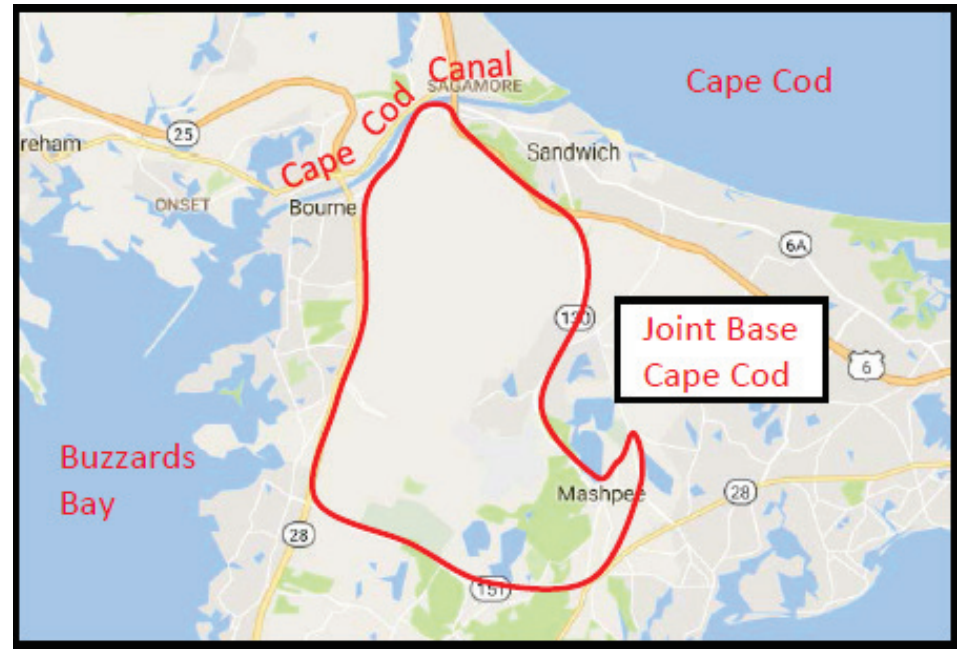

Figure C-2. Maps of areas of interest highlighted in red: (a) Cape Cod in the scope of the U.S. east coast (b) Camp Edwards, Massachusetts

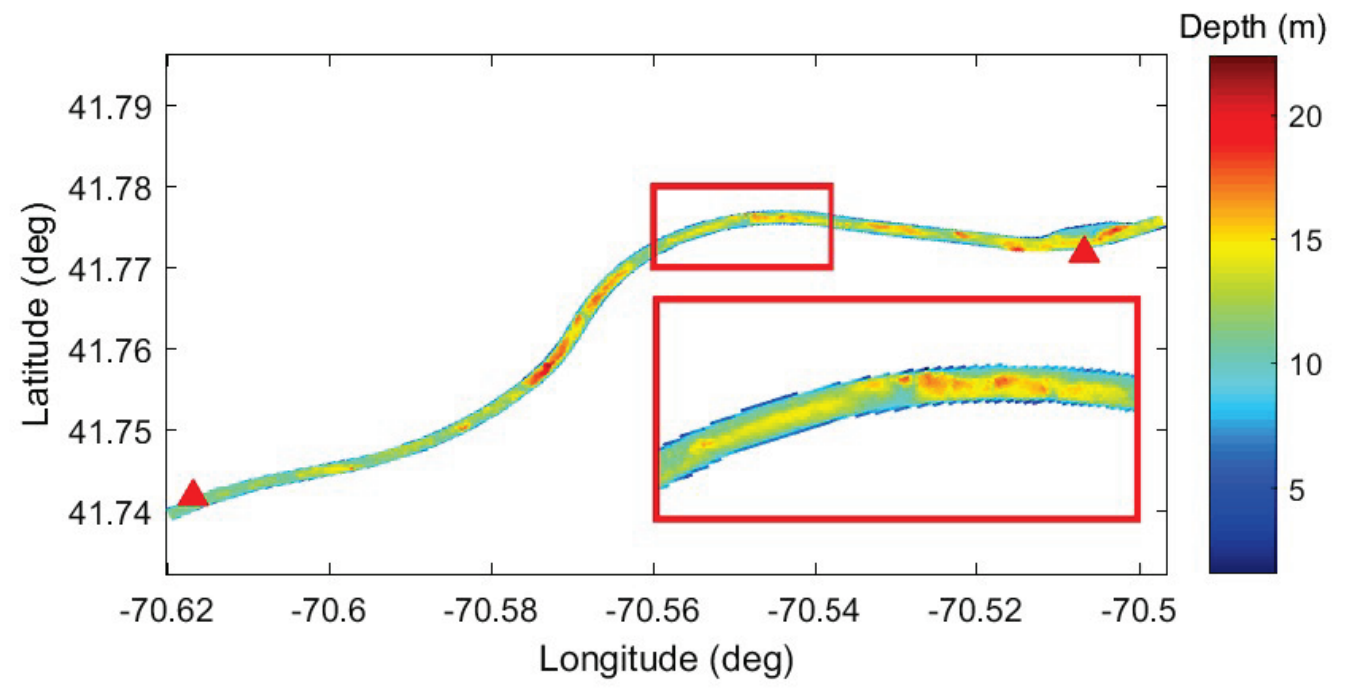

Figure C-3. Model bathymetry of the Cape Cod Canal. Zoom-in view enlarges the region adjacent to Camp Edwards. Triangles mark the locations of water level stations used for tidal forcing in ROMS.

Following the method of Defne et al. (2012), parameters are calculated to estimate the extent of model over-prediction or under-prediction of the tidal harmonic constituents, including amplitude difference (amd), percentage of amplitude difference (amdp) and phase difference (phd), defined as,

$$
a m d_{k}=\left(a m p_{m}\right)_{k}-\left(a m p_{o}\right)_{k},
$$




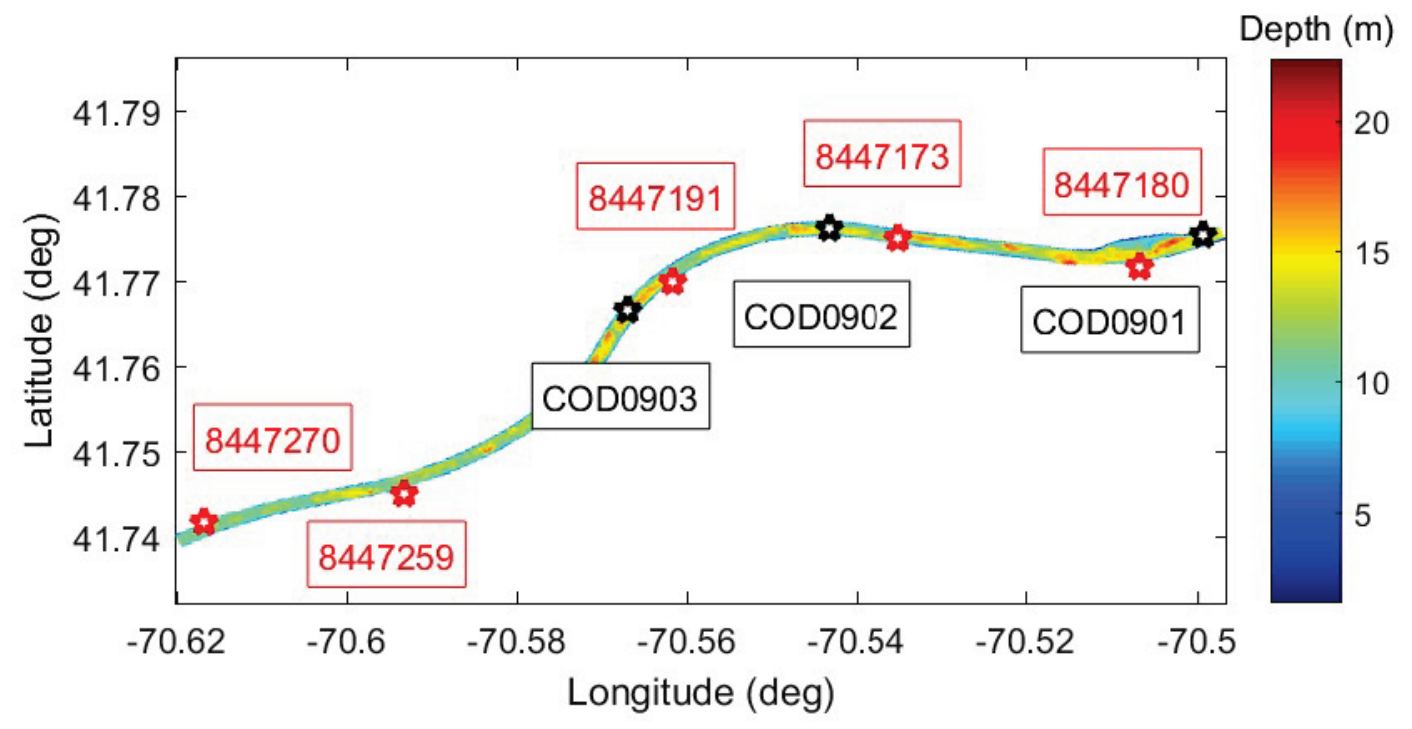

Figure C-4. Model bathymetry of the Cape Cod Canal. Red stars red mark locations of tidal harmonic data. Black stars mark locations of current stations.

$$
\begin{aligned}
& a m d p_{k}=\frac{\left(a m p_{m}\right)_{k}-\left(a m p_{o}\right)_{k}}{\left(a m p_{o}\right)_{k}} \times 100, \\
& \text { phd } d_{k}=\left(p h a_{m}\right)_{k}-\left(p h a_{0}\right)_{k},
\end{aligned}
$$

in which $(a m p)_{k}$ and $(p h a)_{k}$ mean the amplitude and the phase of the kth harmonic constituent, respectively. Subscript $m$ and $o$ represent calculation from the model output and the observational data, respectively. For current stations, $(\mathrm{amp})_{k}$ is calculated as,

$$
(a m p)_{k}=\sqrt{\left(a_{m a j}^{2}\right)_{k}+\left(a_{\min }^{2}\right)_{k^{\prime}}}
$$

Where $a_{m a j}$ and $a_{\min }$ are the major and the minor axis amplitudes of the tidal ellipse. Also, another parameter called the tidal ellipse inclination difference (incd) is calculated between the current stations and the same locations of model output, defined as,

$$
\text { incd } \left.d_{k}=(\text { inc })_{m}-(\text { inc })_{0}\right)_{k},
$$

in which (inc) $k$ is the orientation of the tidal ellipse of the $k$ th harmonic constituent (measured in degrees, anti-clockwise from East to the semi-major axis of a tidal ellipse).

Verifications for each water level and tidal currents stations are listed from Tables C-1 to 8. In general, the model simulation results of tidal harmonic constituents are consistent with the observation records with errors for the major constituents generally under 10\%. Most importantly, the phase is reproduced accurately. Differences in tidal current harmonics are slightly larger, presumably caused by the lack of tidal current harmonics in the tidal forcing for ROMS. 
Table C-1. Verification of tidal water level harmonic constituents for Station $8447180(-70.5067,41.7717)$

\begin{tabular}{|c|c|c|c|c|c|}
\hline $\mathbf{8 4 4 7 1 8 0 ~ ( - 7 0 . 5 0 6 7 , ~ 4 1 . 7 7 1 7 ) ~}$ & \multicolumn{3}{|c|}{} \\
\hline Constituent & Period & amp & amd & amdp & phd \\
\hline & (hrs) & $(\mathrm{m})$ & $(\mathrm{m})$ & $(\%)$ & (min) \\
\hline M2 & 12.4206 & 1.251 & -0.05 & -4 & -2 \\
\hline N2 & 12.65835 & 0.294 & -0.01 & -4 & -2 \\
\hline S2 & 12 & 0.184 & -0.03 & -15 & 32 \\
\hline K1 & 23.93447 & 0.136 & 0 & -2 & 0 \\
\hline O1 & 25.81934 & 0.111 & 0 & -2 & 4 \\
\hline M6 & 4.1402 & 0.04 & 0 & -11 & 4 \\
\hline M4 & 6.2103 & 0.029 & -0.01 & -24 & -30 \\
\hline Q1 & 26.86836 & 0.021 & 0 & 1 & 4 \\
\hline
\end{tabular}

Table C-2. Verification of tidal water level harmonic constituents for Station $8447173(-70.535,41.775)$

\begin{tabular}{|c|c|c|c|c|c|}
\hline 8447173 (-70.535, 41.775) & \multicolumn{3}{|c|}{} \\
\hline Constituent & Period & amp & amd & amdp & phd \\
\hline & (hrs) & $(\mathrm{m})$ & $(\mathrm{m})$ & $(\%)$ & (min) \\
\hline M2 & 12.4206 & 1.115 & -0.06 & -5 & -4 \\
\hline N2 & 12.65835 & 0.267 & -0.01 & -5 & -4 \\
\hline S2 & 12 & 0.165 & -0.03 & -19 & 32 \\
\hline K1 & 23.93447 & 0.131 & -0.01 & -5 & -4 \\
\hline O1 & 25.81934 & 0.105 & 0 & -2 & 4 \\
\hline M4 & 6.2103 & 0.044 & 0 & -3 & -1 \\
\hline M6 & 4.1402 & 0.039 & -0.01 & -14 & 1 \\
\hline Q1 & 26.86836 & 0.02 & 0 & 0 & 0 \\
\hline
\end{tabular}

Table C-3. Verification of tidal water level harmonic constituents for Station $8447191(-70.5617,41.77)$

\begin{tabular}{|c|c|c|c|c|c|}
\hline \multicolumn{6}{|c|}{$8447191(-70.5617,41.77)$} \\
\hline Constituent & Period & amp & amd & amdp & phd \\
\hline & (hrs) & $(\mathrm{m})$ & $(\mathrm{m})$ & $(\%)$ & (min) \\
\hline M2 & 12.4206 & 0.861 & 0 & 0 & 2 \\
\hline N2 & 12.65835 & 0.217 & 0 & -2 & 0 \\
\hline S2 & 12 & 0.124 & -0.02 & -15 & 30 \\
\hline K1 & 23.93447 & 0.104 & 0.01 & 7 & 0 \\
\hline 01 & 25.81934 & 0.092 & 0 & 2 & -17 \\
\hline M4 & 6.2103 & 0.044 & 0.01 & 15 & 5 \\
\hline M6 & 4.1402 & 0.034 & 0 & -14 & 2 \\
\hline Q1 & 26.86836 & 0.018 & 0 & 4 & -45 \\
\hline
\end{tabular}


Table C-4. Verification of tidal water level harmonic constituents for Station $8447259(-70.5933,41.745)$

\begin{tabular}{|c|c|c|c|c|c|}
\hline $\mathbf{8 4 4 7 2 5 9}(-\mathbf{7 0 . 5 9 3 3} \mathbf{4 1 . 7 4 5})$ & \multicolumn{3}{|c|}{} \\
\hline Constituent & Period & amp & amd & amdp & phd \\
\hline M2 & (hrs) & $(\mathrm{m})$ & $(\mathrm{m})$ & $(\%)$ & (min) \\
\hline N2 & 12.4206 & 0.595 & 0.02 & 3 & 0 \\
\hline K1 & 12.65835 & 0.168 & 0 & -1 & 2 \\
\hline S2 & 23.93447 & 0.091 & 0 & 3 & 20 \\
\hline O1 & 12 & 0.09 & -0.01 & -10 & 20 \\
\hline M4 & 25.81934 & 0.085 & 0 & -4 & -13 \\
\hline M6 & 6.2103 & 0.068 & 0 & -3 & -6 \\
\hline Q1 & 4.1402 & 0.033 & -0.01 & -28 & 4 \\
\hline & 26.86836 & 0.016 & 0 & 6 & -76 \\
\hline
\end{tabular}

Table C-5. Verification of tidal water level harmonic constituents for Station 8447270 (-70.6167, 41.7417)

\begin{tabular}{|c|c|c|c|c|c|}
\hline $\mathbf{8 4 4 7 2 7 0}(-\mathbf{7 0 . 6 1 6 7 , ~ 4 1 . 7 4 1 7 )}$ & \multicolumn{3}{|c|}{} & phd \\
\hline Constituent & Period & amp & amd & amdp & (min) \\
\hline M2 & (hrs) & $(\mathrm{m})$ & $(\mathrm{m})$ & $(\%)$ & 17 \\
\hline N2 & 12.4206 & 0.517 & 0.01 & 1 & 13 \\
\hline S2 & 12.65835 & 0.145 & 0 & 1 & 48 \\
\hline M4 & 12 & 0.096 & -0.01 & -13 & -10 \\
\hline K1 & 6.2103 & 0.091 & -0.02 & -17 & 12 \\
\hline SO1 & 23.93447 & 0.081 & 0 & 3 & 0 \\
\hline M6 & 25.81934 & 0.07 & 0 & 4 & 8 \\
\hline Q1 & 4.1402 & 0.021 & 0 & 1 & 0 \\
\hline
\end{tabular}

Table C-6. Verification of tidal current harmonic constituents for Station COD0901 (-70.4993, 41.77553)

\begin{tabular}{|c|c|c|c|c|c|c|c|}
\hline \multicolumn{8}{|c|}{ COD0901 (-70.4993, 41.77553) } \\
\hline Constituent & Period & amp & Amd & amdp & inc & incd & phd \\
\hline & (hrs) & $(\mathrm{m} / \mathrm{s})$ & $(\mathrm{m} / \mathrm{s})$ & $(\%)$ & (deg) & (deg) & (min) \\
\hline M2 & 12.4206 & 1.54 & -0.08 & -5 & 38 & -15 & 8 \\
\hline N2 & 12.6583 & 0.31 & -0.07 & -22 & 37 & -14 & -6 \\
\hline M6 & 4.1402 & 0.17 & 0.01 & 5 & 35 & -13 & 9 \\
\hline S2 & 12 & 0.16 & 0.03 & 17 & 37 & -14 & 12 \\
\hline K1 & 23.9345 & 0.09 & -0.02 & -27 & 39 & -17 & -8 \\
\hline M4 & 6.2103 & 0.06 & 0.04 & 76 & 41 & -17 & 35 \\
\hline 01 & 25.8193 & 0.05 & -0.01 & -20 & 37 & -14 & 34 \\
\hline Q1 & 26.8684 & 0.01 & 0 & 20 & 40 & -20 & 318 \\
\hline
\end{tabular}


Table C-7. Verification of tidal current harmonic constituents for Station COD0902 (-70.5433, 41.77617)

\begin{tabular}{|c|c|c|c|c|c|c|c|}
\hline \multicolumn{8}{|c|}{ COD0902 (-70.5433, 41.77617) } \\
\hline \multirow{2}{*}{ Constituent } & Period & amp & amd & amdp & inc & incd & phd \\
\hline & (hrs) & $(\mathrm{m} / \mathrm{s})$ & $(\mathrm{m} / \mathrm{s})$ & (\%) & (deg) & (deg) & $(\min )$ \\
\hline M2 & 12.4206 & 1.69 & 0.19 & 11 & 10 & -13 & 12 \\
\hline N2 & 12.6583 & 0.37 & -0.05 & -15 & 8 & -11 & -4 \\
\hline S2 & 12 & 0.18 & 0.06 & 30 & 17 & -19 & 14 \\
\hline M6 & 4.1402 & 0.17 & 0.03 & 17 & 11 & -14 & 32 \\
\hline K1 & 23.9345 & 0.1 & -0.01 & -9 & 7 & -10 & 32 \\
\hline M4 & 6.2103 & 0.06 & 0.04 & 68 & 14 & -15 & -20 \\
\hline 01 & 25.8193 & 0.05 & 0 & 3 & 16 & -19 & 34 \\
\hline Q1 & 26.8684 & 0.01 & 0 & -23 & 178 & -7 & 193 \\
\hline
\end{tabular}

Table C-8. Verification of tidal current harmonic constituents for Station COD0903 (-70.567, 41.76654)

\begin{tabular}{|c|c|c|c|c|c|c|c|}
\hline \multicolumn{8}{|c|}{ COD0903 $(-70.567,41.76654)$} \\
\hline \multicolumn{8}{|c|}{$\begin{array}{cc}\text { CoD0903 }(-/ 0.56 /, 41 . / 6654) \\
\text { Constituent } & \text { Period }\end{array}$} \\
\hline & (hrs) & $(\mathrm{m} / \mathrm{s})$ & $(\mathrm{m} / \mathrm{s})$ & (\%) & (deg) & (deg) & (min) \\
\hline M2 & 12.4206 & 1.67 & 0.11 & 5 & 53 & 6 & 10 \\
\hline N2 & 12.6583 & 0.37 & -0.07 & -19 & 53 & 7 & 2 \\
\hline S2 & 12 & 0.17 & 0.05 & 31 & 54 & 6 & -10 \\
\hline M6 & 4.1402 & 0.16 & 0.03 & 20 & 52 & 8 & 12 \\
\hline M4 & 6.2103 & 0.09 & 0.02 & 28 & 50 & 8 & 18 \\
\hline K1 & 23.9345 & 0.09 & -0.01 & -13 & 53 & 6 & -40 \\
\hline 01 & 25.8193 & 0.05 & 0 & 3 & 54 & 5 & 13 \\
\hline Q1 & 26.8684 & 0.01 & 0 & -42 & 55 & 7 & 206 \\
\hline
\end{tabular}

\section{C.3. Tidal Energy Assessment - Camp Edwards}

For the resource assessment based on the model simulation data, we follow the guidelines from the International Electrotechnical Commission (IEC) Technical Specification for tidal energy resource assessments. $^{4}$

The spatial variation of the depth-averaged current speed is shown in Figure C- 5, whereas the maximum depth-averaged current speed is shown in Figure C-6. The enlarged view of the (maximum) depth-averaged current speed has the same geographic range as Figure C-2. As shown in Figure C-5, the depth- averaged currents close to the Buzzards Bay are generally larger than currents close to the Cape Cod Bay, which could be attributed to the broadened channel close to the Cape Cod Bay. Currents slowdown in the broadened channel in order to satisfy mass conservation. The maximum depth averaged currents in Figure C-6 show a similar pattern but with almost a double magnitude compared with the mean depth- averaged currents in Figure C-5.

The tidal constituents are computed from the month-long model simulation velocity data, and these constituents are used to compute a full-year time series of the velocity with 10-minute temporal resolution. 


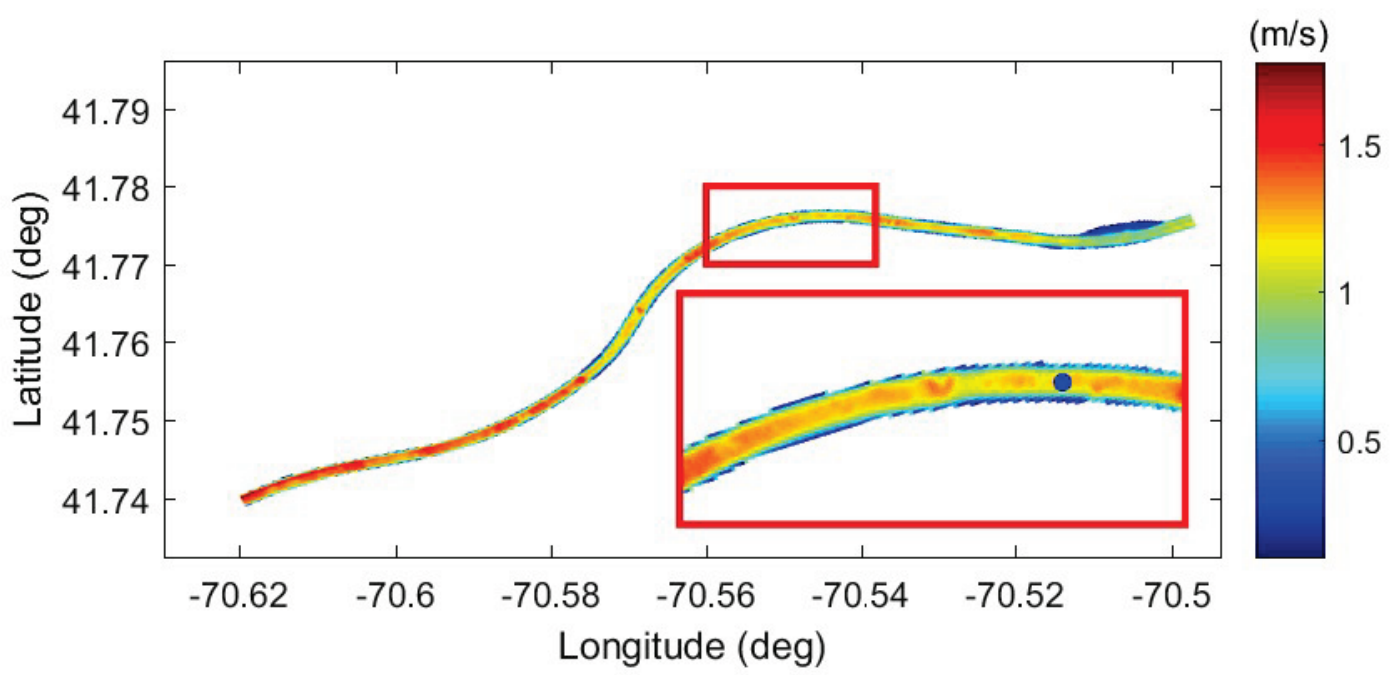

Figure C-5. Depth-averaged current speed. Zoom-in view shows the depth-averaged current speed for the region adjacent to Camp Edwards. The blue dot marks the location of Station COD0902 for evaluating AEP density.

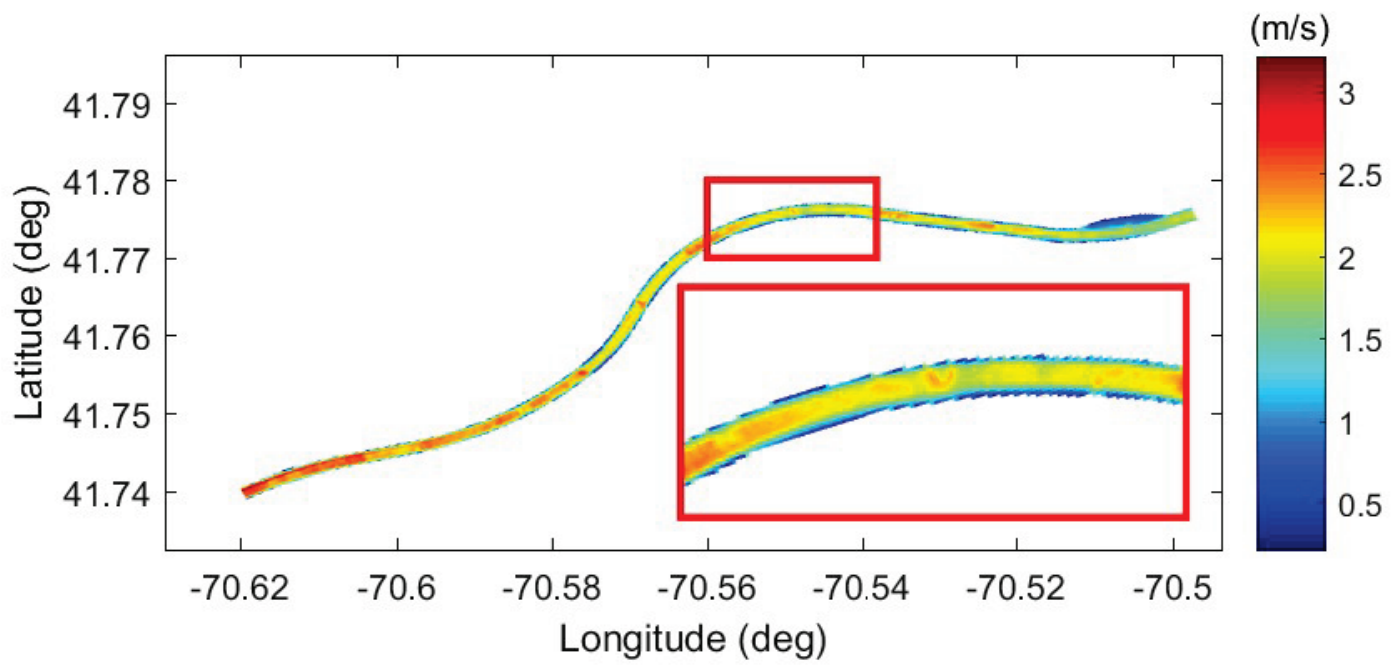

Figure C-6. Maximum depth-averaged current speed. Zoom-in view shows the maximum depthaveraged current speed for the region adjacent to Camp Edwards

These new time series data are used to develop the probability distribution of the velocity based on the method of bins $(10 \mathrm{~cm} / \mathrm{s}$ bins $) .{ }^{4}$ As marked in Figure C-4, the location of Station COD0902 is selected for assessing power density and AEP density. The histogram of depth-averaged current velocity magnitudes for that location is shown in Figure C-7, demonstrating that a velocity magnitude of $1.5 \mathrm{~m} / \mathrm{s}$ is the most common in a year.

From the joint direction and magnitude probability distributions shown in Figure C-8, it is seen that the major currents at Station COD0902 are directed close to the east and west directions, although flood and ebb are not symmetric. The exceedance curves for the two locations are shown in Figure C-9. Based on the minimum cut-in speed associated with a particular turbine, the exceedance curve identifies the proportion of time that turbine could operate. 


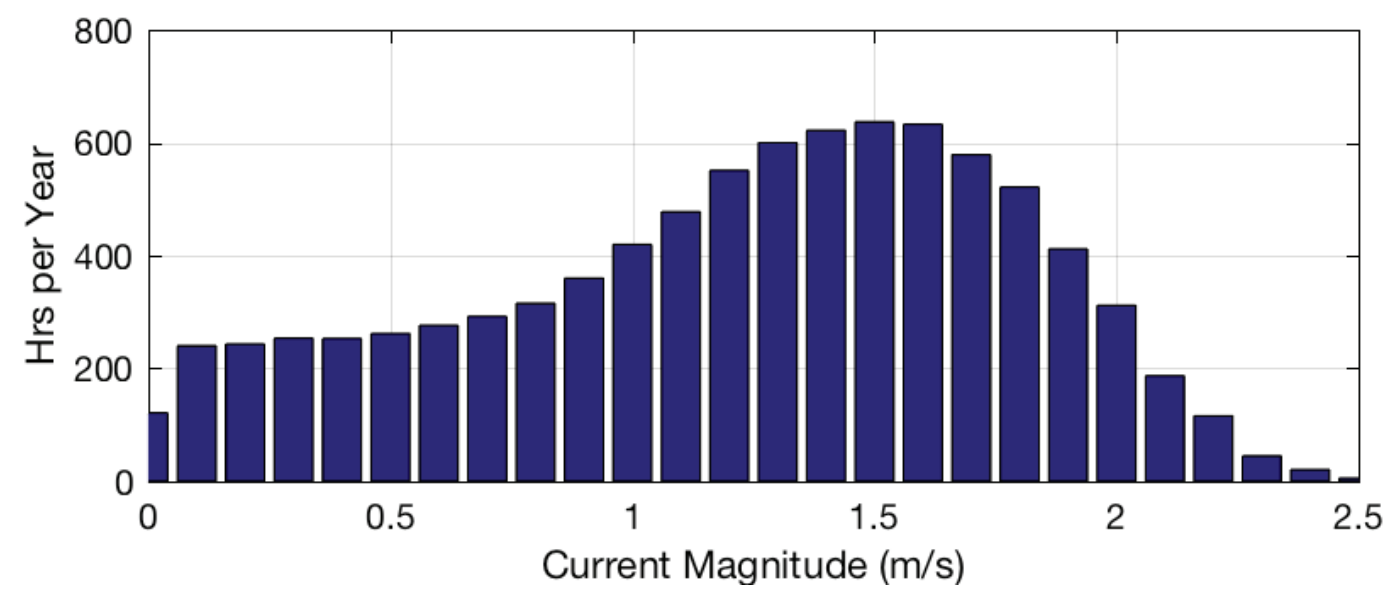

Figure C-7. Histogram of depth-averaged current velocity magnitudes for Station COD0902

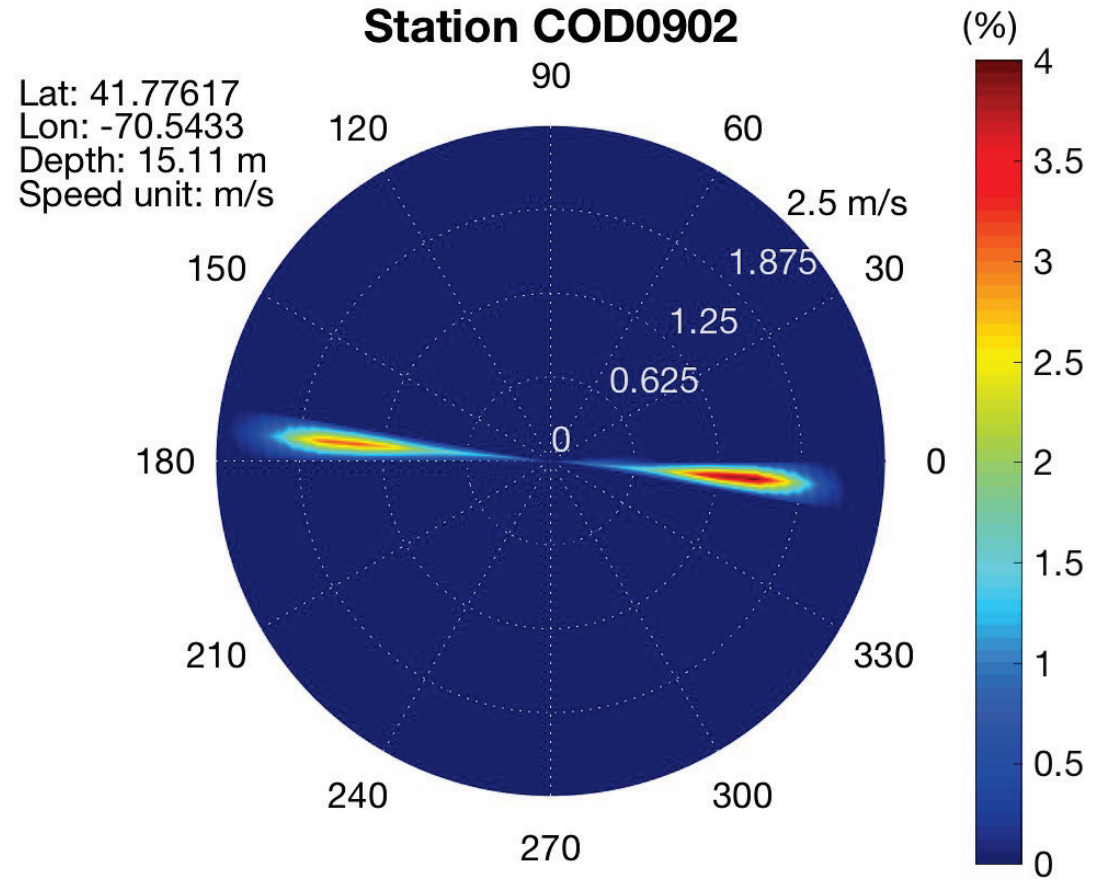

Figure C-8. Joint probability distribution of velocity and direction for Station COD0902 


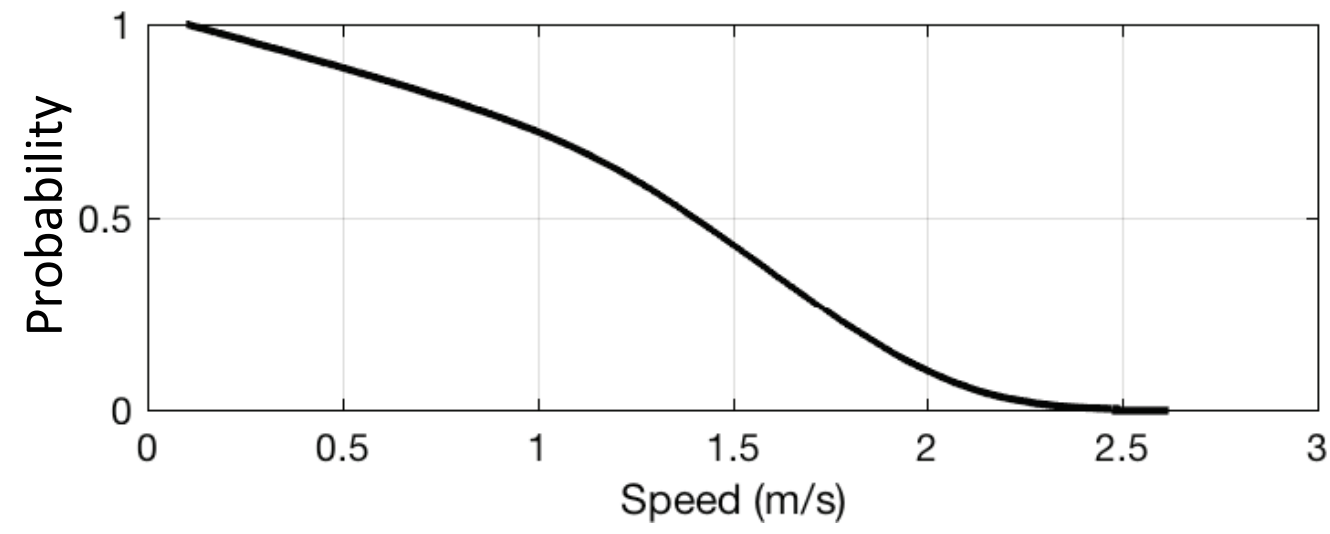

Figure C-9. Exceedance curve for current speed at Station COD0902

The available tidal energy density (energy per unit cross-sectional area) is computed for each velocity bin from the probability distribution as,

$$
P_{k}=\frac{1}{2} \rho\left|V_{k}\right|^{3},
$$

In which $\rho$ is the seawater density taken as a constant at $15^{\circ} \mathrm{C}$ and 35 PPT salinity $(\rho=1025$ $\left.\mathrm{kg} / \mathrm{m}^{3}\right) . V_{k}$ is the depth-average current speed for bin $\mathrm{k}$.

The IEC guidelines provide a methodology for computing the annual energy production (AEP) using the velocity distribution together with a power curve for the turbine. Here, because we are not using a particular turbine, we use the same methodology to calculate the annual available energy (AAE) density, which quantifies how much energy in the flow field is available per unit cross-sectional area,

$$
A A E=N_{h} \cdot \sum_{k=1}^{N_{B}} P_{k} \cdot f_{k}
$$

in which $N_{h}$ is the number of hours in the simulated year. $f_{k}$ is the probability density function (PDF) from the method of bins to group the depth-averaged current speed. $N_{B}$ is the total number of bins. The AAE density oat Station COD0902 is equal to $13.1 \mathrm{MHh} / \mathrm{m}^{2}$ and the average power density is $1.5 \mathrm{~kW} / \mathrm{m}^{2}$.

\section{C.4 Summary - Camp Edwards}

This study investigates the flow details of tidal currents and the tidal energy availability near the Joint Base Cape Cod, Massachusetts. The assessment is accomplished through the COAWST modeling system ${ }^{1}$ using a high-resolution single grid to simulate tidal flows for 32 days, encompassing an entire lunar cycle, forced by tidal constituents directly from NOAA observations. Simulation results are validated by computing tidal constituents with harmonic analysis and comparing with NOAA observations. Depth-averaged currents are relatively strong along the channel, demonstrating the need for assessing tidal flows for their energy potential. Following the guidelines from IEC Technical Specification for tidal energy resource assessment, tidal constituents from the month-long model simulation are used to compute a full year time series of current velocities. The velocity probability distributions and the AAE density is determined to be 13.1 $\mathrm{MWh} / \mathrm{m}^{2}$ at Station COD0902, a location next to the military base. 
The average power density at Station COD0902 is $1.5 \mathrm{KW} / \mathrm{m}^{2}$. This represents the amount of energy that is available for conversion to electricity at this particular location and can be converted to the available energy for a particular device by multiplying it by the device rotor swept area. It is important to note, however, that the actual electricity generated (AEP) would be some fraction of this amount once the turbine and transmission efficiencies are taken into account. In addition, if a relatively large number of devices are to be deployed, then the model simulations would need to be redone, including the extra dissipation due to energy extraction.

\section{References}

${ }^{1}$ J. C. Warner, B. Armstrong, R. Y. He, and J. B. Zambon, "Development of a coupled oceanatmosphere- wave-sediment transport (COAWST) modeling system," Ocean Modelling. 35(3), 230-244 (2010).

${ }^{2}$ Tides and Currents Products. National Oceanic and Atmospheric Administration. https://tidesandcurr- ents.noaa.gov/products.html [accessed 2016].

${ }^{3}$ Z. Defne, K. A. Haas, H. M. Fritz, L. Jiang, S. P. French, X. Shi, B. T. Smith, V. S. Neary and K. M. Stewart "National geodatabase of tidal stream power resource in USA," Renewable and Sustainable Energy Reviews. 16, 3326-3338 (2012).

${ }^{4}$ Marine energy-Wave tidal and other water current converters-Part 201: Tidal energy resource assessment and characterization. International Electrotechnical Commission Technical Specification (2015). 


\section{Appendix D. Tidal Power Primer}

\section{D.1. Tidal Resource Assessment}

The tides are caused by the gravitational pulls on Earth by both the moon and the sun, with the moon's gravitational effect, due to its close proximity to Earth, being the primary driver of Earth's tides and the sun's gravitational pull being a secondary driver. The lunar orbital period is 24 hours and 50 minutes, while Earth's rotational period, 24 hours, dictates the timing of the sun's tidal effects. The availability of peak tidal power occurs twice each day but is 50 minutes later each day. This effect can best be explained through several diagrams. The vectors on Earth's surface, shown in Figure D-1, represent the difference in the gravitational force the moon exerts at a given point on the surface versus the force it would exert at the center of the Earth. The resultant force vectors visually represent what happens to the water: in the Earth-moon plane (left-to-right as shown), the water is attracted to the moon causing the waters to "bulge" (i.e., high tide) towards the moon. Concurrently, a similar effect is seen on the opposite side. The net impact on the top and bottom of the sphere is the waters moving away resulting in low tide.

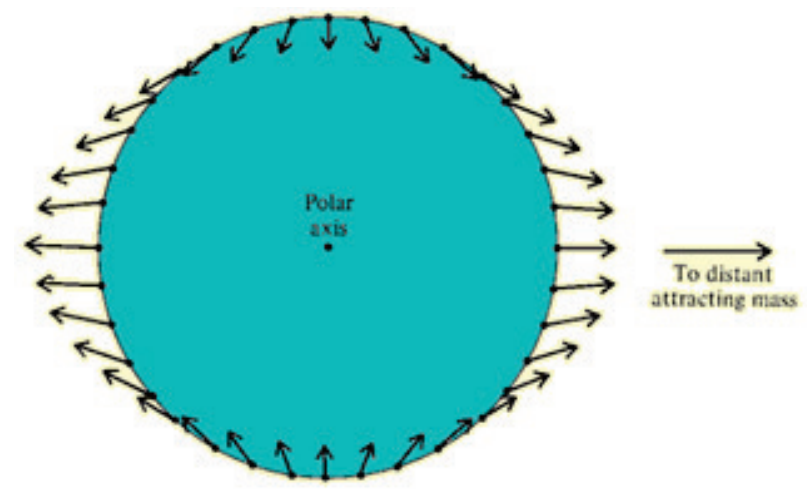

Figure D-1. Tide-generating forces based on Earth-moon interactions ${ }^{38}$

The axis on which Earth rotates, relative to Earth's orbital plane as it revolves around the sun, is tilted approximately $23^{\circ}$. This tilt angle is known as the declination angle. There is a comparable declination angle when describing Earth's axis of rotation relative to the moon's orbital plane. This positional relationship, as shown in Figure D-2, results in the wide range of tidal effects experienced around the globe. Areas near the equator experience semi-diurnal tides (i.e., two high and two low tides per day designated by the red labels and blue labels $\mathrm{H} 1$ and $\mathrm{H} 2$, respectively), while high latitudes experience diurnal tides (shown as by the green $\mathrm{L}$ and $\mathrm{H}$ ). Mid-latitude regions experience mixed diurnal tides - two tides per day — but with significant diurnal inequality between successive high and low tides.

\footnotetext{
${ }^{38}$ Hagerman, G.; Polagye, B. "Methodology for Estimating Tidal Current Energy Resources and Power Production by Tidal In-Stream Energy Conversion (TISEC) Devices,” EPRI, 2006.
} 


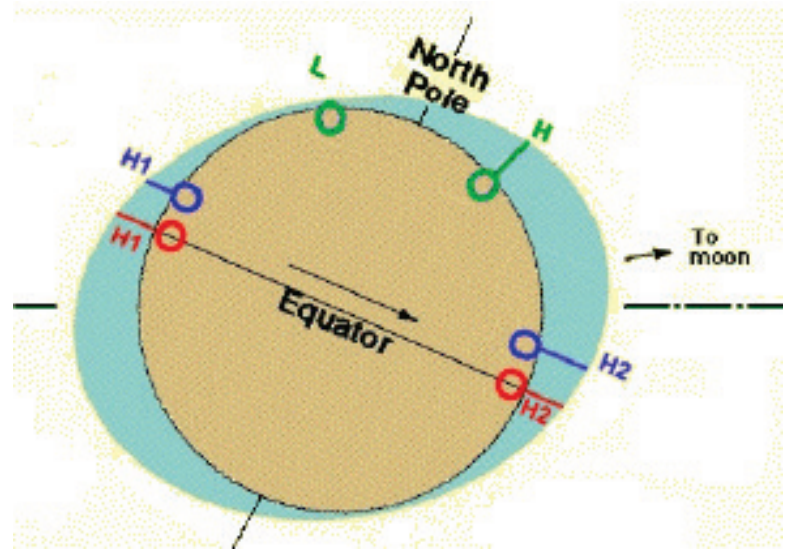

Figure D-2. Influence of the moon's declination on tidal forces ${ }^{39}$

The periodic nature and variances of the semi-diurnal, mixed, and diurnal tides can be seen in Figure D-3. The period of the lunar tides is roughly 12 hours and 25 minutes, and they are semidiurnal, occurring twice each day (or, more precisely, every 24 hours and 50 minutes). The influence of the moon on the tides changes as the moon's declination progresses from its extreme position over the north tropics to a position over the south tropics in 14 days, with the strongest tidal pulls from the moon at these extremes. In between, when the moon is over the equator, the diurnal inequality of the tides is minimized, as occurs twice per tropical month (every 27.3 days).

Semidiurnal Tide

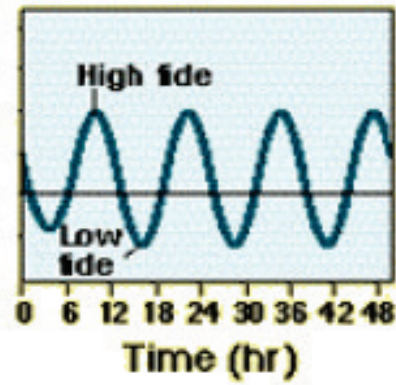

Mixed Tide

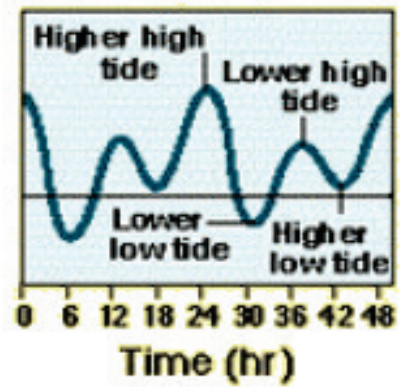

Diurnal Tide

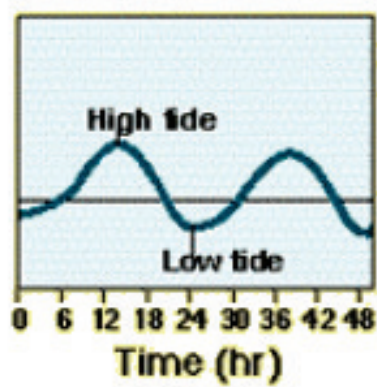

Figure D-3. Graphical depiction of tidal patterns ${ }^{40}$

Just as the moon's gravitational pull causes a tidal bulge (i.e., rising of water levels), the sun's gravitational pull also causes a tidal bulge, but its amplitude is only $46 \%$ as high as the lunar bulge. ${ }^{41}$ In the absence of the moon, the solar tides would be very periodic or diurnal, occurring every 12 hours. Additionally, the solar tidal bulge would always face the sun; in other words, it would be the same time every day with high tide at solar noon and corresponding high tide on the opposite side of the earth at solar midnight.

Figure D-4 illustrates the varying influence of the moon and sun on Earth's tides. The light royal blue oval represents the lunar bulge and the turquoise oval represents the solar bulge. When the moon and the sun are pulling in the same direction (first Earth diagram on the left in Figure D-4), it

\footnotetext{
${ }^{39}$ Hagerman, G.; Polagye, B. "Methodology for Estimating Tidal Current Energy Resources and Power Production by Tidal In-Stream Energy Conversion (TISEC) Devices," EPRI, 2006.

${ }^{40}$ Ibid.

${ }^{41}$ Ibid.
} 
causes the highest high tide, known as the spring tide. In the next phase (shown as third quarter), the moon and sun are pulling in different directions $90^{\circ}$ apart. This results in lower high tides and higher low tides. This phenomenon is known as the neap tide, and it occurs during both the first and third quarters of the moon. During the half moon, new moon, and full moon, the lunar and solar tidal bulge work in unison, resulting in a spring tide, caused by the effect described in Figure D-1.

There are other factors that affect the tides, such as wind, storms, salinity, or even spring run-off, but often the factors have smaller magnitudes and longer periods (except for storm impacts). For all practical purposes, a 29-day site-specific resource analysis yields enough information to generate a reliable tidal flow assessment enabling a usable annual tidal flow prediction.

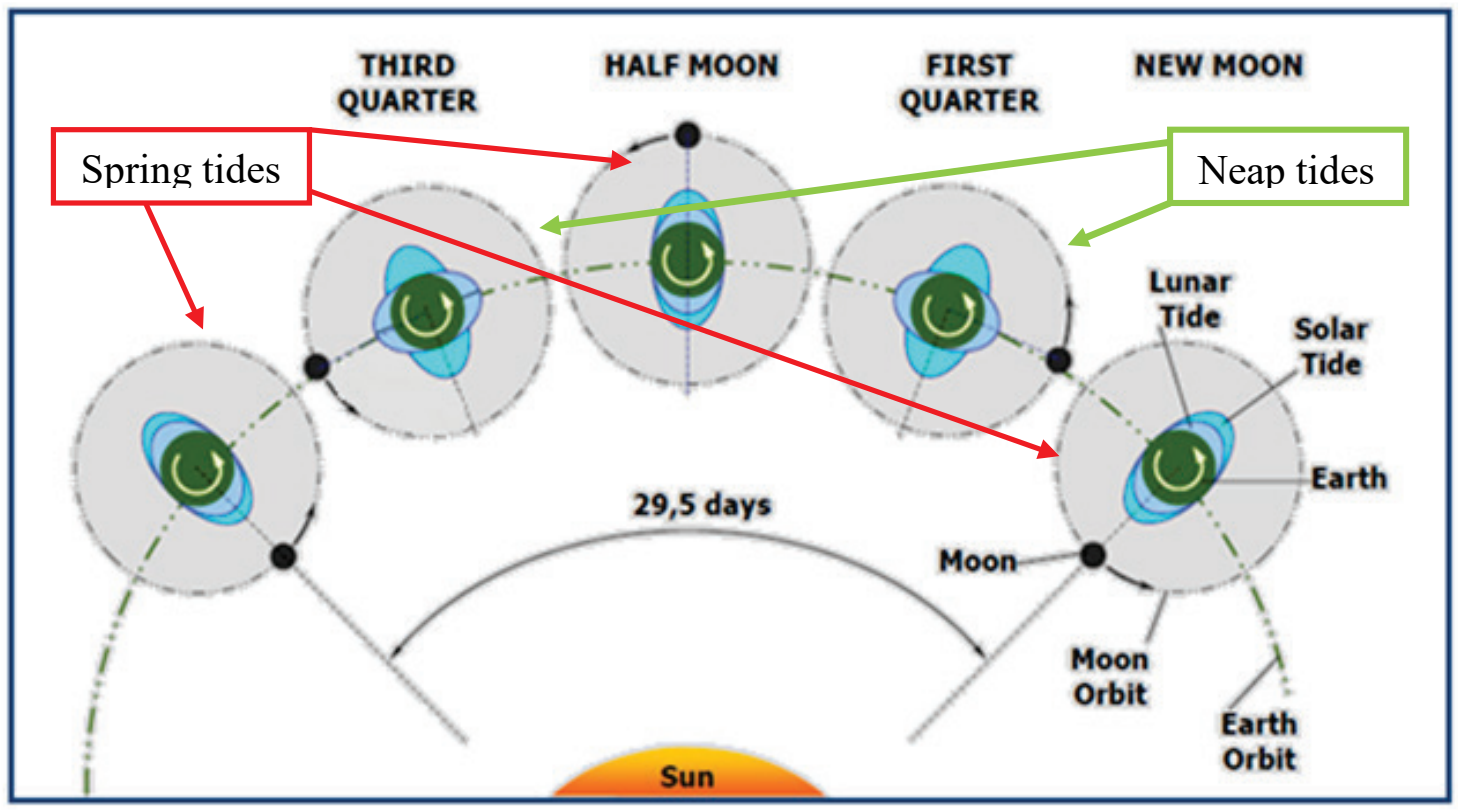

Figure D-4. Phases of the moon and resultant lunar and solar spring and neap tides ${ }^{42}$

\section{D.2. Tidal Parameters for Power Production}

The tidal current speed is a critical parameter in resource assessment; however, since it does vary significantly through the various periodic influences of the moon and sun, it is also critical to determine how many periods the tidal current is at each distinct velocity using a frequency distribution (Figure D-5) approach.

${ }^{42}$ The World Ocean Observatory, Tidal Energy, Tidal Energy Physics and Resource.

http://www.thew2o.net/events/oceanenergy/images/tidal_energy.pdf. Accessed Sept 2010. 


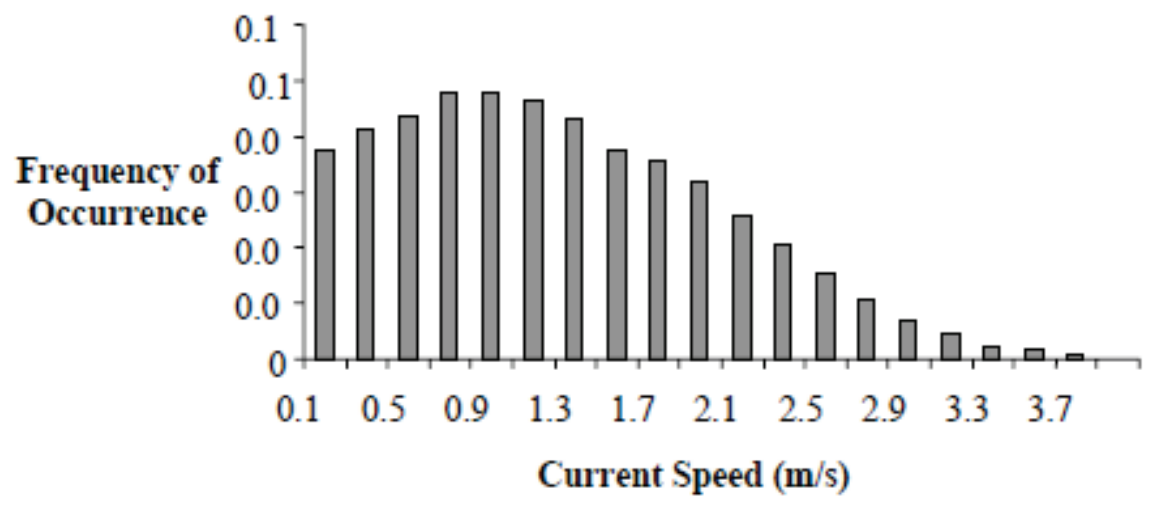

Figure D-5. Sample tidal current speed distribution ${ }^{43}$

The turbines operate in three regions: below cut-in speed, cut-in speed to rated speed, and greaterthan-rated speed in the same manner as wind turbines. This can be seen graphically in Figure D-6.

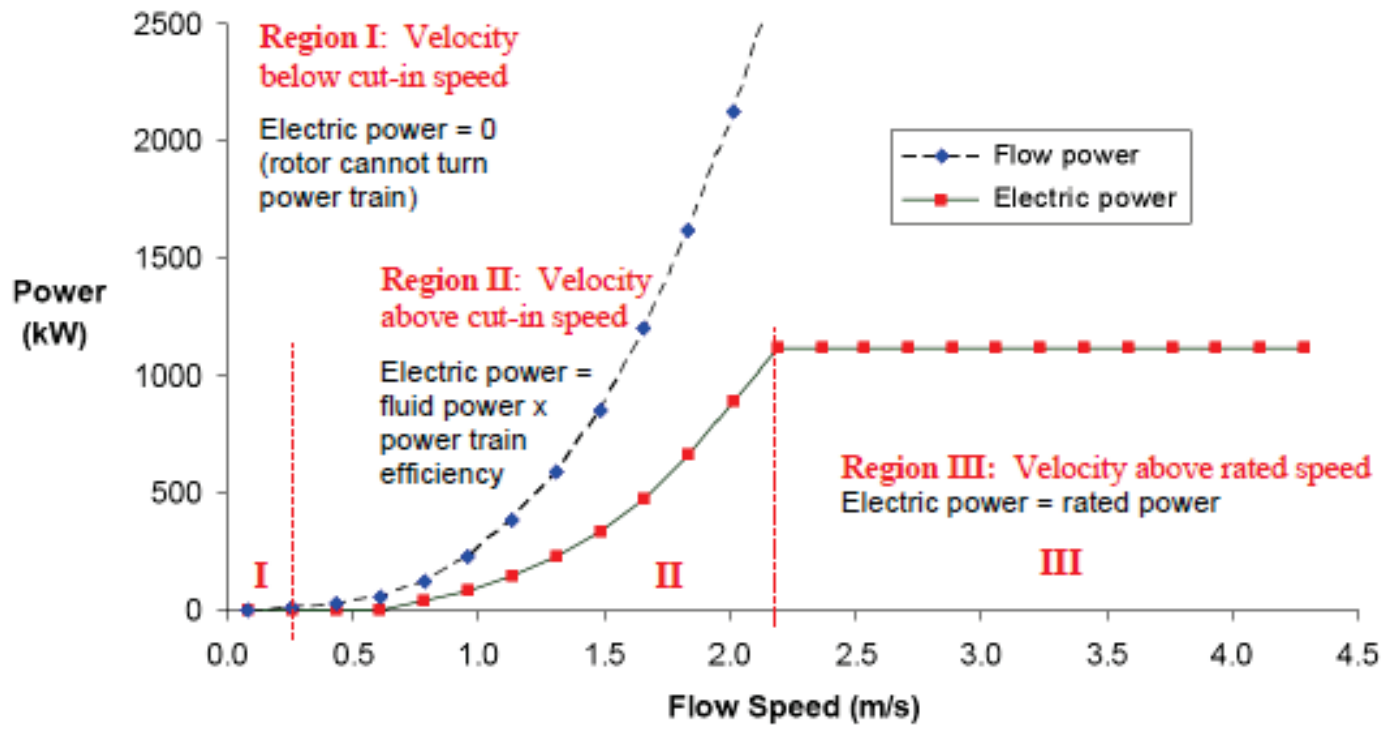

Figure D-6. Sample turbine output power versus flow speed ${ }^{44}$

\section{D.3. Bournedale Tidal Height and Period Assessment}

At an existing station, Bournedale, Cape Cod Canal, MA - Station ID: $8447191,{ }^{45}$ tides in the Cape Cod Canal are measured and reported regularly to the National Oceanic and Atmospheric Administration (NOAA) Tides \& Currents database. The data presented here are predictions of the tides, used as examples to illustrate tidal flow magnitudes and the impacts of solar tides on lunar tidal patterns.

The following two graphs (Figures D-7 and D-8) illustrate the variability in the periodic tide levels at the Bournedale station for week-long and month-long intervals. For the month-long interval, the

\footnotetext{
${ }^{43}$ Hagerman, G.; Polagye, B. "Methodology for Estimating Tidal Current Energy Resources and Power Production by Tidal In-Stream Energy Conversion (TISEC) Devices," EPRI, 2006.

${ }^{44}$ Ibid.

${ }^{45}$ National Oceanographic and Atmospheric Administration, Tides \& Currents, https://tidesandcurrents.noaa.gov/stationhome.html?id=8447191 . Accessed May, 2017.
} 
mean range $(\mathrm{MN})$ of the tides is the difference in height between the mean high-water mark and the mean low-water mark. For Bournedale, the $\mathrm{MN}$ is $1.033 \mathrm{~m}$. The diurnal range (GT) is the difference in height between the mean higher high-water mark and the mean lower low water mark. For Bournedale, the GT is $1.926 \mathrm{~m}$.

The periodic nature of tidal flow means the tidal current will reverse flow direction four times per day for ebb (towards low tide) and flood (towards high tide) cycles. For most of the day, the tides are either moving in or out. It is only during the transitional time from tide coming in versus going out, known as "slack water," that there is very little velocity current in the water. The slack water duration varies site to site, but the duration is usually in the 5-30-minute range with shorter times associated with higher tidal current velocities and vice versa. The approximate velocity of the tide is represented visually by the steepness of the sinusoidal curves in Figure D-7. The tops and bottoms of these curves are where the tidal current slows and then becomes neutral (i.e., zero current speed) as it transitions from ebb to flood or vice versa. Figure D-7 shows a fairly "normal" seven-day tidal oscillation. The graph shows the water level relative to the mean lower low water level, which serves as the baseline.

The seven-day timeframe for Figure D-7 illustrates the impact of the solar tides on the lunar tides. When the oscillations between several consecutive days (e.g., 4/20-4/23) are relatively small, it is due to the neap tide. When the oscillations are larger (e.g., 4/26-4/28), it is due to the spring tide.

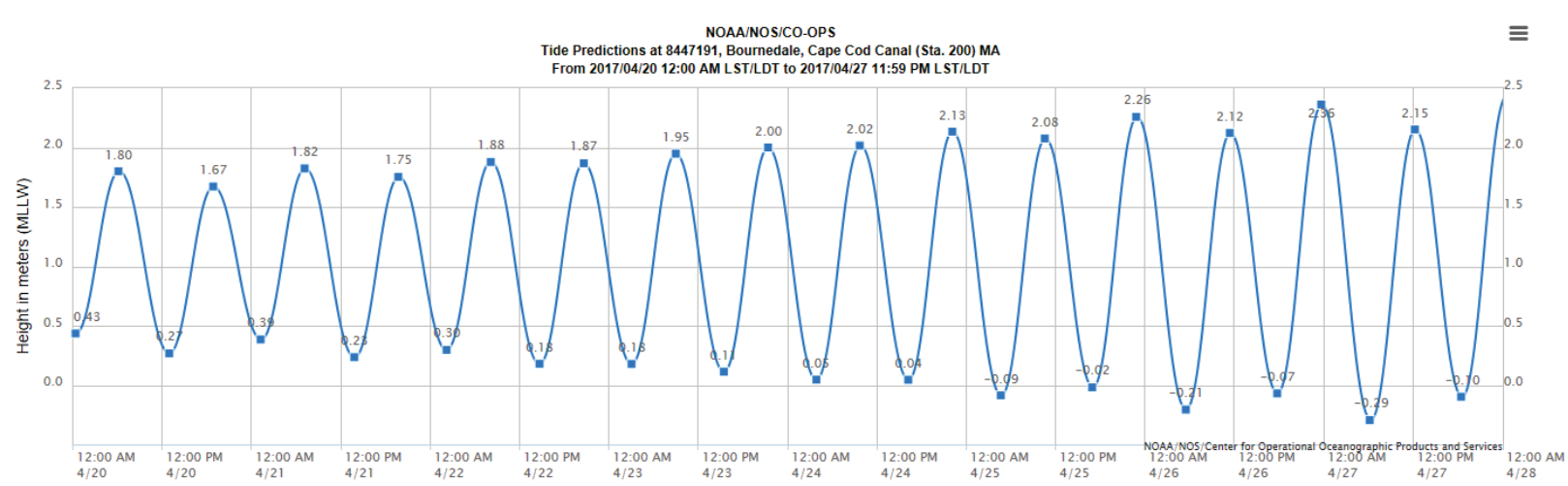

Figure D-7. Bournedale, Cape Cod Canal tide level per mean lower low water level: seven-day profile ${ }^{46}$

The 30-day profile, as shown in Figure D-8, shows great consistency in period length but considerable variation in the water height or amplitude, especially as driven by the neap and spring tides.

\footnotetext{
${ }^{46}$ National Oceanographic and Atmospheric Administration, Tides \& Currents, http://tidesandcurrents.noaa.gov/noaatidepredictions/viewDailyPredictions.jsp?Stationid=8447191. Accessed May 2017.
} 


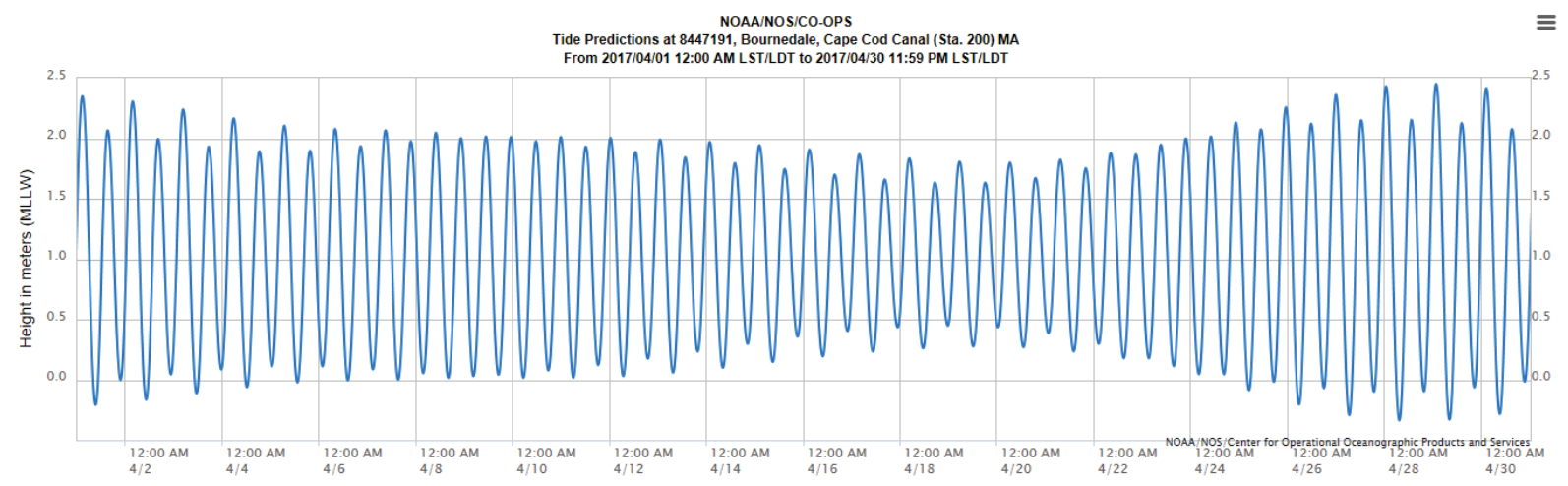

Figure D-8. Bournedale, Cape Cod Canal tide level per mean lower low water level: 30-day profile ${ }^{47}$

\footnotetext{
${ }^{47}$ National Oceanographic and Atmospheric Administration, Tides \& Currents, http://tidesandcurrents.noaa.gov/noaatidepredictions/viewDailyPredictions.jsp?Stationid=8452660. Accessed October 8, 2011.
} 


\section{Appendix E. Data Tables for 1-mile Datasets}

The following datasets and scoresheets are the raw MHK Atlas and GIS data with the screening parameters applied. These datasets were not further filtered for site suitability as the scoring datasets in the body of the report were.

The raw data of U.S. Coast Guard sites with the highest tidal current potential within a 1-mile radius are shown in the table below followed by the scores for these sites.

Table E-1. Coast Guard Sites with High Potential for Tidal Current MHK Projects at 1-mile Radius

\begin{tabular}{|c|c|c|c|c|c|c|c|c|c|}
\hline Base Name & State & DOD Branch & $\begin{array}{c}\text { Area-weighted } \\
\text { Mean TCS >0.6 } \\
\text { m/s to } 150 \mathrm{~m} \\
\text { Depth }\end{array}$ & $\begin{array}{l}\text { Maximum } \\
\text { TCS }>0.6 \mathrm{~m} / \mathrm{s} \\
\text { to } 150 \mathrm{~m} \\
\text { Depth }\end{array}$ & $\begin{array}{c}\text { Area with TCS } \\
>0.6 \mathrm{~m} / \mathrm{s} \text { to } \\
150 \mathrm{~m} \text { Depth }\end{array}$ & $\begin{array}{l}\text { Distance to } \\
\text { Area w/ TCS } \\
>0.6 \mathrm{~m} / \mathrm{s} \text { to } \\
150 \mathrm{~m}\end{array}$ & $\begin{array}{l}\text { Distance } \\
\text { to Sub- } \\
\text { station }\end{array}$ & $\begin{array}{c}\text { Total } \\
\text { Exclu- } \\
\text { sions }\end{array}$ & $\begin{array}{c}\text { Electric } \\
\text { Load }\end{array}$ \\
\hline Name & ST & DOD & $(\mathrm{m} / \mathrm{s})$ & $(\mathrm{m} / \mathrm{s})$ & $\left(\mathrm{m}^{2}\right)$ & (m) & (m) & (\#) & $(\mathrm{MW})$ \\
\hline USCG Station Portsmouth Harbor & $\mathrm{NH}$ & Coast Guard & 0.88 & 1.50 & 389,052 & 30 & 755 & 1 & 1 \\
\hline US Coast Guard, Martha's Vineyard & MA & Coast Guard & 0.82 & 1.28 & $1,106,111$ & 368 & 2,772 & 1 & 3 \\
\hline US Coast Guard Station Jones Beach & NY & Coast Guard & 0.84 & 1.04 & 380,671 & 736 & 4,582 & 1 & 2 \\
\hline US Coast Guard Station Sandy Hook & NJ & Coast Guard & 0.62 & 0.62 & 176,597 & 511 & 2,119 & 2 & 3 \\
\hline US Coast Guard Station Fire Island & NY & Coast Guard & 0.64 & 0.68 & 279,243 & 296 & 3,276 & 2 & 2 \\
\hline USCG Sector Sf-Yerba Buena Island & CA & Coast Guard & 0.60 & 0.60 & 218,580 & 394 & 7,654 & 3 & 2 \\
\hline
\end{tabular}

Table E-2. Scoring for Coast Guard Sites with High Potential for Tidal Current MHK Projects at 1mile Radius

\begin{tabular}{|c|c|c|c|c|c|c|c|c|c|c|c|}
\hline Base Name & State & DOD Branch & $\begin{array}{c}\text { Area-weighted } \\
\text { Mean TCS }>0.6 \\
\mathrm{~m} / \mathrm{s} \text { to } 150 \mathrm{~m} \\
\text { Depth }\end{array}$ & $\begin{array}{l}\text { Maximum } \\
\text { TCS }>0.6 \mathrm{~m} / \mathrm{s} \\
\text { to } 150 \mathrm{~m} \\
\text { Depth }\end{array}$ & $\begin{array}{c}\text { Area with } \\
\text { TCS }>0.6 \mathrm{~m} / \mathrm{s} \\
\text { to } 150 \mathrm{~m} \\
\text { Depth }\end{array}$ & $\begin{array}{l}\text { Distance to } \\
\text { Area w/ TCS } \\
>0.6 \mathrm{~m} / \mathrm{s} \text { to } \\
150 \mathrm{~m}\end{array}$ & $\begin{array}{c}\text { Distance } \\
\text { to Sub- } \\
\text { station }\end{array}$ & $\begin{array}{l}\text { Total } \\
\text { Exclu- } \\
\text { sions }\end{array}$ & $\begin{array}{c}\text { Electric } \\
\text { Load }\end{array}$ & $\begin{array}{l}\text { Cost of } \\
\text { Elec- } \\
\text { tricity }\end{array}$ & $\begin{array}{l}\text { Total } \\
\text { Points }\end{array}$ \\
\hline Name & ST & DOD & (pts) & (pts) & (pts) & (pts) & (pts) & (pts) & (pts) & (pts) & (pts) \\
\hline USCG Station Portsmouth Harbor & $\mathrm{NH}$ & Coast Guard & 3.6 & 5.0 & 9.0 & 10.0 & 9.1 & 10.0 & 1.2 & 3.0 & 50.9 \\
\hline US Coast Guard, Martha's Vineyard & MA & Coast Guard & 3.3 & 5.0 & 10.0 & 8.8 & 1.6 & 10.0 & 4.4 & 3.2 & 46.2 \\
\hline US Coast Guard Station Jones Beach & NY & Coast Guard & 3.4 & 3.0 & 9.0 & 6.2 & 0.0 & 10.0 & 3.2 & 3.1 & 37.9 \\
\hline US Coast Guard Station Sandy Hook & NJ & Coast Guard & 2.1 & 1.0 & 7.3 & 7.8 & 4.0 & 8.0 & 4.4 & 2.6 & 37.2 \\
\hline US Coast Guard Station Fire Island & NY & Coast Guard & 2.2 & 1.0 & 8.3 & 9.3 & 0.0 & 8.0 & 3.2 & 3.1 & 35.2 \\
\hline USCG Sector Sf-Yerba Buena Island & CA & Coast Guard & 2.0 & 1.0 & 7.8 & 8.6 & 0.0 & 6.0 & 3.2 & 3.1 & 31.8 \\
\hline
\end{tabular}

The raw data of U.S. Army sites with the highest tidal current potential within a 1-mile radius are shown in the table below followed by the scores for these sites. 
Table E-3. U.S. Army Sites with High Potential for Tidal Current MHK Projects at 1-mile Radius

\begin{tabular}{|c|c|c|c|c|c|c|c|c|c|c|}
\hline Base Name & State & DOD Branch & $\begin{array}{c}\text { Area-weighted } \\
\text { Mean TCS >0.6 } \\
\mathrm{m} / \mathrm{s} \text { to } 150 \mathrm{~m} \\
\text { Depth }\end{array}$ & \begin{tabular}{|c|} 
Maximum \\
TCS $>0.6 \mathrm{~m} / \mathrm{s}$ \\
to $150 \mathrm{~m}$ \\
Depth
\end{tabular} & $\begin{array}{c}\text { Area with TCS } \\
>0.6 \mathrm{~m} / \mathrm{s} \text { to } \\
150 \mathrm{~m} \text { Depth }\end{array}$ & $\begin{array}{c}\text { Distance to } \\
\text { Area w/ TCS } \\
>0.6 \mathrm{~m} / \mathrm{s} \text { to } \\
150 \mathrm{~m}\end{array}$ & $\begin{array}{l}\text { Distance } \\
\text { to Sub- } \\
\text { station }\end{array}$ & $\begin{array}{c}\text { Total } \\
\text { Exclu- } \\
\text { sions }\end{array}$ & $\begin{array}{c}\text { Electric } \\
\text { Load }\end{array}$ & $\begin{array}{l}\text { Cost of } \\
\text { Elec- } \\
\text { tricity }\end{array}$ \\
\hline Name & ST & DOD & $(\mathrm{m} / \mathrm{s})$ & $(\mathrm{m} / \mathrm{s})$ & $\left(m^{2}\right)$ & (m) & (m) & (\#) & (MW) & (c/kWh) \\
\hline NG Dillingham Armory & $\mathrm{AK}$ & Army Guard & 0.98 & 1.34 & $1,688,999$ & 543 & 1,796 & 1 & 2 & 17.4 \\
\hline MTA Camp Edwards & MA & Army Guard & 0.76 & 0.82 & 412,346 & 102 & 2,642 & 2 & 10 & 20.0 \\
\hline NG Buzzards Bay & MA & Army Guard & 0.76 & 0.76 & 203,888 & 673 & 517 & 1 & 2 & 15.8 \\
\hline Whittier Anchorage Pipeline & $\mathrm{AK}$ & Army Active & 0.76 & 1.01 & $3,223,792$ & 247 & 2,483 & 1 & 1 & 17.4 \\
\hline NG Anacortes & WA & Army Guard & 0.72 & 1.05 & 93,242 & 942 & 122 & 3 & 3 & 8.2 \\
\hline NG Wrangell Armory & $\mathrm{AK}$ & Army Guard & 0.68 & 0.68 & 127,261 & 1,044 & 1,025 & 1 & 2 & 17.4 \\
\hline NG Portsmouth Readiness Center & $\mathrm{NH}$ & Army Guard & 0.97 & 1.48 & 470,504 & 1,085 & 4,028 & 1 & 2 & 15.0 \\
\hline NG Petersburg Armory & AK & Army Guard & 1.86 & 1.86 & 304,442 & 1,191 & 3,652 & 0 & 2 & 17.4 \\
\hline Haines Terminal & AK & Army Active & 1.13 & 1.13 & 195,146 & 1,143 & 3,017 & 1 & 5 & 17.4 \\
\hline NG Juneau AAOF & AK & Army Guard & 0.65 & 0.70 & 169,793 & 1,308 & 1,482 & 0 & 3 & 17.4 \\
\hline NG Elizabethtown Readiness Center & OR & Army Guard & 0.83 & 0.00 & $193,189,233$ & $\# \mathrm{~N} / \mathrm{A}$ & 1,203 & 0 & 2 & 8.8 \\
\hline NG St Augustine, St Francis Barracks & $\mathrm{FL}$ & Army Guard & 0.64 & 0.67 & 402,067 & 103 & 1,698 & 5 & 3 & 9.5 \\
\hline \begin{tabular}{|l|} 
NG Newport Armory \\
\end{tabular} & OR & Army Guard & 0.66 & 0.72 & 472,223 & 975 & 1,075 & 3 & 2 & 8.8 \\
\hline NG Bronx Readiness Center & NY & Army Guard & 0.87 & 0.87 & 25,751 & 1,398 & 0 & 1 & 2 & 15.3 \\
\hline Fort Worden Cemetery & WA & Army Active & 0.73 & 0.87 & $2,719,196$ & 254 & 3,623 & 4 & 2 & 8.2 \\
\hline NG Gov Bacon Health Ctr & $\mathrm{DL}$ & Army Guard & 0.60 & 0.62 & 269,565 & 1,234 & 2,147 & 1 & 2 & 10.3 \\
\hline NG Park Ave Readiness Center & NY & Army Guard & 0.75 & 0.82 & 242,460 & 1,010 & 3,369 & 1 & 2 & 15.3 \\
\hline NG St Augustine, USP\&FO & $\mathrm{FL}$ & Army Guard & 0.64 & 0.67 & 402,067 & 197 & 17,650 & 5 & 3 & 9.5 \\
\hline NG Comptroller Louis L. Goldstein & $\mathrm{MD}$ & Army Guard & 0.83 & 0.00 & $269,997,104$ & $\# N / A$ & 3,503 & 0 & 2 & 11.0 \\
\hline AFRC Daytona Beach & $\mathrm{FL}$ & Army Guard & 0.63 & 0.63 & 204,275 & 125 & 29,648 & 5 & 2 & 9.5 \\
\hline Sp Forces Site Key West & $\mathrm{FL}$ & Army Active & 0.69 & 0.82 & 542,605 & 847 & 75,715 & 7 & 5 & 9.5 \\
\hline NG Lightner Building/City Hall & $\mathrm{FL}$ & Army Guard & 0.65 & 0.67 & 307,174 & 793 & 3,353 & 5 & 2 & 9.5 \\
\hline
\end{tabular}

Table E-4. Scoring for U.S. Army Sites with High Potential for Tidal Current MHK Projects at 1-mile Radius

\begin{tabular}{|c|c|c|c|c|c|c|c|c|c|c|c|}
\hline Base Name & State & DOD Branch & $\begin{array}{c}\text { Area-weighted } \\
\text { Mean TCS >0.6 } \\
\text { m/s to } 150 \mathrm{~m} \\
\text { Depth }\end{array}$ & $\begin{array}{c}\text { Maximum } \\
\text { TCS }>0.6 \mathrm{~m} / \mathrm{s} \\
\text { to } 150 \mathrm{~m} \\
\text { Depth }\end{array}$ & $\begin{array}{c}\text { Area with } \\
\text { TCS }>0.6 \mathrm{~m} / \mathrm{s} \\
\text { to } 150 \mathrm{~m} \\
\text { Depth }\end{array}$ & $\begin{array}{c}\text { Distance to } \\
\text { Area w/ TCS } \\
>0.6 \mathrm{~m} / \mathrm{s} \text { to } \\
150 \mathrm{~m}\end{array}$ & $\begin{array}{l}\text { Distance } \\
\text { to Sub- } \\
\text { station }\end{array}$ & $\begin{array}{c}\text { Total } \\
\text { Exclu- } \\
\text { sions }\end{array}$ & $\begin{array}{l}\text { Electric } \\
\text { Load }\end{array}$ & $\begin{array}{l}\text { Cost of } \\
\text { Elec- } \\
\text { tricity }\end{array}$ & $\begin{array}{l}\text { Total } \\
\text { Points }\end{array}$ \\
\hline Name & ST & DOD & (pts) & (pts) & (pts) & (pts) & (pts) & (pts) & (pts) & (pts) & (pts) \\
\hline NG Dillingham Armory & $\mathrm{AK}$ & Army Guard & 4.2 & 4.0 & 10.0 & 7.6 & 5.2 & 10.0 & 3.2 & 3.5 & 47.7 \\
\hline MTA Camp Edwards & MA & Army Guard & 2.9 & 1.0 & 9.2 & 10.0 & 2.1 & 8.0 & 7.9 & 4.0 & 45.1 \\
\hline NG Buzzards Bay & MA & Army Guard & 2.9 & 1.0 & 7.6 & 6.6 & 9.9 & 10.0 & 3.2 & 3.2 & 44.5 \\
\hline Whittier Anchorage Pipeline & $\mathrm{AK}$ & Army Active & 2.9 & 4.0 & 10.0 & 9.7 & 2.7 & 10.0 & 1.2 & 3.5 & 44.0 \\
\hline NG Anacortes & WA & Army Guard & 2.7 & 5.0 & 5.9 & 4.7 & 10.0 & 6.0 & 4.4 & 1.6 & 40.5 \\
\hline NG Wrangell Armory & AK & Army Guard & 2.5 & 1.0 & 6.6 & 4.0 & 8.1 & 10.0 & 3.2 & 3.5 & 38.9 \\
\hline NG Portsmouth Readiness Center & $\mathrm{NH}$ & Army Guard & 4.1 & 5.0 & 9.5 & 3.7 & 0.0 & 10.0 & 3.2 & 3.0 & 38.5 \\
\hline NG Petersburg Armory & AK & Army Guard & 9.2 & 1.0 & 8.5 & 3.0 & 0.0 & 10.0 & 3.2 & 3.5 & 38.4 \\
\hline Haines Terminal & $\mathrm{AK}$ & Army Active & 5.0 & 1.0 & 7.5 & 3.3 & 0.7 & 10.0 & 5.9 & 3.5 & 37.0 \\
\hline NG Juneau AAOF & $\mathrm{AK}$ & Army Guard & 2.3 & 1.0 & 7.2 & 2.1 & 6.4 & 10.0 & 4.4 & 3.5 & 36.9 \\
\hline NG Elizabethtown Readiness Center & OR & Army Guard & 3.3 & 1.0 & 10.0 & $\# N / A$ & 7.4 & 10.0 & 3.2 & 1.8 & 36.7 \\
\hline NG St Augustine, St Francis Barracks & $\mathrm{FL}$ & Army Guard & 2.2 & 1.0 & 9.1 & 10.0 & 5.6 & 2.0 & 4.4 & 1.9 & 36.2 \\
\hline NG Newport Armory & $\mathrm{OR}$ & Army Guard & 2.3 & 1.0 & 9.5 & 4.5 & 7.9 & 6.0 & 3.2 & 1.8 & 36.2 \\
\hline NG Bronx Readiness Center & NY & Army Guard & 3.5 & 1.0 & 3.2 & 1.5 & 10.0 & 10.0 & 3.2 & 3.1 & 35.5 \\
\hline Fort Worden Cemetery & WA & Army Active & 2.7 & 2.0 & 10.0 & 9.6 & 0.0 & 4.0 & 3.2 & 1.6 & 33.2 \\
\hline NG Gov Bacon Health Ctr & $\mathrm{DL}$ & Army Guard & 2.0 & 1.0 & 8.2 & 2.7 & 3.9 & 10.0 & 3.2 & 2.1 & 33.1 \\
\hline NG Park Ave Readiness Center & NY & Army Guard & 2.9 & 1.0 & 8.0 & 4.3 & 0.0 & 10.0 & 3.2 & 3.1 & 32.4 \\
\hline NG St Augustine, USP\&FO & $\mathrm{FL}$ & Army Guard & 2.2 & 1.0 & 9.1 & 10.0 & 0.0 & 2.0 & 4.4 & 1.9 & 30.7 \\
\hline NG Comptroller Louis L. Goldstein & MD & Army Guard & 3.3 & 1.0 & 10.0 & \#N/A & 0.0 & 10.0 & 3.2 & 2.2 & 29.8 \\
\hline AFRC Daytona Beach & $\mathrm{FL}$ & Army Guard & 2.2 & 1.0 & 7.6 & 10.0 & 0.0 & 2.0 & 3.2 & 1.9 & 28.0 \\
\hline Sp Forces Site Key West & $\mathrm{FL}$ & Army Active & 2.5 & 2.0 & 9.8 & 5.4 & 0.0 & 0.0 & 5.9 & 1.9 & 27.5 \\
\hline NG Lightner Building/City Hall & $\mathrm{FL}$ & Army Guard & 2.3 & 1.0 & 8.5 & 5.8 & 0.0 & 2.0 & 3.2 & 1.9 & 24.7 \\
\hline
\end{tabular}

The raw data of U.S. Air Force sites with the highest tidal current potential within a 1-mile radius are shown in the table below followed by the scores for these sites. 
Table E-5. U.S. Air Force Sites with High Potential for Tidal Current MHK Projects at 1-mile Radius

\begin{tabular}{|c|c|c|c|c|c|c|c|c|c|c|}
\hline Base Name & State & DOD Branch & $\begin{array}{c}\text { Area-weighted } \\
\text { Mean TCS >0.6 } \\
\text { m/s to } 150 \mathrm{~m} \\
\text { Depth }\end{array}$ & \begin{tabular}{|c|} 
Maximum \\
TCS $>0.6 \mathrm{~m} / \mathrm{s}$ \\
to $150 \mathrm{~m}$ \\
Depth
\end{tabular} & $\begin{array}{c}\text { Area with TCS } \\
>0.6 \mathrm{~m} / \mathrm{s} \text { to } \\
150 \mathrm{~m} \text { Depth }\end{array}$ & $\begin{array}{c}\text { Distance to } \\
\text { Area } w / \text { TCS } \\
>0.6 \mathrm{~m} / \mathrm{s} \text { to } \\
150 \mathrm{~m}\end{array}$ & $\begin{array}{l}\text { Distance } \\
\text { to Sub- } \\
\text { station }\end{array}$ & $\begin{array}{c}\text { Total } \\
\text { Exclu- } \\
\text { sions }\end{array}$ & $\begin{array}{c}\text { Electric } \\
\text { Load }\end{array}$ & $\begin{array}{l}\text { Cost of } \\
\text { Elec- } \\
\text { tricity }\end{array}$ \\
\hline Name & ST & DOD & $(\mathrm{m} / \mathrm{s})$ & $(\mathrm{m} / \mathrm{s})$ & $\left(\mathrm{m}^{2}\right)$ & (m) & (m) & (\#) & (MW) & (c/kWh) \\
\hline Fort Richardson & AK & AF Active & 0.82 & 1.09 & $18,867,241$ & 0 & 563 & 0 & 84 & 17.4 \\
\hline Elmendorf AFB & $\mathrm{AK}$ & AF Active & 0.80 & 1.21 & $20,411,444$ & 0 & 3,000 & 1 & 84 & 17.4 \\
\hline Newington Defense Fuel Support Point & $\mathrm{NH}$ & AF Active & 0.91 & 1.35 & $1,132,407$ & 0 & 6,499 & 1 & 2 & 15.0 \\
\hline Ipswich Antenna Farm Annex & MA & AF Active & 0.73 & 0.96 & $1,875,522$ & 219 & 2,246 & 2 & 2 & 15.8 \\
\hline Eglin AFB & $\mathrm{FL}$ & AF Active & 0.70 & 0.87 & 977,297 & 0 & 3,169 & 3 & 85 & 9.5 \\
\hline Cape Cod AS & MA & AF Active & 0.75 & 0.82 & 235,922 & 626 & 8,896 & 1 & 10 & 15.8 \\
\hline Cape Canaveral AFS & $\mathrm{FL}$ & AF Active & 0.61 & 0.61 & 200,492 & 234 & 2,701 & 9 & 40 & 9.5 \\
\hline Ship Shoal Island & VA & AF Active & 0.68 & 0.72 & 210,368 & 1,240 & 2,171 & 0 & 2 & 8.2 \\
\hline Cudjoe Key AFS & $\mathrm{FL}$ & AF Active & 0.71 & 0.72 & 257,969 & 1,221 & 1,049 & 6 & 2 & 9.5 \\
\hline Port Canaveral Cable Terminal Annex & $\mathrm{FL}$ & AF Active & 0.61 & 0.61 & 138,074 & 926 & 5,206 & 8 & 2 & 9.5 \\
\hline
\end{tabular}

Table E-6. Scoring for U.S. Air Force Sites with High Potential for Tidal Current MHK Projects at 1mile Radius

\begin{tabular}{|c|c|c|c|c|c|c|c|c|c|c|c|}
\hline Base Name & State & DOD Branch & $\begin{array}{c}\text { Area-weighted } \\
\text { Mean TCS >0.6 } \\
\mathrm{m} / \mathrm{s} \text { to } 150 \mathrm{~m} \\
\text { Depth }\end{array}$ & $\begin{array}{c}\text { Maximum } \\
\text { TCS }>0.6 \mathrm{~m} / \mathrm{s} \\
\text { to } 150 \mathrm{~m} \\
\text { Depth }\end{array}$ & $\begin{array}{c}\text { Area with } \\
\text { TCS }>0.6 \mathrm{~m} / \mathrm{s} \\
\text { to } 150 \mathrm{~m} \\
\text { Depth }\end{array}$ & $\begin{array}{c}\text { Distance to } \\
\text { Area } \mathrm{w} / \mathrm{TCS} \\
>0.6 \mathrm{~m} / \mathrm{s} \text { to } \\
150 \mathrm{~m}\end{array}$ & $\begin{array}{l}\text { Distance } \\
\text { to Sub- } \\
\text { station }\end{array}$ & $\begin{array}{l}\text { Total } \\
\text { Exclu- } \\
\text { sions }\end{array}$ & $\begin{array}{c}\text { Electric } \\
\text { Load }\end{array}$ & $\begin{array}{l}\text { Cost of } \\
\text { Elec- } \\
\text { tricity }\end{array}$ & $\begin{array}{c}\text { Total } \\
\text { Points }\end{array}$ \\
\hline Name & ST & DOD & (pts) & (pts) & (pts) & (pts) & (pts) & (pts) & (pts) & (pts) & (pts) \\
\hline Fort Richardson & $\mathrm{AK}$ & AF Active & 3.3 & 4.0 & 10.0 & 10.0 & 9.8 & 10.0 & 10.0 & 3.5 & 60.5 \\
\hline Elmendorf AFB & $\mathrm{AK}$ & AF Active & 3.2 & 5.0 & 10.0 & 10.0 & 0.8 & 10.0 & 10.0 & 3.5 & 52.4 \\
\hline Newington Defense Fuel Support Point & $\mathrm{NH}$ & AF Active & 3.8 & 5.0 & 10.0 & 10.0 & 0.0 & 10.0 & 3.2 & 3.0 & 45.0 \\
\hline Ipswich Antenna Farm Annex & $\mathrm{MA}$ & AF Active & 2.7 & 4.0 & 10.0 & 9.9 & 3.5 & 8.0 & 3.2 & 3.2 & 44.5 \\
\hline Eglin AFB & $\mathrm{FL}$ & AF Active & 2.6 & 3.0 & 10.0 & 10.0 & 0.1 & 6.0 & 10.0 & 1.9 & 43.6 \\
\hline Cape Cod AS & MA & AF Active & 2.9 & 1.0 & 8.0 & 7.0 & 0.0 & 10.0 & 7.9 & 3.2 & 39.9 \\
\hline Cape Canaveral AFS & $\mathrm{FL}$ & AF Active & 2.1 & 1.0 & 7.6 & 9.8 & 1.9 & 0.0 & 10.0 & 1.9 & 34.2 \\
\hline Ship Shoal Island & VA & AF Active & 2.5 & 1.0 & 7.7 & 2.6 & 3.8 & 10.0 & 3.2 & 1.6 & 32.5 \\
\hline Cudjoe Key AFS & $\mathrm{FL}$ & AF Active & 2.6 & 1.0 & 8.2 & 2.8 & 8.0 & 0.0 & 3.2 & 1.9 & 27.7 \\
\hline Port Canaveral Cable Terminal Annex & $\mathrm{FL}$ & AF Active & 2.1 & 1.0 & 6.8 & 4.9 & 0.0 & 0.0 & 3.2 & 1.9 & 19.8 \\
\hline
\end{tabular}

The raw data of U.S. Coast Guard sites with the highest wave energy potential within a 1-mile radius are shown in the table below followed by the scores for these sites.

Table E-7. U.S. Coast Guard Sites with High Potential for Wave Energy MHK Projects at 1-mile Radius

\begin{tabular}{|c|c|c|c|c|c|c|c|c|c|c|}
\hline Base Name & State & DOD Branch & $\begin{array}{c}\text { Area-weighted } \\
\text { Mean TCS >0.6 } \\
\text { m/s to } 150 \mathrm{~m} \\
\text { Depth }\end{array}$ & \begin{tabular}{|c|} 
Maximum \\
TCS $>0.6 \mathrm{~m} / \mathrm{s}$ \\
to $150 \mathrm{~m}$ \\
Depth
\end{tabular} & $\begin{array}{c}\text { Area with TCS } \\
>0.6 \mathrm{~m} / \mathrm{s} \text { to } \\
150 \mathrm{~m} \text { Depth }\end{array}$ & \begin{tabular}{|c|} 
Distance to \\
Area w/ TCS \\
$>0.6 \mathrm{~m} / \mathrm{s}$ to \\
$150 \mathrm{~m}$
\end{tabular} & $\begin{array}{c}\text { Distance } \\
\text { to Sub- } \\
\text { station }\end{array}$ & $\begin{array}{c}\text { Total } \\
\text { Exclu- } \\
\text { sions }\end{array}$ & $\begin{array}{c}\text { Electric } \\
\text { Load }\end{array}$ & $\begin{array}{l}\text { Cost of } \\
\text { Elec- } \\
\text { tricity }\end{array}$ \\
\hline Name & ST & DOD & $(\mathrm{m} / \mathrm{s})$ & $(\mathrm{m} / \mathrm{s})$ & $\left(m^{2}\right)$ & (m) & (m) & (\#) & (MW) & (c/kWh) \\
\hline USCG Station Portsmouth Harbor & $\mathrm{NH}$ & Coast Guard & 0.97 & 1.73 & $1,791,333$ & 30 & 755 & 1 & 1 & 15.0 \\
\hline US Coast Guard, Ocean City & $\mathrm{MD}$ & Coast Guard & 0.81 & 1.28 & $2,958,230$ & 368 & 2,772 & 1 & 4 & 15.8 \\
\hline US Coast Guard Station Sandy Hook & NJ & Coast Guard & 0.76 & 0.93 & $1,006,664$ & 511 & 2,119 & 2 & 3 & 12.8 \\
\hline US Coast Guard Training Center Cape May & NJ & Coast Guard & 0.71 & 1.04 & $18,518,975$ & 3,608 & 1,279 & 3 & 8 & 12.8 \\
\hline USCGSector Sf-Yerba Buena Island & $\mathrm{CA}$ & Coast Guard & 0.63 & 0.76 & $4,933,330$ & 394 & 7,654 & 1 & 2 & 15.7 \\
\hline US Coast Guard Station Fire Island & NY & Coast Guard & 0.77 & 1.01 & $1,828,803$ & 3,280 & 752 & 3 & 2 & 15.3 \\
\hline US Coast Guard Station Fire Island & NY & Coast Guard & 0.77 & 1.01 & $1,828,803$ & 296 & 3,276 & 4 & 2 & 15.3 \\
\hline US Coast Guard Station Jones Beach & NY & Coast Guard & 0.80 & 1.04 & 698,319 & 736 & 4,582 & 4 & 2 & 15.3 \\
\hline US Coast Guard, Martha's Vineyard & MA & Coast Guard & 0.65 & 0.87 & $12,024,690$ & 5,700 & 3,123 & 1 & 3 & 8.7 \\
\hline US Coast Guard Station Shinnecock & NY & Coast Guard & 0.97 & 1.11 & 169,292 & 1,884 & 13,117 & 1 & 2 & 15.3 \\
\hline US Coast Guard Reservation & NJ & Coast Guard & 0.69 & 0.97 & $6,320,127$ & 5,441 & 64,709 & 3 & 2 & 12.8 \\
\hline US Coast Guard Stn Islamorada & $\mathrm{FL}$ & Coast Guard & 0.85 & 1.1 & $1,194,790$ & 2,091 & 2,135 & 9 & 2 & 9.5 \\
\hline USCG Causeway Island & $\mathrm{FL}$ & Coast Guard & 0.66 & 0.7 & 225,974 & 3,894 & 3,668 & 8 & 2 & 9.5 \\
\hline
\end{tabular}


Table E-8. Scoring for U.S. Coast Guard Sites with High Potential for Wave Energy MHK Projects at 1-mile Radius

\begin{tabular}{|c|c|c|c|c|c|c|c|c|c|c|c|}
\hline Base Name & State & DOD Branch & $\begin{array}{c}\text { Area-weighted } \\
\text { Mean TCS >0.6 } \\
\text { m/s to } 150 \mathrm{~m} \\
\text { Depth }\end{array}$ & \begin{tabular}{|c|} 
Maximum \\
TCS $>0.6 \mathrm{~m} / \mathrm{s}$ \\
to $150 \mathrm{~m}$ \\
Depth
\end{tabular} & \begin{tabular}{|c|} 
Area with \\
TCS $>0.6 \mathrm{~m} / \mathrm{s}$ \\
to $150 \mathrm{~m}$ \\
Depth
\end{tabular} & $\begin{array}{c}\text { Distance to Area } \\
\text { w/ TCS }>0.6 \mathrm{~m} / \mathrm{s} \\
\text { to } 150 \mathrm{~m}\end{array}$ & $\begin{array}{l}\text { Distance } \\
\text { to Sub- } \\
\text { station }\end{array}$ & $\begin{array}{l}\text { Total } \\
\text { Exclu- } \\
\text { sions }\end{array}$ & $\begin{array}{c}\text { Electric } \\
\text { Load }\end{array}$ & $\begin{array}{l}\text { Cost of } \\
\text { Elec- } \\
\text { tricity }\end{array}$ & $\begin{array}{l}\text { Total } \\
\text { Points }\end{array}$ \\
\hline Name & ST & DOD & (pts) & (pts) & (pts) & (pts) & (pts) & (pts) & (pts) & (pts) & (pts) \\
\hline USCG Station Portsmouth Harbor & $\mathrm{NH}$ & Coast Guard & 4.1 & 5.0 & 10.0 & 10.0 & 9.1 & 10.0 & 1.2 & 3.0 & 52.4 \\
\hline US Coast Guard, Ocean City & $\mathrm{MD}$ & Coast Guard & 3.2 & 5.0 & 10.0 & 8.8 & 1.6 & 10.0 & 5.3 & 3.2 & 47.0 \\
\hline US Coast Guard Station Sandy Hook & NJ & Coast Guard & 2.9 & 3.0 & 10.0 & 7.8 & 4.0 & 8.0 & 4.4 & 2.6 & 42.7 \\
\hline US Coast Guard Training Center Cape May & NJ & Coast Guard & 2.6 & 5.0 & 10.0 & 0.0 & 7.1 & 6.0 & 7.3 & 2.6 & 40.6 \\
\hline USCGSector Sf-Yerba Buena Island & CA & Coast Guard & 2.2 & 2.0 & 10.0 & 8.6 & 0.0 & 10.0 & 3.2 & 3.1 & 39.2 \\
\hline US Coast Guard Station Fire Island & NY & Coast Guard & 3.0 & 4.0 & 10.0 & 0.0 & 9.1 & 6.0 & 3.2 & 3.1 & 38.3 \\
\hline US Coast Guard Station Fire Island & NY & Coast Guard & 3.0 & 4.0 & 10.0 & 9.3 & 0.0 & 4.0 & 3.2 & 3.1 & 36.6 \\
\hline US Coast Guard Station Jones Beach & NY & Coast Guard & 3.1 & 4.0 & 10.0 & 6.2 & 0.0 & 4.0 & 3.2 & 3.1 & 33.6 \\
\hline US Coast Guard, Martha's Vineyard & MA & Coast Guard & 2.3 & 4.0 & 10.0 & 0.0 & 0.3 & 10.0 & 4.4 & 1.7 & 32.8 \\
\hline US Coast Guard Station Shinnecock & NY & Coast Guard & 4.1 & 2.0 & 7.2 & 0.0 & 0.0 & 10.0 & 3.2 & 3.1 & 29.7 \\
\hline US Coast Guard Reservation & NJ & Coast Guard & 2.5 & 5.0 & 10.0 & 0.0 & 0.0 & 6.0 & 3.2 & 2.6 & 29.3 \\
\hline US Coast Guard Stn Islamorada & $\mathrm{FL}$ & Coast Guard & 3.4 & 3.0 & 10.0 & 0.0 & 4.0 & 0.0 & 3.2 & 1.9 & 25.5 \\
\hline USCG Causeway Island & $\mathrm{FL}$ & Coast Guard & 2.4 & 1.0 & 7.9 & 0.0 & 0.0 & 0.0 & 3.2 & 1.9 & 16.4 \\
\hline
\end{tabular}


The raw data of U.S. Army sites with the highest wave energy potential within a 1-mile radius are shown in the table below followed by the scores for these sites.

Table E-9. U.S. Army Sites with High Potential for Wave Energy MHK Projects at 1-mile Radius

\begin{tabular}{|c|c|c|c|c|c|c|c|c|c|c|}
\hline Base Name & State & DOD Branch & $\begin{array}{c}\text { Area-weighted } \\
\text { Mean TCS >0.6 } \\
\text { m/s to } 150 \mathrm{~m} \\
\text { Depth }\end{array}$ & $\begin{array}{c}\text { Maximum } \\
\text { TCS }>0.6 \mathrm{~m} / \mathrm{s} \\
\text { to } 150 \mathrm{~m} \\
\text { Depth }\end{array}$ & $\begin{array}{c}\text { Area with TCS } \\
>0.6 \mathrm{~m} / \mathrm{s} \text { to } \\
150 \mathrm{~m} \text { Depth }\end{array}$ & $\begin{array}{c}\text { Distance to } \\
\text { Area w/ TCS } \\
>0.6 \mathrm{~m} / \mathrm{s} \text { to } \\
150 \mathrm{~m}\end{array}$ & $\begin{array}{l}\text { Distance } \\
\text { to Sub- } \\
\text { station }\end{array}$ & $\begin{array}{c}\text { Total } \\
\text { Exclu- } \\
\text { sions }\end{array}$ & $\begin{array}{c}\text { Electric } \\
\text { Load }\end{array}$ & $\begin{array}{c}\text { Cost of } \\
\text { Elec- } \\
\text { tricity }\end{array}$ \\
\hline Name & ST & DOD & $(\mathrm{m} / \mathrm{s})$ & $(\mathrm{m} / \mathrm{s})$ & $\left(m^{2}\right)$ & $(\mathrm{m})$ & $(\mathrm{m})$ & (\#) & (MW) & $(\mathrm{c} / \mathrm{kWh}$ \\
\hline NG St Augustine, St Francis Barracks & $\mathrm{FL}$ & Army Guard & 0.75 & 1.02 & 940,562 & 103 & 1,698 & 0 & 2 & 9.5 \\
\hline NG Dillingham Armory & $\mathrm{AK}$ & Army Guard & 0.95 & 1.44 & $37,292,802$ & 543 & 1,796 & 2 & 2 & 17.4 \\
\hline NG Lexington Ave Readiness Ctr & NY & Army Guard & 0.81 & 1.45 & $3,376,886$ & 1,741 & 764 & 1 & 1 & 15.3 \\
\hline NG Petersburg Armory & $\mathrm{AK}$ & Army Guard & 1.86 & 1.86 & $1,280,043$ & 1,191 & 3,652 & 1 & 2 & 17.4 \\
\hline NG Fifth Ave Readiness Center & NY & Army Guard & 0.88 & 1.45 & $1,991,979$ & 2,422 & 1,154 & 2 & 1 & 15.3 \\
\hline \begin{tabular}{|l|} 
NG Juneau Armory and FMS \\
\end{tabular} & $\mathrm{AK}$ & Army Guard & 0.64 & 0.7 & $1,347,707$ & 5,019 & 1,184 & 0 & 2 & 17.4 \\
\hline NG Anacortes & WA & Army Guard & 0.88 & 1.26 & $13,289,018$ & 942 & 122 & 8 & 2 & 8.2 \\
\hline MTA Camp Edwards & MA & Army Guard & 0.73 & 0.97 & $1,813,213$ & 102 & 2,642 & 9 & 4 & 20.0 \\
\hline NG St Augustine, USP\&FO & $\mathrm{FL}$ & Army Guard & 0.75 & 1.02 & 940,562 & 197 & 17,650 & 3 & 2 & 9.5 \\
\hline NG Jewel Lake Armory & $\mathrm{AK}$ & Army Guard & 0.81 & 0.95 & $24,889,080$ & 4,190 & 1,637 & 1 & 2 & 17.4 \\
\hline NG Buzzards Bay & MA & Army Guard & 0.71 & 0.82 & $1,181,477$ & 673 & 517 & 10 & 2 & 15.8 \\
\hline \begin{tabular}{|l|} 
Fort Monmouth Main Post \\
\end{tabular} & NJ & Army Active & 0.68 & 0.97 & 557,648 & 7,009 & 2,170 & 2 & 5 & 12.8 \\
\hline Sp Forces Site Key West & $\mathrm{FL}$ & Army Active & 0.74 & 1.01 & $18,061,928$ & 847 & 75,715 & 1 & 2 & 9.5 \\
\hline NG Cape May & $\mathrm{NJ}$ & Army Guard & 0.72 & 0.83 & 696,964 & 6,909 & 603 & 3 & 3 & 12.8 \\
\hline Whittier Anchorage Pipeline & $\mathrm{AK}$ & Army Active & 0.80 & 1.21 & $92,062,057$ & 247 & 2,483 & 5 & 1 & 17.4 \\
\hline NG Barnstable & MA & Army Guard & 0.66 & 0.72 & $2,290,491$ & 5,016 & 694 & 2 & 2 & 15.8 \\
\hline \begin{tabular}{|l} 
Fort Lewis \\
\end{tabular} & WA & Army Active & 0.64 & 0.67 & $1,094,336$ & 6,084 & 228 & 5 & 113 & 8.2 \\
\hline NG Atlantic City & $\mathrm{NJ}$ & Army Guard & 0.86 & 1.25 & 546,035 & 1,883 & 1,685 & 3 & 3 & 12.8 \\
\hline NG Park Ave Readiness Center & NY & Army Guard & 0.82 & 1.45 & $3,245,646$ & 1,010 & 3,369 & 1 & 1 & 15.3 \\
\hline \begin{tabular}{|l|} 
NG River Road Training Site \\
\end{tabular} & $\mathrm{DL}$ & Army Guard & 0.61 & 0.65 & 761,050 & 5,819 & 443 & 2 & 2 & 10.3 \\
\hline NG Gov Bacon Health Ctr & $\mathrm{DL}$ & Army Guard & 0.66 & 0.74 & $8,407,904$ & 1,234 & 2,147 & 1 & 2 & 10.3 \\
\hline Fort Worden Cemetery & WA & Army Active & 0.70 & 0.89 & $46,298,273$ & 254 & 3,623 & 3 & 2 & 8.2 \\
\hline \begin{tabular}{|l|} 
NG Wrangell Armory \\
\end{tabular} & AK & Army Guard & 0.83 & 1.08 & $20,435,768$ & 1,044 & 1,025 & 9 & 2 & 17.4 \\
\hline \begin{tabular}{|l|} 
NG Bremerton \\
\end{tabular} & WA & Army Guard & 0.81 & 1 & 643,510 & 3,716 & 1,213 & 3 & 3 & 8.2 \\
\hline \begin{tabular}{|l|} 
NG Falmouth \\
\end{tabular} & MA & Army Guard & 0.82 & 1.76 & $30,503,534$ & 4,313 & 1,937 & 3 & 2 & 15.8 \\
\hline \begin{tabular}{|l|} 
NG Calais Armory \\
\end{tabular} & ME & Army Guard & 1.39 & 2 & $23,012,512$ & 4,166 & 4,660 & 0 & 1 & 12.5 \\
\hline AFRC Daytona Beach & $\mathrm{FL}$ & Army Guard & 0.63 & 0.63 & 204,275 & 125 & 29,648 & 2 & 3 & 9.5 \\
\hline NG Portsmouth Readiness Center & $\mathrm{NH}$ & Army Guard & 0.92 & 1.73 & $3,173,121$ & 1,085 & 4,028 & 3 & 2 & 15.0 \\
\hline \begin{tabular}{|l|} 
NG Juneau AAOF \\
\end{tabular} & $\mathrm{AK}$ & Army Guard & 0.64 & 0.7 & $1,347,707$ & 1,308 & 1,482 & 4 & 3 & 17.4 \\
\hline NG Coos Bay Armory & OR & Army Guard & 0.97 & 1.33 & 954,288 & 6,712 & 1,292 & 4 & 2 & 8.8 \\
\hline NG Marcy Ave Readiness Center & NY & Army Guard & 0.74 & 1.06 & $2,203,454$ & 1,632 & 22,310 & 1 & 2 & 15.3 \\
\hline \begin{tabular}{|l|} 
NG Jersey City \\
\end{tabular} & $\mathrm{NJ}$ & Army Guard & 0.73 & 0.99 & $1,400,612$ & 4,315 & 16,997 & 1 & 3 & 12.8 \\
\hline NG Bedford Ave RC OMS 12 & NY & Army Guard & 0.73 & 0.99 & $1,559,782$ & 4,482 & 6,811 & 1 & 2 & 15.3 \\
\hline NG Yonkers Readiness Center & NY & Army Guard & 0.61 & 0.85 & 38,604 & 7,044 & 879 & 2 & 2 & 15.3 \\
\hline \begin{tabular}{|l|} 
NG Newport Armory \\
\end{tabular} & OR & Army Guard & 0.66 & 0.72 & 472,223 & 975 & 1,075 & 5 & 2 & 8.8 \\
\hline NG Tacoma & WA & Army Guard & 1.12 & 1.64 & $2,689,965$ & 7,027 & 4,628 & 3 & 3 & 8.2 \\
\hline NG Lightner Building/City Hall & $\mathrm{FL}$ & Army Guard & 0.75 & 1.02 & 940,562 & 793 & 3,353 & 4 & 2 & 9.5 \\
\hline NG Port Orchard & WA & Army Guard & 0.90 & 1.26 & $1,170,042$ & 4,071 & 1,931 & 4 & 2 & 8.2 \\
\hline NG Bronx Readiness Center & NY & Army Guard & 0.83 & 0.93 & 206,607 & 1,398 & 2,000 & 3 & 2 & 15.3 \\
\hline NG Kenai Armory & $\mathrm{AK}$ & Army Guard & 0.67 & 0.76 & $24,546,811$ & 4,850 & 12,171 & 1 & 2 & 17.4 \\
\hline \begin{tabular}{|l|} 
NG Eureka \\
\end{tabular} & $\mathrm{CA}$ & Army Guard & 0.78 & 0.95 & 805,806 & 6,737 & 2,310 & 4 & 3 & 15.7 \\
\hline NG Newburyport & MA & Army Guard & 0.74 & 1.08 & $2,103,967$ & 2,053 & 4,095 & 3 & 2 & 15.8 \\
\hline NG Staten Island RC OMS 14 & NY & Army Guard & 0.68 & 0.73 & 395,898 & 2,414 & 3,000 & 1 & 2 & 15.3 \\
\hline \begin{tabular}{|l|} 
Haines Terminal \\
\end{tabular} & $\mathrm{AK}$ & Army Active & 1.13 & 1.13 & $3,063,910$ & 1,143 & 3,017 & 6 & 5 & 17.4 \\
\hline NG Poulsbo & WA & Army Guard & 0.83 & 1 & 296,744 & 6,654 & 2,241 & 3 & 2 & 8.2 \\
\hline NG St Augustine, Mark Lance Readiness Cer & $\mathrm{FL}$ & Army Guard & 0.75 & 1.02 & 940,562 & 2,538 & 1,321 & 7 & 2 & 9.5 \\
\hline \begin{tabular}{|l|l} 
NG San Jose Malech \\
\end{tabular} & $\mathrm{CA}$ & Army Guard & 0.61 & 0.61 & 76,897 & 7,335 & 2,436 & 1 & 2 & 15.7 \\
\hline NG Teaneck & NJ & Army Guard & 0.61 & 0.85 & 38,604 & 6,649 & 3,000 & 2 & 3 & 12.8 \\
\hline NG Hingham & MA & Army Guard & 0.65 & 0.7 & 125,803 & 7,527 & 10,605 & 2 & 2 & 15.8 \\
\hline NG San Francisco & $\mathrm{CA}$ & Army Guard & 0.61 & 0.62 & 76,970 & 6,303 & 22,092 & 2 & 3 & 15.7 \\
\hline NG Fort Pierce Readiness Center & $\mathrm{FL}$ & Army Guard & 0.84 & 1.26 & $4,177,478$ & 3,021 & 6,335 & 8 & 2 & 9.5 \\
\hline \begin{tabular}{|l|l} 
NG Vallejo \\
\end{tabular} & $\mathrm{CA}$ & Army Guard & 0.62 & 0.66 & 959,151 & 3,846 & 10,680 & 4 & 2 & 15.7 \\
\hline NG St Petersburg Readiness Center & $\mathrm{FL}$ & Army Guard & 0.66 & 0.85 & 696,113 & 3,935 & 27,941 & 5 & 2 & 9.5 \\
\hline \begin{tabular}{|l|} 
NG Newport Airport Property \\
\end{tabular} & $\mathrm{OR}$ & Army Guard & 0.66 & 0.72 & 472,223 & 5,456 & 3,996 & 8 & 2 & 8.8 \\
\hline NG St Augustine, Ensslin Readiness Ctr & $\mathrm{FL}$ & Army Guard & 0.63 & 0.63 & 71,649 & 7,761 & 16,202 & 5 & 3 & 9.5 \\
\hline NG Brunswick & GA & Army Guard & 0.60 & 0.6 & 49,825 & 7,661 & 3,116 & 5 & 2 & 9.9 \\
\hline
\end{tabular}


Table E-10. Scoring for U.S. Army Sites with High Potential for Wave Energy MHK Projects at 1mile Radius

\begin{tabular}{|c|c|c|c|c|c|c|c|c|c|c|c|}
\hline Base Name & State & DOD Branch & $\begin{array}{c}\text { Area-weighted } \\
\text { Mean TCS >0.6 } \\
\mathrm{m} / \mathrm{s} \text { to } 150 \mathrm{~m} \\
\text { Depth }\end{array}$ & \begin{tabular}{|c|} 
Maximum \\
TCS $>0.6 \mathrm{~m} / \mathrm{s}$ \\
to $150 \mathrm{~m}$ \\
Depth
\end{tabular} & \begin{tabular}{|c|} 
Area with \\
TCS $>0.6 \mathrm{~m} / \mathrm{s}$ \\
to $150 \mathrm{~m}$ \\
Depth
\end{tabular} & $\begin{array}{c}\text { Distance to Area } \\
\mathrm{w} / \mathrm{TCS}>0.6 \mathrm{~m} / \mathrm{s} \\
\text { to } 150 \mathrm{~m}\end{array}$ & $\begin{array}{l}\text { Distance } \\
\text { to Sub- } \\
\text { station }\end{array}$ & $\begin{array}{l}\text { Total } \\
\text { Exclu- } \\
\text { sions }\end{array}$ & $\begin{array}{c}\text { Electric } \\
\text { Load }\end{array}$ & $\begin{array}{l}\text { Cost of } \\
\text { Elec- } \\
\text { tricity }\end{array}$ & $\begin{array}{l}\text { Total } \\
\text { Points }\end{array}$ \\
\hline Name & ST & DOD & (pts) & (pts) & (pts) & (pts) & (pts) & (pts) & (pts) & (pts) & (pts) \\
\hline NG St Augustine, St Francis Barracks & $\mathrm{FL}$ & Army Guard & 2.8 & 4.0 & 10.0 & 10.0 & 5.6 & 10.0 & 3.2 & 1.9 & 47.5 \\
\hline NG Dillingham Armory & AK & Army Guard & 4.0 & 5.0 & 10.0 & 7.6 & 5.2 & 8.0 & 3.2 & 3.5 & 46.5 \\
\hline NG Lexington Ave Readiness Ctr & NY & Army Guard & 3.2 & 5.0 & 10.0 & 0.0 & 9.0 & 10.0 & 1.2 & 3.1 & 41.5 \\
\hline \begin{tabular}{|l|} 
NG Petersburg Armory \\
\end{tabular} & AK & Army Guard & 9.2 & 1.0 & 10.0 & 3.0 & 0.0 & 10.0 & 3.2 & 3.5 & 39.9 \\
\hline NG Fifth Ave Readiness Center & NY & Army Guard & 3.6 & 5.0 & 10.0 & 0.0 & 7.6 & 8.0 & 1.2 & 3.1 & 38.5 \\
\hline NG Juneau Armory and FMS & AK & Army Guard & 2.2 & 2.0 & 10.0 & 0.0 & 7.5 & 10.0 & 3.2 & 3.5 & 38.4 \\
\hline NG Anacortes & WA & Army Guard & 3.6 & 5.0 & 10.0 & 4.7 & 10.0 & 0.0 & 3.2 & 1.6 & 38.2 \\
\hline MTA Camp Edwards & MA & Army Guard & 2.7 & 4.0 & 10.0 & 10.0 & 2.1 & 0.0 & 5.3 & 4.0 & 38.1 \\
\hline NG St Augustine, USP\&FO & $\mathrm{FL}$ & Army Guard & 2.8 & 4.0 & 10.0 & 10.0 & 0.0 & 6.0 & 3.2 & 1.9 & 38.0 \\
\hline NG Jewel Lake Armory & AK & Army Guard & 3.2 & 2.0 & 10.0 & 0.0 & 5.8 & 10.0 & 3.2 & 3.5 & 37.8 \\
\hline NG Buzzards Bay & MA & Army Guard & 2.7 & 2.0 & 10.0 & 6.6 & 9.9 & 0.0 & 3.2 & 3.2 & 37.6 \\
\hline Fort Monmouth Main Post & NJ & Army Active & 2.5 & 5.0 & 9.8 & 0.0 & 3.8 & 8.0 & 5.9 & 2.6 & 37.6 \\
\hline Sp Forces Site Key West & $\mathrm{FL}$ & Army Active & 2.8 & 4.0 & 10.0 & 5.4 & 0.0 & 10.0 & 3.2 & 1.9 & 37.4 \\
\hline NG Cape May & NJ & Army Guard & 2.7 & 2.0 & 10.0 & 0.0 & 9.6 & 6.0 & 4.4 & 2.6 & 37.3 \\
\hline Whittier Anchorage Pipeline & AK & Army Active & 3.1 & 5.0 & 10.0 & 9.7 & 2.7 & 2.0 & 1.2 & 3.5 & 37.2 \\
\hline NG Barnstable & MA & Army Guard & 2.3 & 1.0 & 10.0 & 0.0 & 9.3 & 8.0 & 3.2 & 3.2 & 37.0 \\
\hline Fort Lewis & WA & Army Active & 2.2 & 1.0 & 10.0 & 0.0 & 10.0 & 2.0 & 10.0 & 1.6 & 36.9 \\
\hline NG Atlantic City & NJ & Army Guard & 3.5 & 5.0 & 9.8 & 0.0 & 5.6 & 6.0 & 4.4 & 2.6 & 36.9 \\
\hline NG Park Ave Readiness Center & NY & Army Guard & 3.2 & 5.0 & 10.0 & 4.3 & 0.0 & 10.0 & 1.2 & 3.1 & 36.8 \\
\hline NG River Road Training Site & $\mathrm{DL}$ & Army Guard & 2.1 & 1.0 & 10.0 & 0.0 & 10.0 & 8.0 & 3.2 & 2.1 & 36.3 \\
\hline NG Gov Bacon Health Ctr & $\mathrm{DL}$ & Army Guard & 2.3 & 2.0 & 10.0 & 2.7 & 3.9 & 10.0 & 3.2 & 2.1 & 36.2 \\
\hline Fort Worden Cemetery & WA & Army Active & 2.6 & 3.0 & 10.0 & 9.6 & 0.0 & 6.0 & 3.2 & 1.6 & 36.1 \\
\hline NG Wrangell Armory & AK & Army Guard & 3.3 & 4.0 & 10.0 & 4.0 & 8.1 & 0.0 & 3.2 & 3.5 & 36.1 \\
\hline \begin{tabular}{|l|} 
NG Bremerton \\
\end{tabular} & WA & Army Guard & 3.2 & 3.0 & 10.0 & 0.0 & 7.4 & 6.0 & 4.4 & 1.6 & 35.6 \\
\hline NG Falmouth & $\mathrm{MA}$ & Army Guard & 3.3 & 5.0 & 10.0 & 0.0 & 4.7 & 6.0 & 3.2 & 3.2 & 35.4 \\
\hline NG Calais Armory & $\mathrm{ME}$ & Army Guard & 6.5 & 5.0 & 10.0 & 0.0 & 0.0 & 10.0 & 1.2 & 2.5 & 35.2 \\
\hline AFRC Daytona Beach & $\mathrm{FL}$ & Army Guard & 2.2 & 1.0 & 7.6 & 10.0 & 0.0 & 8.0 & 4.4 & 1.9 & 35.1 \\
\hline NG Portsmouth Readiness Center & $\mathrm{NH}$ & Army Guard & 3.8 & 5.0 & 10.0 & 3.7 & 0.0 & 6.0 & 3.2 & 3.0 & 34.8 \\
\hline NG Juneau AAOF & $\mathrm{AK}$ & Army Guard & 2.2 & 2.0 & 10.0 & 2.1 & 6.4 & 4.0 & 4.4 & 3.5 & 34.6 \\
\hline NG Coos Bay Armory & OR & Army Guard & 4.1 & 4.0 & 10.0 & 0.0 & 7.1 & 4.0 & 3.2 & 1.8 & 34.2 \\
\hline NG Marcy Ave Readiness Center & NY & Army Guard & 2.8 & 5.0 & 10.0 & 0.0 & 0.0 & 10.0 & 3.2 & 3.1 & 34.1 \\
\hline NG Jersey City & NJ & Army Guard & 2.7 & 4.0 & 10.0 & 0.0 & 0.0 & 10.0 & 4.4 & 2.6 & 33.7 \\
\hline NG Bedford Ave RC OMS 12 & NY & Army Guard & 2.7 & 4.0 & 10.0 & 0.0 & 0.0 & 10.0 & 3.2 & 3.1 & 33.0 \\
\hline NG Yonkers Readiness Center & NY & Army Guard & 2.1 & 4.0 & 4.0 & 0.0 & 8.6 & 8.0 & 3.2 & 3.1 & 33.0 \\
\hline NG Newport Armory & OR & Army Guard & 2.3 & 1.0 & 9.5 & 4.5 & 7.9 & 2.0 & 3.2 & 1.8 & 32.2 \\
\hline NG Tacoma & WA & Army Guard & 5.0 & 5.0 & 10.0 & 0.0 & 0.0 & 6.0 & 4.4 & 1.6 & 32.1 \\
\hline NG Lightner Building/City Hall & $\mathrm{FL}$ & Army Guard & 2.8 & 4.0 & 10.0 & 5.8 & 0.0 & 4.0 & 3.2 & 1.9 & 31.8 \\
\hline NG Port Orchard & WA & Army Guard & 3.7 & 4.0 & 10.0 & 0.0 & 4.7 & 4.0 & 3.2 & 1.6 & 31.3 \\
\hline NG Bronx Readiness Center & NY & Army Guard & 3.3 & 2.0 & 7.7 & 1.5 & 4.5 & 6.0 & 3.2 & 3.1 & 31.2 \\
\hline NG Kenai Armory & AK & Army Guard & 2.4 & 2.0 & 10.0 & 0.0 & 0.0 & 10.0 & 3.2 & 3.5 & 31.1 \\
\hline NG Eureka & $\mathrm{CA}$ & Army Guard & 3.0 & 3.0 & 10.0 & 0.0 & 3.3 & 4.0 & 4.4 & 3.1 & 30.9 \\
\hline NG Newburyport & MA & Army Guard & 2.8 & 5.0 & 10.0 & 0.0 & 0.0 & 6.0 & 3.2 & 3.2 & 30.2 \\
\hline NG Staten Island RC OMS 14 & NY & Army Guard & 2.4 & 1.0 & 9.1 & 0.0 & 0.8 & 10.0 & 3.2 & 3.1 & 29.6 \\
\hline Haines Terminal & $A K$ & Army Active & 5.0 & 1.0 & 10.0 & 3.3 & 0.7 & 0.0 & 5.9 & 3.5 & 29.4 \\
\hline NG Poulsbo & WA & Army Guard & 3.3 & 3.0 & 8.5 & 0.0 & 3.6 & 6.0 & 3.2 & 1.6 & 29.2 \\
\hline NG St Augustine, Mark Lance Readiness Cer & $\mathrm{FL}$ & Army Guard & 2.8 & 4.0 & 10.0 & 0.0 & 7.0 & 0.0 & 3.2 & 1.9 & 28.9 \\
\hline \begin{tabular}{|l|} 
NG San Jose Malech \\
\end{tabular} & $\mathrm{CA}$ & Army Guard & 2.1 & 1.0 & 5.5 & 0.0 & 2.8 & 10.0 & 3.2 & 3.1 & 27.8 \\
\hline NG Teaneck & NJ & Army Guard & 2.1 & 4.0 & 4.0 & 0.0 & 0.8 & 8.0 & 4.4 & 2.6 & 25.8 \\
\hline NG Hingham & MA & Army Guard & 2.3 & 1.0 & 6.6 & 0.0 & 0.0 & 8.0 & 3.2 & 3.2 & 24.3 \\
\hline NG San Francisco & CA & Army Guard & 2.1 & 1.0 & 5.5 & 0.0 & 0.0 & 8.0 & 4.4 & 3.1 & 24.2 \\
\hline NG Fort Pierce Readiness Center & $\mathrm{FL}$ & Army Guard & 3.4 & 5.0 & 10.0 & 0.0 & 0.0 & 0.0 & 3.2 & 1.9 & 23.5 \\
\hline NG Vallejo & $\mathrm{CA}$ & Army Guard & 2.1 & 1.0 & 10.0 & 0.0 & 0.0 & 4.0 & 3.2 & 3.1 & 23.5 \\
\hline NG St Petersburg Readiness Center & $\mathrm{FL}$ & Army Guard & 2.3 & 3.0 & 10.0 & 0.0 & 0.0 & 2.0 & 3.2 & 1.9 & 22.5 \\
\hline NG Newport Airport Property & OR & Army Guard & 2.3 & 1.0 & 9.5 & 0.0 & 0.0 & 0.0 & 3.2 & 1.8 & 17.8 \\
\hline NG St Augustine, Ensslin Readiness Ctr & $\mathrm{FL}$ & Army Guard & 2.2 & 1.0 & 5.4 & 0.0 & 0.0 & 2.0 & 4.4 & 1.9 & 16.9 \\
\hline NG Brunswick & GA & Army Guard & 2.0 & 1.0 & 4.6 & 0.0 & 0.3 & 2.0 & 3.2 & 2.0 & 15.1 \\
\hline
\end{tabular}


The raw data of U.S. Air Force sites with the highest wave energy potential within a 1-mile radius are shown in the table below followed by the scores for these sites.

\section{Table E-11. U.S. Air Force Sites with High Potential for Wave Energy MHK Projects at 1-mile Radius}

\begin{tabular}{|c|c|c|c|c|c|c|c|c|c|c|}
\hline Base Name & State & DOD Branch & $\begin{array}{c}\text { Area-weighted } \\
\text { Mean TCS >0.6 } \\
\text { m/s to } 150 \mathrm{~m} \\
\text { Depth }\end{array}$ & $\begin{array}{c}\text { Maximum } \\
\text { TCS }>0.6 \mathrm{~m} / \mathrm{s} \\
\text { to } 150 \mathrm{~m} \\
\text { Depth }\end{array}$ & $\begin{array}{c}\text { Area with TCS } \\
>0.6 \mathrm{~m} / \mathrm{s} \text { to } \\
150 \mathrm{~m} \text { Depth }\end{array}$ & \begin{tabular}{|c|} 
Distance to \\
Area w/ TCS \\
$>0.6 \mathrm{~m} / \mathrm{s}$ to \\
$150 \mathrm{~m}$
\end{tabular} & $\begin{array}{c}\text { Distance } \\
\text { to Sub- } \\
\text { station }\end{array}$ & $\begin{array}{c}\text { Total } \\
\text { Exclu- } \\
\text { sions }\end{array}$ & $\begin{array}{c}\text { Electric } \\
\text { Load }\end{array}$ & $\begin{array}{l}\text { Cost of } \\
\text { Elec- } \\
\text { tricity }\end{array}$ \\
\hline Name & ST & DOD & $(\mathrm{m} / \mathrm{s})$ & $(\mathrm{m} / \mathrm{s})$ & $\left(\mathrm{m}^{2}\right)$ & (m) & $(\mathrm{m})$ & (\#) & $(\mathrm{MW})$ & (c/kWh) \\
\hline Fort Richardson & $\mathrm{AK}$ & AF Active & 0.86 & 1.29 & $124,202,085$ & 0 & 563 & 6 & 84 & \begin{tabular}{|l|}
17.4 \\
\end{tabular} \\
\hline Eglin AFB & $\mathrm{FL}$ & AF Active & 0.70 & 0.87 & 977,297 & 0 & 3,169 & 1 & 85 & 9.5 \\
\hline Cape Cod AS & MA & AF Active & 0.73 & 0.97 & $1,650,137$ & 626 & 8,896 & 1 & 10 & 15.8 \\
\hline \begin{tabular}{|l} 
Ipswich Antenna Farm Annex \\
\end{tabular} & MA & AF Active & 0.70 & 0.96 & $3,444,811$ & 219 & 2,246 & 2 & 2 & 15.8 \\
\hline Elmendorf AFB & $A K$ & AF Active & 0.86 & 1.29 & $124,555,118$ & 0 & 3,000 & 9 & 84 & 17.4 \\
\hline Cudjoe Key AFS & $\mathrm{FL}$ & AF Active & 0.70 & 0.94 & $6,819,258$ & 1,221 & 1,049 & 2 & 2 & 9.5 \\
\hline Cape Newenham Long Range Radar Site & $\mathrm{AK}$ & AF Active & 0.86 & 1.67 & $61,173,056$ & 1,977 & 13,590 & 1 & 5 & 17.4 \\
\hline Newington Defense Fuel Support Point & $\mathrm{NH}$ & AF Active & 0.94 & 1.73 & $2,925,744$ & 0 & 6,499 & 7 & 2 & 15.0 \\
\hline MacDill AFB & $\mathrm{FL}$ & AF Active & 0.60 & 0.6 & 153,024 & 1,700 & 1,348 & 3 & 27 & 9.5 \\
\hline \begin{tabular}{|l|} 
Cape Canaveral AFS \\
\end{tabular} & $\mathrm{FL}$ & AF Active & 0.61 & 0.61 & 200,492 & 234 & 2,701 & 6 & 40 & 9.5 \\
\hline Naknek Recreation Annex \#2 & $\mathrm{AK}$ & AF Active & 0.70 & 0.92 & $19,755,481$ & 3,742 & 19,896 & 1 & 2 & 17.4 \\
\hline Ship Shoal Island & VA & AF Active & 0.66 & 0.83 & $1,584,087$ & 1,240 & 2,171 & 3 & 2 & 8.2 \\
\hline LWTC, NFAC Site \#1 & $\mathrm{CA}$ & AF Active & 0.70 & 0.7 & 158,065 & 7,387 & 966 & 3 & 3 & 15.7 \\
\hline Port Heiden Radio Relay Site & $\mathrm{AK}$ & AF Active & 0.77 & 1.04 & $7,684,634$ & 1,953 & 3,000 & 2 & 2 & 17.4 \\
\hline Hurlburt Field & $\mathrm{FL}$ & AF Active & 0.66 & 0.66 & 36,897 & 2,517 & 229 & 2 & 4 & 9.5 \\
\hline \begin{tabular}{|l|} 
Sagamore Hill Electronics Research Annex \\
\end{tabular} & MA & AF Active & 0.66 & 0.76 & $1,372,063$ & 7,016 & 6,427 & 1 & 2 & 15.8 \\
\hline \begin{tabular}{|l|} 
Clausen Missile Tracking Annex \\
\end{tabular} & $\mathrm{FL}$ & AF Active & 0.70 & 0.87 & 940,400 & 5,962 & 4,174 & 2 & 2 & 9.5 \\
\hline Onizuka AFB & $\mathrm{CA}$ & AF Active & 0.70 & 0.7 & 158,065 & 6,626 & 5,552 & 3 & 2 & 15.7 \\
\hline \begin{tabular}{|l|} 
Port Canaveral Cable Terminal Annex \\
\end{tabular} & $\mathrm{FL}$ & AF Active & 0.61 & 0.61 & 200,492 & 926 & 5,206 & 6 & 2 & 9.5 \\
\hline Tel 4 Area Located On Kennedy Space Ctr & $\mathrm{FL}$ & AF Active & 0.61 & 0.61 & 200,492 & 4,457 & 3,102 & 9 & 2 & 9.5 \\
\hline Cocoa Ocean Beach Tracking Annex & $\mathrm{FL}$ & AF Active & 0.61 & 0.61 & 200,492 & 6,396 & 11,110 & 10 & 2 & 9.5 \\
\hline Mesonet \#0300 Weather Annex & $\mathrm{FL}$ & AF Active & 0.61 & 0.61 & 200,492 & 2,945 & 4,897 & 9 & 2 & 9.5 \\
\hline
\end{tabular}

Table E-12. Scoring for U.S. Air Force Sites with High Potential for Wave Energy MHK Projects at 1-mile Radius

\begin{tabular}{|c|c|c|c|c|c|c|c|c|c|c|c|}
\hline Base Name & State & DOD Branch & $\begin{array}{c}\text { Area-weighted } \\
\text { Mean TCS >0.6 } \\
\text { m/s to } 150 \mathrm{~m} \\
\text { Depth }\end{array}$ & $\begin{array}{c}\text { Maximum } \\
\text { TCS }>0.6 \mathrm{~m} / \mathrm{s} \\
\text { to } 150 \mathrm{~m} \\
\text { Depth }\end{array}$ & \begin{tabular}{|c|} 
Area with \\
TCS $>0.6 \mathrm{~m} / \mathrm{s}$ \\
to $150 \mathrm{~m}$ \\
Depth
\end{tabular} & $\begin{array}{c}\text { Distance to Area } \\
\mathrm{w} / \mathrm{TCS}>0.6 \mathrm{~m} / \mathrm{s} \\
\text { to } 150 \mathrm{~m}\end{array}$ & $\begin{array}{c}\text { Distance } \\
\text { to Sub- } \\
\text { station }\end{array}$ & $\begin{array}{l}\text { Total } \\
\text { Exclu- } \\
\text { sions }\end{array}$ & $\begin{array}{c}\text { Electric } \\
\text { Load }\end{array}$ & $\begin{array}{l}\text { Cost of } \\
\text { Elec- } \\
\text { tricity }\end{array}$ & $\begin{array}{l}\text { Total } \\
\text { Points }\end{array}$ \\
\hline Name & ST & DOD & (pts) & (pts) & (pts) & (pts) & (pts) & (pts) & (pts) & (pts) & (pts) \\
\hline Fort Richardson & $\mathrm{AK}$ & AF Active & 3.5 & 5.0 & 10.0 & 10.0 & 9.8 & 0.0 & 10.0 & 4.4 & 52.6 \\
\hline Eglin AFB & $\mathrm{FL}$ & AF Active & 2.6 & 3.0 & 10.0 & 10.0 & 0.1 & 10.0 & 10.0 & 1.9 & 47.6 \\
\hline Cape Cod AS & MA & AF Active & 2.8 & 4.0 & 10.0 & 7.0 & 0.0 & 10.0 & 7.9 & 3.2 & 44.8 \\
\hline Ipswich Antenna Farm Annex & MA & AF Active & 2.6 & 4.0 & 10.0 & 9.9 & 3.5 & 8.0 & 3.2 & 3.2 & 44.4 \\
\hline Elmendorf AFB & $\mathrm{AK}$ & AF Active & 3.5 & 5.0 & 10.0 & 10.0 & 0.8 & 0.0 & 10.0 & 3.5 & 42.7 \\
\hline Cudjoe Key AFS & $\mathrm{FL}$ & AF Active & 2.6 & 4.0 & 10.0 & 2.8 & 8.0 & 8.0 & 3.2 & 1.9 & 40.4 \\
\hline Cape Newenham Long Range Radar Site & AK & AF Active & 3.5 & 5.0 & 10.0 & 0.0 & 0.0 & 10.0 & 5.9 & 3.5 & 37.9 \\
\hline Newington Defense Fuel Support Point & $\mathrm{NH}$ & AF Active & 3.9 & 5.0 & 10.0 & 10.0 & 0.0 & 0.0 & 3.2 & 3.0 & 35.2 \\
\hline MacDill AFB & $\mathrm{FL}$ & AF Active & 2.0 & 1.0 & 7.0 & 0.0 & 6.9 & 6.0 & 10.0 & 1.9 & 34.8 \\
\hline Cape Canaveral AFS & $\mathrm{FL}$ & AF Active & 2.1 & 1.0 & 7.6 & 9.8 & 1.9 & 0.0 & 10.0 & 1.9 & 34.2 \\
\hline Naknek Recreation Annex \#2 & AK & AF Active & 2.6 & 4.0 & 10.0 & 0.0 & 0.0 & 10.0 & 3.2 & 3.5 & 33.3 \\
\hline Ship Shoal Island & VA & AF Active & 2.3 & 3.0 & 10.0 & 2.6 & 3.8 & 6.0 & 3.2 & 1.6 & 32.6 \\
\hline LWTC, NFAC Site \#1 & $\mathrm{CA}$ & AF Active & 2.6 & 1.0 & 7.1 & 0.0 & 8.3 & 6.0 & 4.4 & 3.1 & 32.5 \\
\hline Port Heiden Radio Relay Site & AK & AF Active & 3.0 & 4.0 & 10.0 & 0.0 & 0.8 & 8.0 & 3.2 & 3.5 & 32.5 \\
\hline Hurlburt Field & $\mathrm{FL}$ & AF Active & 2.3 & 1.0 & 3.9 & 0.0 & 10.0 & 8.0 & 5.3 & 1.9 & 32.4 \\
\hline Sagamore Hill Electronics Research Annex & MA & AF Active & 2.4 & 2.0 & 10.0 & 0.0 & 0.0 & 10.0 & 3.2 & 3.2 & 30.8 \\
\hline Clausen Missile Tracking Annex & $\mathrm{FL}$ & AF Active & 2.6 & 3.0 & 10.0 & 0.0 & 0.0 & 8.0 & 3.2 & 1.9 & 28.7 \\
\hline Onizuka AFB & CA & AF Active & 2.6 & 1.0 & 7.1 & 0.0 & 0.0 & 6.0 & 3.2 & 3.1 & 23.0 \\
\hline Port Canaveral Cable Terminal Annex & $\mathrm{FL}$ & AF Active & 2.1 & 1.0 & 7.6 & 4.9 & 0.0 & 0.0 & 3.2 & 1.9 & 20.7 \\
\hline Tel 4 Area Located On Kennedy Space Ctr & $\mathrm{FL}$ & AF Active & 2.1 & 1.0 & 7.6 & 0.0 & 0.4 & 0.0 & 3.2 & 1.9 & 16.2 \\
\hline Cocoa Ocean Beach Tracking Annex & $\mathrm{FL}$ & AF Active & 2.1 & 1.0 & 7.6 & 0.0 & 0.0 & 0.0 & 3.2 & 1.9 & 15.8 \\
\hline Mesonet \#0300 Weather Annex & $\mathrm{FL}$ & AF Active & 2.1 & 1.0 & 7.6 & 0.0 & 0.0 & 0.0 & 3.2 & 1.9 & 15.8 \\
\hline
\end{tabular}

